\title{
Essays on the impacts of climate-smart agricultural innovations on household welfare
}

Citation for published version (APA):

Tesfaye, W. M. (2019). Essays on the impacts of climate-smart agricultural innovations on household welfare. [Doctoral Thesis, Maastricht University]. Datawyse / Universitaire Pers Maastricht. https://doi.org/10.26481/dis.20190327wt

Document status and date:

Published: 01/01/2019

DOI:

10.26481/dis.20190327wt

Document Version:

Publisher's PDF, also known as Version of record

\section{Please check the document version of this publication:}

- A submitted manuscript is the version of the article upon submission and before peer-review. There can be important differences between the submitted version and the official published version of record.

People interested in the research are advised to contact the author for the final version of the publication, or visit the DOI to the publisher's website.

- The final author version and the galley proof are versions of the publication after peer review.

- The final published version features the final layout of the paper including the volume, issue and page numbers.

Link to publication

\footnotetext{
General rights rights.

- You may freely distribute the URL identifying the publication in the public portal. please follow below link for the End User Agreement:

www.umlib.nl/taverne-license

Take down policy

If you believe that this document breaches copyright please contact us at:

repository@maastrichtuniversity.nl

providing details and we will investigate your claim.
}

Copyright and moral rights for the publications made accessible in the public portal are retained by the authors and/or other copyright owners and it is a condition of accessing publications that users recognise and abide by the legal requirements associated with these

- Users may download and print one copy of any publication from the public portal for the purpose of private study or research.

- You may not further distribute the material or use it for any profit-making activity or commercial gain

If the publication is distributed under the terms of Article $25 \mathrm{fa}$ of the Dutch Copyright Act, indicated by the "Taverne" license above, 


\section{Essays on the Impacts \\ of Climate-Smart Agricultural \\ Innovations on Household Welfare}

Wondimagegn Mesfin Tesfaye 
Printing: Datawyse - Universitaire Pers - Maastricht ISBN 9789463802253

Copyright (C2019 by W.M. Tesfaye

All rights reserved. No part of this publication may be reproduced or utilized, stored in a retrieval system, or transmitted in any form, or by any means, electronic, mechanical, photocopying, recording or otherwise, without the prior permission of the author.

Cover design: Ubbo Noordhof 


\section{Essays on the Impacts of Climate-Smart Agricultural Innovations on Household Welfare}

\section{DISSERTATION}

to obtain the degree of Doctor at Maastricht University, on the authority of the Rector Magnificus Prof. R.M. Letschert, in accordance with the decision of the Board of Deans, to be defended in public on Wednesday 27 March 2019, at 10:0o hours

by

Wondimagegn Mesfin Tesfaye 
SUPERVISORS:

Prof. Dr. Théophile Azomahou

Dr. Nyasha Tirivayi

ASSESSMENT COMMitTeE:

Prof. Dr. Pierre Mohnen (Chairman)

Prof. Alban Ahoure, University Felix Houphouet Boigny, Côte d'Ivoire

Prof. Dr. Franziska Gassmann

Dr. Maty Konte

Prof. Phu Nguyen-Van, CNRS and Université de Strasbourg, France 
This dissertation provides empirical evidence on the risk management and welfare effects of selected climate-smart land and crop management innovations in Sub-Saharan Africa (SSA). The dissertation comprises five chapters. The introductory chapter highlights the repercussions of climate change, soil degradation, post-harvest loss and population swells on the present and long-term development prospect of SSA. It also highlights the shift in the current agricultural policy focus towards increased promotion of climate-smart agricultural innovations as a way forward to spur agricultural growth in the face of environmental risks. The three chapters investigate whether climate-smart agricultural technologies and practices have the potential to enhance food and nutrition security, adaptive capacity and protect rural households from continuously sliding into poverty.

Chapter 2 provides microeconomic evidence on the household welfare effect of conservation agriculture (CA), a climate-smart agricultural practice currently receiving an increasing attention in SSA. The chapter focuses on the analysis of the impact of CA on household poverty in Ethiopia using panel survey data merged with novel weather data. The empirical strategy presented is a panel data switching regression model applied in a polychotomous CA technology choice setting that helps to account for farmer heterogeneity in the CA choice. The results indicate that minimum tillage, cereal-legume intercropping and their combination are the CA practices that reduce rural poverty. Disaggregating the results by rainfall endowment and wealth groups, we find evidence that the combination of minimum tillage and cereal-legume intercropping provides better welfare benefits in most circumstances. However, crop residue retention and its combined use with minimum tillage do not seem to be attractive. While the evidence suggests that CA plays a crucial role in dealing with the exigencies of being poor and mitigates production risks, we caution against exaggerated expectations of CA's economic benefits and a rigid recommendation of CA.

In the wake of climate change, there is a resurgence of interest in the promotion of crop diversification as a climate-smart agricultural practice in SSA. Crop diversity comes as a natural insurance mechanism to safeguard farmers from the adverse effects of shocks. Using rich panel survey data merged with historical rainfall data, chapter 3 sheds light on the household welfare and consumption smoothing effects of crop diversity in rural Uganda. The chapter contributes to emerging development economics literature that links diversity with household welfare. The empirical analysis is supported by panel data instrumental variables methods. The response of consumption to crop diversity for low- and high-consuming households is also estimated using 
quantile regression instrumental variables methods. The results show that increasing crop diversity contributes to increased consumption and diverse diets. Crop diversification provides higher consumption benefits for households in the lower quantile of the consumption distribution than for households at higher quantiles, indication of its non-linear and heterogeneous consumption effect. Increased crop diversification also improves consumption smoothing through reducing households' reliance on less effective risk coping strategies such as informal insurance. Overall, the findings suggest that transforming agriculture towards a more diversified cropping system could be a viable pathway for improving household nutrition and reducing poverty.

Chapter 4 focuses on the analysis of the impact of improved storage technologies on household food and nutrition security, consumption expenditure and child growth in Ethiopia. Using endogenous switching regression models to control for unobserved and observed heterogeneity between improved storage users and non-users, we find evidence that use of improved storage technologies increases dietary diversity, reduces the risk of stunted growth for children under 5 years of age and lessens self-reported food insecurity. More important, the model results show that nonuser households would have experienced these benefits had they used improved storage technologies. The chapter contributes to the agricultural innovation adoption and impact literature that seems to be overly focused on preharvest and production.

Chapter 5 concludes with policy implications and suggestions for further research. 


\section{ACKNOWLEDGEMENTS}

The completion of this work would not have been easier without the great friends, excellent mentors and colleagues who have been part of my life during the Ph.D. journey. This dissertation is the result of many experiences I have encountered at UNU-MERIT and elsewhere from many remarkable individuals whom I wish to acknowledge.

First and foremost, I would like to express my sincere gratitude to my supervisors Prof. Théophile Azomahou and Dr. Nyasha Tirivayi. I am indebted to Théo for his continuous support since the beginning of my Ph.D. study and research. His patience, motivation, enthusiasm, inspiration and immense knowledge have shaped my research. It has truly been an honour and a privilege working with him. A special mention goes to Nyasha who has provided priceless personal and professional support, guidance and countless insightful suggestions that made this work possible. Without her wonderful supervision, I would not have been able to develop the skills required to complete this work. She has always been available to support me despite her charged schedule. Her relentless support and encouragement to follow my own ideas allow me to grow as a researcher. I will remain indebted to her throughout my career. Special thanks go to Prof. dr. Pierre Mohnen, Prof. Alban Ahoure, Prof. dr. Franziska Gassmann, Dr. Maty Konte and Prof. Phu Nguyen-Van for serving on my PhD committee. I am incredibly thankful for the time and effort they have exerted to read the dissertation and forward brilliant comments, insightful suggestions and questions.

I would like to express my gratitude to UNU-MERIT for the financial support and for providing a wonderful academic environment. I am grateful to the academic and research staff at UNU-MERIT who have provided a model of professional scholarship that I would be lucky to emulate. A special appreciation goes to Eveline who has always been supportive and a source of love and energy ever since I came to UNUMERIT. A warm thanks go to Herman, Sueli, Marc, Ingeborg, and other supportive staff of UNU-MERIT.

I would like to give a special credit to Cornell University for offering me the STAARS 2017 fellowship opportunity. I have to thank Garrick Blalock (my STAARS mentor), Chris Barrett and Liz Bageant for their intellectual contribution to my work and administrative support during my visit to Cornell. I received a special support from Prof. Futoshi Yamuachi (IFPRI) and Dr. Paswel Marenya (CIMMYT). At this juncture, I would like to pass my heartfelt thanks to colleagues at Haramaya University, where the most basic source of my passion for my area of specialization begins.

There are a lot of people who deserve to be thanked for making my time at Maastricht more joyful than I had ever anticipated. My stay at UNU-MERIT has been en- 
riched by the friendship of my classmates: Bruhan, Mario, Cho, Hugo, Davina, Eli, Francesca, Fernando, Janyl, Nga, Arip, Maria, and Nora. I would like to pass my earnest appreciation to my wonderful friends Alex and Francesco. I would not forget the terrific, adventurous and funny moments we have had in Maastricht, Kenya and Malawi. I really enjoyed the companionship of Ibrahima, Iman, Elvis, Racky, Lika, Cristina, Tobias, Gideon, Rumbi, Danilo, Ajay, Sonila and other MERIT friends who created an enriching community of scholars.

I would like to extend my heartfelt gratitude to senior Ethiopian friends from UNUMERIT and Maastricht University. I owe a very important debt to Hibret whose kindness and motivation always amaze me. I am deeply grateful to Tigist, Hassen, Eleni, Hayelom and Yesuf who have made my time at Maastricht wonderful. Special words of gratitude go to Ethiopian friends in Maastricht: Kaleab, Jemal, Hiwot, Halefom, Aderajew, Musa, Mulu and Eskedar. My time in Maastricht would not have been the same without their companion and support, particularly in this tremendously solitaire process. I would like to thank Genet, Eskinder, Tomas and Tsegay for making my stay in Maastricht memorable. I am very lucky to have caring and supportive friends in Ethiopia and other corners of the globe: Tadiwos, Essete, Gebrelibanos, Yohannes, Yibekal, Chane, Gemoraw, Alelign, Bruhtesfa, Fresenbet, Gigi, Lemma, Mequanint, Abule, Aemro, Belayneh, Million, Mahlet and others.

My immense and eternal gratitude is due for my family for their unconditional support and love. I remain grateful to my parents: my later father Mesfin Tesfaye who has also been my role model, and my late mother Workie Zewdie. Their neverwavering encouragement and never-ending belief in me has enabled me to pursue my passion and kept me going each time my doubts began to overwhelm me. Thanks to my brothers (Asnake and Asaminew) and sisters (Miskir and Zewditu) who are source of my smile and reason to live. I would like to thank members of the extended family for their support and encouraging moments. This dissertation is dedicated to my family and those who stood by my side when I was at my lowest and made me stand here stronger.

Last but not least, I want to praise the almighty God who gave me the opportunity to live, and the courage to overcome many hurdles. I keep asking him to bless me with gratitude that unlocks the fullness of life.

"Whoever gathered much had nothing left over, and whoever gathered little had no lack." 


\section{CONTENTS}

$1 \quad$ INTRODUCTION 1

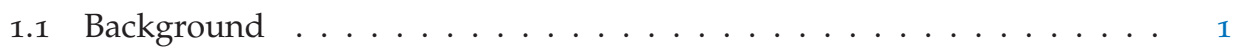

1.2 Research Questions . . . . . . . . . . . . . . . . . 5

1.3 Study Countries and Data . . . . . . . . . . . . . 6

1.4 Theoretical Foundations and Impact Pathways . . . . . . . . . . . . 7

1.4.1 Conceptual framework . . . . . . . . . . . . . 8

1.4 .2 Impact pathways . . . . . . . . . . . . . . . . . 9

1.5 Structure of the Dissertation . . . . . . . . . . . . . II

Bibliography 14

2 CONSERVATION Agriculture ANd POVERTy in RURAL Ethiopia 23

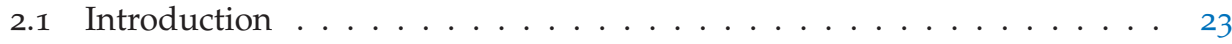

2.2 Country Context and CA Promotion . . . . . . . . . . . . . 26

2.3 Theoretical Framework . . . . . . . . . . . . . . . . 28

2.4 Empirical Strategy . . . . . . . . . . . . . . . . . . 30

2.5 Data and Descriptive Statistics . . . . . . . . . . . . . . . 36

2.5.1 Household and Rainfall Data . . . . . . . . . . . . . . . . 36

2.5.2 Conservation agriculture use pattern . . . . . . . . . . 37

2.5 .3 Household poverty . . . . . . . . . . . . . . 40

2.5.4 Mechanisms - farm level economic outcomes . . . . . . . . . . 41

2.6 Econometric Results . . . . . . . . . . . . . . . . . . . . 43

2.6.1 Drivers of CA use . . . . . . . . . . . . . . . . . 43

2.6.2 Impacts of CA on Poverty . . . . . . . . . . . . . . 45

2.6 .3 Impact Pathways . . . . . . . . . . . . . . . . . . . . . . 48

2.7 Conclusion ........................... 50

Bibliography $\quad 52$

$\begin{array}{ll}\text { A APPENDIX } & 61\end{array}$

3 CROP DIVERSITY, WELFARE AND CONSUMPTION SMOOTHING UNDER RISK IN RURAL UGANDA 81

3.1 Introduction $\ldots \ldots \ldots \ldots$ 81

3.2 Country Context . . . . . . . . . . . . . . . . . 83

$3 \cdot 3$ Theoretical Framework . . . . . . . . . . . . . . 84

3.3.1 Economics of crop diversification . . . . . . . . . . . . . . 84

3.3.2 Linking crop diversity with welfare and risk coping . . . . . . 85 
$3 \cdot 3 \cdot 3$ Impact pathways . . . . . . . . . . . . . 86

3.4 Empirical Strategy . . . . . . . . . . . . . . . . . . 88

3.4.1 Drivers of crop diversification . . . . . . . . . . . 88

3.4.2 Strategies for estimating the impact of crop diversification . . . . 89

3.5 Data and Descriptive Statistics . . . . . . . . . . . . . . . . 94

3.5.1 Household Survey and Rainfall Data . . . . . . . . . . . . . . . . 94

3.5.2 Crop diversification measures and patterns . . . . . . . . . . . . 95

3.5 .3 Household welfare and risk coping . . . . . . . . . . . . . 96

3.6 Results and Discussions . . . . . . . . . . . . . . . . . 98

3.6.1 Drivers of crop diversification . . . . . . . . . . . . . . . . 98

3.6.2 Welfare effects of crop diversification ............ 100

3.6.3 Crop diversification and risk coping . . . . . . . . . . . . 104

3.7 Conclusion . . . . . . . . . . . . . . . . 106

$\begin{array}{ll}\text { Bibliography } & 107\end{array}$

B APPENDIX $r$

4 FOOD STORAGE INNOVATIONS, FOOD SECURITY AND WELFARE IN ETHIOPIAI3I

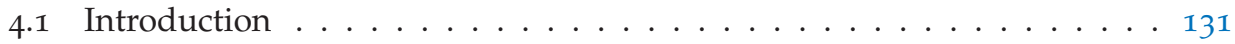

4.2 Methodology . . . . . . . . . . . . . . . 134

4.2.1 Conceptual framework . . . . . . . . . . . . . . . . 134

4.2.2 Estimation strategy . . . . . . . . . . . . . . 135

4.3 Data and Descriptive Statistics . . . . . . . . . . . . . . . . . . . . . . . .

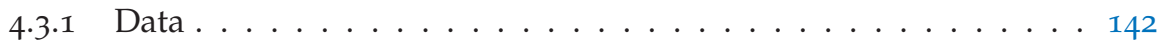

4.3.2 Variables and descriptive statistics . . . . . . . . . . . . . 143

4.4 Results and Discussion . . . . . . . . . . . . . . . . . . 147

4.4.1 Drivers of improved storage technology use . . . . . . . . . . . 147

4.4.2 Endogenous switching regression results . . . . . . . . . . . . . 149

4.4.3 Comparing results across various estimation methods . . . . . 153

4.5 Conclusion . . . . . . . . . . . . . . . . . . 154

Bibliography $\quad 155$

$\begin{array}{ll}\text { C APPENDIX } & 163\end{array}$

5 SYNTHESIS 171

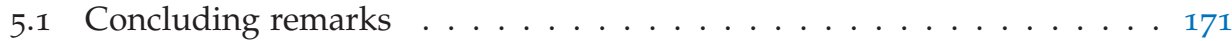

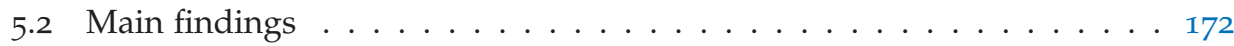

5.3 Policy recommendations . . . . . . . . . . . . . . . . . 174

5.4 Study limitations . . . . . . . . . . . . . . . . . . 176

5.5 Areas for future research . . . . . . . . . . . . 176 


\section{LIST OF FIGURES}

Figure 1.1 Safe operating space: Link between climate change, agriculture and food security . . . . . . . . . . . . . . 4

Figure C.1 Common support conditions . . . . . . . . . . . . 169 
Table 2.1

Table 2.2

Table 2.3

Table 2.4

Table 2.5

Table 2.6

Table 2.7

Table A.1

Table A.2

Table A.3

Table A.4

Table A.5

Table A.6

Table A.7

Table A.8

Table A.9

Table A.1o

Table A.I1

Table A.12

Table A.13

Table A.14

Table 3.1

Table 3.2

Table $3 \cdot 3$

Table $3 \cdot 4$

Table $3 \cdot 5$

Table 3.6

Table 3.7

Table B.I

Table B.2

Table B.3

Table B.4
Pattern of CA combinations adoption (\%) . . . . . . . . 38

Household welfare and farm household level economic outcomes by CA set . . . . . . . . . . . . . . . . . . . . . . . 42

Impact of CA on household poverty . . . . . . . . . . . . 45

Effects of CA on poverty headcount by rainfall and household wealth . . . . . . . . . . . . . . . . . . . . . 47

Impact of CA on crop income per hectare . . . . . . . . . . . 48

Impact of CA on cost of production . . . . . . . . . . . . . . . 49

Impact of CA on risk of crop failure $\ldots \ldots \ldots 50$

Proportions of households practicing CA $(\%) \ldots . . . . .661$

Transitions in CA use over the sample periods 2013 and $2015(\%) 62$

Household characteristics by CA sets . . . . . . . . . . . . . 62

Drivers of CA use: Marginal effects . . . . . . . . . . . . . . . . . 64

Poverty headcount equation estimates . . . . . . . . . . . . . . 66

Poverty gap equation estimates . . . . . . . . . . . . . . . . . 68

Poverty severity equation estimates . . . . . . . . . 70

Estimates of net crop income equations . . . . . . . . . . 72

Estimates of cost of production equations . . . . . . . . . 74

Estimates of risk of crop failure equations . . . . . . . . . 76

Test on validity of the exclusion restrictions . . . . . . . . 78

Impact of CA on poverty headcount, gap and severity $\ldots . . .79$

Distributional effects of CA on poverty incidence (headcount)

by rainfall and household wealth . . . . . . . . . . . 80

Impact of CA on crop income, production cost and risk of crop

failure ..................... . . 80

Summary statistics for crop diversity pattern over the study years 96

Summary statistics of the outcome variables . . . . . . . . 97

Drivers of crop diversity: Estimates from Panel Correlated Ran-

dom Effects . . . . . . . . . . . . . . . . . . . . 99

Effects of crop diversity on aggregate household dietary diversityı1 Effects of crop diversity on consumption expenditure . . . . . 103

Welfare effects of crop diversity: quantile regression estimates . 104 Impact of crop diversity on risk coping . . . . . . . . . . . 105

Calculation of crop diversification indices . . . . . . . . . . 116

Summary statistics for variables used in the analysis . . . . . . 117

Effect of crop diversity on dietary diversity: FE-IV estimates . . 118

Effects of crop diversity on dietary diversity: 2SRI estimates . . 119 
Table B.5 Effects of crop diversity on consumption expenditure: FE-IV estimates . . . . . . . . . . . . . . . . 120

Table B.6 Consumption expenditure effects of crop diversity: 2SRI estimates121 Table B.7 Welfare effects of crop diversity (Count index): Quantile regression estimates . . . . . . . . . . . . . . . . . 122

Table B.8 Welfare effects of crop diversity (Shannon-Weaver): Quantile regression estimates . . . . . . . . . . . . . . . . . 123

Table B.9 Welfare effects of crop diversity (Composite entropy): Quantile regression estimates . . . . . . . . . . . . . . . . . 124

Table B.10 Welfare effects of crop diversity (Berger-Parker): Quantile regression estimates . . . . . . . . . . . . . . . 125

Table B.11 Effects of crop diversity on informal insurance: FE-IV estimates 126 Table B.12 Effects of crop diversity on involuntary diet change: FE-IV estimates . . . . . . . . . . . . . . . . . . . . 127

Table B.13 Crop diversity and welfare: Estimates from balanced panel . . . 128

Table B.14

Table $4 \cdot 1$

Table 4.2

Table $4 \cdot 3$

Crop diversity and risk coping: Estimates from balanced panel . 129

Conditional expectations, treatment effects, and heterogeneous

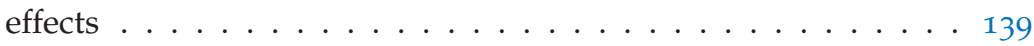

Food storage methods used by sample households . . . . . . . 144

Summary statistics of food security and welfare of the sample households . . . . . . . . . . . . . . . 146

Table 4.4 Endogenous switching regression based treatment effects . . 150

Table 4.5 Treatment effects: Endogenous switching probit estimates . . 153

Table $4.6 \quad$ Comparing results from alternative specifications (ATT) . . . . 154

Table C.1 Description and summary statistics of the main explanatory variables . . . . . . . . . . . . . . . . 163

Table C.2 Drivers of improved storage technology use . . . . . . . . . . 164

Table C.3 Endogenous Switching Regression estimation . . . . . . . . . 165

Table C.4 Switching probit estimation (selected outcomes) . . . . . . . . 167

Table C.5 Test on the validity of the selection instrument (parameter estimates) . . . . . . . . . . . . . . . . . . . 168

Table C.6 Additional tests for the exclusion restriction $\ldots \ldots \ldots$. . . 168

Table C.7 Matching quality test . . . . . . . . . . . . . . 169

Table C.8 Sensitivity analysis: Rosenbaum bounds (rbounds) and Mantel-

Haenszel $(\mathrm{MH})$ bounds . . . . . . . . . . . . . . . . . . 169 



\section{I}

INTRODUCTION

\subsection{BACKGROUND}

Recent evidence has pointed to a rise in global hunger and food insecurity (FAO et al., 2018). The challenges are nowhere more severe than in Sub-Saharan Africa (SSA), a region that confronts a food crisis with many dimensions including hunger and high tolls of child malnutrition (Gatzweiler and Von Braun, 2016). There is also evidence of significant interregional disparities in the prevalence of food insecurity (about 30\% in Africa) and the progress towards reducing poverty and child stunting. SSA has seen the least progress in terms of relative improvement by most standards. For instance, it continues to see an upward trend in the number of stunted children, whereas other regions (e.g., Asia) have experienced the largest relative decrease in the prevalence of stunting (FAO et al., 2018). Over and above, food insecurity and rural poverty remain pressing development concerns in SSA (Majiwa et al., 2018; Suri, 2011). Countries in the region at high risk of food insecurity and poverty are those in which the livelihood of a high proportion of the population depends on agriculture.

Due to the sheer number of people who depend on agriculture for their livelihood (Davis et al., 2017), increasing agricultural productivity is considered to be an important stepping stone out of poverty for the rural poor (Bachewe et al., 2017; Christiaensen and Demery, 2007; Christiaensen et al., 2011). Likewise, agriculture is uniquely positioned as a tool to attain the 2030 Sustainable Development Goals (SDG) of the United Nations targeted at reducing poverty, ending hunger, achieving food and nutrition security and promoting sustainable agriculture (FAO, 2016). Despite this enthusiasm, the sector continues to underperform in much of SSA, a region where agricultural productivity is low and production is variable (van Ittersum et al., 2016). This also leads to a debate on the sector's contemporary role in development despite its contribution to poverty and hunger reduction in developing countries (Hazell et al., 2010). Amongst the threats to agricultural productivity in SSA are farmers' reliance on unsustainable farming practices (Grabowski et al., 2016; Marenya and Barrett, 2009; Tittonell and Giller, 2013) and climate variability and extremes.

Climate variability and extremes bring numerous risks to agricultural production, and impede economic growth and sustainable development (Di Falco et al., 2011; Lobell et al., 2008; Nyasimi et al., 2014; Wood et al., 2014). Although not the single factor, 
they are important drivers behind the recent uptick in undernourishment, hunger, and food insecurity (FAO et al., 2018). They have the strongest direct impact on food availability through their adverse effect on agricultural productivity, food production and cropping patterns. Climate shocks that include the occurrence of extreme rainfall and/or temperatures or complex events such as droughts are important sources of low agricultural productivity and income volatility (Di Falco and Chavas, 2009; Di Falco et al., 2011; Castells-Quintana et al., 2018). For instance, highly erratic rainfall patterns and rising temperatures turn the production decisions of farmers into a repeated gamble to the extent that they are unable to predict the ideal conditions to plant their crops (Frankema, 2014). Future projections warn that erratic rainfall and increasing temperatures are likely to reduce agricultural yield for major food crops and cereal productivity levels in SSA (Cline, 2008). The resulting productivity decline will compound the stubbornly high levels of poverty and food insecurity in rural areas of SSA (Barrett et al., 2017; Jayne et al., 2018; Masters et al., 2018). Without adaptation, the impact of climate change on crop production in the region is expected to worsen as temperatures increase and become more extreme (IPCC, 2014). In addition to their direct effects, climate variability and extremes indirectly exacerbate the immediate and underlying causes of food insecurity, malnutrition and poverty (FAO et al., 2018). Beyond causing short-term income and consumption fluctuations, climatic shocks can have long-lasting impact on household well-being by pushing them into poverty traps (Dercon, 2004; Dercon and Christiaensen, 2011).

Although the impacts of climate change on agriculture and food security are global, the negative impacts are more pronounced in rural areas of developing countries that largely depend on rain-fed agriculture (Castells-Quintana et al., 2018). These are the same areas that already exhibit high rates of hunger and poverty due to their dependence on rain-fed agriculture, poor access to markets and weak adaptive capacity (IPCC, 2014). Farming households operating in these areas are most affected due to their vulnerability to weather-related shocks (de Janvry and Sadoulet, 2011) and lack of resources to cope with or adapt to their effects (Wheeler and Von Braun, 2013). Their vulnerability and weak adaptive capacity are attributed to the availability of fewer adaptive options (Brown and Funk, 2008), weak institutions, poor public infrastructure, limited access to information on climate-smart innovations (Asfaw et al., 2018) and declining soil fertility (Godfray et al., 2010; Sanchez, 2002). Climate change is anticipated to widen the gap between developed and developing countries because the latter suffer more the negative consequences due to their vulnerability and lack of adaptive capacity (IPCC, 2014). Moreover, it is expected to deepen intra-African disparities and aggravate migration (Frankema, 2014; Castells-Quintana et al., 2018).

In addition to the vagaries of climate variability and extremes, soil degradation and reduced biodiversity are cited to be main constraints to agricultural productivity and long-term growth prospects in SSA (Godfray et al., 2010; FAO, 2013; Juma et al., 2013). The main reasons for soil degradation are inefficient production methods, which cause 
a loss of soil carbon and soil fertility decline. The farming systems in SSA are characterised by low levels of soil carbon or organic matter, highly weathered soils and high rates of nutrient depletion. Low levels of soil organic matter lead to less capacity for soils to hold nutrients and moisture stress (Winterbottom et al., 2013). It also reduces fertiliser uptake and fertiliser use efficiency that potentially contribute to low agricultural productivity growth. Low crop yields, land degradation, loss of soil fertility and periodic drought are perhaps the major contributors to hunger and poverty among smallholder farmers in SSA. Through its adverse effects on livelihood and agricultural productivity, soil degradation could drag poor households into poverty trap (Asfaw et al., 2016; Dercon and Christiaensen, 2011; Dzanku et al., 2015). As part of the solution to this problem, farmers will need to abandon practices that contribute to soil degradation (Winterbottom et al., 2013).

Postharvest loss of crops presents another significant challenge for food security. Postharvest losses create food production inefficiencies, deforestation and potential global warming (Affognon et al., 2015; Lybbert and Sumner, 2012). Estimates show that about one-third of global food production is lost after harvest with the figure ranging from $20-60 \%$ (Tefera et al., 2011). The value of postharvest loss in SSA is estimated to be enough to feed nearly 48 million people and reduce the demand for cereal imports (Juma et al., 2013; Stathers et al., 2013). The major reasons for postharvest loss in SSA include low levels of improved storage technologies, poor infrastructure, weak institutions, limited knowledge and other managerial and technical constraints (FAO et al., 2018). Moreover, climate fluctuation and climate change events such as increasing temperatures and humidity harm post-harvest aspects. Given low crop production in SSA, postharvest loss will exacerbate food insecurity, hunger, and rural poverty.

Amidst the aforementioned challenges, the world population is expected to soar from its current level of about 7 billion to 10 billion by 2050, of which, about onefifth is expected to happen in SSA. Although the large population expansion in SSA is not a problem by itself, its speed and timing are already putting unprecedented pressure on the agricultural sector and the adaptive capacity of societies (Gatzweiler and Von Braun, 2016; Jayne et al., 2018). The increase in population is accompanied by a disproportionate increase in demand for food (FAO, 2011; United Nations, 2009). In SSA, agricultural output would need to more than double by 2050 to meet the increased demand. Under current land management practices, population growth predictions, and present production and consumption trends, the food production systems in SSA will meet only 13\% of the continent's food needs by 2050 (Juma et al., 2013). Due to the increasing challenges of climate change, rapid population growth, soil fertility decline and postharvest loss, agriculture in SSA faces significant challenges to increasing food production and feeding a growing population without significantly increasing the area under cultivation. How SSA can avert the Malthusian doom scenario is uncertain, especially in the face of a changing climate. This is 
a policy and development challenge far greater than what we faced during the Green Revolution (GR); (Gatzweiler and Von Braun, 2016).

While agricultural development through increasing agricultural productivity with the help of the GR inputs (e.g. chemical fertilizer) continues to play a crucial role, the multiple challenges of climate change and growing population demand new approaches to produce diverse and nutritious crops and mitigate the negative effects of agriculture on climate. Moreover, some argue that the GR technologies cause environmental risks, erode biodiversity, are costly and could leave the poor behind. This urges the need for a new paradigm shift in African agriculture that ensures inclusive climate change adaptations relying on grassroot innovations and farming practices (Godfray et al., 2010). Sustainable agricultural intensification, which entails increasing agricultural productivity on existing farmlands without adverse effects on the environment, is suggested to be the way forward to meet the food demand for the everincreasing population in SSA in the face of climate change (Frankema, 2014; Garnett et al., 2013; Godfray and Garnett, 2014; Pretty et al., 2011). The sustainable intensification paradigm is strongly linked with and enabled by climate-smart agriculture (CSA). Due to its capacity to unite the agendas of agriculture, development and climate change, CSA now dominates the current discussions in agricultural development (Arslan et al., 2017; FAO, 2013; Lipper et al., 2018).
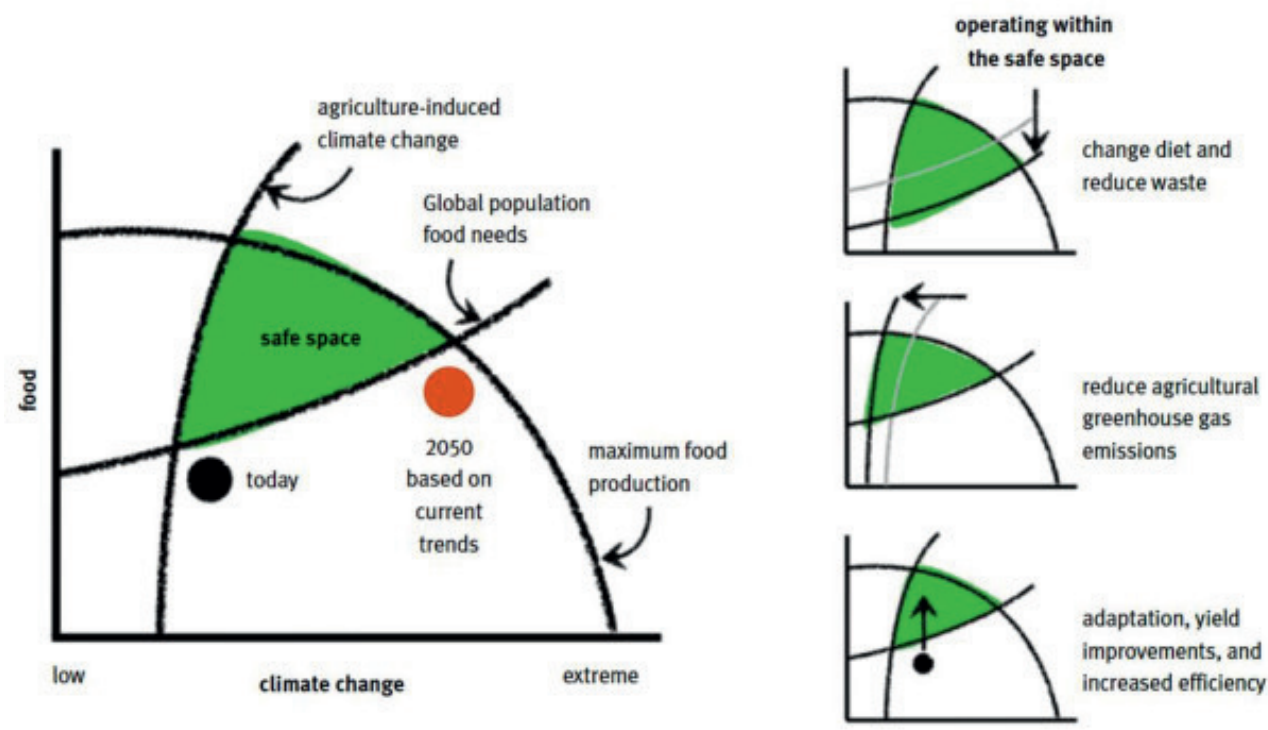

Figure 1.1: Safe operating space: Link between climate change, agriculture and food security Source: Beddington et al. (2012). 
As can be seen from figure 1.I (left panel), we are not currently operating in the safe space and that with present trends, we are likely to operate outside the safe space by 2050. Avenues to safe production space include the adoption of climate-smart agricultural practices that would reduce food loss (e.g. storage innovations), mitigate climate change (e.g. conservation agriculture), and climate change adaptation and yield improvements (e.g. crop diversification, conservation agriculture); (Beddington et al., 2012; Neufeldt et al., 2013; Rockström et al., 2009). Climate-smart technologies and practices would help farmers either to move towards the existing production possibilities frontier or push out the frontier of production possibilities (FAO, 2014). Through their potential to support sustainable agricultural productivity growth in the face of climate variability and extremes, these innovations are feasible options to "find the equilibrium and equity between the needs of the present and future generations" (Beuchelt and Badstue, 2013). The transition towards a climate-smart agriculture and food system is characterised by a technological approach that emphasises the role of opportunities and constraints of local ecologies and a political economy approach that focuses on incentive structures (Frankema, 2014; Saj et al., 2017).

Climate-smart agricultural innovations (technologies and practices) have the potential to sustainably increase agricultural productivity, mitigate environmental degradation, increase farmers' resilience and stimulate inclusive growth (FAO, 2010; United Nations, 2011). They hold a promise to bolster sustainable agricultural production to meet current and future food needs through reducing climate-induced risks, greenhouse gas emissions and postharvest loss (Foley et al., 2011; Godfray and Garnett, 2014; Frankema, 2014; Lobell et al., 2008).They also would help to increase the capacity of smallholder farmers to deal with low and unpredictable crop yields (Winterbottom et al., 2013), reduce the vulnerability of households and agricultural systems to climate change and enhance the adaptive and risk management capacities of households (Bradshaw et al., 2004). In addition to addressing the triple challenges of food security, adaptation, and mitigation, they serve as a bridge to other development goals. Increased adoption of climate-smart agricultural innovations could be one of the strategies to improve human nutrition, conquer poverty and hunger, and promote long-term inclusive growth in SSA without jeopardizing the needs of future generations. Thus, they could be important drivers of the progress towards the triumph of the SDGs 1 and 2 (poverty and hunger reduction) and 7 (tackling the effects of climate change); (FAO et al., 2018). This dissertation aims to provide empirical evidence to justify this position.

\subsection{RESEARCH QUESTIONS}

The overarching objective of this dissertation is to investigate the risk management and welfare effects of selected climate-smart agricultural innovations in SSA with a focus on Ethiopia and Uganda. It provides empirical evidence that increases our 
understanding of the scale of adoption of the climate-smart technologies and practices as well as the drivers, opportunities and constraints associated with these innovations. Such evidence provides useful policy insights for CSA interventions.

The dissertation addressess the following key research questions:

1. What is the impact of conservation agriculture (CA) on rural poverty? Are the impacts heterogeneous with reference to differences in rainfall and resource endowments? (Chapter 2)

2. How does increasing crop diversity affect household consumption, aggregate household diets and risk coping behaviour? Does crop diversity generate heterogeneous consumption benefits for low-consuming (poor) and high-consuming (wealthy) households? (Chapter 3)

3. What are the food and nutrition security and welfare impacts of improved food storage techniques? (Chapter 4 )

\subsection{STUDY COUNTRIES AND DATA}

In this dissertation, the focus is on two countries in SSA: Ethiopia and Uganda. Located in eastern Africa, the countries share many of the development challenges in the region including climate change and variability (IPCC, 2014). Agriculture is the major employer and source of livelihood for the majority of the population in both countries. The sector is mainly rain-fed and thus vulnerable to rainfall and temperature variability. Unfavourable weather and climate conditions including the occurrence of drought, increasingly unreliable rainfall and gradually increasing temperatures are among the main challenges to achieving food security in eastern Africa. The impacts of climate variability and extremes on agricultural production are contributing to food and nutrition insecurity, poverty, migration, conflicts, and other challenges in the region. Both countries make positive strides to catch up after a long period of poor performance (Noguera-Santaella, 2017). Despite a remarkable progress in reducing hunger and malnutrition in the last two decades, the countries are among those with a precarious food security situation and prevalent rural poverty.

Among the climate-smart agricultural technologies and practices being promoted in the countries to improve productivity, food availability and resilience to climate shocks include crop diversification, conservation agriculture (rotations, intercropping, mulching, and reduced tillage) and postharvest loss mitigation techniques (FAO, 2013; Jirata et al., 2016). ${ }^{1}$ This dissertation aims to provide empirical evidence on the economic impacts of conservation agriculture, crop diversification and improved crop storage methods in the two countries.

1 See https://ccafs.cgiar.org/publications/climate-smart-agriculture-uganda.XCzTDixKjcs for Uganda and https://ccafs.cgiar.org/publications/climate-smart-agriculture-ethiopia.XCzUKFxKjcs for Ethiopia. 
Data for the dissertation (Chapters 2 and 4) primarily come from the Ethiopian Socioeconomic Survey (ESS). The ESS is a joint project between the World Bank Living Standards Measurement Study-Integrated Surveys on Agriculture (LSMS-ISA) and the Central Statistical Agency of Ethiopia. The ESS collects data in the periods 2011/12, 2013/14 and 2015/16. Uganda National Panel Survey (UNPS), which spans the period 2009/10 to 2011/12, is the other data set used in the dissertation (Chapter 3 ). Both surveys are nationally representative and collect panel data on household characteristics, consumption and food security, shocks and coping strategies, agricultural production and crop disposition patterns. The panel nature of the datasets helps us generate policy-relevant findings and important contributions to the literature. The households are also georeferenced. This allows merging the household survey data with weather data extracted from Climate Hazards Group InfraRed Precipitation with Station (CHIRPS).

The findings of the study will support policy actions to transform and reorient agricultural systems to support development and food and nutrition security effectively and sustainably under a changing climate. Ethiopia and Uganda are among the few African countries where initiatives are being made towards identifying suitable policy and institutional frameworks that support the uptake of CSA (Arslan et al., 2017; Jirata et al., 2016). Uganda, in particular, has made progress in integrating climate change into national development plans as well as agricultural policies and programmes. This includes the development of a national CSA framework programme, the launching of the agriculture sector's National Adaptation Plan (NAP) process, and the formulation of a national climate change policy (Arslan et al., 2017). Therefore, providing empirical evidence on the economic impacts of climate-smart agricultural technologies and farming practices will provide inputs for policy development and implementation. To this purpose, we provide evidence that will be important for policy makers in agriculture, environment and development to ensure emerging policies and strategies on climate change, agriculture and food security.

\subsection{THEORETICAL FOUNDATIONS AND IMPACT PATHWAYS}

Schumpeter (1939) is perhaps the first to define innovation in the academic literature in relation to an economic context (FAO, 2014). According to him, innovation is the introduction of a new production method or inputs into a production system. Innovation also includes a new good, a new attribute of an existing good or a new organizational method. Mirroring Schumpeter's definition, the Organisation for Economic Cooperation and Development (OECD) and Eurostat emphasize that innovation entails the implementation of a new or improved product, process, a new marketing approach or a new organizational method (OECD and Eurostat, 2005). World Bank (2010) defines innovation as technologies or practices that are being diffused to a given economy or society. This definition underlines that innovation embraces the 
use of existing knowledge and finding new solutions to existing problems that would eventually benefit the society.

This dissertation adopts a working definition of innovation specific to agriculture and that focuses on the impact on food and nutrition security, risk management, sustainable natural resources management and economic development outcomes (FAO, 2012, 2014). Drawing on this definition, climate-smart innovations include technologies and farming practices (e.g., new types of crops), farm production processes (e.g., conservation agriculture) and postharvest management (e.g., improved crop storage) that are diffused to improve farm productivity, climate change adaptation and mitigation. These innovations are diverse and range from farm-level techniques to international policy and finance mechanisms (Arslan et al., 2015). Climate-smart innovations in farming systems occur through developing, adapting and adopting new ideas, technologies and processes for the purpose of improving agricultural production and farm management (Juma et al., 2013; FAO, 2014). They involve complex processes with many actors that include farmers, extension and development agents, government, scientists, donor organizations, and private firms. Successful innovations often spread through communities and societies via various channels such as farmer-to-farmer extension, government extension, observations (farmers field days) and interventions. Furthering agricultural innovations requires an effective agricultural innovation system that includes enabling economic and institutional environment.

Among the prominent technological innovations that fall under Climate Smart Agriculture (CSA), this dissertation focuses on conservation agriculture, crop diversification and improved crop storage technologies. The primary reason for focusing on these innovations is their primacy in recent policy dialogues in SSA. We analyse the potential of these CSA technologies and practices in improving household welfare and risk management. We also investigate the drivers of farm households' decision to use these innovations with a focus on the role of climatic factors, household characteristics, and the institutional environment. Furthermore, we demonstrate the possible pathways through which the innovations would affect the different welfare and risk coping metrics.

\subsubsection{Conceptual framework}

The central focus of this dissertation is to establish the link between climate-smart innovations and food system outcomes. In the spirit of the sustainable livelihoods framework (SLF), farm households' decision to adopt climate-smart agricultural innovations could be influenced by livelihood assets (Asfaw et al., 2018; Beuchelt and Badstue, 2013). The livelihood assets include natural capital, human capital, physical capital, financial capital and social capital. The assets can be represented by a set of household demographic characteristics as well as infrastructural, farm, and 
biophysical characteristics (Asfaw et al., 2018; Beuchelt and Badstue, 2013). They influence households' preferences, labor availability, and liquidity constraints (Dercon, 1996; Feder et al., 1985; Rosenzweig and Binswanger, 1993). Thus, they determine households' vulnerability to climate change and related events, productivity gains and household welfare amongst rural smallholders (Gatzweiler and Von Braun, 2016; Asfaw et al., 2018).

Livelihood assets also interact with institutions, and influence households' adaptive capacity and well-being. Formal and informal institutions play an important role in affecting households' innovation and livelihoods. Their effect can be either enabling or inhibiting. They would affect innovation through their effect on facilitating access to markets, labor, and credit. They can also affect the preferences of households through shaping beliefs and values, which in turn affect their production, marketing, and consumption decisions (Beuchelt and Badstue, 2013). Other important determinants of farmers' decision to uptake climate-smart innovations include farmer heterogeneity in terms of benefits and costs of the innovations (Suri, 2011).

Climate-smart innovations are theorized to affect food system outcomes i.e., the end outcomes of farm households' livelihood strategies, such as consumption, food security (dietary diversity, coping strategies, food consumption expenditure), human capital development (child growth), income (farm revenue or profits), poverty, risk coping (informal insurance, involuntary change of diets), and natural resource sustainability. Ultimately, they contribute to agricultural and economic development (e.g. increasing income through higher yields) and human development (e.g. better nutrition). The impact of climate-smart agricultural innovations on food system outcomes is primarily channelled through their influence on food system activities. The food system activities include natural resources (land, soil, water) management, farm production, storage, marketing, and consumption (Beuchelt and Badstue, 2013). The next section discusses the potential channels through which the three climate-smart agricultural technologies and practices affect household welfare and risk coping.

\subsubsection{Impact pathways}

Agricultural households in developing countries are largely exposed to a plethora of climatic and non-climatic shocks that could undermine their ability to maintain their livelihood asset base or to reinvest in agriculture because of the possibility of further losses. They are vulnerable to shocks mainly due to weak adaptive capacity because of lack of resources, market failures, and poor institutional arrangements (Asfaw et al., 2018). These households may react to the various idiosyncratic and covariate shocks they face using ex-ante risk management strategies and ex-post risk coping strategies. They cope with a shortfall in food or income following a climate shock (ex-post) and adapt their livelihood strategies (ex-ante) in the context of climate variability. Farm households adopt climate-smart innovations primarily to respond to welfare issues 
and environmental risks they confront. The innovations could help them withstand the deleterious effects of climate variability and extremes (FAO, 2010). They would also help farm households turn bad outcomes from climate-related risks into opportunities through their self-protection (mitigation) and self-insurance (adaptation) benefits (Ehrlich and Becker, 1972; Hanley et al., 2007). The innovations considered in this dissertation are theorised to affect households' welfare and risk management through various channels.

The welfare impacts of CA are often channelled through its impact on intermediate outcomes. The immediate outcomes from CA use include improved farm productivity, reduced cost of production and reduced risk of crop failure. CA can contribute to poverty reduction by enhancing the natural resources base (land, soil, water) and by allowing farmers to produce more with the resources and inputs they already have that would ultimately increase farm productivity. It would improve adaptive capacity and household welfare by reducing the downside risk of crop failure and enhancing ecosystem services (Neufeldt et al., 2013). CA, in a broader sense, will contribute to agricultural growth, food security and welfare by increasing income, reducing production costs (relaxing production constraints) and ensuring the efficient use of resources (Godfray et al., 2010; Hobbs et al., 2008; FAO, 2014). However, the welfare benefits would be constrained by the high opportunity cost of some CA practices such as the use of crop residues for conservation.

In environments characterised by repeated exposure to shocks and market imperfections but absent formal risk management schemes, crop diversity could act as a natural insurance or self-insurance mechanism. Crop diversification is among the $e x-$ ante strategies that could also be considered a low-risk production strategy. It could primarily help farmers smooth income streams over time and decrease income risk (Arslan et al., 2017). It would improve household welfare and consumption smoothing by reducing the downside risk of crop failure and enhancing ecosystem services. In addition to its risk management benefits, crop diversity would support nutrition security in the context of market failures or poor market access. Households' decision to engage in risk coping could also be determined by their ex-ante livelihood strategies. Households with ex-ante risk management strategies would avoid or reduce use of adverse risk coping or consumption smoothing strategies that have higher opportunity costs. Some coping strategies may increase households' vulnerability to future shocks and put them in an intransigent poverty trap (Dercon, 2002; Dercon and Christiaensen, 2011). Thus, crop diversification would improve household welfare (e.g. consumption, income) and risk coping (consumption smoothing). However, not all households take crop diversification as a precautionary response to exogenous shocks.

Imperfections in savings and credits markets and postharvest losses create difficulties for farmers to convert harvest season output into lean season consumption, thereby leading to consumption shortfalls and hunger during lean seasons (Basu and 
Wong, 2015). Reducing postharvest losses encourage food storage, and thus increase the amount of food available to farm households for their own consumption or for sale to market (Park, 2006). This could be achieved using improved food storage technologies that would reduce storage loss, ultimately improving consumption smoothing and allowing farmers to benefit from temporal price enhancements (if food is stored for sale at a later period). Thus, postharvest storage technologies can be effective means of transferring and allocating food across the harvest and lean seasons. Food storage can be viewed as a subsidy of lean season consumption, making it relatively cheaper than consuming food during the harvest season (Basu and Wong, 2015). It can help to smooth consumption in the lean season by preventing harvest season consumption (substitution effect) and increasing food security in both the harvest and lean seasons. The use of improved storage technologies would enable farmers to keep food stocks as insurance against unanticipated food shortages. They could also prevent sales of harvest at a low price (time utility), which would increase household income (income effect) that can be invested in other development outcomes. Reducing postharvest losses can also reduce the likelihood that households become net food buyers, reduces total household expenditures on food and free up resources for other household benefits such as health and education (Lipinski et al., 2013). Crop storage also serves as a commitment device for savings by discouraging frequent withdrawals (Ashraf et al., 2006) or by enabling households to increase self-control or reduce social pressure to consume (Baland et al., 2011).

\subsection{STRUCTURE OF THE DISSERTATION}

This dissertation aims to increase our understanding of the microeconomic challenges facing rural households in SSA. We study the choices households make in the agricultural production process to cope with the issue of climate risks and food insecurity. The study follows a food systems approach to investigate how climate-smart agricultural innovation can bring about smart farming and improve welfare, productivity and risk management. There are three focal areas. Under the first focal area, focusing on the production side, we focus on CA as a strategy to offset the adverse impacts of climate change and soil nutrient constraints on food production. Under the second area, we find crop diversity that helps farm households to balance the goals of improving household welfare and risk management. The third focal area relates to food storage practices that reduce postharvest loss, climate-related food safety and price risk concerns. In what follows, we highlight the research gap addressed and the contribution of the study to the literature and the policy discourse.

Chapter 2 investigates the potential of CA in poverty reduction in Ethiopia. Given that most Ethiopians still live in rural areas and make their livelihoods in agriculture, this chapter presents a sobering portrait of the potential of CA practices in dealing with the exigencies of being poor. CA is among the agricultural production systems 
that have received attention for its potential to sustainably improve productivity along with its climate change adaptation and mitigation benefits. However, the existing literature on CA seems more focused on its adoption and yield and agronomic benefits. While considerable evidence exists about its agroecological and ecosystem benefits, there is a dearth of evidence on CA's welfare impacts. Due to lack of rigorous empirical evidence, there are contentions surrounding the viability and suitability of CA in the farming systems of SSA.

To contribute to this knowledge gap in the literature, we investigate the impact of CA on rural poverty in Ethiopia. A panel data endogenous switching regression in a polychotomous technology choice setting is used because it has both theoretical and empirical appeals to control for structural differences in observed and unobserved characteristics of the CA technology users and non-users. The chapter provides evidence that minimum tillage, cereal-legume intercropping and their combination are the CA practices that contribute to rural poverty reduction among farm households. These CA practices have significant effect on increasing farm productivity, reducing the cost of production and curbing the risk of crop failure. We also disaggregate the impacts of CA on poverty for households with different exposure to rainfall shocks and resource endowments. Furthermore, the chapter demonstrates how climate anomalies, soil nutrient constraints, and demographic factors predict CA use decisions. The detailed analysis of the impact and determinants of CA use provides evidence that could help to explain the uneven and unstable CA adoption puzzle in SSA.

In chapter 3, we empirically examine the household welfare and risk coping impacts of crop diversification using panel data from Uganda. Rural households confront a multitude of weather and related shocks that have significant repercussions on their well-being (Beegle et al., 2006; Dercon, 2004; Kassie et al., 2015; Kazianga and Udry, 2006). In the absence of adequate risk management mechanisms such as insurance, credit markets or formal social safety nets (Rosenzweig and Wolpin, 1993; Udry, 1990), rural households in developing countries often react to environmental and economic shocks through crop diversification (Arslan et al., 2017; Asfaw et al., 2018; Kassie et al., 2015). Recent agricultural development policies in SSA also focus on promoting crop diversification as a climate-smart agricultural practice to manage climatic risks, generate ecological benefits and build livelihood resilience (Arslan et al., 2017; Michler and Josephson, 2017). While there are many seminal works and a growing body of literature that have established the link between risk, diversification and investment (Carter et al., 2007; Dercon, 2002; Dercon and Christiaensen, 2011; Rosenzweig and Wolpin, 1993), the welfare and consumption smoothing effect of crop diversity has only recently began receiving attention.

Although the economic benefits of crop diversification seems to be clear from the literature, the emerging work on the topic fails to address some basic issues that motivate the current study. To contribute to the emerging literature that links crop diversity 
and household welfare, the chapter empirically investigates (a) the effect of crop diversity (ex-ante risk management strategy) on household welfare metrics (household consumption expenditure and dietary diversity) and (b) the link between crop diversity and consumption smoothing or risk coping in the form of solidarity networks of relatives and friends (informal insurance) or involuntary change in diets (ex-post coping strategies). Building on insights found in recent empirical works, we address the issue of endogeneity using climate variables and village level crop diversification as instruments for crop diversification. Panel data instrumental variables methods are used to control for reverse causality and unobserved heterogeneity in crop diversification. We also test if crop diversity generates non-linear and heterogeneous welfare effects using a quantile IV regression. The results are also contrasted with alternative econometric specifications and assumptions about exogeneity of crop diversification.

The primary finding from the chapter is that crop diversification is an attractive strategy to improve household nutrition and consumption. The finding suggests that for farm households that are primarily producers, growing a wider diversity of crops can improve dietary diversity and hence enures diet quality. Crop diversity both increases welfare on average and provides higher welfare benefits (as measured by consumption expenditure) for the poor segment of the sample than for households at the higher tail of the consumption distribution. This suggests that crop diversity could be a pro-poor strategy and could be a concerted pathway out of poverty. The results also show that crop diversification reduces households' reliance on informal insurance as a risk-coping or consumption smoothing strategy ex-post shocks. From policy perspectives, crop diversification could play a central role in the forward-looking climate change agenda that aims to create a climate- and nutrition-smart food system.

The economic role of crop storage in the face of exogenous shocks can be best explained by the Biblical account of Joseph's interpretation of the Pharaoh's dream (Genesis 41:1-36). Joseph foretold Pharaoh that, 7 years of abundant harvest would be followed by 7 years of famine, and he recommended the king accumulate grain during the good years as a hedge against the famine years. The topic attracts theoretical and empirical works that focus on investigating actors' motives for commodity (including crop) storage. Economic theory asserts that food storage plays a pivotal role in consumption smoothing (at farm level) and stabilising the economy (at the national level) in the face of exogenous disturbances. In a seminal work, Renkow (1990) showed that price seasonality (variation) alone partially explains food storage decisions under farm risk. The economic literature also elucidates that consumption smoothing (food security) and temporal price arbitrage are the two main economic motives for crop storage decisions in semi-subsistence economies (Park, 2006; Saha, 1994; Saha and Stroud, 1994). Park (2006) emphasizes that the food security or consumption smoothing motive is a stronger driver for crop storage. There is a well-established literature that links households' production decisions (e.g. technology adoption) and 
welfare outcomes to the neglect of the link between postharvest storage innovations and household welfare outcomes.

Chapter 4 contributes to the storage economics and agricultural innovation adoption and impact literature by exploring the effect of improved crop (food) storage technologies on household food and nutrition security, consumption expenditure and child growth in Ethiopia. The empirical strategy presented is endogenous switching regression framework that helps to account for selectivity bias due to observable and unobservable factors, and to capture the differential impacts of improved crop storage on users and non-users. The results are also contrasted with estimates obtained using quasi-experimental techniques. The primary finding of the chapter is that the use of improved storage innovations increases dietary diversity and reduces self-reported food insecurity at the household level. However, the effect on consumption expenditure is insignificant. This finding, to some extent, indicates that the food security objective of households is a major driving force for their crop storage decisions. The results also provide evidence that improved storage technologies help improve child growth by reducing the prevalence of stunted growth for children under 5 years of age. The findings suggest that improved storage innovations could have the capacity to reduce food insecurity, combat hunger and increase human development.

Overall, this dissertation provides evidence relevant to the development, marketing, and promotion of climate-smart agricultural technologies and farming practices in the agriculture and food security sectors. The chapters in the dissertation contribute to the emerging literature on CSA and the policy discourse centred on climate-smart practices and their potential benefit in improving household welfare. Such information is also useful for initiating a transition towards a more climate-resilient agricultural production and food systems. More importantly, given the effects of climatic factors on economic outcomes such as agricultural output, health, and economic growth, generating evidence regarding the benefits of climate-smart innovations is essential to the effective design of contemporary economic policies and institutions. 
Affognon, H., Mutungi, C., Sanginga, P., and Borgemeister, C. (2015). Unpacking Postharvest Losses in Sub-Saharan Africa: A Meta-Analysis. World Development, 66:49-68.

Arslan, A., Belotti, F., and Lipper, L. (2017). Smallholder productivity and weather shocks: Adoption and impact of widely promoted agricultural practices in Tanzania. Food Policy, 69:68-81.

Arslan, A., Mccarthy, N., Lipper, L., Asfaw, S., Cattaneo, A., and Kokwe, M. (2015). Climate Smart Agriculture? Assessing the Adaptation Implications in Zambia. Journal of Agricultural Economics, 66(3):753-780.

Asfaw, S., McCarthy, N., Lipper, L., Arslan, A., and Cattaneo, A. (2016). What determines farmers' adaptive capacity? Empirical evidence from Malawi. Food Security, $8(3): 643-664$.

Asfaw, S., Pallante, G., and Palma, A. (2018). Diversification strategies and adaptation deficit: Evidence from rural communities in Niger. World Development, 101:219-234.

Ashraf, N., Karlan, D., and Yin, W. (2006). Tying Odysseus to the Mast: Evidence from a Commitment Savings Product in the Philippines. Quarterly Journal of Economics, $121(2): 635-672$.

Bachewe, F. N., Berhane, G., Minten, B., and Taffesse, A. S. (2017). Agricultural Transformation in Africa? Assessing the Evidence in Ethiopia. World Development, 105:286-298.

Baland, J.-M., Guirkinger, C., and Mali, C. (2011). Pretending to Be Poor: Borrowing to Escape Forced Solidarity in Cameroon. Economic Development and Cultural Change, $60(1): 1-16$.

Barrett, C. B., Christiaensen, L., Sheahan, M., and Shimeles, A. (2017). On the structural transformation of rural Africa. Journal of African Economies, 26(suppl_1):i11-i35.

Basu, K. and Wong, M. (2015). Evaluating seasonal food storage and credit programs in east Indonesia. Journal of Development Economics, 115:200-216.

Beddington, J. R., Asaduzzaman, M., Clark, M. E., Bremauntz, A. F., Guillou, M. D., Jahn, M. M., Lin, E., Mamo, T., Negra, C., Nobre, C. A., et al. (2012). The role for scientists in tackling food insecurity and climate change. Agriculture $\mathcal{E}$ Food Security, I(1):10. 
Bibliography

Beegle, K., Dehejia, R. H., and Gatti, R. (2006). Child labor and agricultural shocks. Journal of Development Economics, 81(1):80-96.

Beuchelt, T. D. and Badstue, L. (2013). Gender, nutrition- and climate-smart food production: Opportunities and trade-offs. Food Security, 5(5):709-721.

Bradshaw, B., Dolan, H., and Smit, B. (2004). Farm-level adaptation to climatic variability and change: Crop diversification in the Canadian prairies. Climatic Change, 67(1):119-141.

Brown, M. and Funk, C. (2008). Climate: Food security under climate change. Science, 319(5863):580-581.

Carter, M. R., Little, P. D., Mogues, T., and Negatu, W. (2007). Poverty Traps and Natural Disasters in Ethiopia and Honduras. World Development, 35(5):835-856.

Castells-Quintana, D., del Pilar Lopez-Uribe, M., and McDermott, T. K. (2018). Adaptation to climate change: A review through a development economics lens. World Development, 104:183-196.

Christiaensen, L. and Demery, L. (2007). Down to Earth: Agriculture and Poverty Reduction in Africa.

Christiaensen, L., Demery, L., and Kuhl, J. (2011). The (evolving) role of agriculture in poverty reduction: An empirical perspective. Journal of Development Economics, 96(2):239-254.

Cline, W. R. (2008). Global warming and agriculture. Finance and Development, 45(1):23.

Davis, B., Di Giuseppe, S., and Zezza, A. (2017). Are African households (not) leaving agriculture? Patterns of households' income sources in rural Sub-Saharan Africa. Food Policy, 67:153-174.

de Janvry, A. and Sadoulet, E. (2011). Subsistence farming as a safety net for foodprice shocks. Development in Practice, 21(June):472-480.

Dercon, S. (1996). Risk, Crop Choice, and Savings: Evidence from Tanzania. Economic Development and Cultural Change, 44(3):485-513.

Dercon, S. (2002). Income risk, coping strategies, and safety nets. The World Bank Research Observer, 17(2):141-166.

Dercon, S. (2004). Growth and shocks: Evidence from rural Ethiopia. Journal of Development Economics, 74(2):309-329.

Dercon, S. and Christiaensen, L. (2011). Consumption risk, technology adoption and poverty traps: Evidence from Ethiopia. Journal of Development Economics, 96(2):159173. 
Di Falco, S. and Chavas, J. P. (2009). On crop biodiversity, risk exposure, and food security in the highlands of Ethiopia. American Journal of Agricultural Economics, 91(3):599-611.

Di Falco, S., Veronesi, M., and Yesuf, M. (2011). Does Adaptation to Climate Change Provide Food Security? A Micro-Perspective from Ethiopia. American Journal of Agricultural Economics, 93(3):829-846.

Dzanku, F. M., Jirström, M., and Marstorp, H. (2015). Yield Gap-Based Poverty Gaps in Rural Sub-Saharan Africa. World Development, 67:336-362.

Ehrlich, I. and Becker, G. S. (1972). Market insurance, self-insurance, and selfprotection. Journal of Political Economy, 8o(4):623-648.

FAO (2010). “Climate-Smart' Agriculture: Policies, Practices and Financing for Food Security, Adaptation and Mitigation. Food and Agriculture Organization of the United Nations, Rome. Technical report, Food and Agriculture Organization of the United Nations, Rome.

FAO (2011). Global food losses and food waste. Extent, Causes and Prevention. Technical report.

FAO (2012). Crop diversification for sustainable diets and nutrition: The role of FAO's Plant Production and Protection Division. Technical report, Food and Agriculture Organization of the United Nations (FAO), Rome.

FAO (2013). Climate-Smart Agriculture Sourcebook. Food and Agriculture Organization of the United Nations.

FAO (2014). The state of food and agriculture: Innovation in family farming. Technical report, Food and Agriculture Organization of the United Nations, Rome.

FAO (2016). The State of Food and Agriculture: Climate change, Agriculture and Food Security. Technical report, Food and Agriculture Organization of the United Nations, Rome, Italy.

FAO, IFAD, UNICEF, WFP, and WHO (2018). The state of food security and nutrition in the world 2018. building climate resilience for food security and nutrition. Technical report, Food and Agriculture Organization of the United Nations, Rome.

Feder, G., Just, R., and Zilberman, D. (1985). Adoption of Agricultural Innovations in Developing Countries: A Survey. Economic Development and Cultural Change, 33(2):255-298.

Foley, J. a., Ramankutty, N., Brauman, K. a., Cassidy, E. S., Gerber, J. S., Johnston, M., Mueller, N. D., Connell, C. O., Ray, D. K., West, P. C., Balzer, C., Bennett, E. M., Sheehan, J., Siebert, S., Carpenter, S. R., Hill, J., Monfreda, C., Polasky, S., Rockstro, 
J., Tilman, D., and Zaks, D. P. M. (2011). Solutions for a cultivated planet. Nature, 478(7369):337-342.

Frankema, E. (2014). Africa and the green revolution a global historical perspective. NJAS-Wageningen Journal of Life Sciences, 70:17-24.

Garnett, T., Appleby, M., Balmford, A., Bateman, I., Benton, T., Bloomer, P., Burlingame, B., Dawkins, M., Dolan, L., Fraser, D., et al. (2013). Sustainable intensification in agriculture: premises and policies. Science, 341(6141):33-34.

Gatzweiler, F. W. and Von Braun, J. (2016). Technological and institutional innovations for marginalized smallholders in agricultural development. Springer.

Godfray, H. C. J., Beddington, J. R., Crute, I. R., Haddad, L., Lawrence, D., Muir, J. F., Pretty, J., Robinson, S., Thomas, S. M., and Toulmin, C. (2010). Food security: the challenge of feeding 9 billion people. Science, 327(5967):812-8.

Godfray, H. C. J. and Garnett, T. (2014). Food security and sustainable intensification. Philosophical Transactions of the Royal Society of London. Series B, Biological sciences, 369(1639):20120273.

Grabowski, P. P., Kerr, J. M., Haggblade, S., and Kabwe, S. (2016). Determinants of adoption and disadoption of minimum tillage by cotton farmers in eastern Zambia. Agriculture, Ecosystems and Environment, 231:54-67.

Hanley, N., Shogren, J. F., and White, B. (2007). Environmental Economics in Theory and Practice. Number 333.7 H241. Palgrave Macmillan.

Hazell, P., Poulton, C., Wiggins, S., and Dorward, A. (2010). The Future of Small Farms: Trajectories and Policy Priorities. World Development, 38(10):1349-1361.

Hobbs, P., Sayre, K., and Gupta, R. (2008). The role of conservation agriculture in sustainable agriculture. Philosophical Transactions of the Royal Society B: Biological Sciences, 363(1491):543-555.

IPCC (2014). Climate Change 2014-Impacts, Adaptation and Vulnerability: Regional Aspects (Intergovernmental Panel on Climate Change, 2014). Cambridge University Press.

Jayne, T. S., Sitko, N. J., Mason, N. M., and Skole, D. (2018). Input subsidy programs and climate smart agriculture: Current realities and future potential. In Climate Smart Agriculture, pages 251-273. Springer.

Jirata, M., Grey, S., and Kilawe, E. (2016). Ethiopia Climate-Smart Agriculture Scoping Study. Technical report, Food and Agriculture Organization of the United Nations (FAO), Addis Ababa.

Juma, C., Tabo, R., Wilson, K., and Conway, G. (2013). Innovation for Sustainable Intensification in Africa. Montpellier Panel Briefing, Agriculture for Impact, London. 
Kassie, M., Teklewold, H., Marenya, P., Jaleta, M., and Erenstein, O. (2015). Production Risks and Food Security under Alternative Technology Choices in Malawi: Application of a Multinomial Endogenous Switching Regression. Journal of Agricultural Economics, 66(3):640-659.

Kazianga, H. and Udry, C. (2006). Consumption smoothing? Livestock, insurance and drought in rural Burkina Faso. Journal of Development Economics, 79(2):413-446.

Lipinski, B., Hanson, C., Lomax, J., Kitinoja, L., Waite, R., and Searchinger, T. (2013). Reducing Food Loss and Waste. Technical Report May, Washington, DC.

Lipper, L., McCarthy, N., Zilberman, D., Asfaw, S., and Branca, G. (2018). Climate smart agriculture: Building resilience to climate change. Natural Resource Management and Policy, 52.

Lobell, D. B., Burke, M. B., Tebaldi, C., Mastrandrea, M. D., Falcon, W. P., and Naylor, R. L. (2008). Prioritizing climate change adaptation needs for food security in 2030. Science, 319(5863):607-610.

Lybbert, T. J. and Sumner, D. A. (2012). Agricultural technologies for climate change in developing countries: Policy options for innovation and technology diffusion. Food Policy, 37(1):114-123.

Majiwa, E., Lee, B. L., and Wilson, C. (2018). Increasing agricultural productivity while reducing greenhouse gas emissions in sub-Saharan Africa: myth or reality? Agricultural Economics, 49(2):183-192.

Marenya, P. P. and Barrett, C. B. (2009). State-conditional fertilizer yield response on Western Kenyan Farms. American Journal of Agricultural Economics, 91(4):991-1006.

Masters, W. A., Rosenblum, N. Z., and Alemu, R. G. (2018). Agricultural transformation, nutrition transition and food policy in africa: Preston curves reveal new stylised facts. Journal of Development Studies, 54(5):788-802.

Michler, J. D. and Josephson, A. L. (2017). To Specialize or Diversify: Agricultural Diversity and Poverty Dynamics in Ethiopia. World Development, 89:214-226.

Neufeldt, H., Jahn, M., Campbell, B. M., Beddington, J. R., DeClerck, F., De Pinto, A., Gulledge, J., Hellin, J., Herrero, M., Jarvis, A., LeZaks, D., Meinke, H., Rosenstock, T., Scholes, M., Scholes, R., Vermeulen, S., Wollenberg, E., and Zougmoré, R. (2013). Beyond climate-smart agriculture: toward safe operating spaces for global food systems. Agriculture E Food Security, 2:12.

Noguera-Santaella, J. (2017). Is Sub-Saharan Africa catching up? Empirical Economics, 52(2):555-575. 
Nyasimi, M., Amwata, D., Hove, L., Kinyangi, J., and Wamukoya, G. (2014). Evidence of impact: Climate Smart Agriculture in Africa. Climate Change, Agriculture and Food Security (CCAFS) Working Paper No. 86. Copenhagen, Denmark, page 44.

OECD and Eurostat (2005). Oslo Manual: Guidelines for collecting and interpreting innovation Data, third edition. Organisation for Economic Cooporation and Development (OECD).

Park, A. (2006). Risk and household grain management in developing countries. Economic Journal, 116(514):1088-1115.

Pretty, J., Toulmin, C., and Williams, S. (2011). Sustainable intensification in African agriculture. International Journal of Agricultural Sustainability, 9(1):5-24.

Renkow, M. (1990). Household Inventories and Marketed Surplus in Semisubsistence Agriculture. American Journal of Agricultural Economics, 72(3):664-675.

Rockström, J., Steffen, W., Noone, K., Persson, Å., Chapin III, F. S., Lambin, E. F., Lenton, T. M., Scheffer, M., Folke, C., Schellnhuber, H. J., et al. (2009). A safe operating space for humanity. Nature, 461(7263):472.

Rosenzweig, M. R. and Binswanger, H. P. (1993). Wealth, Weather Risk and the Composition and Profitability of Agricultural Investments. Economic Journal, 103(416):5678 .

Rosenzweig, M. R. and Wolpin, K. I. (1993). Credit Market Constraints, Consumption Smoothing, and the Accumulation of Durable Production Assets in Low-Income Countries: Investments in Bullocks in India. Journal of Political Economy, 101(2):223244 .

Saha, A. (1994). A two-season agricultural household model of output and price uncertainty. Journal of Development Economics, 45(2):245-269.

Saha, A. and Stroud, J. (1994). A Household Model of On-Farm Storage under Price Risk. American Journal of Agricultural Economics, 76(3):522-534.

Saj, S., Torquebiau, E., Hainzelin, E., Pages, J., and Maraux, F. (2017). The way forward: an agroecological perspective for climate-smart agriculture. Agriculture, Ecosystems $\mathcal{E}$ Environment, 250:20-24.

Sanchez, P. A. (2002). Soil fertility and hunger in Africa. Science, 295(5562):2019-2020.

Schumpeter, J. (1939). Business cycles: A theoretical, historical and statistical analysis of the capitalist process, volume 1. McGraw-Hill, New York.

Stathers, T., Lamboll, R., and Mvumi, B. M. (2013). Postharvest agriculture in changing climates: Its importance to African smallholder farmers. Food Security, 5(3):361-392. 
Suri, T. (2011). Selection and comparative advantage in technology adoption. Econometrica, 79(1):159-209.

Tefera, T., Kanampiu, F., De Groote, H., Hellin, J., Mugo, S., Kimenju, S., Beyene, Y., Boddupalli, P. M., Shiferaw, B., and Banziger, M. (2011). The metal silo: An effective grain storage technology for reducing post-harvest insect and pathogen losses in maize while improving smallholder farmers' food security in developing countries. Crop Protection, 30(3):240-245.

Tittonell, P. and Giller, K. E. (2013). When yield gaps are poverty traps: The paradigm of ecological intensification in African smallholder agriculture. Field Crops Research, 143:76-90.

Udry, C. (1990). Credit Markets in Northern Nigeria: Credit as Insurance in a Rural Economy. World Bank Economic Review, 4(3):251-269.

United Nations (2009). The Millennium Development Goals Report 2009. Technical report, New York.

United Nations (2011). World economic and social survey 2011: The great green technological transformation. Technical report, United Nations UN DESA, New York.

van Ittersum, M. K., Van Bussel, L. G., Wolf, J., Grassini, P., Van Wart, J., Guilpart, N., Claessens, L., de Groot, H., Wiebe, K., Mason-D'Croz, D., Boogaard, H., Cassman, H., van Oort Marloes P., P. A. J., and Kenneth G., v. L. (2016). Can sub-Saharan Africa feed itself? Proceedings of the National Academy of Sciences, 113(52):14964-14969.

Wheeler, T. and Von Braun, J. (2013). Climate change impacts on global food security. Science, 341(6145):508-513.

Winterbottom, R., Reij, C., Garrity, D., Glover, J., Hellums, D., McGahuey, M., and Scherr, S. (2013). Improving land and water management. World Resources Institute, (October):1-44.

Wood, S. A., Jina, A. S., Jain, M., Kristjanson, P., and DeFries, R. S. (2014). Smallholder farmer cropping decisions related to climate variability across multiple regions. Global Environmental Change, 25:163-172.

World Bank (2010). Innovation Policy: a guide for developing countries. World Bank Group. 



\section{2}

CONSERVATION AGRICULTURE AND POVERTY IN RURAL ETHIOPIA*

\subsection{INTRODUCTION}

Rural poverty remains prevalent and an increasing concern in Sub-Saharan Africa (SSA) (Barrett et al., 2017; Hansen et al., 2018). Smallholder farmers make a significant proportion of the population that is caught in a web of poverty, mainly due to low agricultural productivity. The agriculture sector in SSA continues to underperform due to farmers' reliance on poor and unsustainable farming practices that lead to land degradation and poor soil fertility (Marenya and Barrett, 2009; Tittonell and Giller, 2013; Grabowski et al., 2016). Climate change appears to be a major source of risk for agricultural production in SSA (Cline, 2008; IPCC, 2014; Jayne et al., 2018). Farm households pay the heaviest toll since their livelihood is dependent on rain-fed agriculture and they operate in environments characterized by weak institutions (Dercon and Christiaensen, 2011; Kassie et al., 2015; Hansen et al., 2018). Weather-induced risks pose a threat to agricultural productivity through exacerbating production risks, increasing risk exposure (Di Falco et al., 2011), and altering rural households' incentives to innovate and invest in remunerative activities (Dercon and Christiaensen, 2011; Emerick et al., 2016). Low and erratic rainfall also leads to soil moisture stress, another important constraint to agricultural production (Thierfelder et al., 2017). With farmers facing climate variability and extremes, soils with low moisture content could lead to low crop yields and crop failure that would exacerbate rural poverty (Dzanku et al., 2015; Asfaw et al., 2016b).

Due to the increasing challenges of climate change, shrinking agricultural frontiers and declining soil fertility (Marenya et al., 2015; Grabowski et al., 2016), feeding a surging population (that is expected to double to 2 billion by 2050) and alleviating rural poverty is a challenge in the current agricultural development policy (Di Falco et al., 2011; van Ittersum et al., 2016). The solution to address these intertwined challenges requires a new paradigm for transforming African agriculture. Since the farming systems of SSA are capital-deficient, prone to weather extremes and have poor quality soils (Marenya and Barrett, 2009; Kassie et al., 2015), the development and promotion

* The chapter is co-authored with Nyasha Tirivayi (UNU-MERIT) and Garrick Blalock (Cornel University). The work is part of the Structural Transformation of African Agriculture and Rural Spaces (STAARS) fellowship. 
of technologies and practices that could help to improve soil quality and increase crop yields have no parallels in the process of African agricultural transformation and to address the multiple challenges of climate change and low agricultural production (Wheeler and Von Braun, 2013; Dzanku et al., 2015). Sustainable intensification is uniquely positioned as a way forward for African agricultural transformation (Pretty et al., 2011; Garnett et al., 2013; Godfray and Garnett, 2014; Juma et al., 2013). One of the options for promoting sustainable agricultural production is the utilization of "climate-smart" agricultural technologies and practices that could support agricultural production and enhance adaptive capacity by cushioning against the effects of climate change (Bradshaw et al., 2004; Di Falco et al., 2011; Lipper et al., 2014; Asfaw et al., 2016b). As such, climate-smart agricultural practices are receiving greater attention in agricultural development policymaking to harmonize economic and environmental concerns (Kpadonou et al., 2017; Jayne et al., 2018).

Conservation agriculture (hereafter CA) is an example of a group of climate-smart agricultural practices that promote sustainable production and can improve households' resilience to weather shocks (FAO, 2013; Giller et al., 2011; Pittelkow et al., 2015). CA is a cropping system founded on three practices: minimum or reduced tillage, cereal-legume rotation or intercropping, and the retention of crop residues or mulch (Hobbs, 2007; Ito et al., 2007; Kassam et al., 2009). Being central to the sustainable intensification concept, CA has increasingly been promoted as a viable alternative to conventional farming. It is believed that CA helps farm households address their poor production outcomes, manage climate risks, and prevent environmental degradation (Hobbs et al., 2008). ${ }^{1}$ CA can play both a climate change adaptation (self-insurance) and mitigation (self-protection) role against environmental (rainfall and soil fertility related) shocks (Ehrlich and Becker, 1972; Hanley et al., 2007). Thus, CA is among the production technologies and farm practices that concentrate on addressing the links between climate change, soil fertility, farm profits, and rural poverty.

The literature on the economics of CA seems to be dominated by a bulk of studies that focus on the drivers of CA adoption (Knowler and Bradshaw, 2007; Andersson and D'Souza, 2014; Arslan et al., 2014; Grabowski et al., 2016). Existing studies show that the factors influencing CA adoption in SSA include high weed pressure due to reduced tillage, labor constraints during weeding time (Giller et al., 2009; Pannell et al., 2014; Lalani et al., 2016), lack of knowledge about CA and its benefits (Lalani et al., 2016), the time lag between adoption and realization of benefits (Thierfelder et al., 2017), and competition for resources (Baudron et al., 2014; Tessema et al., 2015). ${ }^{2}$ Studies related to this body of the literature have also tried to delve into the debate

1 Although CA provides food security, climate change adaptation and mitigation benefits (FAO, 2010, 2013; Lipper et al., 2014), smallholder farmers will benefit more from enhanced food security/agricultural productivity, increased income and greater resilience (Neufeldt et al., 2011). See Steward et al. (2018) for a recent meta-analysis on the adaptive capacity benefits of CA in the tropics and sub-tropics.

2 There is lag of 2-5 cropping seasons until yield benefits from CA become significant and contribute to increased profitability (Thierfelder et al., 2017). However, some CA practices have short term and 
surrounding the suitability, effectiveness, and potential benefits of CA in SSA (Giller et al., 2009; Rodriguez et al., 2017). One important concern is the high opportunity cost of crop residues (biomass) which are valuable resources with alternative uses for farming households in SSA. Crop residues can be used as livestock feed, an energy source, building materials, source of cash, or simply burnt in the field (Jaleta et al., 2015; Rodriguez et al., 2017). Thus, the benefits of recycling crop residues back into the cropping system as mulch may not be worth the trade-off of giving up its other benefits.

Another strand of the literature on the economic benefits of CA is devoted to analyzing its productivity impacts (Teklewold et al., 2013; Arslan et al., 2015; Ngoma et al., 2016; Jaleta et al., 2016; Teklewold and Mekonnen, 2017; Ngoma, 2018), production risk-reducing effects (Kassie et al., 2015), and adaptive capacity benefits (Kassie et al., 2015; Arslan et al., 2015, 2017). However, the literature on the economics of CA that focuses on its welfare impacts is rather sparse and inconclusive (Hansen et al., 2018; Tambo and Mockshell, 2018). There is limited evidence that identifies the impact of CA on household poverty (Hansen et al., 2018). Among the few studies is Abdulai (2016) which finds that CA reduces the incidence of household poverty in Zambia. Farris et al. (2017) also show that an increase in farm profit due to CA reduces poverty incidence in Uganda. Very recently, Tambo and Mockshell (2018) analyze the impact of CA adoption on household income using data from nine SSA countries and find that CA has no impact on income in Ethiopia. These studies are based on cross-sectional data which may limit the analysis from fully controlling for unobserved endogeneity (Pannell et al., 2014; Michler et al., 2018). Using panel data econometrics with economic surplus analysis, Kassie et al. (2017) find that legume-diversification, an important anchor of CA, contributes to poverty reduction in Ethiopia when used with fertilizer and improved maize seeds. While informative, results from analysis of only a single CA practice do not provide adequate evidence for exploring the potential incentives for the wider scale adoption of a combination of CA practices that would generate higher returns. Khonje et al. (2018) investigate the impact of improved seeds and CA using panel data from Zambia and find that joint adoption of the technologies had greater impact on crop yields, income and poverty. However, the authors adopt a holistic approach to define CA adoption. In fact, Giller et al. (2009) argue that lack of evidence on the economic impacts of CA disaggregated by its different components makes the refinement, targeting, and extension of CA difficult.

This chapter aims to make contributions to the literature by establishing an empirical link between CA (single practices and combinations) and household poverty while addressing potential selection bias and unobserved endogeneity. We answer an important question in the literature regarding whether CA help lift rural households out of poverty. To elucidate the possible impact pathways, we assess the impact of CA

immediate benefits such as reduced labor demands and cost of farm inputs that make them attractive for farmers. 
on farm productivity (crop income), production cost and risk of crop failure. Moreover, we investigate the distributional effect of CA adoption by looking at impacts across rainfall endowments and wealth groups. The study is based on a panel household survey data from Ethiopia provided from the Living Standards Measurement Study-Integrated Surveys on Agriculture (LSMS-ISA) of the World Bank merged with a historical rainfall data extracted from the Climate Hazards Group InfraRed Precipitation with Station data (CHIRPS). The rich nature of the data helps us examine the role of a wide vector of socioeconomic, farm characteristics and biophysical (rainfall and soil) conditions in determining variation in CA use and household poverty. The empirical strategy used is multinomial endogenous switching regression (MESR) model combined with panel data estimator that allows us to account for farm heterogeneity in the decision to use CA and to account for potential endogeneity bias due to timeinvariant and time-varying unobservable factors. The study provides new insights that help explain the unstable and low uptake of CA (particularly a combination of CA practices) and feed into the current polarised policy debate regarding the attractiveness of CA in SSA. Overall, the chapter provides insights that can help in targeting CA initiatives for climate change adaptation, agricultural transformation and poverty reduction.

The rest of the chapter is structured as follows. Section 2.2 provides an overview of the study country (Ethiopia) with a focus on the prevailing development challenges and the promotion of CA in the country. Section 2.3 presents a theoretical model that guides the choice of the empirical strategy described in section 2.4. Section 2.5 discusses the data (sources) and provides descriptive statistics results. The main findings of the study are presented and discussed in section 2.6. The last section concludes with policy implications.

\subsection{COUNTRY CONTEXT AND CA PROMOTION}

Agriculture is the core sector of the Ethiopian economy and the main source of livelihood for a significant proportion of the population (Di Falco and Veronesi, 2013; Abro et al., 2014; Bachewe et al., 2017). ${ }^{3}$ The sector is primarily rain-fed that makes it prone to various weather-related shocks and stresses such as spatial and temporal temperature and rainfall variability and drought (Teklewold et al., 2013; Di Falco and Veronesi, 2013). As a result, the sector is characterized by low and variable agricultural productivity. Harvest failure due to weather events is the most important cause of risk-related hardship in the country with adverse effects on household welfare (Dercon, 2004; Dercon et al., 2005). Other key drivers of low agricultural production and productivity include farmers' reliance on unsustainable farming practices that lead to soil degradation. Low agricultural productivity, coupled with consistent population growth and

3 Detail information can be found here: https://ccafs.cgiar.org/publications/climate-smart-agricultureethiopia.XCzUKFxKjcs 
other structural and institutional impediments, leads to food insecurity, persistent poverty and impaired social and economic development in the country. Poverty is pervasive and widespread particularly in rural Ethiopia (Abro et al., 2014; Bachewe et al., 2017). More than $40 \%$ of the rural population lives below the national poverty line (Michler and Josephson, 2017; Verkaart et al., 2017).

Tackling climate change and land degradation are major priorities for Ethiopia to reduce the depth and extent of poverty. In response to the aforementioned interrelated development challenges, a multitude of agricultural development activities have been undertaken in Ethiopia. CA is one of the numerous agricultural development activities employed in Ethiopia to improve crop productivity while addressing issues related to climate change, poor soil fertility, and preserving the underlying natural resource base (Marenya et al., 2015; Jirata et al., 2016). ${ }^{4}$ The promotion of CA in Ethiopia began in 1998 through the joint promotion and demonstration of the technology on farmers' plots by Sasakawa Global (SG200o), Makobu and regional agricultural development bureaus (Jirata et al., 2016; Tessema et al., 2016). Although the results from the initial periods of CA implementation were not appealing, encouraging results (in terms of improved crop yields) were obtained from further trials (Sime et al., 2015; Jirata et al., 2016).

Since the initial periods of trials and introduction, different organizations have been promoting CA in different regions of Ethiopia. FAO collaborates with federal and regional agricultural offices and provided technical and financial support for CA promotion through demonstration plots, introducing different CA equipments (including jab planters and oxen-drawn seed and fertilizer planters) and training of extension agents in Amhara, Oromia and Tigray regions starting from 2010. The International Maize and Wheat Improvement Center (CIMMYT), in a joint effort with national and regional research organizations (mainly the Ethiopian Institute of Agricultural Research), has been conducting CA trials and demonstrations in various parts of the country. In 2012 and 2013, Agricultural Transformation Agency (ATA) of Ethiopia supported 6,000 farmers in 7 districts who practiced CA, trained 327 experts and 750 development agents (Jirata et al., 2016). Ethiopia's Climate Resilient Green Economy strategy also advocates CA (mainly zero or reduced tillage) as one of the climate change adaptation options (Teklewold and Mekonnen, 2017). Other stakeholders involved in the promotion of CA in Ethiopia include Ministry of Agriculture, the National Agricultural Research System (NARS) and numerous non-governmental organizations (NGOs) (Jirata et al., 2016).

4 See Jirata et al. (2016) for the various projects and programs that have been supporting sustainable land management and climate change adaptation activities in Ethiopia. 


\subsection{THEORETICAL FRAMEWORK}

This study estimates the impact of CA use on poverty. The decision to use CA could be analyzed using a random utility framework in which farmers or households choose one or more CA practices that increase utility (Tambo and Mockshell, 2018). CA choice decision can be considered as a constrained optimization problem at the beginning of the agricultural season based on available information, expectations regarding the coming year's growing conditions, and the relative costs and benefits of CA (Suri, 2011; Pannell et al., 2014).

The household makes polychotomous decision whether to adopt CA: minimum tillage $(T)$, crop residue retention or mulch $(R)$ and cereal-legume intercropping $(C)$, and their combinations. The choice of CA practices in isolation or in combination leads to eight mutually exclusive CA choice sets including an empty set in which none of the CA practices is adopted (see Table 2.1). For each CA practice or combination of practices, there is a corresponding outcome level. We are interested in the outcome differences between the CA users and the counterfactual - the outcomes had the household not used CA. This difference is called the "treatment effect" (Rubin, 1978) which we can call the "CA use effect".

The measurement of CA use and its impact on poverty is complicated due to the non-separability of households' production decisions and consumption preferences (Singh et al., 1986; de Janvry et al., 1991). Rural households in rural Ethiopia operate in an environment characterized by weak institutions and incomplete markets (Marenya et al., 2015; Teklewold et al., 2013; Verkaart et al., 2017). The absence of formal risk management and pooling mechanisms and weak markets make production decisions (e.g. CA adoption) and consumption preferences non-separable. Imperfect rural labor markets, information asymmetry and high transaction costs constrain the capacity of resource poor households to adopt labor and knowledge intensive technologies and farming practices such as CA (Kpadonou et al., 2017). Credit market imperfection also limits households' investment in capital-intensive innovations (Mutenje et al., 2016). The seasonality and underdevelopment of output markets (e.g., grain markets) often discourage technology investments and could limit the implementation of CA practices such as cereal-legume diversification and crop residue retention in mixed crop-livestock production farming systems (Tessema et al., 2015).

CA use decision could also be determined based on differences in expected net farm returns (farm profits) between $\mathrm{CA}$ and non CA or Conventional farming (CF). The profit functions for CA and non-CA (CF) farmers at time $t$ can be represented as the difference between revenue and costs as follows

$$
\pi_{i t}^{C A}=\sum p_{i t} Y_{i t}^{C A}-\sum \omega_{i t, m} X_{i t, m}^{C A}
$$




$$
\pi_{i t}^{C F}=\sum p_{i t} Y_{i t}^{C F}-\sum \omega_{i t, m} X_{i t, m}^{C F}
$$

where $Y_{i t}^{C A}$ and $Y_{i t}^{C F}$ are the vector of crop yields for the $i^{\text {th }} \mathrm{CA}$ and non CA (CF) farmers, respectively. $p_{i t}$ is a vector of crop prices which is assumed to be same for $\mathrm{CA}$ and non-CA farmers since there could be no distinction in the output market for CA and CF crops; $X_{i t}$ and $w_{i t}$ are vectors of inputs and input prices, respectively. Let the expected profit (or net income) from CA and non-CA be denoted by $\pi_{i t}^{* C A}$ and $\pi_{i t}^{* C F}$, respectively. The farmer decides to choose CA over CF if the optimized farm profit from CA exceeds the optimized farm profit from without CA, i.e., when $\pi_{i t}^{* C A}>\pi_{i t}^{* C F}$.

To understand the impact of CA on poverty, we must consider the various pathways through which CA would affect poverty. The poverty reducing effects of CA could primarily be channelled through its farm level impacts. CA would affect household poverty primarily through its effect on aggregate crop productivity (crop yields) and farm returns (crop income). Assuming crop and input prices to be same for CA and non CA farmers (from the profit functions), CA use decisions based on farm profits will primarily depend on yield and input use differences across CA and CF. Differences in yield and input use could lead to differences in farm income (profit) and cost of production that would ultimately affect welfare. Crop yield improvements will be obtained from the agronomic benefits of CA such as improved soil structure, increased organic matter, and reduced moisture stress (Tambo and Mockshell, 2018). The resulting increased crop yields may subsequently increase crop income and hence household consumption expenditure (Abdulai, 2016). Over several seasons, the incremental increase in consumption or income could help households grow out of poverty.

CA would affect household poverty through its potential role in reducing production costs (Tambo and Mockshell, 2018) and mitigating production risks (Teklewold et al., 2013; Kassie et al., 2015) that would enhance farm income. In addition, CA practices could save time and labour (especially in peak seasons) that can be reallocated to alternative income-generating activities. On the other hand, CA may increase household labour requirements for weeding if pesticides are not used, and thus reduce household income and consumption expenditure (Giller et al., 2009; Arslan et al., 2014). The other key channel through which CA would affect household poverty is through its risk buffering effect (Arslan et al., 2017; Michler et al., 2018). Using CA means a better quality of soil and higher resistance to climate (environmental) risks (Tambo and Mockshell, 2018). As a result, households that practice CA are less likely to face risk of crop failure.

Estimating the causal effect of CA on poverty is not easy. Unobserved farmerspecific comparative advantage (the gain from CA choice) might influence the decision to use CA (Suri, 2011). Comparative advantage also plays a key role in esti- 
mating the impact of CA on household poverty. CA choice could also be affected by time-invariant unobserved factors and time-varying (transitory) shocks that may also affect household poverty. Therefore, estimating the impact of CA on poverty without controlling for unobserved heterogeneity will lead to biased estimates. The next section discusses the empirical strategy utilized to measure impact of CA on household poverty while addressing for farmer heterogeneity.

\subsection{EMPIRICAL STRATEGY}

Estimating the effects of CA on household poverty and farm level outcomes is inherently subject to various endogeneity problems. Since CA use behaviour is not random, farmers' CA technology choice decision is likely to be determined by unobserved characteristics (such as farm management skills and ability, individual motivation, openness to innovation, preferences, etc) that would also be correlated with poverty and farm level outcomes (Mundlak, 2001; Suri, 2011). When households are not randomly assigned to CA users and non-users, they will self-select into CA use based on their capacity and expected returns which are heterogeneous (Wu and Babcock, 1998; Marenya and Barrett, 2009; Suri, 2011; Pannell et al., 2014). The choice to use CA may also be driven by unobserved farm characteristics such as soil fertility or soil quality. Farmers who actively choose no-till or reduced tillage for soil conservation or productivity-enhancing reasons might also be more likely to be different (or have different farms) than farmers who practice de facto no till systems because they do not have access to technology to facilitate tilling. Moreover, there may be heterogeneity in returns to CA (e.g., in terms of yield, cost or risk reduction) such that farmers with high returns to CA are the ones that practice CA (Suri, 2011). Regression of the outcomes on CA without correcting for the potential self-selection and unobserved heterogeneity may lead to erroneous estimates for the impact of CA adoption.

With panel data, the impact of CA can be recovered by addressing some of the endogeneity concerns raised above. For instance, fixed effects (FE) can help to control for unobserved endogeneity through eliminating the effect of time-invariant characteristics. However, the use of FE is inadequate to estimate the effects of CA for two reasons (Kassie et al., 2017). First, FE models assume that both observed and unobservable factors have homogeneous effect on household poverty for both CA users and nonusers. This is a stringent assumption since the economic outcomes of CA can be heterogeneous due to both observed and unobserved factors (Suri, 2011; Pannell et al., 2014; Kassie et al., 2017). Second, standard regressions such as FE assume that unobservable time-invariant variables are the only omitted variables that affect CA use and the outcomes. This assumption is less likely to hold because households might move in and out of CA use during the course of the panel due to changes in 
unobservable factors that could also affect the outcomes (Suri, 2011). Thus, standard regressions cannot help us take full account of farmer heterogeneity (Suri, 2011). ${ }^{5}$

To circumvent selection bias due to time-invariant and time-varying unobservables, we employ panel endogenous switching regression (ESR) model (Malikov and Kumbhakar, 2014). Since households face a CA use decision of a polychotomous nature, we utilize a multinomial ESR (MESR) model. Since separate outcome regressions are estimated for CA and non-CA households, the MESR allows interaction between the CA technology set choice and the control variables to capture the effect of CA technology choice on the shift of the intercept and slope of the welfare equation (Di Falco and Veronesi, 2013; Kassie et al., 2017). The other advantage of the MESR method is that it enables the construction of a counterfactual based on returns to characteristics of CA users and non-users (Kassie et al., 2017). The framework also helps us explore in depth the CA use decision and impact of the CA practices individually and in combination. Likewise, it enables us capture potential interrelationship among the specific CA practices and to identify the CA package that yields the highest payoff (Wu and Babcock, 1998).

Following Malikov and Kumbhakar (2014), we begin with the following generalized panel data switching regression model

$$
y_{i t, j}= \begin{cases}x_{i t, j} \beta_{j}+v_{i j}+v_{i t, j} & \text { if } C_{i t}=j \\ - & \text { otherwise }\end{cases}
$$

with

$$
C_{i t, j}^{*}=z_{i t, j} \alpha_{j}+u_{i}+\eta_{i t, j}
$$

where $i=1, \ldots, N$ indexes the household, $t=1, \ldots, T$ indexes time and $j=1, \ldots, J$ denotes the regimes. $y_{i t}$ is the outcome of interest (poverty or farm level outcomes) and $C_{i t}$ denotes CA choice (the practices in isolation or in combination). $x_{i t, j}$ and $z_{i t, j}$ are vectors of covariates such as household and farm characteristics and biophysical factors that may overlap. $v_{i j}$ and $u_{i}$ are household-specific unobserved effects that are allowed to be correlated with the covariates. $v_{i t, j}$ and $\eta_{i t, j}$ are disturbance terms that are assumed to be orthogonal to $x_{i t, j}$ and $z_{i t, j}$. The outcome variable $y_{i t, j}$ will be observed conditional on the selected CA regime $j . C_{i t, j}^{*}$ is a latent variable that govern the regime selection or switching (CA choice) with observable categorical responses. $\beta_{j}$ and $\alpha_{j}$ are parameters to be estimated. Least squares estimation of the outcome

5 Standard regressions such as Ordinary Least Squares (OLS) or Fixed Effects and Instrumental variables (IV) methods cannot help us account for farmer heterogeneity. If OLS or FE is used to estimate the impact by introducing dummy for CA, the coefficient suggests the impact to come from those who switch CA during the course of the panel (Suri, 2011). 
equation may not give consistent estimate of $\beta_{j}$ since possible correlation between $v_{i t, j}$ and $\eta_{i t, j}$ may also introduce some correlation between the explanatory variables and the disturbance terms in the outcome equation (Bourguignon et al., 2007). To address this and other econometric concerns, the above model (equation 2.3) is estimated using a multinomial endogenous switching regression (MESR) model in a two-stage framework (Bourguignon et al., 2007; Malikov and Kumbhakar, 2014).

The first stage involves modelling the drivers of CA choice. Households' CA choice (regime switching) is determined by a random utility framework in which at each time period $t$, a farmer $i$ chooses a CA technology set that maximizes expected utility. Let the utility from choosing a CA technology set $j$ be represented by a latent variable $C_{i t, j}^{*}$. A household chooses a CA technology set $j$ if its utility or expected return outweighs the utility that could be obtained from another CA technology set $k$ i.e., if $\varepsilon_{i t, j}=$ $\max _{k \neq j}\left(C_{i t, k}^{*}-C_{i t, j}^{*}\right)<0$.

We specify the latent model that describes farmer's CA adoption behaviour following Di Falco and Veronesi (2013) and from equation 2.4

$$
C_{i t, j}^{*}=Z_{i t, j} \alpha_{j}+u_{i}+\eta_{i t, j}
$$

with

$$
C_{i t}=\left\{\begin{array}{l}
0 \text { iff } C_{i t, 0}^{*}>\max _{k \neq 0}\left(C_{i t, k}^{*}\right) \\
\vdots \\
J \text { iff } C_{i t, J}^{*}>\max _{k \neq J}\left(C_{i t, k}^{*}\right)
\end{array}\right.
$$

In equation $2.5, Z_{i t, j}$ is a vector of variables that would affect the probability of choosing CA technology set $j$. Likewise, $u_{i}$ and $\eta_{i t, j}$ represent farmer heterogeneity and the time-varying unobserved factors or idiosyncratic errors, respectively. The $Z_{i t}$ and the idiosyncratic unobserved stochastic component are assumed to be uncorrelated (i.e. $\left.E\left(\eta_{i t, j} \mid Z_{i t, j}\right)=0\right)$. Under the assumption that $\eta_{i t, j}$ is independent and identically Gumbel distributed across all CA sets (the independence of irrelevant alternatives or IIA hypothesis) (Bourguignon et al., 2007; McFadden, 1973), equation 2.5 leads to multinomial logit model of the following form

$$
p_{i t, j}=\operatorname{Pr}\left(C_{i t}=j \mid Z_{i t}, u_{i}\right)=\frac{\exp \left(a_{j}+Z_{i t} \alpha_{j}+u_{i}\right)}{\sum_{k=1}^{J} \exp \left(a_{k}+Z_{i t} \alpha_{k}+u_{i}\right)}, j=1, \ldots, J
$$

where $p_{i j, t}$ is the probability that household $i$ will choose the CA set $j$ at time $t . Z_{i t}$ is a matrix of observable household characteristics (e.g., gender, age and education of the household head and household size) that are major factors determining labor availability, human capital, and risk preference, and hence CA use (Arslan et al., 2017). 
Wealth (farm size, asset wealth, livestock holding, credit access) are also included to control for factors such as risk and time preferences that determine the ability of farm households to introduce CA in their farming systems (Tanaka et al., 2010; Pannell et al., 2014; Tessema et al., 2015). We control for access to extension service, proximity to markets, road, soil nutrient availability and climate related variables. Time period and region dummies are introduced to capture temporal and spatial differences in agro-ecology, price, and institutions (Suri, 2011; Kassie et al., 2017). $a_{j}$ represents the specific constant term of CA technology set $j$. The parameter of interest is $\gamma_{j}$ which measures the effect of the determinants of CA adoption.

Equation 2.7 is estimated using pooled multinomial logit model with correction for unobserved heterogeneity using the Mundlak (1978) device (Wooldridge, 2002). The Mundlak approach helps us model the time-invariant individual unobserved effect $\left(u_{i}\right)$ as a linear projection of the averages of all time-varying observed variables as: $u_{i}=\pi \bar{Z}_{i}+e_{i}$. In addition to controlling for potential unobservable household and farm-specific effects, the Mundlak approach helps to avoid the problem of incidental parameters that might arise from using fixed effects in the multinomial logit model. The approach enables us to generate consistent estimates since the approach accommodates dependence between unobserved effects and the explanatory variables in the model. From the first-stage estimates, we derive the Inverse Mills Ratio (IMR) terms that serve as selectivity correction terms in the second stage. ${ }^{6}$

In the second stage, we estimate Ricardian-type outcome equation models (Mendelsohn et al., 1994) conditional on the selected CA technology set with selectivity correction, along with correction for potential unobserved heterogeneity using the Mundlak device. The second stage involves estimating the impacts of the selected CA choice set on poverty and the farm level outcomes. Each CA regime the household faces when making the CA technology choice leads to separate outcome equations. The treatment effects of interest, in this case, consist of various binary comparisons of the actual outcomes for CA users (any practice or combination) and the counterfactual scenario. Because, for each sample household, the dependent variable is observed for the selected CA technology set or regime only, a simple comparison of the outcomes for CA users (the selected regime) and nonusers (reference category) will yield inconsistent estimates. To get consistent estimates of the parameters of interest, we estimate the outcome equations following the approach by Bourguignon et al. (2007) that takes into account the correlation between the error terms of the multinomial logit model and the outcome equations.

$6 \lambda_{i t, j}=\frac{\phi\left[J_{\varepsilon_{j i t}}(. \mid \Gamma)\right]}{\Phi\left[J_{\varepsilon_{j i t}}(. \mid \Gamma)\right]}$ where $\phi($.$) is the standard normal probability density function (pdf) and \Phi($.$) is the$ standard normal cumulative distribution function (cdf). $J_{\varepsilon_{i t, j}}(. \mid \Gamma)=\Phi^{-1}\left(\Lambda_{\varepsilon_{i t, j}}(. \mid \Gamma)\right)$ where $\Lambda_{\varepsilon_{i t, j}}($.$) is the$ cdf of $\varepsilon_{i t, j}$ and $\Gamma=\left\{Z \alpha_{j} ; \bar{Z} \pi_{j} ; j=1, \ldots, J\right\}$. The selection correction terms are computed for each regime separately. The distributional and linearity assumptions and alternative approaches are discussed by Malikov and Kumbhakar (2014) and Bourguignon et al. (2007). 
The outcome equations for each possible regime $j$ with selection bias correction is specified as

$$
\begin{aligned}
& \text { Regime o : } Y_{i t, 0}=X_{i t, 0} \beta_{0}+\hat{\lambda}_{i t, 0} \sigma_{0}+\left(\hat{\lambda}_{i t, 0} T\right) \psi_{0}+v_{i 0}+\epsilon_{i t, 0,} \quad \text { if } j=0 \\
& \text { Regime J : } Y_{i t, J}=X_{i t, J} \beta_{J}+\hat{\lambda}_{i t, J} \sigma_{J}+\left(\hat{\lambda}_{i t, J} T\right) \psi_{J}+v_{i J}+\epsilon_{i t, J}, \quad \text { if } j=1, \ldots, J
\end{aligned}
$$

where $j=0$ denotes the null category where neither of the CA practices nor their combinations is used by the farmer, and $j=1,2, \ldots J$ indicates use of any CA practice or a combination of practices. $Y_{i t, j}$ represents the outcomes related with the selected regime $j(j=0, \ldots, J)$. $X_{i t}$ represents a vector of control variables. Since the factors that affect CA choice may also affect household poverty and the farm level outcomes, the second stage outcome regressions can share the covariates included in the first stage regression. $\hat{\lambda}$ are the predicted inverse mills ratios (IMRs) derived from the multinomial logit selection equation (2.7) to capture time-varying unobservable effects. $\sigma$ is the covariance between the error terms of CA choice and the outcome equations. In addition to the IMRs, we introduce the interaction of the IMRs and year $(T)$ as $\hat{\lambda}_{i t, j} T$ based on Wooldridge (2002) for estimation of unbalanced panel data models (Kassie et al., 2017). This allows for different correlations between the idiosyncratic errors and the correlations to be different across time. $v$ represents the time-invariant unobservable factors. The parameters of interest are $\beta, \psi$ and $\sigma$.

We follow Wooldridge (2002) and Malikov and Kumbhakar (2014) to estimate pooled ordinary least squares models for the outcomes. Pooled models are preferred since selection bias correction by adding the IMR to the second stage and using standard fixed effects might lead to inconsistent estimates (Wooldridge, 2002; Kassie et al., 2017). We employ OLS for continuous outcomes equations and linear probability models (LPM) for binary outcome equations (Dercon et al., 2009; Dercon and Christiaensen, 2011; Michler and Josephson, 2017). As in the first stage multinomial logit model, we utilize the Mundlak (1978) approach to attenuate the effects of unobserved heterogeneity. To this purpose, we parameterise the time invariant unobserved variable $\left(v_{i}\right)$ by replacing it with its linear projection onto the time averages of all time-varying explanatory variables (for observations that appear in both periods) as: $v_{i}=\gamma \bar{X}_{i}+b_{i}$ with $b_{i} \sim \operatorname{IIN}\left(0, \sigma_{b}^{2}\right)$ and $E\left(b_{i} \mid \bar{X}_{i}\right)=0$. The use of the Mundlak specification to define correlated effects in both stages helps us conserve degrees of freedom (Malikov and Kumbhakar, 2014). Since the second stage outcome regressions include estimates from the first stage selection model, we correct the standard errors using bootstrapping.

The significance level of our treatment effects will not be biased due to lack of exclusion restrictions because we estimate separate outcome regressions for CA users and nonusers (Malikov and Kumbhakar, 2014; Kassie et al., 2017). However, it is often important to use exclusion restrictions in addition to those automatically generated by the nonlinearity of the IMRs obtained from the selection model. Previous stud- 
ies used past experience of extreme weather events (e.g., drought) and information sources (e.g., government extension, farmer-to-farmer extension, information from radio) as selection instruments in related impact evaluation studies (Di Falco et al., 2011; Di Falco and Veronesi, 2013; Kassie et al., 2015; Teklewold and Mekonnen, 2017). To remain within the spirit of these studies, we use community level improvement in agricultural extension services related to crop production and natural resources management as exclusion restriction. Following Di Falco et al. (2011), we test the validity of the selection instruments by performing a simple falsification test. The results confirm that the excluded variables have a significant effect on CA (significant for some of the CA practices) but do not exert any significant effect in the outcome equations (Table A.11 in Appendix A).

\section{Counterfactual Analysis and Treatment Effects}

To assess the effect of the CA technology set choice on the outcomes (the treatment effect on the treated), we estimate the expected actual (observed) outcomes and the counterfactual outcomes for a farm household that uses CA technology set $j$ with correction for selection bias and endogeneity. The actual expected outcomes are computed as:

$$
E\left(Y_{i t, J} \mid j=J\right)=X_{i t, J} \beta_{J}+\hat{\lambda}_{i t, J} \sigma_{J}+\left(\hat{\lambda}_{i t, J} T\right) \psi_{J}+\bar{X}_{i J} \gamma_{J}, j=1,2, \ldots, J
$$

where $\bar{X}_{i J}$ denotes the mean of the time-varying explanatory variables introduced to control for the effect of unobserved factors.

Similarly, the counterfactual expected value of the outcomes for farm households with a CA technology set $j$ that contains one or more CA components is given as:

$$
E\left(Y_{i t, 0} \mid j=J\right)=X_{i t, J} \beta_{0}+\hat{\lambda}_{i t, J} \sigma_{0}+\left(\hat{\lambda}_{i t, J} T\right) \psi_{0}+\bar{X}_{i J} \gamma_{0}, j=1,2, \ldots, J
$$

In equation 2.10, the parameters $\beta_{0}, \sigma_{0}, \psi_{0}$ and $\gamma_{0}$ are coefficients obtained from estimation of the outcomes without a CA technology set $(j=0)$ and the other variables are as they are defined above. Equation 2.10 represents the outcome from a CA technology set $j(j=1, \ldots, J)$ CA users would have obtained if the returns (coefficients) on their characteristics $(X, \bar{X}$, and $\hat{\lambda})$ had been the same as the returns (coefficients) on the characteristics of the non-users (Teklewold et al., 2013; Kassie et al., 2017).

The average treatment effect on the treated (ATT), which is the measure of the average effect of CA on the outcomes, is estimated taking the difference between equations 2.9 and 2.10 (Kassie et al., 2017; Khonje et al., 2018) as follows 


$$
\begin{aligned}
A T T & =E\left(Y_{i t, J} \mid j=J\right)-E\left(Y_{i t, 0} \mid j=J\right) \\
& =\left(\beta_{j}-\beta_{0}\right) X_{i t, J}+\left(\sigma_{J}-\sigma_{0}\right) \hat{\lambda}_{i t, J}+\left(\psi_{J}-\psi_{0}\right)\left(\hat{\lambda}_{i t, J} T\right)+\left(\gamma_{J}-\gamma_{0}\right) \bar{X}_{i J}
\end{aligned}
$$

The first term of equation 2.11 $\left(\left(\beta_{j}-\beta_{0}\right) X_{i t, J}\right)$ indicates the change in the outcomes due to the differences in returns to observed characteristics. The second and third terms $\left(\left(\sigma_{J}-\sigma_{0}\right) \hat{\lambda}_{i t, J}\right.$ and $\left.\left(\psi_{J}-\psi_{0}\right)\left(\hat{\lambda}_{i t, J} T\right)\right)$ indicate the change in the outcomes due to differences in returns that attribute to time-variant unobserved characteristics. The last term $\left(\left(\gamma_{J}-\gamma_{0}\right) \bar{X}_{i J}\right)$ is attributed to outcome changes because of differences in time-invariant unobservables.

\subsection{DATA AND DESCRIPTIVE STATISTiCS}

\subsubsection{Household and Rainfall Data}

The data come from the Ethiopian Socioeconomic Survey (ESS) administered through the Living Standards Measurement Study-Integrated Surveys on Agriculture (LSMSISA) initiative of the World Bank in collaboration with the Central Statistical Authority of Ethiopia.7 The household survey collects detailed information on household socioeconomic characteristics, income sources, non-agricultural household enterprise, household assets, household consumption expenditure, shocks and coping strategies. The agriculture survey collects information on land holdings, agricultural inputs, crop production and disposition patterns and livestock ownership. Moreover, the ESS collects information on extension services related to crop production and natural resources management at the community level. Both the households and their plots are georeferenced using global positioning system (GPS) that enables inclusion of relevant biophysical factors such as rainfall and soil in our analysis.

The LSMS-ISA provides high-quality household consumption data for poverty analysis (Farris et al., 2017). We utilize information on socioeconomic variables such as farmer characteristics (e.g. age, gender, education, household size), wealth (land holding, livestock wealth, asset holding, credit access), farm management (e.g. input use, plot characteristics, etc), biophysical factors (e.g. soil, temperature, rainfall) and the enabling environment (e.g. markets, extension services, proximity to road) as controls in the analysis. The panel nature of the data set allows us to study variation in CA use and household poverty, both of which are important considerations for policy making. While the ESS has three waves (2011/12, 2013/14 and 2015/16), we do not use the 2011/12 wave since no information is collected about crop residue retention and minimum tillage. Therefore, this chapter is based on data from the latest two waves

7 Details of the survey including sample size, sampling methods, data and other supporting materials are provided in the website: www.worldbank.org/lsms-isa. 
(2013/14 and 2015/16) with a focus on rural Ethiopia. Attrition for the rural household sample is $1.5 \%$ across the two waves. After thorough data cleaning and exclusion of observations with missing values, final analysis is undertaken with an unbalanced panel of 6,102 rural households.

We extract historical rainfall data from the Climate Hazards Group InfraRed Precipitation with Station data (CHIRPS), a thirty year quasi-global rainfall dataset that spans $50^{\circ} \mathrm{S}-50^{\circ} \mathrm{N}$. CHIRPS incorporates $0.05^{\circ}$ resolution satellite imagery with insitu station data to create a gridded rainfall time series (Funk et al., 2015; Michler et al., 2018). We make use of the geographical coordinates for the village boundaries from the LSMS-ISA data to take the average rainfall for the day (and months) within the village from 1981 to 2014. Then, we aggregate the village level daily and monthly rainfall data to the annual and seasonal levels. From the rainfall data, we compute the historical average and standard deviation of rainfall to capture the short and long term climate variability. The amount of rainfall during the growing season preceding the survey year is also included as proxy for water stress or availability. The rainfall variables help to control for the effect of farmers' risk profile and expectations on CA use.

\subsubsection{Conservation agriculture use pattern}

A difficulty in empirical studies on the farm level economics of CA is deciding which practice(s) to count as CA (Pannell et al., 2014; Michler et al., 2018). In this study, the three pillars of CA considered are minimum or reduced tillage $(\mathrm{T})$, crop residue retention or mulching $(\mathrm{R})$ and cereal-legume intercropping $(\mathrm{C})$. We define minimum tillage as a binary variable taking a value of $I$ if the households uses either zero or reduced tillage (only one plough pass) on at least one of the plots (Kassie et al., 2015). Crop residue retention, another anchor of CA, is defined as a dummy variable taking value of 1 if the household leaves any crop residue/mulch on the plot surface. ${ }^{8}$ Cereal-legume intercropping is another essential part of CA systems and a climaterisk reduction strategy. We exploit the crop level information to create an indicator for cereal-legume intercropping which is defined as whether the household cultivates cereals with legume crops on at least one plot. 9 Then, we generate a multinomial choice variable by categorizing households according to their adoption of the $3 \mathrm{CA}$ practices in isolation and/or in combination. This leads to 8 possible CA technology set choice. Conventional farming or traditional cultivation practices are defined as everything else other than the 3 CA practices (Michler et al., 2018). Our pragmatic approach, although not ideal, is in line with previous literature (Pannell et al., 2014; Arslan et al., 2014). More important, we adopt a more practical definition of CA given

8 Crop residue retention at plot level is about $4 \%$. Less than $1 \%$ of the households report that $35 \%$ or more of their plots are covered with crop residues or mulch.

9 Since we do not have (sufficient) data about the crops cultivated on each plot in the previous season, we are not able to create an indicator for cereal-legume or maize-legume rotation. 
the context of Ethiopia (Marenya et al., 2015; Tessema et al., 2015; Teklewold and Mekonnen, 2017).

Table 2.1: Pattern of CA combinations adoption (\%)

\begin{tabular}{lccc}
\hline \hline \multirow{2}{*}{$\begin{array}{l}\text { sA } \\
\text { sets }\end{array}$} & \multicolumn{3}{c}{ Frequency $(\%)$} \\
\cline { 2 - 4 } & 2013 & 2015 & Pooled \\
\hline None $\left(T_{0} R_{0} C_{0}\right)$ & 36.42 & 51.01 & 43.66 \\
Minimum tillage only $\left(T_{1} R_{0} C_{0}\right)$ & 50.8 & 32.41 & 41.67 \\
Crop residue retention only $\left(T_{0} R_{1} C_{0}\right)$ & 0.98 & 2.44 & 1.70 \\
Cereal-legume intercropping only $\left(T_{0} R_{0} C_{1}\right)$ & 2.86 & 3.04 & 2.95 \\
Min. tillage \& crop residue only $\left(T_{1} R_{1} C_{0}\right)$ & 2.11 & 5.45 & 3.77 \\
Min. tillage \& cereal-legume intercrop only $\left(T_{1} R_{0} C_{1}\right)$ & 6.41 & 4.66 & 5.54 \\
Crop residue \& cereal-legume intercrop only $\left(T_{0} R_{1} C_{1}\right)$ & 0.23 & 0.30 & 0.26 \\
Comprehensive CA (all 3 practices) $\left(T_{1} R_{1} C_{1}\right)$ & 0.20 & 0.69 & 0.44 \\
\hline \hline
\end{tabular}

Note: Each set consists of a binary variable for the CA practices - minimum tillage (T), crop residue retention (R) and cereal-legume intercropping (C) where the subscript 1 shows use and o denotes nonuse of the particular technology set. The sample sizes are 3,075 and 3,027 for 2013 and 2015, respectively. The proportion of households using the CA practices (in contrast to the mutually exclusive category presented here) over the two periods along with proportion different test is provided in table A.I (Appendix A).

Table 2.I summarizes the use pattern of CA over the two periods. After about 20 years of promotion, the adoption of the CA practices in Ethiopia is low and uneven. The proportion of households that practice minimum tillage only significantly diminished from $51 \%$ in 2013 to about $32 \%$ in 2015 . The adoption rates are comparable with the study by Tsegaye et al. (2008) that report a $57 \%$ adoption rate of a component or combination of conservation tillage technology in Oromia region of Ethiopia. The significant decrease in minimum tillage use is an indication of unsustained adoption (Giller et al., 2009; Pannell et al., 2014). The percentage of households that practice crop residue retention or mulching only has increased from about $1 \%$ to $2.4 \%$ over the panel period. However, the adoption rate is low possibly due to the alternative uses of crop residues in the Ethiopian crop-livestock mixed farming systems (Jaleta et al., 2015; Marenya et al., 2015; Tessema et al., 2015). The proportion of households who practice cereal-legume intercropping only is low and remains stable at about $3 \%$. This indicates that monocropping is still a dominant cropping system in Ethiopian farming systems (Jirata et al., 2016). Our data suggest that Ethiopian smallholder farmers preferentially adopt minimum tillage while crop residue retention and cereallegume intercropping lagged behind. The plausible reason could be the preferential promotion of minimum tillage by different stakeholders in the country (Jirata et al., 2016; Teklewold and Mekonnen, 2017). 
What is even more surprising in our data is that the adoption of the different combinations of the CA practices is very low (table 2.1). The proportion of households who practice the combination of minimum tillage and crop residue retention only (also called conservation tillage) increased from about $2.1 \%$ in 2013 to $5.5 \%$ in 2015 . The percentage of households who practice the combination of minimum tillage and cereal-legume intercropping only falls from $6.4 \%$ to $4.7 \%$ during the same period. The adoption of a combination of crop residue retention and cereal-legume intercropping is less than $1 \%$ in both periods. Although adoption of a comprehensive CA package that includes the full suite is theorized to provide better financial returns (Knowler and Bradshaw, 2007), the percentage of farmers practicing all components of CA (the most comprehensive CA package) is less than $1 \%$. Previous studies also show that the adoption of the full CA package in a smallholder farming context is rare and often farmers adopt one or two individual components (Giller et al., 2009; Arslan et al., 2014; Tessema et al., 2015). The primary constraints to CA adoption include the high opportunity cost associated with the alternative use of crop residues, labor constraints and the high costs of herbicides (Arslan et al., 2014; Tessema et al., 2015; Jaleta et al., 2015; Teklewold and Mekonnen, 2017). Since the number of households that practice a combination of crop residue retention and cereal-legume intercropping only $\left(T_{0} R_{1} C_{1}\right)$ and the combination of the three practices $\left(T_{1} R_{1} C_{1}\right)$ is extremely low to allow a joint analysis of the combination of these practices and produce credible estimates, our econometric model excludes the two CA categories. Estimation based on combining different categories might also makes identifying the mechanism of impact less clear. However, we produce the impact estimates by combining the two categories with other categories as a robustness check and to minimize sample selection. The results remain similar with those obtained by dropping the two categories (see tables A.12, A.13 and A.14 in Appendix A for combined categories and results).

Another interesting feature of CA use pattern is transition or switching behaviour of households in and out of use during the two periods. To describe the transitions of households across CA practices over the two periods, we split the CA use history for each practice and combinations into dummies. We define a "stayer" as a farmer (household) that uses the CA practice in both 2013 and 2015. A "joiner" is defined as a farmer who does not use the particular CA practice in 2013 but does in 2015. Similarly, a "leaver" is a farmer who practices the particular CA practice in 2013 but not in 2015. A "nonuser" is a household that does not use any of the CA practices in both periods. The transitions of each CA practice in the sample data is provided in table A.2 (Appendix A). The results show that about 32\% of the sample households used minimum tillage in both periods (stayers) and about $39 \%$ of the households switch in and out of minimum tillage use over 2013 and 2015. The use of the other CA practices in particular the combinations of CA practices is low and characterized by low transitions of households in and out of use. Such switching behaviour could be due to differences in observed and unobserved time-invariant and time-variant factors. 
Although we do not explicitly model CA transitions, we take account of switching behaviour and related issues in our empirical estimations.

\subsubsection{Household poverty}

Household poverty is estimated using a monetary measure of household welfare. In this study, aggregate consumption expenditure is used to base the calculation of household poverty. The total household consumption expenditure is first calculated by aggregating the estimated total value of food and non-food expenditures. ${ }^{10}$ The aggregate consumption expenditure is adjusted for differences in the nutritional or calorie requirement of different household members by dividing it with an adult equivalence scale. The per adult equivalent nominal consumption expenditure is deflated using the consumer price index (CPI) obtained from Central Statistical Authority of Ethiopia to account for the spatial and temporal differences in the costs-of-basic needs.

Poverty indices are computed based on the popular Foster-Greer-Thorbeck (FGT) method (Foster et al., 1984):

$$
p_{\alpha}=\frac{1}{N} \sum_{i=1}^{q}\left[\frac{z-c_{i}}{z}\right]^{\alpha}
$$

where $z$ denotes the national poverty line established by the Ministry of Finance and Economic Development (MOFED) of Ethiopia, $c_{i}$ is the per adult equivalent consumption expenditure estimated from the survey data for the $i^{\text {th }}$ poor household, $N$ is the sample size and $q$ is the number of households whose consumption expenditure is below the national poverty line. Three poverty indices are computed by varying the inequality aversion parameter, $\alpha$. When $\alpha=0$, the formula reduces to the headcount ratio that measures the proportion of households below the national poverty line. When $\alpha=1$, it provides the poverty-gap that shows the intensity or extent of poverty as it indicates how far the poor are from the national poverty line. A value of $\alpha=2$ provides a measure of severity of poverty or the degree of inequality among the poor.

In our sample, the proportion of households below the national poverty line significantly increased from about $41 \%$ in $2013 / 14$ to $46 \%$ in $2015 / 16$. Recent studies by Zeng et al. (2015), Michler and Josephson (2017), and Verkaart et al. (2017) also report comparable rates. To better understand how the incidence of poverty changes over

10 The value of food consumption is computed as the total value of consumption from home production, market purchases and gifts estimated using the median price calculated at the lowest geographical unit. The median prices are calculated at the lowest geographical unit for which there are at least 1o price observations. If there are less than 1o price observations for that item at the EA, the next level up is used. The geographical levels used, in ascending order, are EA, Kebele, Woreda, zone and region and national. 
the two periods, we present poverty transition matrix analysis. The results show the presence of a significant movement of the sample households in and out of poverty over the two periods. In fact, about $66 \%$ of the households who were non-poor in $2013 / 14$ remain above the national poverty line in $2015 / 16$, and about $63 \%$ of the households that were poor in 2013/14 remain poor in 2015/16. This is an indication of high poverty persistence in rural Ethiopia. Interestingly, about $37 \%$ of the poor in $2013 / 14$ moves out of poverty in $2015 / 16$, whereas $34 \%$ of the non-poor also moves into poverty. Results of the transition analysis show a dramatic mobility of the rural households into and out of poverty over the two periods. In this study, we only have two observations per household. Therefore, it is difficult to find informative measures of household poverty dynamics and to study how poverty responds to CA adoption over time. Table 2.2 provides the mean values of the household poverty measures. The descriptive statistics and bivariate analysis results show that non CA households are better off than CA users.

\subsubsection{Mechanisms - farm level economic outcomes}

While reducing poverty is not, strictly speaking, a direct product of CA adoption, it can be thought of as an extension of the productivity increasing, cost reducing and downside risk mitigating effects of CA. To provide evidence on the possible farm level pathways through which CA impacts household poverty, we estimate the impact of CA on farm productivity, cost of production, and risk of crop failure. Farm productivity is measured as net crop income per hectare. While crop yield per area is the most commonly used indicator for farm productivity, it is less attractive in multiplecrop economies. Since farm households are more concerned with maximization of economic value, the value of farm production or crop income could be a better indicator to reflect the ultimate impacts of farmers' decisions (such as CA adoption) on their welfare. We take the value of crop harvested instead of the value of crop sold to measure value of production using prices at the most appropriate transaction level (farm gate or community levels based on data availability). Crop production expenditures are measured as the sum of land rental values, cost of inputs including seeds, fertilizer, and labor hired for land preparation and harvest. To arrive at a measure of crop income, we deduct total production expenses from the value of production. To get a measure of the risk of crop failure, we generate a dummy variable which takes a value of 1 if the household reports any crop failure or damage in the agricultural season. 


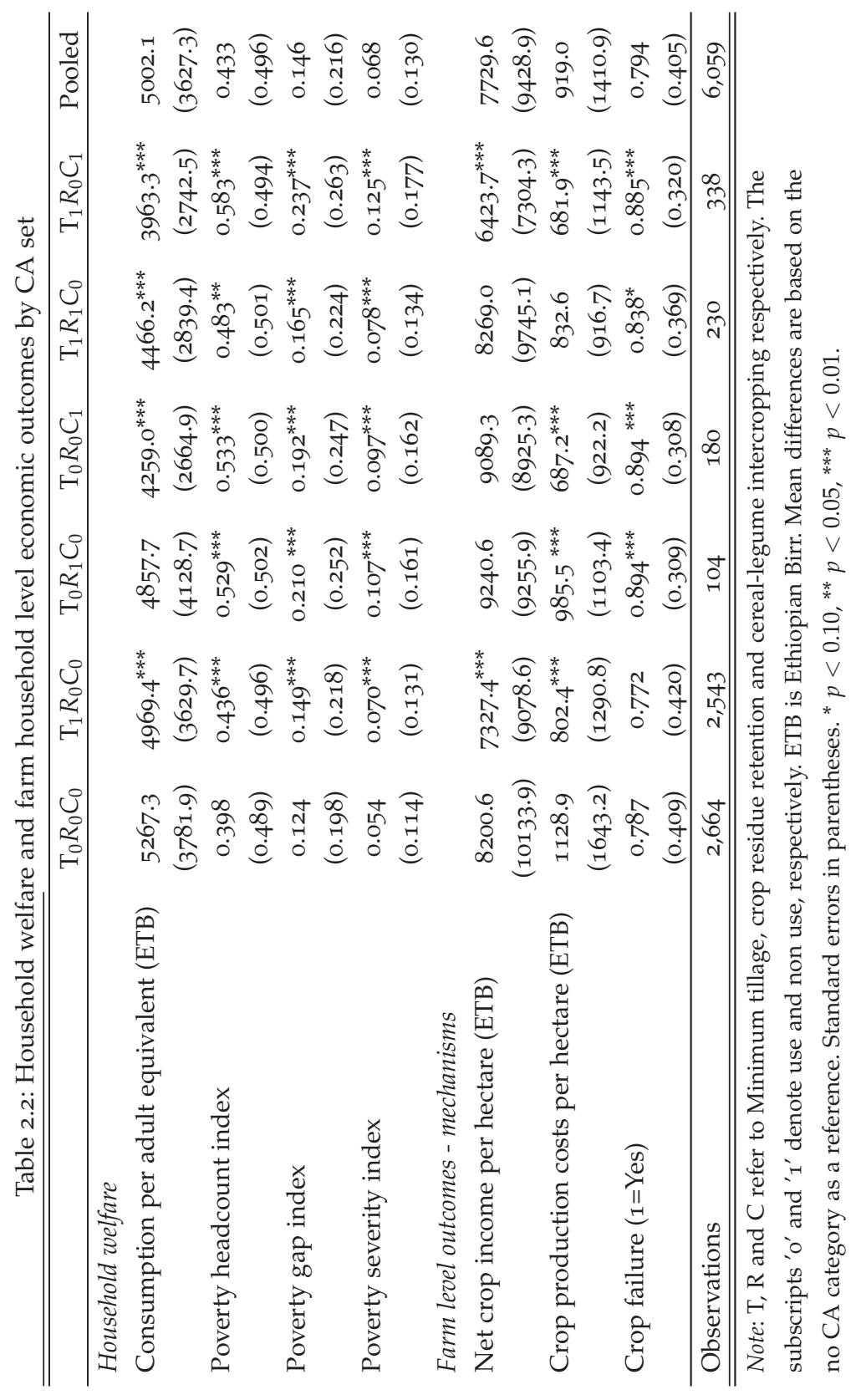


Table 2.2 shows that there is a considerable difference in crop income and cost of production per hectare between CA and non CA households. The simple bivariate analysis shows that the average net crop income per hectare for the pooled sample is 6,423.70 - 9,240.60 Ethiopian Birr (ETB). The per hectare cost of production also ranges between 681.90 - 1,128.90 ETB. CA users tend to have lower cost of production than non CA households. Cereal-legume intercropping is the cheapest CA technology set followed by combination of minimum tillage and cereal-legume intercropping. Households practicing almost all CA components report higher crop failure compared to non CA households.

\subsection{ECONOMETRIC RESULTS}

In this section, we first discuss the first stage results of the panel data endogenous switching multinomial logit model which provides estimates for the determinants of CA adoption. This is followed by discussion of the impact of CA on poverty and the farm level economic outcomes.

\subsubsection{Drivers of CA use}

The parameter estimates (marginal effects) of the first stage multinomial endogenous switching regression which allow us to explore the main determinants of CA adoption are given in table A.4 (Appendix A). The results provide information on the drivers of CA adoption. The Wald test result $\left(\chi^{2}=1612.35\right.$, significant at $1 \%$ level $)$ suggests that the explanatory variables included in the model provide a good explanation of CA choice behaviour. The Mundlak variables (individually and jointly) are significant in the multinomial logit model. This indicates the presence of some sort of unobserved heterogeneity and justifies the use of pooled multinomial logit model with farmer's heterogeneity.

Household (farmer) characteristics play a minimal role in determining CA use. Household size (measured in adult equivalents) increases the probability of cereallegume intercropping with no significant effect on the other CA pillars. Land holding is found to be positively correlated with the probability of crop residue retention and cereal-legume intercropping only. Access to credit is positively associated with crop residue retention. In rural areas where crop residues are one source of household income, credit access may relax liquidity constraint and allows retention of crop residues as mulch. Age of the household head is negatively associated with adoption of minimum tillage only. This could be attributed to impatience, risk aversion and technology mistrust behaviour (Bezu et al., 2014; Verkaart et al., 2017). Arslan et al. (2014) also find a negative correlation between age of the household head and conservation farming adoption in Zambia. Agricultural asset wealth reduces the probability of crop residue retention but increases the probability of adopting a combination of 
minimum tillage with cereal-legume associations. This finding is consistent with that of Asfaw et al. (2016a) that also find a negative correlation between agricultural asset wealth and crop residue retention in Niger. Surprisingly, we find little evidence regarding the role of livestock holding on the probability of CA use. We find no evidence for the role of gender and education of the household head in determining CA use decision.

We explore the role of extension service or advice on crop production and natural resources management in determining CA use. While increase in the quality of advice on crop production reduces the probability of crop residue retention, advice on natural resources management increases the use of both crop residue retention and conservation tillage. The positive and significant effect on conservation tillage is corroborated by previous findings (Arslan et al., 2014; Di Falco and Veronesi, 2013). The adoption of minimum tillage and the combination of minimum tillage with cereallegume intercropping is positively associated with distance to the nearest market. This could be due to the desire for food self-sufficiency, particularly in areas where markets cannot be easily accessed. We find distance to the nearest major road to be negatively associated with adoption of cereal-legume intercropping only. Since proximity to major road is often associated with improved transportation and information, remote households may lack information about the benefits of CA. CA use is negatively associated with input price increase. This suggests that increase in price of agricultural inputs deters adoption of CA.

Farm characteristics and soil nutrient availability are also found to be important determinants of CA use. Interestingly, farm households who face minimal soil nutrient constraints are less likely to adopt minimum tillage. Furthermore, the adoption of crop residue retention and conservation tillage is negatively correlated with the number of plots with good fertility. The results suggest that households are more likely to adopt these CA practices as a strategy to alleviate soil nutrient constraints. This finding is in line with results from previous studies (Di Falco and Veronesi, 2013; Arslan et al., 2014; Asfaw et al., 2016a). The use of organic fertilizer increases the probability of minimum tillage adoption but reduces the probability of adopting conservation tillage. This could be possibly due to potential complementarity or substitutability between organic fertilizer and CA practices.

Consistent with the literature, we find that most of the climatic variables have a significant effect on CA choice. An increase in monthly temperature positively and significantly affects all CA practices except conservation tillage. Although the rainfall level in the previous agricultural season does not exert significant effect on CA adoption, an increase in the historical average rainfall reduces the adoption of cereallegume intercropping and conservation tillage. More importantly, long-term rainfall variability measured using standard deviation increases the probability of adoption of crop residue retention, cereal-legume intercropping and the combination of minimum 
tillage with cereal-legume intercropping. This suggests that households who receive higher annual rainfall do not have an incentive to adopt CA, an indication that CA is an attractive strategy in times of rainfall stress. The statistical significance of the relationship between the climatic variables and the adoption of CA suggests that CA could be a strategy adopted by farmers in response to climatic variability (Di Falco and Veronesi, 2013; Arslan et al., 2014; Teklewold and Mekonnen, 2017).

\subsubsection{Impacts of $\mathrm{CA}$ on Poverty}

We estimate the impact of CA on three household poverty indices: headcount, poverty gap, and poverty severity. Results from the econometric models show that some of the time averages, the selection correction terms, and interaction of the selection bias correction terms with time are significant in most of the outcome equations. This is an indication of the presence of selection bias and unobserved heterogeneity in the CA use decisions. It also justifies the appropriateness of the selected empirical strategy to attenuate endogeneity. Since the interest is on the impact estimates of CA on poverty, the second stage outcome regressions are not discussed here. The second stage regressions estimates for the three poverty indices are provided in Appendix A (see Tables A.5, A.6 and A.7). Table 2.3 provides the actual and counterfactual outcomes and the treatment effect estimates (ATT) from the panel data multinomial endogenous switching regression.

Table 2.3: Impact of CA on household poverty

\begin{tabular}{|c|c|c|c|c|c|c|c|c|c|}
\hline \multirow{2}{*}{$\begin{array}{l}\text { CA } \\
\text { set }\end{array}$} & \multicolumn{3}{|c|}{ Poverty headcount } & \multicolumn{3}{|c|}{ Poverty gap } & \multicolumn{3}{|c|}{ Poverty severity } \\
\hline & $\mathrm{A}$ & $\mathrm{C}$ & $\operatorname{ATT}(\mathrm{A}-\mathrm{C})$ & A & $\mathrm{C}$ & $\operatorname{ATT}(\mathrm{A}-\mathrm{C})$ & $\mathrm{A}$ & $\mathrm{C}$ & $\operatorname{ATT}(\mathrm{A}-\mathrm{C})$ \\
\hline Minimum tillage & 0.436 & 0.439 & -0.004 & 0.149 & 0.154 & $-0.005^{*}$ & 0.070 & 0.075 & $-0.005^{* * *}$ \\
\hline Crop residue retention & 0.529 & 0.388 & $0.141^{* *}$ & 0.210 & 0.153 & $0.057^{* *}$ & 0.107 & 0.067 & $0.040^{* *}$ \\
\hline Cereal-legume intercropping & 0.533 & 0.598 & $-0.065^{*}$ & 0.192 & 0.230 & $-0.038^{*}$ & 0.097 & 0.123 & $-0.026^{*}$ \\
\hline Min. tillage \& crop residue & 0.483 & 0.408 & $0.075^{* * *}$ & 0.165 & 0.149 & $0.018^{*}$ & 0.078 & 0.067 & $0.010^{*}$ \\
\hline Min. tillage \& cereal-legume & 0.580 & 0.783 & $-0.203^{* * *}$ & 0.237 & 0.334 & $-0.097^{* * *}$ & 0.125 & 0.175 & $-0.050^{* * *}$ \\
\hline
\end{tabular}

Note: We report actual outcome with CA (A), counterfactual outcome without CA scenario (C) and difference in actual and counterfactual outcomes as impact (ATT). We do not report standard errors to save space. ${ }^{*} p<0.10,{ }^{* *} p<0.05,{ }^{* * *} p<0.01$.

Estimates from the panel data endogenous switching regression show that minimum tillage individually does not exert any significant effect on poverty headcount. However, crop residue retention increases the probability of being poor. Cereal-legume intercropping reduces the probability that a household falls below the national poverty line by 6.5 percentage points. The combined use of minimum tillage and crop residue retention, also known as conservation tillage, also increases the probability of being poor by about 7.5 percentage points. An interesting finding is that, the combined use of minimum tillage with cereal-legume intercropping reduces the probability of be- 
ing poor by 20.3 percentage points. The findings show that CA indeed has a povertyreducing effect. However, this role depends on the type of CA practice.

Table 2.3 also provides evidence on the link between CA and other poverty indices. An interesting result is the significant effect of minimum tillage in reducing both the poverty gap and poverty severity. However, crop residue retention and the combination of crop residue retention and minimum tillage appear to be a least attractive option for reducing poverty gap and poverty severity in Ethiopia. Cereal-legume intercropping and more importantly the combination of minimum tillage with cereallegume intercropping unambiguously reduce both the poverty gap and poverty severity. The totality of our findings suggests that having crop residues in the CA technology set is less likely to help households grow out of poverty at least in the short run.

Studies from SSA emphasize that the benefits of CA are context specific (Giller et al., 2009; Pannell et al., 2014; Arslan et al., 2015). Pannell et al. (2014) argue that CA would be more attractive to households with better resource endowments and with longer planning horizons or lower discount rates. There is also a possibility that some households are positioned well and have the capacity to benefit from CA while others do not (Dercon and Christiaensen, 2011; Verkaart et al., 2017). In this study, we test whether CA generates differential effect on poverty for households with different resource endowments and exposure to rainfall shocks (Table 2.4). Differences in resource endowments determines differences in risk tolerance and the opportunity cost of climate risk for households (Hansen et al., 2018). Analyzing the differential impacts of CA based on differences in exposure to rainfall endowment (rainfall stress or rainfall shortage and rainfall abundant or rainfall surplus) could help to explain whether CA reduces rural poverty through its resilience benefits. ${ }^{11}$

11 We follow Ward and Shively (2015) and Michler et al. (2018) to calculate rainfall shock. Rainfall shortage is calculated as: $\underline{\mathrm{r}}_{i t}=\left|\frac{R_{i t}-\bar{R}_{i}}{\sigma_{i t}}\right|$ if $\mathrm{R}_{i t}<\bar{R}_{i}, 0$ otherwise. A measure of rainfall surplus is: $\bar{r}_{i t}=\left|\frac{R_{i t}-\bar{R}_{i}}{\sigma_{i t}}\right|$ if $\mathrm{R}_{i t}>\bar{R}_{i}, 0$ otherwise. $\mathrm{R}_{i t}$ is the yearly rainfall, $\bar{R}_{i}$ is the historical average (1981-2014), and $\sigma_{i t}$ is the standard deviation of rainfall during the same period. 
Table 2.4: Effects of CA on poverty headcount by rainfall and household wealth

\begin{tabular}{|c|c|c|c|c|c|c|}
\hline \multirow{2}{*}{$\begin{array}{l}\text { CA } \\
\text { set }\end{array}$} & \multicolumn{2}{|c|}{ Rainfall shock } & \multicolumn{2}{|c|}{ Livestock holding } & \multicolumn{2}{|c|}{ Land holding } \\
\hline & shortage & surplus & poor & non-poor & poor & non-poor \\
\hline Minimum tillage & $-0.022^{* * *}$ & 0.013 & -0.012 & 0.003 & 0.002 & 0.008 \\
\hline Crop residue retention & 0.104 & 0.202 & 0.100 & $0.147^{*}$ & 0.032 & $0.216^{* * *}$ \\
\hline Cereal-legume intercropping & -0.061 & -0.070 & -0.098 & $-0.081^{*}$ & $-0.184^{*}$ & 0.048 \\
\hline Min. tillage \& crop residue & 0.031 & $0.189^{* * *}$ & -0.019 & $0.127^{* * *}$ & 0.039 & $0.108^{* * *}$ \\
\hline Min. tillage \& cereal-legume & $-0.206^{* * *}$ & $-0.196^{* * *}$ & $-0.196^{* * *}$ & $-0.206^{* * *}$ & $-0.280^{* * *}$ & $-0.095^{* * *}$ \\
\hline Observations & 3,914 & 2,188 & 1,971 & 4,131 & 1,924 & 4,178 \\
\hline
\end{tabular}

Note: We report only the ATT (difference in actual outcome and counterfactual outcome) to save space. Livestock and land poor are households with livestock holdings (in TLU) and land holdings (hectares) in the lowest (first) quartile of the distribution and non-poor are those with livestock holdings and land holdings in the second, third and fourth quartiles; ${ }^{*} p<0.10,{ }^{* *} p<0.05,{ }^{* * *} p<0.01$.

The results disaggregated by rainfall endowments show that the poverty-reducing effects of CA, particularly minimum tillage, are more pronounced in areas that experience rainfall shortage than in areas that have abundant rainfall. The combination of minimum tillage and cereal-legume intercropping reduces poverty regardless of differences in rainfall endowments. The results are in compliance with findings from previous studies (Lobell et al., 2008; El-Shater et al., 2016). Teklewold and Mekonnen (2017) also show that reduced tillage provides higher farm returns in drier areas in Ethiopia. While crop residue retention and cereal-legume intercropping alone do not have any significant effect on household poverty in areas with different rainfall endowments, the combined use of minimum tillage and crop residue retention increases the probability of being poor in areas experiencing rainfall surplus. This is an indication that conservation tillage is not an attractive CA option in these areas and this could be due to its potential yield penalty (Michler et al., 2018). Pannell et al. (2014) also indicate the possible cases of short-term yield depression associated with the use of reduced tillage and mulching.

Disaggregating the results by different wealth (land and livestock holding) groups provides some interesting findings. As expected, crop residue retention and conservation tillage do not increase the likelihood of being poor for households with low livestock and land holdings (those at the lowest quartiles). However, it increases the probability of falling below the poverty line for households with more livestock and land holdings. This is evidence that relatively rich households do not have an incentive either to leave crop residues as mulch on their farms or to combine minimum tillage with crop residue retention. We find that cereal-legume intercropping has marginal poverty-reducing effect among livestock non-poor and land-poor households. This latter result is interesting as cereal-legume intercropping is itself a land-saving practice in land-constrained circumstances. The results show that this CA pillar has signifi- 
cant poverty reducing effects for households with land holdings at the lowest quartile (poor households) compared to richer households. The unambiguously negative and significant poverty reducing effect of the combination of minimum tillage with cereal-legume intercropping makes it the most attractive CA option for reducing rural poverty and hence improving rural prosperity in Ethiopia.

\subsubsection{Impact Pathways}

To help elucidate the potential mechanisms through which CA affects poverty, in the following section, we empirically explore if CA also has significant effect on crop income, costs of production and risk of crop failure.

\subsubsection{Farm productivity effects of $C A$}

The estimates of the multinomial endogenous switching regression model for farm productivity measured as net crop income per hectare is provided in Table 2.5. The results show that minimum tillage increases net crop income per hectare by about 2,724 Ethiopian Birr (ETB). While crop residue retention reduces the per hectare crop income by about 5,024 ETB, cereal-legume intercropping alone or conservation tillage do not have any significant effect on crop income.

Table 2.5: Impact of CA on crop income per hectare

\begin{tabular}{lccc}
\hline \hline CA set & $\begin{array}{c}\text { Actual } \\
\text { Outcome }\end{array}$ & $\begin{array}{c}\text { Counterfactual } \\
\text { Outcome }\end{array}$ & $\begin{array}{c}\text { Impact } \\
(\mathrm{ATT})\end{array}$ \\
\hline Minimum tillage & $7,528.15$ & $4,804.19$ & $2,723.96^{* * *}(162.62)$ \\
Crop residue retention & $9,781.43$ & $14,804.94$ & $-5,023.51^{* * *}(1432.79)$ \\
Cereal-legume intercropping & $9,160.04$ & $9,366.14$ & $-206.11(670.59)$ \\
Minimum tillage \& crop residue & $8,559.12$ & $8,640.52$ & $-81.40(640.49)$ \\
Minimum tillage \& cereal-legume & $6,418.52$ & $1,210.90$ & $5,207.62^{* * *}(847.61)$ \\
\hline \hline
\end{tabular}

Note: ATT stands for average treatment effect on the treated and computed as the difference in actual and counterfactual outcomes. We do not report standard errors for actual and counterfactual outcomes to save space. ${ }^{*} p<0.10,{ }^{* *} p<0.05,{ }^{* * *} p<0.01$.

Interestingly, we find that CA generates higher farm productivity benefits when minimum tillage is used in combination with cereal-legume intercropping, increasing the average crop income by about 5,208 ETB per hectare for users compared to the counterfactual scenario of non use. The significant farm productivity or crop income effects of CA are consistent with the findings of previous studies (Jaleta et al., 2016; Khonje et al., 2018). Farris et al. (2017) also demonstrate that CA reduces poverty in Uganda by increasing farm profits for the poor households. Recently, Khonje et al. (2018) find that CA increases maize yield, maize income and household income in 
Zambia when adopted in isolation as well as in combination with improved seeds. Our finding is also in agreement with previous studies that document the positive welfare impact of cereal-legume intercropping and the combination of minimum tillage with cereal-legume intercropping (Mason and Smale, 2013; Zeng et al., 2015).

\subsubsection{Impact of CA on cost of production}

The estimates for the impact of CA on the cost of production are provided in Table 2.6. With the exception of crop residue retention, we find that all CA practices (when used in isolation) and a combination of minimum tillage with crop residue and cereallegume intercropping have significant production cost reducing effects. Part of the reason for the significant cost-reducing effects of minimum tillage could be the labor demand reducing effect of minimum tillage(Knowler and Bradshaw, 2007; Teklewold et al., 2013; Teklewold and Mekonnen, 2017). Cereal-legume intercropping also plays a pivotal role in the control of crop pests, diseases and weeds, and legumes also provide nitrogen to cereal crop production through their nitrogen-fixing role. Thus, cereal-legume intercropping could reduce the demand for pesticides and chemical fertilizer, inputs that often contribute the highest costs of crop production (Teklewold et al., 2013; Kassie et al., 2017). Nevertheless, crop residue retention involves costs for herbicides and labor for weed control, particularly when combined with minimum tillage.

Table 2.6: Impact of CA on cost of production

\begin{tabular}{lccc}
\hline \hline CA set & $\begin{array}{c}\text { Actual } \\
\text { Outcome }\end{array}$ & $\begin{array}{c}\text { Counterfactual } \\
\text { Outcome }\end{array}$ & $\begin{array}{c}\text { Impact } \\
\text { (ATT) }\end{array}$ \\
\hline Minimum tillage & 803.46 & $1,288.25$ & $-484.79^{* * *}(19.03)$ \\
Crop residue retention & 985.45 & 815.38 & $170.08(157.43)$ \\
Cereal-legume intercropping & 687.18 & $1,454.38$ & $-767.20^{* * *}(146.07)$ \\
Minimum tillage \& crop residue & 832.56 & 998.06 & $-165.50^{* * *}(44.43)$ \\
Min. tillage \& cereal-legume intercropping & 683.11 & $1,092.10$ & $-409.00^{* * *}(49.83)$ \\
\hline \hline
\end{tabular}

Note: ATT stands for average treatment effect on the treated and computed as the difference in actual and counterfactual outcomes. We do not report standard errors for actual and counterfactual outcomes to save space. ${ }^{*} p<0.10,{ }^{* *} p<0.05,{ }^{* * *} p<0.01$.

The lack of significant effect of crop residue retention on the cost of production (although not expected as discussed in Pannell et al. (2014)), coupled with its negative impact on crop income, could explain why it is not an attractive strategy for reducing rural poverty at least in the short run. 


\subsubsection{Impact of CA on risk of crop failure}

In areas plagued by low rainfall and poor soil fertility that increase the level of environmental stress, CA can improve the adaptive capacity or resilience of households through reducing the risk of crop failure (Di Falco and Chavas, 2008). We find that the adoption of minimum tillage in isolation reduces the probability of risk of crop failure by 1.6 percentage points compared to the counterfactual scenario (table 2.7). However, crop residue retention, cereal-legume intercropping and conservation tillage have no significant impact on the probability of crop failure. The results show that the combination of minimum tillage and cereal-legume intercropping has the highest impact on reducing the risk of crop failure (6.2 percentage points). Previous studies also demonstrate that the risk-reducing (and other) benefits of CA are mainly driven by the interaction of minimum tillage with cereal-legume associations (Thierfelder et al., 2013; Kassie et al., 2015). Arslan et al. (2015) also find that legume intercropping reduces the prevalence of very low yields and yield shortfalls in Zambia.

Table 2.7: Impact of CA on risk of crop failure

\begin{tabular}{lccc}
\hline \hline CA components & $\begin{array}{c}\text { Actual } \\
\text { Outcome }\end{array}$ & $\begin{array}{c}\text { Counterfactual } \\
\text { Outcome }\end{array}$ & $\begin{array}{c}\text { Impact } \\
\text { (ATT) }\end{array}$ \\
\hline Minimum tillage & 0.773 & 0.789 & $-0.016^{* * *}$ \\
Crop residue retention & 0.894 & 0.882 & 0.012 \\
Cereal-legume intercropping & 0.894 & 0.906 & -0.011 \\
Minimum tillage \& crop residue & 0.838 & 0.815 & 0.023 \\
Minimum tillage \& cereal-legume intercropping & 0.887 & 0.949 & $-0.062^{* * *}$ \\
\hline \hline
\end{tabular}

Note: ATT stands for average treatment effect on the treated and computed as the difference in actual and counterfactual outcomes. We do not report standard errors for actual and counterfactual outcomes to save space. ${ }^{*} p<0.10,{ }^{* *} p<0.05,{ }^{* * *} p<0.01$.

Overall, the results strongly suggest that the main mechanisms for poverty-reducing effects of CA (particularly minimum tillage, cereal-legume intercropping or their combination) could be increased crop income, reduced cost of production and reduction of the risk of crop failure.

\subsection{CONCLUSION}

Climate-induced shocks are common occurrences in developing countries with negative consequences on the welfare and adaptive capacity of rural households. Conservation agriculture (CA) is one of the climate smart agricultural practices receiving increasing attention in SSA as a panacea to the problems associated with conventional agriculture. In an environment characterized by repeated exposure to exogenous shocks and poor soils, CA could be an effective strategy for reducing the risk 
of crop failure associated with climatic factors, improving soil fertility and increasing household welfare. Using recent panel data from Ethiopia and historical weather data, this chapter assesses the impact of CA on household poverty. A multinomial endogenous switching regression model in a panel data framework is used to control for potential selection bias and endogeneity of the choice to use CA.

This chapter provides up-to-date evidence on the drivers of CA use in Ethiopia and the potential incentives for its wider scale adoption. We find evidence that the use of CA in Ethiopia is generally low, uneven and unstable. Surprisingly, the use of a combination of CA practices is rare. Among the strongest determinants of CA choice are climatic factors (rainfall and temperature), soil nutrient constraints, and the enabling environment (such as proximity to markets and extension service). The study provides evidence that a shift away from conventional farming to the increased use of CA can potentially reduce the incidence and depth of rural poverty. Minimum tillage, the most prevalent component of CA has an attractive welfare benefit when used either alone or in combination with cereal-legume intercropping. However, our study finds that crop residue retention and its combined use with minimum tillage is not an attractive CA option for reducing rural poverty. This latter finding may explain why there is low uptake of some of the CA practices in Ethiopia in particular and in SSA at large. Disaggregating the results by rainfall and wealth endowments, we find that minimum tillage and its combined use with cereal-legume intercropping have poverty-reducing benefits in areas experiencing rainfall stress and for households in the lowest quartile of land holding distribution. This is an indication that CA insulates households from welfare risk in less-favored areas prone to climate shocks and for resource poor households. Crop residue retention and conservation tillage increase the probability of being poor, particularly for relatively rich households. The results also show that CA practices that reduce rural poverty are those that increase crop income, reduce the cost of production and mitigate the risk of crop failure. Overall, combined use of minimum tillage and cereal-legume intercropping is the most attractive agronomic practices that could be adopted by farmers as an ex-ante strategy to improve household welfare and reduce exposure to production risks.

While the study provides evidence that can be used to promote the wider scale adoption of CA, the policy question is how to make CA work for the poor. Looking at the effects of CA across different subgroups of farmers, we separate out farm households and specific CA practices that should be targeted by policy interventions. Our findings suggest the need to target promotion of CA practices that generate higher poverty reduction benefits than a rigid recommendation. From a policy perspective, alleviating the barriers to the adoption of CA requires improving access to knowledge and information about CA. Since the agricultural extension system is the common channel through which technologies such as CA reach the wider community, there is a need for building the capacity of CA implementing agencies, mainly the extension services. Moreover, there is a need for creating knowledge platforms where farmers 
could learn about the benefits of CA that are appropriate to their local conditions. If climate-smart practices such as CA are to work for the poor, development and climate finance programs need to shift their focus towards improving the incentives for resource-poor smallholder farmers to invest in CA practices that hold the potential for improving farm productivity, resilience and reduce rural poverty.

Although the findings in this chapter are informative and stimulate further studies, lack of data has been a constraint to increasing the rigor of the study. This stems from the fact that the LSMS-ISA is a multi-purpose survey and finding detail information on CA is difficult. The other caveat of the study primarily emanates from a limitation on the way CA use is measured. In our study, CA is an indicator variable that differentiates whether a household practices any of the three CA practices (minimum tillage, crop residue retention, or cereal-legume intercropping) or a mix of them. However, this measure might capture only partial CA use and does not measure the intensity of CA use. The analysis presented in this paper is based on short panel which does not allow investigating the variation in CA use and its welfare impact in detail. With this caveat in mind, further research using detailed panel data is suggested to provide better evidence on the topic and to improve our understanding of the viability of $\mathrm{CA}$ and its welfare impact. In semi-subsistence agricultural production system where farm households are both producer and consumer of their produce, improved agricultural practices such as CA would have both direct and indirect effects. In particular, CA can have effects that transcend the individual (private) decision maker. While we attempt to explore the direct effect of CA on poverty, future research is needed to capture its indirect (and societal) effects to provide a better picture of the aggregate or net effects. 
Abdulai, A. N. (2016). Impact of conservation agriculture technology on household welfare in Zambia. Agricultural Economics (United Kingdom), 47(6):729-741.

Abro, Z. A., Alemu, B. A., and Hanjra, M. A. (2014). Policies for agricultural productivity growth and poverty reduction in rural Ethiopia. World development, 59:461-474.

Andersson, J. A. and D'Souza, S. (2014). From adoption claims to understanding farmers and contexts: A literature review of Conservation Agriculture (CA) adoption among smallholder farmers in southern Africa. Agriculture, Ecosystems and Environment, 187(June):116-132.

Arslan, A., Belotti, F., and Lipper, L. (2017). Smallholder productivity and weather shocks: Adoption and impact of widely promoted agricultural practices in Tanzania. Food Policy, 69:68-81.

Arslan, A., McCarthy, N., Lipper, L., Asfaw, S., and Cattaneo, A. (2014). Adoption and intensity of adoption of conservation farming practices in Zambia. Agriculture, Ecosystems and Environment, 187:72-86.

Arslan, A., Mccarthy, N., Lipper, L., Asfaw, S., Cattaneo, A., and Kokwe, M. (2015). Climate Smart Agriculture? Assessing the Adaptation Implications in Zambia. Journal of Agricultural Economics, 66(3):753-780.

Asfaw, S., Di Battista, F., and Lipper, L. (2016a). Agricultural technology adoption under climate change in the Sahel: Micro-evidence from Niger. Journal of African Economies, 25(5):637-669.

Asfaw, S., McCarthy, N., Lipper, L., Arslan, A., and Cattaneo, A. (2016b). What determines farmers' adaptive capacity? Empirical evidence from Malawi. Food Security, $8(3): 643-664$.

Bachewe, F. N., Berhane, G., Minten, B., and Taffesse, A. S. (2017). Agricultural Transformation in Africa? Assessing the Evidence in Ethiopia. World Development, 105:286-298.

Barrett, C. B., Christiaensen, L., Sheahan, M., and Shimeles, A. (2017). On the structural transformation of rural Africa. Journal of African Economies, 26(suppl_1):i11-i35.

Baudron, F., Jaleta, M., Okitoi, O., and Tegegn, A. (2014). Conservation agriculture in African mixed crop-livestock systems: Expanding the niche. Agriculture, Ecosystems and Environment, 187:171-182. 
Bezu, S., Kassie, G. T., Shiferaw, B., and Ricker-Gilbert, J. (2014). Impact of improved maize adoption on welfare of farm households in Malawi: A panel data analysis. World Development, 59:120-131.

Bourguignon, F., Fournier, M., and Gurgand, M. (2007). Selection bias corrections based on the multinomial logit model: Monte carlo comparisons. Journal of Economic Surveys, 21(1):174-205.

Bradshaw, B., Dolan, H., and Smit, B. (2004). Farm-level adaptation to climatic variability and change: Crop diversification in the Canadian prairies. Climatic Change, 67(1):119-141.

Cline, W. R. (2008). Global warming and agriculture. Finance and Development, 45(1):23.

de Janvry, A., Fafchamps, M., and Sadoulet, E. (1991). Peasant Household Behaviour with Missing Markets: Some Paradoxes Explained. Economic Journal, 101:1400-1417.

Dercon, S. (2004). Growth and shocks: Evidence from rural Ethiopia. Journal of Development Economics, 74(2):309-329.

Dercon, S. and Christiaensen, L. (2011). Consumption risk, technology adoption and poverty traps: Evidence from Ethiopia. Journal of Development Economics, 96(2):159173 .

Dercon, S., Gilligan, D. O., Hoddinott, J., and Woldehanna, T. (2009). The impact of agricultural extension and roads on poverty and consumption growth in fifteen ethiopian villages. American Journal of Agricultural Economics, 91(4):1007-1021.

Dercon, S., Hoddinott, J., and Woldehanna, T. (2005). Shocks and consumption in 15 Ethiopian villages, 1999-2004. Journal of African Economies, 14(4):559-585.

Di Falco, S. and Chavas, J.-P. (2008). Rainfall shocks, resilience, and the effects of crop biodiversity on agroecosystem productivity. Land Economics, 84(1):83-96.

Di Falco, S. and Veronesi, M. (2013). How can African agriculture adapt to climate change? A counterfactual analysis from Ethiopia. Land Economics, 89(4):743-766.

Di Falco, S., Veronesi, M., and Yesuf, M. (2011). Does Adaptation to Climate Change Provide Food Security? A Micro-Perspective from Ethiopia. American Journal of Agricultural Economics, 93(3):829-846.

Dzanku, F. M., Jirström, M., and Marstorp, H. (2015). Yield Gap-Based Poverty Gaps in Rural Sub-Saharan Africa. World Development, 67:336-362.

Ehrlich, I. and Becker, G. S. (1972). Market insurance, self-insurance, and selfprotection. Journal of Political Economy, 80(4):623-648. 
El-Shater, T., Yigezu, Y. A., Mugera, A., Piggin, C., Haddad, A., Khalil, Y., Loss, S., and Aw-Hassan, A. (2016). Does Zero Tillage Improve the Livelihoods of Smallholder Cropping Farmers? Journal of Agricultural Economics, 67(1):154-172.

Emerick, K., de Janvry, A., Sadoulet, E., and Dar, M. H. (2016). Technological innovations, downside risk, and the modernization of agriculture. American Economic Review, 106(6):1537-1561.

FAO (2010). Climate-smart' agriculture: Policies, practices and financing for food security, adaptation and mitigation. food and agriculture organization of the united nations, rome. Technical report, Food and Agriculture Organization of the United Nations, Rome.

FAO (2013). Climate-Smart Agriculture Sourcebook. Food and Agriculture Organization of the United Nations.

Farris, J., Larochelle, C., Alwang, J., Norton, G. W., and King, C. (2017). Poverty analysis using small area estimation: an application to conservation agriculture in Uganda. Agricultural Economics, 48(6):671-681.

Foster, J., Greer, J., and Thorbecke, E. (1984). A class of decomposable poverty measures. Econometrica, pages 761-766.

Funk, C., Peterson, P., Landsfeld, M., Pedreros, D., Verdin, J., Shukla, S., Husak, G., Rowland, J., Harrison, L., Hoell, A., and Michaelsen, J. (2015). The climate hazards infrared precipitation with stations-a new environmental record for monitoring extremes. Scientific data, 2:150066.

Garnett, T., Appleby, M., Balmford, A., Bateman, I., Benton, T., Bloomer, P., Burlingame, B., Dawkins, M., Dolan, L., Fraser, D., et al. (2013). Sustainable intensification in agriculture: premises and policies. Science, 341(6141):33-34.

Giller, K. E., Corbeels, M., Nyamangara, J., Triomphe, B., Affholder, F., Scopel, E., and Tittonell, P. (2011). A research agenda to explore the role of conservation agriculture in African smallholder farming systems. Field Crops Research, 124(3):468-472.

Giller, K. E., Witter, E., Corbeels, M., and Tittonell, P. (2009). Conservation agriculture and smallholder farming in Africa: The heretics' view. Field Crops Research, $114(1): 23-34$.

Godfray, H. C. J. and Garnett, T. (2014). Food security and sustainable intensification. Philosophical Transactions of the Royal Society of London. Series B, Biological sciences, 369(1639):20120273.

Grabowski, P. P., Kerr, J. M., Haggblade, S., and Kabwe, S. (2016). Determinants of adoption and disadoption of minimum tillage by cotton farmers in eastern Zambia. Agriculture, Ecosystems and Environment, 231:54-67. 
Bibliography

Hanley, N., Shogren, J. F., and White, B. (2007). Environmental Economics in Theory and Practice. Number 333.7 H241. Palgrave Macmillan.

Hansen, J., Hellin, J., Rosenstock, T., Fisher, E., Cairns, J., Stirling, C., Lamanna, C., van Etten, J., Rose, A., and Campbell, B. (2018). Climate risk management and rural poverty reduction. Agricultural Systems.

Hobbs, P., Sayre, K., and Gupta, R. (2008). The role of conservation agriculture in sustainable agriculture. Philosophical Transactions of the Royal Society B: Biological Sciences, 363(1491):543-555.

Hobbs, P. R. (2007). Conservation agriculture: what is it and why is it important for future sustainable food production? Journal of Agricultural Science, 145(2):127.

IPCC (2014). Climate Change 2014-Impacts, Adaptation and Vulnerability: Regional Aspects (Intergovernmental Panel on Climate Change, 2014). Cambridge University Press.

Ito, M., Matsumoto, T., and Quinones, M. A. (2007). Conservation tillage practice in sub-Saharan Africa: The experience of Sasakawa Global 2000. Crop Protection, 26(3):417-423.

Jaleta, M., Kassie, M., and Erenstein, O. (2015). Determinants of maize stover utilization as feed, fuel and soil amendment in mixed crop-livestock systems, Ethiopia. Agricultural Systems, 134:17-23.

Jaleta, M., Kassie, M., Tesfaye, K., Teklewold, T., Jena, P. R., Marenya, P., and Erenstein, O. (2016). Resource saving and productivity enhancing impacts of crop management innovation packages in Ethiopia. Agricultural Economics, 47(5):513-522.

Jayne, T. S., Sitko, N. J., Mason, N. M., and Skole, D. (2018). Input subsidy programs and climate smart agriculture: Current realities and future potential. In Climate Smart Agriculture, pages 251-273. Springer.

Jirata, M., Grey, S., and Kilawe, E. (2016). Ethiopia Climate-Smart Agriculture Scoping Study. Technical report, Food and Agriculture Organization of the United Nations (FAO), Addis Ababa.

Juma, C., Tabo, R., Wilson, K., and Conway, G. (2013). Innovation for Sustainable Intensification in Africa. Montpellier Panel Briefing, Agriculture for Impact, London.

Kassam, A., Friedrich, T., Shaxson, F., and Pretty, J. (2009). The spread of conservation agriculture: justification, sustainability and uptake. International Journal of Agricultural Sustainability, 7(4):292-320.

Kassie, M., Marenya, P., Tessema, Y., Jaleta, M., Zeng, D., Erenstein, O., and Rahut, D. (2017). Measuring farm and market level economic impacts of improved maize production technologies in Ethiopia: Evidence from panel data. Journal of Agricultural Economics, 69:76-95. 
Kassie, M., Teklewold, H., Marenya, P., Jaleta, M., and Erenstein, O. (2015). Production Risks and Food Security under Alternative Technology Choices in Malawi: Application of a Multinomial Endogenous Switching Regression. Journal of Agricultural Economics, 66(3):640-659.

Khonje, M. G., Manda, J., Mkandawire, P., Tufa, A. H., and Alene, A. D. (2018). Adoption and welfare impacts of multiple agricultural technologies: evidence from eastern zambia. Agricultural Economics, 49(5):599-609.

Knowler, D. and Bradshaw, B. (2007). Farmers' adoption of conservation agriculture: A review and synthesis of recent research. Food Policy, 32(1):25-48.

Kpadonou, R. A. B., Owiyo, T., Barbier, B., Denton, F., Rutabingwa, F., and Kiema, A. (2017). Advancing climate-smart-agriculture in developing drylands: Joint analysis of the adoption of multiple on-farm soil and water conservation technologies in West African Sahel. Land Use Policy, 61:196-207.

Lalani, B., Dorward, P., Holloway, G., and Wauters, E. (2016). Smallholder farmers' motivations for using Conservation Agriculture and the roles of yield, labour and soil fertility in decision making. Agricultural Systems, 146:80-90.

Lipper, L., Thornton, P., Campbell, B. M., Baedeker, T., Braimoh, A., Bwalya, M., Caron, P., Cattaneo, A., Garrity, D., Henry, K., Hottle, R., Jackson, L., Jarvis, A., Kossam, F., Mann, W., McCarthy, N., Meybeck, A., Neufeldt, H., Remington, T., Sen, P. T., Sessa, R., Shula, R., Tibu, A., and Torquebiau, E. F. (2014). Climate-smart agriculture for food security. Nature Climate Change, 4(12):1068-1072.

Lobell, D. B., Burke, M. B., Tebaldi, C., Mastrandrea, M. D., Falcon, W. P., and Naylor, R. L. (2008). Prioritizing climate change adaptation needs for food security in 2030. Science, 319(5863):607-610.

Malikov, E. and Kumbhakar, S. C. (2014). A generalized panel data switching regression model. Economics Letters, 124(3):353-357.

Marenya, P., Kassie, M., Jaleta, M., Rahut, D., and Erenstein, O. (2015). Adoption of Conservation Agriculture Under Alternative Agricultural Policy and Market Access Indicators: Evidence From Eastern and Southern Africa. In International Conference of Agricultural Economists, Milan, Italy.

Marenya, P. P. and Barrett, C. B. (2009). State-conditional fertilizer yield response on Western Kenyan Farms. American Journal of Agricultural Economics, 91(4):991-1006.

Mason, N. M. and Smale, M. (2013). Impacts of subsidized hybrid seed on indicators of economic well-being among smallholder maize growers in zambia. Agricultural Economics, 44(6):659-670.

McFadden, D. (1973). Conditional logit analysis of qualitative choice behavior. 
Bibliography

Mendelsohn, R., Nordhaus, W. D., and Shaw, D. (1994). The impact of global warming on agriculture: a ricardian analysis. American Economic Review, 84(4):753-771.

Michler, J., Baylis, K., Arends-Kuenning, M., and Mazvimavi, K. (2018). Conservation agriculture and climate resilience. Journal of Environmental Economics and Management, 93:148-169.

Michler, J. D. and Josephson, A. L. (2017). To Specialize or Diversify: Agricultural Diversity and Poverty Dynamics in Ethiopia. World Development, 89:214-226.

Mundlak, Y. (1978). On the Pooling of Times Series and Cross Section Data. Econometrica, 45(1):69-85.

Mundlak, Y. (2001). Production and supply. Handbook of agricultural economics, 1:3-85.

Mutenje, M., Kankwamba, H., Mangisonib, J., and Kassie, M. (2016). Agricultural innovations and food security in Malawi: Gender dynamics, institutions and market implications. Technological Forecasting and Social Change, 103:240-248.

Neufeldt, H., Kristjanson, P., Thorlakson, T., Gassner, A., Norton-Griffiths, M., Place, F., and Langford, K. (2011). Making climate-smart agriculture work for the poor. World Agroforestry Center Policy Brief No.12, pages 1-6.

Ngoma, H. (2018). Does minimum tillage improve the livelihood outcomes of smallholder farmers in Zambia? Food Security, 10(2):381-396.

Ngoma, H., Mulenga, B. P., and Jayne, T. S. (2016). Minimum tillage uptake and uptake intensity by smallholder farmers in Zambia. African Journal of Agricultural and Resource Economics, 11(4):249-262.

Pannell, D. J., Llewellyn, R. S., and Corbeels, M. (2014). The farm-level economics of conservation agriculture for resource-poor farmers. Agriculture, Ecosystems and Environment, 187:52-64.

Pittelkow, C. M., Liang, X., Linquist, B. a., van Groenigen, K. J., Lee, J., Lundy, M. E., van Gestel, N., Six, J., Venterea, R. T., and van Kessel, C. (2015). Productivity limits and potentials of the principles of conservation agriculture. Nature, 517(7534):365367 .

Pretty, J., Toulmin, C., and Williams, S. (2011). Sustainable intensification in African agriculture. International Journal of Agricultural Sustainability, 9(1):5-24.

Rodriguez, D., de Voil, P., Rufino, M. C., Odendo, M., and van Wijk, M. T. (2017). To mulch or to munch? big modelling of big data. Agricultural Systems, 153:32-42.

Rubin, D. B. (1978). Bayesian inference for causal effects: The role of randomization. The Annals of Statistics, pages 34-58. 
Sime, G., Aune, J. B., and Mohammed, H. (2015). Agronomic and economic response of tillage and water conservation management in maize, central rift valley in Ethiopia. Soil and Tillage Research, 148:20-30.

Singh, I., Squire, L., and Strauss, J. (1986). Agricultural Household Models: Extensions, Applications and Policy. Johns Hopkins University Press, U.S.A.

Steward, P. R., Dougill, A. J., Thierfelder, C., Pittelkow, C. M., Stringer, L. C., Kudzala, M., and Shackelford, G. E. (2018). The adaptive capacity of maize-based conservation agriculture systems to climate stress in tropical and subtropical environments: A meta-regression of yields. Agriculture, Ecosystems E Environment, 251:194-202.

Suri, T. (2011). Selection and comparative advantage in technology adoption. Econometrica, 79(1):159-209.

Tambo, J. A. and Mockshell, J. (2018). Differential Impacts of Conservation Agriculture Technology Options on Household Income in Sub-Saharan Africa. Ecological Economics, 151:95-105.

Tanaka, T., Camerer, C. F., and Nguyen, Q. (2010). Risk and Time Preferences: Linking Experimental and Household Survey Data from Vietnam. American Economic Review, 100(1):557-71.

Teklewold, H., Kassie, M., Shiferaw, B., and Köhlin, G. (2013). Cropping system diversification, conservation tillage and modern seed adoption in Ethiopia: Impacts on household income, agrochemical use and demand for labor. Ecological Economics, 93:85-93.

Teklewold, H. and Mekonnen, A. (2017). The tilling of land in a changing climate : Empirical evidence from the Nile Basin of Ethiopia. Land Use Policy, 67(June):449459 .

Tessema, Y., Asafu-Adjaye, J., Rodriguez, D., Mallawaarachchi, T., and Shiferaw, B. (2015). A bio-economic analysis of the benefits of conservation agriculture: The case of smallholder farmers in Adami Tulu district, Ethiopia. Ecological Economics, 120:164-174.

Tessema, Y. M., Asafu-Adjaye, J., Kassie, M., and Mallawaarachchi, T. (2016). Do neighbours matter in technology adoption? The case of conservation tillage in northwest Ethiopia. African Journal of Agriculture and Resource Economics, 11(3):211-225.

Thierfelder, C., Chivenge, P., Mupangwa, W., Rosenstock, T. S., Lamanna, C., and Eyre, J. X. (2017). How climate-smart is conservation agriculture (CA)?-its potential to deliver on adaptation, mitigation and productivity on smallholder farms in southern Africa. Food Security, 9(3):537-560. 
Bibliography

Thierfelder, C., Mwila, M., and Rusinamhodzi, L. (2013). Conservation agriculture in eastern and southern provinces of Zambia: Long-term effects on soil quality and maize productivity. Soil and Tillage Research, 126:246-258.

Tittonell, P. and Giller, K. E. (2013). When yield gaps are poverty traps: The paradigm of ecological intensification in African smallholder agriculture. Field Crops Research, 143:76-90.

Tsegaye, W., Aredo, D., Rovere, L., Mwangi, W., Mwabu, G., and Tesfahun, G. (2008). Does partial adoption of conservation agriculture affect crop yields and labour use? evidence from two districts in Ethiopia. Technical report, Nippon IA Research Report.

van Ittersum, M. K., Van Bussel, L. G., Wolf, J., Grassini, P., Van Wart, J., Guilpart, N., Claessens, L., de Groot, H., Wiebe, K., Mason-D'Croz, D., Boogaard, H., Cassman, H., van Oort Marloes P., P. A. J., and Kenneth G., v. L. (2016). Can Sub-Saharan Africa feed itself? Proceedings of the National Academy of Sciences, 113(52):1496414969.

Verkaart, S., Munyua, B. G., Mausch, K., and Michler, J. D. (2017). Welfare impacts of improved chickpea adoption: A pathway for rural development in Ethiopia? Food Policy, 66:50-61.

Ward, P. S. and Shively, G. E. (2015). Migration and land rental as responses to income shocks in rural china. Pacific Economic Review, 20(4):511-543.

Wheeler, T. and Von Braun, J. (2013). Climate change impacts on global food security. Science, 341(6145):508-513.

Wooldridge, J. M. (2002). Econometric Analysis of Cross Section and Panel Data. Cambridge, MA: The MIT Press, London.

Wu, J. and Babcock, B. A. (1998). The choice of tillage, rotation, and soil testing practices: Economic and environmental implications. American Journal of Agricultural Economics, 80(3):494-511.

Zeng, D., Alwang, J., Norton, G. W., Shiferaw, B., Jaleta, M., and Yirga, C. (2015). Ex post impacts of improved maize varieties on poverty in rural Ethiopia. Agricultural Economics, 46(4):515-526. 


\section{APPENDIX}

Table A.1: Proportions of households practicing CA (\%)

\begin{tabular}{lccc}
\hline \hline CA technology set & 2013 & 2015 & Pooled \\
\hline Minimum tillage & 0.595 & $0.432^{* * *}$ & 0.514 \\
& $(0.491)$ & $(0.495)$ & $(0.500)$ \\
Crop residue or mulch & 0.035 & $0.089^{* * *}$ & 0.062 \\
& $(0.184)$ & $(0.285)$ & $(0.241)$ \\
Cereal-legume intercropping & 0.107 & 0.097 & 0.102 \\
& $(0.310)$ & $(0.296)$ & $(0.303)$ \\
Minimum tillage \& crop residue & 0.023 & $0.061^{* * *}$ & 0.042 \\
& $(0.150)$ & $(0.240)$ & $(0.201)$ \\
Minimum tillage \& cereal-legume & 0.066 & $0.054^{* *}$ & 0.060 \\
Crop residue \& cereal-legume & $(0.248)$ & $(0.225)$ & $(0.237)$ \\
& 0.004 & $0.010^{* * *}$ & 0.007 \\
Min. tillage, crop residue \& cereal-legume & 0.002 & $0.007^{* * *}$ & 0.004 \\
& $(0.044)$ & $(0.083)$ & $(0.066)$ \\
\hline \hline
\end{tabular}

Note: Standard deviations in parentheses; ${ }^{*} p<0.10$, ** $p<0.05$, *** $p<0.01$. Proportion (mean) difference tests are based on 2013 as a reference. The CA sets are not mutually exclusive. The sample size is 3075 and 3027 for 2013 and 2015 respectively. 
Table A.2: Transitions in CA use over the sample periods 2013 and 2015 (\%)

\begin{tabular}{lcccc}
\hline \hline CA practices & Stayers & Leavers & Joiners & Nonusers \\
\hline Minimum tillage & 32.1 & 27.0 & 11.8 & 29.1 \\
Crop residue retention & 0.3 & 2.8 & 8.8 & 88.1 \\
Cereal-legume intercrop & 3.3 & 6.6 & 5.2 & 84.9 \\
Min. tillage \& crop residue & 0.1 & 1.7 & 6.3 & 91.9 \\
Min. tillage \& cereal-legume intercropping & 1.8 & 5.0 & 3.4 & 89.9 \\
Crop residue \& cereal-legume intercropping & 0.0 & 0.4 & 1.0 & 98.6 \\
Comprehensive CA package (all 3 practices) & 0.0 & 0.2 & 0.7 & 99.1 \\
\hline \hline
\end{tabular}

Note: Results are based on a balanced sample of 5630 households ( 2815 in each period).

Table A.3: Household characteristics by CA sets

\begin{tabular}{|c|c|c|c|c|c|c|c|}
\hline & $\mathrm{T}_{0} R_{0} C_{0}$ & $\mathrm{~T}_{1} R_{0} \mathrm{C}_{0}$ & $\mathrm{~T}_{0} R_{1} C_{0}$ & $\mathrm{~T}_{0} R_{0} C_{1}$ & $\mathrm{~T}_{1} R_{1} C_{0}$ & $\mathrm{~T}_{1} R_{0} C_{1}$ & Pooled \\
\hline Household size (adult equivalent) & $\begin{array}{c}3.949 \\
(1.954)\end{array}$ & $\begin{array}{c}4.245 \\
(1.839)\end{array}$ & $\begin{array}{c}4.805 \\
(2.180)\end{array}$ & $\begin{array}{c}4.675 \\
(1.925)\end{array}$ & $\begin{array}{c}4.255 \\
(1.924)\end{array}$ & $\begin{array}{c}4.368 \\
(1.876)\end{array}$ & $\begin{array}{c}4.144 \\
(1.914)\end{array}$ \\
\hline Male headed & $\begin{array}{c}0.712 \\
(0.453)\end{array}$ & $\begin{array}{c}0.782 \\
(0.413)\end{array}$ & $\begin{array}{c}0.788 \\
(0.410)\end{array}$ & $\begin{array}{c}0.833 \\
(0.374)\end{array}$ & $\begin{array}{c}0.800 \\
(0.401)\end{array}$ & $\begin{array}{c}0.802 \\
(0.399)\end{array}$ & $\begin{array}{c}0.755 \\
(0.430)\end{array}$ \\
\hline Age of head (years) & $\begin{array}{c}47.92 \\
(15.76)\end{array}$ & $\begin{array}{c}46.64 \\
(14.65)\end{array}$ & $\begin{array}{c}47.63 \\
(14.47)\end{array}$ & $\begin{array}{c}48.68 \\
\left(14.5^{8}\right)\end{array}$ & $\begin{array}{c}48.24 \\
(15.08)\end{array}$ & $\begin{array}{c}46.35 \\
(14.78)\end{array}$ & $\begin{array}{c}47.33 \\
(15.18)\end{array}$ \\
\hline Head education ( $1=$ primary or less) & $\begin{array}{c}0.248 \\
(0.432)\end{array}$ & $\begin{array}{c}0.291 \\
(0.454)\end{array}$ & $\begin{array}{c}0.346 \\
(0.478)\end{array}$ & $\begin{array}{c}0.228 \\
(0.421)\end{array}$ & $\begin{array}{c}0.252 \\
(0.435)\end{array}$ & $\begin{array}{c}0.257 \\
(0.438)\end{array}$ & $\begin{array}{c}0.268 \\
(0.443)\end{array}$ \\
\hline Agricultural asset wealth (index) & $\begin{array}{c}0.198 \\
(1.216)\end{array}$ & $\begin{array}{c}0.612 \\
(1.027)\end{array}$ & $\begin{array}{c}0.445 \\
(1.196)\end{array}$ & $\begin{array}{c}0.699 \\
(0.982)\end{array}$ & $\begin{array}{c}0.688 \\
(1.034)\end{array}$ & $\begin{array}{c}0.573 \\
(1.036)\end{array}$ & $\begin{array}{c}0.430 \\
(1.135)\end{array}$ \\
\hline Livestock holdings (TLU) & $\begin{array}{c}3.835 \\
(5.404)\end{array}$ & $\begin{array}{c}3.803 \\
(4.759)\end{array}$ & $\begin{array}{c}3.654 \\
(3.648)\end{array}$ & $\begin{array}{c}4.614 \\
(7.963)\end{array}$ & $\begin{array}{c}3.812 \\
(4.717)\end{array}$ & $\begin{array}{c}2.919 \\
(3.024)\end{array}$ & $\begin{array}{c}3.790 \\
(5.085)\end{array}$ \\
\hline Land size (hectares) & $\begin{array}{c}1.281 \\
(4.334)\end{array}$ & $\begin{array}{c}1.740 \\
(8.780)\end{array}$ & $\begin{array}{c}1.618 \\
(2.800)\end{array}$ & $\begin{array}{c}1.702 \\
(2.231)\end{array}$ & $\begin{array}{c}1.502 \\
(3.152)\end{array}$ & $\begin{array}{c}1.541 \\
(4.869)\end{array}$ & $\begin{array}{l}1.515 \\
(6.529)\end{array}$ \\
\hline Credit access $(1=$ Yes) & $\begin{array}{c}0.165 \\
(0.371)\end{array}$ & $\begin{array}{c}0.191 \\
(0.393)\end{array}$ & $\begin{array}{c}0.308 \\
(0.464)\end{array}$ & $\begin{array}{c}0.194 \\
(0.397)\end{array}$ & $\begin{array}{c}0.187 \\
(0.391)\end{array}$ & $\begin{array}{c}0.169 \\
(0.375)\end{array}$ & $\begin{array}{c}0.180 \\
(0.384)\end{array}$ \\
\hline Distance to road $(\mathrm{Km})$ & $\begin{array}{c}16.99 \\
(27.20)\end{array}$ & $\begin{array}{c}16.73 \\
(18.86)\end{array}$ & $\begin{array}{c}13.75 \\
(11.86)\end{array}$ & $\begin{array}{c}14.86 \\
(13.22)\end{array}$ & $\begin{array}{c}15.13 \\
(14.50)\end{array}$ & $\begin{array}{c}19.45 \\
(15.94)\end{array}$ & $\begin{array}{c}16.83 \\
(22.47)\end{array}$ \\
\hline Distance to market $(\mathrm{Km})$ & $\begin{array}{c}62.22 \\
(48.74)\end{array}$ & $\begin{array}{c}66.15 \\
(48.41)\end{array}$ & $\begin{array}{c}70.05 \\
(46.65)\end{array}$ & $\begin{array}{c}81.55 \\
(69.45)\end{array}$ & $\begin{array}{c}69.50 \\
(45.67)\end{array}$ & $\begin{array}{c}88.71 \\
(67.69)\end{array}$ & $\begin{array}{c}66.33 \\
(50.83)\end{array}$ \\
\hline Inorganic fertilizer $(1=Y e s)$ & $\begin{array}{c}0.444 \\
(0.497)\end{array}$ & $\begin{array}{c}0.467 \\
(0.499)\end{array}$ & $\begin{array}{c}0.538 \\
(0.501)\end{array}$ & $\begin{array}{c}0.506 \\
(0.501)\end{array}$ & $\begin{array}{c}0.509 \\
(0.501)\end{array}$ & $\begin{array}{c}0.438 \\
(0.497)\end{array}$ & $\begin{array}{c}0.459 \\
(0.498)\end{array}$ \\
\hline Organic fertilizer ( $1=$ Yes) & $\begin{array}{c}0.480 \\
(0.500)\end{array}$ & $\begin{array}{c}0.608 \\
(0.488)\end{array}$ & $\begin{array}{c}0.769 \\
(0.423)\end{array}$ & $\begin{array}{c}0.672 \\
(0.471)\end{array}$ & $\begin{array}{c}0.5^{8} 7 \\
(0.493)\end{array}$ & $\begin{array}{c}0.648 \\
(0.478)\end{array}$ & $\begin{array}{c}0.558 \\
(0.497)\end{array}$ \\
\hline Advice on crop production & $\begin{array}{c}0.629 \\
(0.483)\end{array}$ & $\begin{array}{c}0.689 \\
(0.463)\end{array}$ & $\begin{array}{c}0.760 \\
(0.429)\end{array}$ & $\begin{array}{c}0.678 \\
(0.469)\end{array}$ & $\begin{array}{c}0.743 \\
(0.438)\end{array}$ & $\begin{array}{c}0.754 \\
(0.431)\end{array}$ & $\begin{array}{c}0.669 \\
(0.471)\end{array}$ \\
\hline Advice on NRM & $\begin{array}{c}0.643 \\
(0.479)\end{array}$ & $\begin{array}{c}0.715 \\
(0.452)\end{array}$ & $\begin{array}{c}0.846 \\
(0.363)\end{array}$ & $\begin{array}{c}0.728 \\
(0.446)\end{array}$ & $\begin{array}{c}0.700 \\
(0.459)\end{array}$ & $\begin{array}{c}0.825 \\
(0.380)\end{array}$ & $\begin{array}{c}0.691 \\
(0.462)\end{array}$ \\
\hline No soil nutrient constraint & $\begin{array}{c}0.728 \\
(0.445) \\
\end{array}$ & $\begin{array}{c}0.566 \\
(0.496) \\
\end{array}$ & $\begin{array}{c}0.740 \\
(0.441)\end{array}$ & $\begin{array}{c}0.728 \\
(0.446) \\
\end{array}$ & $\begin{array}{c}0.674 \\
(0.470) \\
\end{array}$ & $\begin{array}{c}0.615 \\
(0.487) \\
\end{array}$ & $\begin{array}{c}0.652 \\
(0.476) \\
\end{array}$ \\
\hline
\end{tabular}


Table A.3 ...continued

\begin{tabular}{lccccccc}
\hline \hline & $\mathrm{T}_{0} R_{0} C_{0}$ & $\mathrm{~T}_{1} R_{0} C_{0}$ & $\mathrm{~T}_{0} R_{1} C_{0}$ & $\mathrm{~T}_{0} R_{0} C_{1}$ & $\mathrm{~T}_{1} R_{1} C_{0}$ & $\mathrm{~T}_{1} R_{0} C_{1}$ & Pooled \\
\hline Good quality soil plots & 1.048 & 1.286 & 1.067 & 1.311 & 0.965 & 1.370 & 1.171 \\
& $(1.581)$ & $(1.681)$ & $(1.503)$ & $(1.565)$ & $(1.450)$ & $(1.602)$ & $(1.623)$ \\
Poor soil quality plots & 0.559 & 0.766 & 0.615 & 1.006 & 0.743 & 0.867 & 0.684 \\
& $(1.163)$ & $(1.573)$ & $(1.225)$ & $(1.388)$ & $(1.354)$ & $(1.440)$ & $(1.384)$ \\
Price rise of farm inputs & 0.129 & 0.0991 & 0.212 & 0.178 & 0.148 & 0.0769 & 0.117 \\
& $(0.335)$ & $(0.299)$ & $(0.410)$ & $(0.383)$ & $(0.356)$ & $(0.267)$ & $(0.321)$ \\
Mean temperature & 19.38 & 19.52 & 19.08 & 19.65 & 18.98 & 19.85 & 19.45 \\
& $(3.796)$ & $(3.538)$ & $(2.875)$ & $(2.055)$ & $(3.288)$ & $(2.371)$ & $(3.549)$ \\
Rainfall previous year & 733.0 & 930.5 & 806.6 & 708.1 & 857.4 & 817.6 & 825.9 \\
& $(361.7)$ & $(380.4)$ & $(267.7)$ & $(303.8)$ & $(359.2)$ & $(328.5)$ & $(376.7)$ \\
Average historical rainfall & 687.9 & 844.2 & 769.5 & 642.9 & 815.4 & 732.5 & 760.9 \\
& $(342.9)$ & $(348.5)$ & $(274.6)$ & $(267.8)$ & $(325.0)$ & $(316.7)$ & $(348.5)$ \\
Std. dev. of rainfall & 99.55 & 105.0 & 106.7 & 100.6 & 107.1 & 102.4 & 102.4 \\
& $(36.02)$ & $(32.85)$ & $(25.71)$ & $(32.71)$ & $(29.56)$ & $(30.06)$ & $(34.01)$ \\
\hline Observations & 2,664 & 2,543 & 104 & 180 & 230 & 338 & 6,059 \\
\hline \hline
\end{tabular}

Note: $\mathrm{T}, \mathrm{R}$ and $\mathrm{C}$ refer to minimum tillage, crop residue retention and cereal-legume intercropping; The subscripts ' $O$ ' and ' 1 ' denote use and non use, respectively. NRM is Natural Resources Management; Mean coefficients; Std. dev. in parentheses. 
Table A.4: Drivers of CA use: Marginal effects

\begin{tabular}{|c|c|c|c|c|c|}
\hline & $\mathrm{T}_{1} R_{0} C_{0}$ & $\mathrm{~T}_{0} R_{1} C_{0}$ & $\mathrm{~T}_{0} R_{0} \mathrm{C}_{1}$ & $\mathrm{~T}_{1} R_{1} C_{0}$ & $\mathrm{~T}_{1} R_{0} C_{1}$ \\
\hline Household size & $\begin{array}{l}-0.007 \\
(0.011)\end{array}$ & $\begin{array}{c}0.002 \\
(0.003)\end{array}$ & $\begin{array}{l}0.009^{* *} \\
(0.004)\end{array}$ & $\begin{array}{l}-0.004 \\
(0.005)\end{array}$ & $\begin{array}{c}0.002 \\
(0.006)\end{array}$ \\
\hline Male headed & $\begin{array}{c}0.028 \\
(0.065)\end{array}$ & $\begin{array}{c}-0.003 \\
(0.019)\end{array}$ & $\begin{array}{l}-0.029 \\
(0.025)\end{array}$ & $\begin{array}{l}-0.033 \\
(0.026)\end{array}$ & $\begin{array}{l}-0.025 \\
(0.034)\end{array}$ \\
\hline Age of head & $\begin{array}{l}-0.003^{*} \\
(0.002)\end{array}$ & $\begin{array}{c}0.001 \\
(0.001)\end{array}$ & $\begin{array}{c}0.000 \\
(0.001)\end{array}$ & $\begin{array}{l}-0.000 \\
(0.001)\end{array}$ & $\begin{array}{l}-0.000 \\
(0.001)\end{array}$ \\
\hline Head education & $\begin{array}{c}0.016 \\
(0.034)\end{array}$ & $\begin{array}{l}-0.015^{*} \\
(0.009)\end{array}$ & $\begin{array}{c}0.016 \\
(0.013)\end{array}$ & $\begin{array}{c}0.012 \\
(0.014)\end{array}$ & $\begin{array}{c}0.012 \\
(0.016)\end{array}$ \\
\hline Agricultural asset wealth & $\begin{array}{l}-0.006 \\
(0.011)\end{array}$ & $\begin{array}{l}-0.007^{* *} \\
(0.003)\end{array}$ & $\begin{array}{c}0.002 \\
(0.004)\end{array}$ & $\begin{array}{l}0.009^{*} \\
(0.005)\end{array}$ & $\begin{array}{c}0.001 \\
(0.005)\end{array}$ \\
\hline Credit access & $\begin{array}{l}-0.013 \\
(0.026)\end{array}$ & $\begin{array}{l}0.014^{* *} \\
(0.007)\end{array}$ & $\begin{array}{c}0.011 \\
(0.009)\end{array}$ & $\begin{array}{c}0.004 \\
(0.010)\end{array}$ & $\begin{array}{l}-0.005 \\
(0.012)\end{array}$ \\
\hline Livestock holdings (log) & $\begin{array}{c}0.004 \\
(0.006)\end{array}$ & $\begin{array}{c}0.000 \\
(0.002)\end{array}$ & $\begin{array}{c}-0.001 \\
(0.002)\end{array}$ & $\begin{array}{c}0.003 \\
(0.002)\end{array}$ & $\begin{array}{c}0.002 \\
(0.003)\end{array}$ \\
\hline Land size (log) & $\begin{array}{c}0.006 \\
(0.012)\end{array}$ & $\begin{array}{l}0.008^{* *} \\
(0.004)\end{array}$ & $\begin{array}{l}0.008^{*} \\
(0.005)\end{array}$ & $\begin{array}{c}0.001 \\
(0.005)\end{array}$ & $\begin{array}{c}0.006 \\
(0.006)\end{array}$ \\
\hline Advice on crop production & $\begin{array}{c}0.010 \\
(0.028)\end{array}$ & $\begin{array}{l}-0.014^{*} \\
(0.008)\end{array}$ & $\begin{array}{l}-0.000 \\
(0.010)\end{array}$ & $\begin{array}{c}-0.004 \\
(0.012)\end{array}$ & $\begin{array}{l}-0.011 \\
(0.014)\end{array}$ \\
\hline Advice on NRM & $\begin{array}{c}0.004 \\
(0.031)\end{array}$ & $\begin{array}{c}0.027^{* * *} \\
(0.010)\end{array}$ & $\begin{array}{l}-0.011 \\
(0.012)\end{array}$ & $\begin{array}{l}0.021^{*} \\
(0.013)\end{array}$ & $\begin{array}{c}0.002 \\
(0.017)\end{array}$ \\
\hline Distance to road & $\begin{array}{l}-0.000 \\
(0.000)\end{array}$ & $\begin{array}{l}-0.000 \\
(0.000)\end{array}$ & $\begin{array}{c}-0.000^{* *} \\
(0.000)\end{array}$ & $\begin{array}{l}-0.000 \\
(0.000)\end{array}$ & $\begin{array}{l}-0.000 \\
(0.000)\end{array}$ \\
\hline Distance to market & $\begin{array}{c}0.001^{* * *} \\
(0.000)\end{array}$ & $\begin{array}{c}-0.000 \\
(0.000)\end{array}$ & $\begin{array}{c}0.000 \\
(0.000)\end{array}$ & $\begin{array}{c}0.000 \\
(0.000)\end{array}$ & $\begin{array}{c}0.000^{* * *} \\
(0.000)\end{array}$ \\
\hline No soil nutrient constraint & $\begin{array}{c}-0.080^{* * *} \\
(0.014)\end{array}$ & $\begin{array}{l}0.008^{*} \\
(0.005)\end{array}$ & $\begin{array}{l}-0.007 \\
(0.006)\end{array}$ & $\begin{array}{c}0.006 \\
(0.006)\end{array}$ & $\begin{array}{l}-0.001 \\
(0.007)\end{array}$ \\
\hline Good quality soil plots & $\begin{array}{c}0.010 \\
(0.007)\end{array}$ & $\begin{array}{l}-0.004^{*} \\
(0.002)\end{array}$ & $\begin{array}{l}-0.001 \\
(0.002)\end{array}$ & $\begin{array}{c}-0.008^{* * *} \\
(0.003)\end{array}$ & $\begin{array}{c}0.002 \\
(0.003)\end{array}$ \\
\hline Poor soil quality plots & $\begin{array}{l}-0.000 \\
(0.008)\end{array}$ & $\begin{array}{c}0.001 \\
(0.003)\end{array}$ & $\begin{array}{c}0.002 \\
(0.003)\end{array}$ & $\begin{array}{c}0.011^{* * *} \\
(0.004)\end{array}$ & $\begin{array}{l}-0.001 \\
(0.004)\end{array}$ \\
\hline Organic fertilizer & $\begin{array}{c}0.086^{* * *} \\
(0.026)\end{array}$ & $\begin{array}{c}0.006 \\
(0.008)\end{array}$ & $\begin{array}{l}-0.003 \\
(0.009)\end{array}$ & $\begin{array}{c}-0.034^{* * *} \\
(0.011)\end{array}$ & $\begin{array}{c}0.013 \\
(0.012)\end{array}$ \\
\hline Price rise of farm inputs & $\begin{array}{l}-0.042 \\
(0.028)\end{array}$ & $\begin{array}{c}0.011 \\
(0.008)\end{array}$ & $\begin{array}{c}0.015 \\
(0.010)\end{array}$ & $\begin{array}{l}-0.017 \\
(0.011)\end{array}$ & $\begin{array}{l}-0.018 \\
(0.015)\end{array}$ \\
\hline Mean temperature & $\begin{array}{l}0.005^{* *} \\
(0.002)\end{array}$ & $\begin{array}{l}0.001^{*} \\
(0.001)\end{array}$ & $\begin{array}{c}0.004^{* * *} \\
(0.001)\end{array}$ & $\begin{array}{l}-0.001 \\
(0.001)\end{array}$ & $\begin{array}{l}0.005^{* * *} \\
(0.001)\end{array}$ \\
\hline Rainfall previous year & $\begin{array}{c}0.000 \\
(0.000)\end{array}$ & $\begin{array}{l}-0.000 \\
(0.000)\end{array}$ & $\begin{array}{l}-0.000 \\
(0.000)\end{array}$ & $\begin{array}{l}-0.000 \\
(0.000)\end{array}$ & $\begin{array}{l}0.000^{*} \\
(0.000)\end{array}$ \\
\hline
\end{tabular}


Table A.4 ... continued

\begin{tabular}{lccccc}
\hline \hline & $\mathrm{T}_{1} R_{0} C_{0}$ & $\mathrm{~T}_{0} R_{1} C_{0}$ & $\mathrm{~T}_{0} R_{0} C_{1}$ & $\mathrm{~T}_{1} R_{1} C_{0}$ & $\mathrm{~T}_{1} R_{0} C_{1}$ \\
\hline Average rainfall & 0.000 & -0.000 & $-0.000^{* * *}$ & $-0.000^{* * *}$ & -0.000 \\
& $(0.000)$ & $(0.000)$ & $(0.000)$ & $(0.000)$ & $(0.000)$ \\
Std. dev. of rainfall & -0.000 & $0.000^{* *}$ & $0.000^{*}$ & 0.000 & $0.000^{* *}$ \\
& $(0.000)$ & $(0.000)$ & $(0.000)$ & $(0.000)$ & $(0.000)$ \\
Year (=2015/16) & $-0.149^{* * *}$ & $0.014^{* *}$ & -0.004 & $0.031^{* * *}$ & 0.003 \\
& $(0.022)$ & $(0.007)$ & $(0.009)$ & $(0.010)$ & $(0.011)$ \\
Region dummies & Yes & Yes & Yes & Yes & Yes \\
Mundlak variables $\left(\chi^{2}\right)$ & $36.13^{* * *}$ & 13.92 & $27.13^{* *}$ & $61.80^{* * *}$ & $24.68^{*}$ \\
Wald $\chi^{2}$ & $1612.35^{* * *}$ & & & & \\
LR $\chi^{2}$ & $2194.91^{* * *}$ & & & & \\
Pseudo $R^{2}$ & 0.153 & & & & \\
Observations & 6,048 & & & & \\
\hline \hline
\end{tabular}

Note: $\mathrm{T}, \mathrm{R}$ and $\mathrm{C}$ refer to minimum tillage, crop residue retention and cereal-legume intercropping; The subscripts ' $\mathrm{o}$ ' and ' $\mathrm{I}$ ' denote non use and use, respectively.

Robust standard errors in parentheses. ${ }^{*} p<0.10,{ }^{* *} p<0.05,{ }^{* * *} p<0.01$ 
Table A.5: Poverty headcount equation estimates

\begin{tabular}{|c|c|c|c|c|c|c|}
\hline & $\mathrm{T}_{0} R_{0} \mathrm{C}_{0}$ & $\mathrm{~T}_{1} R_{0} \mathrm{C}_{0}$ & $\mathrm{~T}_{0} R_{1} C_{0}$ & $\mathrm{~T}_{0} R_{0} \mathrm{C}_{1}$ & $\mathrm{~T}_{1} R_{1} C_{0}$ & $\mathrm{~T}_{1} R_{0} \mathrm{C}_{1}$ \\
\hline Household size & $\begin{array}{l}0.083^{* * *} \\
(0.016)\end{array}$ & $\begin{array}{c}0.074^{* * *} \\
(0.016)\end{array}$ & $\begin{array}{l}0.244^{*} \\
(0.126)\end{array}$ & $\begin{array}{c}0.053 \\
(0.142)\end{array}$ & $\begin{array}{l}-0.060 \\
(0.064)\end{array}$ & $\begin{array}{c}0.056 \\
(0.059)\end{array}$ \\
\hline Male headed & $\begin{array}{l}-0.008 \\
(0.091)\end{array}$ & $\begin{array}{c}0.134 \\
\text { (0.110) }\end{array}$ & $\begin{array}{c}0.139 \\
(0.183)\end{array}$ & $\begin{array}{l}-0.497 \\
(0.484)\end{array}$ & $\begin{array}{c}0.089 \\
(0.406)\end{array}$ & $\begin{array}{l}-0.089 \\
(0.296)\end{array}$ \\
\hline Age of head & $\begin{array}{l}-0.004 \\
(0.003)\end{array}$ & $\begin{array}{l}-0.005 \\
(0.004)\end{array}$ & $\begin{array}{c}0.010 \\
(0.041)\end{array}$ & $\begin{array}{c}0.006 \\
(0.012)\end{array}$ & $\begin{array}{l}-0.027^{*} \\
(0.014)\end{array}$ & $\begin{array}{c}0.004 \\
(0.009)\end{array}$ \\
\hline Head education & $\begin{array}{l}-0.029 \\
(0.050)\end{array}$ & $\begin{array}{l}-0.089^{*} \\
(0.051)\end{array}$ & $\begin{array}{c}0.232 \\
(0.350)\end{array}$ & $\begin{array}{l}-0.015 \\
(0.384)\end{array}$ & $\begin{array}{l}0.386^{*} \\
(0.230)\end{array}$ & $\begin{array}{l}-0.101 \\
(0.167)\end{array}$ \\
\hline Agricultural asset wealth & $\begin{array}{l}-0.014 \\
(0.017)\end{array}$ & $\begin{array}{l}-0.026 \\
(0.017)\end{array}$ & $\begin{array}{l}-0.068 \\
(0.198)\end{array}$ & $\begin{array}{l}-0.105 \\
(0.078)\end{array}$ & $\begin{array}{c}0.047 \\
(0.079)\end{array}$ & $\begin{array}{c}0.004 \\
(0.054)\end{array}$ \\
\hline Credit access ( $1=$ Yes) & $\begin{array}{c}0.007 \\
(0.042)\end{array}$ & $\begin{array}{l}-0.072^{*} \\
(0.041)\end{array}$ & $\begin{array}{c}0.025 \\
(0.382)\end{array}$ & $\begin{array}{l}-0.067 \\
(0.256)\end{array}$ & $\begin{array}{l}-0.045 \\
(0.166)\end{array}$ & $\begin{array}{c}0.027 \\
(0.124)\end{array}$ \\
\hline Livestock holdings (log) & $\begin{array}{l}-0.002 \\
(0.008)\end{array}$ & $\begin{array}{c}0.008 \\
(0.008)\end{array}$ & $\begin{array}{c}0.076 \\
(0.055)\end{array}$ & $\begin{array}{c}0.034 \\
(0.042)\end{array}$ & $\begin{array}{l}-0.068^{*} \\
(0.038)\end{array}$ & $\begin{array}{l}-0.036 \\
(0.030)\end{array}$ \\
\hline Land size (log) & $\begin{array}{c}0.006 \\
(0.015)\end{array}$ & $\begin{array}{l}-0.007 \\
(0.023)\end{array}$ & $\begin{array}{c}-0.076 \\
(0.230)\end{array}$ & $\begin{array}{l}-0.051 \\
(0.111)\end{array}$ & $\begin{array}{c}0.047 \\
(0.103)\end{array}$ & $\begin{array}{c}0.065 \\
(0.081)\end{array}$ \\
\hline Distance to road & $\begin{array}{l}-0.000 \\
(0.000)\end{array}$ & $\begin{array}{l}-0.002^{* *} \\
(0.001)\end{array}$ & $\begin{array}{c}0.007 \\
(0.009)\end{array}$ & $\begin{array}{c}0.002 \\
(0.005)\end{array}$ & $\begin{array}{l}-0.002 \\
(0.003)\end{array}$ & $\begin{array}{l}-0.001 \\
(0.002)\end{array}$ \\
\hline Distance to market & $\begin{array}{c}0.001^{* * *} \\
(0.000)\end{array}$ & $\begin{array}{c}0.001^{* * *} \\
(0.000)\end{array}$ & $\begin{array}{l}0.003^{* *} \\
(0.002)\end{array}$ & $\begin{array}{c}0.001 \\
(0.002)\end{array}$ & $\begin{array}{l}0.002^{* *} \\
(0.001)\end{array}$ & $\begin{array}{l}0.003^{* *} \\
(0.001)\end{array}$ \\
\hline No soil nutrient constraint & $\begin{array}{l}-0.062^{* *} \\
(0.026)\end{array}$ & $\begin{array}{l}-0.069^{* *} \\
(0.028)\end{array}$ & $\begin{array}{c}0.114 \\
(0.215)\end{array}$ & $\begin{array}{c}0.098 \\
(0.137)\end{array}$ & $\begin{array}{l}-0.038 \\
(0.107)\end{array}$ & $\begin{array}{l}-0.035 \\
(0.091)\end{array}$ \\
\hline Good quality soil plots & $\begin{array}{c}0.005 \\
\text { (0.010) }\end{array}$ & $\begin{array}{l}-0.011 \\
(0.011)\end{array}$ & $\begin{array}{l}-0.011 \\
(0.102)\end{array}$ & $\begin{array}{l}-0.064 \\
(0.043)\end{array}$ & $\begin{array}{c}0.037 \\
(0.049)\end{array}$ & $\begin{array}{c}0.021 \\
(0.032)\end{array}$ \\
\hline Poor soil quality plots & $\begin{array}{c}0.011 \\
(0.015)\end{array}$ & $\begin{array}{l}-0.008 \\
(0.013)\end{array}$ & $\begin{array}{c}0.072 \\
(0.103)\end{array}$ & $\begin{array}{l}-0.051 \\
(0.065)\end{array}$ & $\begin{array}{l}-0.010 \\
(0.071)\end{array}$ & $\begin{array}{l}-0.042 \\
(0.039)\end{array}$ \\
\hline Organic fertilizer & $\begin{array}{l}0.105^{* *} \\
(0.045)\end{array}$ & $\begin{array}{l}-0.037 \\
(0.044)\end{array}$ & $\begin{array}{l}-0.405 \\
(0.273)\end{array}$ & $\begin{array}{c}0.138 \\
(0.157)\end{array}$ & $\begin{array}{l}-0.151 \\
(0.171)\end{array}$ & $\begin{array}{c}0.065 \\
(0.103)\end{array}$ \\
\hline Price rise of farm inputs & $\begin{array}{l}-0.014 \\
(0.044)\end{array}$ & $\begin{array}{l}-0.042 \\
(0.046)\end{array}$ & $\begin{array}{c}0.332 \\
(0.362)\end{array}$ & $\begin{array}{l}-0.190 \\
(0.233)\end{array}$ & $\begin{array}{c}0.081 \\
(0.181)\end{array}$ & $\begin{array}{l}-0.002 \\
(0.139)\end{array}$ \\
\hline Mean temperature & $\begin{array}{l}0.011^{* *} \\
(0.005)\end{array}$ & $\begin{array}{c}0.027^{* * *} \\
(0.004)\end{array}$ & $\begin{array}{l}-0.035 \\
(0.035)\end{array}$ & $\begin{array}{c}0.024 \\
(0.038)\end{array}$ & $\begin{array}{l}-0.007 \\
(0.016)\end{array}$ & $\begin{array}{l}0.035^{* *} \\
(0.017)\end{array}$ \\
\hline Rainfall previous year & $\begin{array}{c}0.000 \\
(0.000)\end{array}$ & $\begin{array}{l}-0.000 \\
(0.000)\end{array}$ & $\begin{array}{l}-0.001 \\
(0.002)\end{array}$ & $\begin{array}{l}-0.000 \\
(0.001)\end{array}$ & $\begin{array}{l}-0.000 \\
(0.001)\end{array}$ & $\begin{array}{l}-0.001 \\
(0.001)\end{array}$ \\
\hline Average rainfall & $\begin{array}{c}-0.001^{* * *} \\
(0.000)\end{array}$ & $\begin{array}{c}0.000 \\
(0.000)\end{array}$ & $\begin{array}{l}-0.003 \\
(0.003)\end{array}$ & $\begin{array}{c}0.002 \\
(0.002)\end{array}$ & $\begin{array}{l}-0.001 \\
(0.001)\end{array}$ & $\begin{array}{c}0.000 \\
(0.001)\end{array}$ \\
\hline Standard deviation of rainfall & $\begin{array}{l}-0.000 \\
(0.000)\end{array}$ & $\begin{array}{l}0.001^{* *} \\
(0.001)\end{array}$ & $\begin{array}{c}0.002 \\
(0.006)\end{array}$ & $\begin{array}{c}0.000 \\
(0.004)\end{array}$ & $\begin{array}{c}0.000 \\
(0.002)\end{array}$ & $\begin{array}{c}0.000 \\
(0.002)\end{array}$ \\
\hline
\end{tabular}


Table A.5 ...continued

\begin{tabular}{lcccccc}
\hline \hline & $\mathrm{T}_{0} R_{0} C_{0}$ & $\mathrm{~T}_{1} R_{0} C_{0}$ & $\mathrm{~T}_{0} R_{1} C_{0}$ & $\mathrm{~T}_{0} R_{0} C_{1}$ & $\mathrm{~T}_{1} R_{1} C_{0}$ & $\mathrm{~T}_{1} R_{0} C_{1}$ \\
\hline Mundlak variables & $21.88^{*}$ & $24.30^{* *}$ & $19.08^{*}$ & 9.46 & 27.35 *** & 12.86 \\
Year (=2015/16) & -0.018 & -0.080 & -1.327 & 0.289 & -0.409 & -0.077 \\
& $(0.048)$ & $(0.082)$ & $(1.475)$ & $(0.469)$ & $(0.656)$ & $(0.269)$ \\
$\mathrm{IMR}$ & $-0.397^{* * *}$ & $0.287^{*}$ & -0.424 & -0.090 & 0.026 & $0.409^{*}$ \\
& $(0.111)$ & $(0.150)$ & $(0.792)$ & $(0.661)$ & $(0.313)$ & $(0.244)$ \\
IMR X Year & 0.045 & 0.032 & 0.487 & -0.202 & 0.299 & 0.014 \\
& $(0.054)$ & $(0.077)$ & $(0.539)$ & $(0.216)$ & $(0.294)$ & $(0.147)$ \\
Constant & -0.134 & $-1.045^{* * *}$ & 1.223 & -0.613 & -0.578 & $-1.490^{*}$ \\
& $(0.115)$ & $(0.238)$ & $(2.895)$ & $(2.419)$ & $(0.824)$ & $(0.892)$ \\
Region & $Y e s$ & $Y e s$ & $Y e s$ & $Y e s$ & $Y e s$ & $Y e s$ \\
\hline Observations & 2661 & 2537 & 104 & 180 & 230 & 336 \\
Replications & 500 & 500 & 500 & 500 & 500 & 500 \\
\hline \hline
\end{tabular}

Note: $\mathrm{T}, \mathrm{R}$ and $\mathrm{C}$ refer to minimum tillage, crop residue retention and cereal-legume intercropping.

The subscripts ' $\mathrm{o}$ ' and ' 1 ' denote use and non use, respectively. Bootstrapped robust standard errors in parentheses; ${ }^{*} p<0.10,{ }^{* *} p<0.05,{ }^{* * *} p<0.01$. 
Table A.6: Poverty gap equation estimates

\begin{tabular}{|c|c|c|c|c|c|c|}
\hline & $\mathrm{T}_{0} R_{0} \mathrm{C}_{0}$ & $\mathrm{~T}_{1} R_{0} C_{0}$ & $\mathrm{~T}_{0} R_{1} C_{0}$ & $\mathrm{~T}_{0} R_{0} C_{1}$ & $\mathrm{~T}_{1} R_{1} C_{0}$ & $\mathrm{~T}_{1} R_{0} \mathrm{C}_{1}$ \\
\hline Household size & $\begin{array}{c}0.036^{* * *} \\
(0.007)\end{array}$ & $\begin{array}{c}0.031^{* * *} \\
(0.007)\end{array}$ & $\begin{array}{c}0.042 \\
(0.072)\end{array}$ & $\begin{array}{c}0.053 \\
(0.062)\end{array}$ & $\begin{array}{c}0.005 \\
(0.024)\end{array}$ & $\begin{array}{c}0.033 \\
(0.028)\end{array}$ \\
\hline Male headed & $\begin{array}{l}-0.023 \\
(0.036)\end{array}$ & $\begin{array}{c}0.055 \\
(0.048)\end{array}$ & $\begin{array}{c}0.132 \\
(0.089)\end{array}$ & $\begin{array}{l}-0.314 \\
(0.224)\end{array}$ & $\begin{array}{c}0.008 \\
(0.267)\end{array}$ & $\begin{array}{l}-0.098 \\
(0.162)\end{array}$ \\
\hline Age of head & $\begin{array}{l}-0.001 \\
(0.001)\end{array}$ & $\begin{array}{l}-0.003 \\
(0.002)\end{array}$ & $\begin{array}{c}0.006 \\
(0.022)\end{array}$ & $\begin{array}{l}-0.000 \\
(0.008)\end{array}$ & $\begin{array}{l}-0.010 \\
(0.007)\end{array}$ & $\begin{array}{c}0.001 \\
(0.004)\end{array}$ \\
\hline Head education & $\begin{array}{l}-0.020 \\
(0.019)\end{array}$ & $\begin{array}{l}-0.041^{*} \\
(0.022)\end{array}$ & $\begin{array}{c}0.141 \\
(0.175)\end{array}$ & $\begin{array}{l}-0.011 \\
(0.200)\end{array}$ & $\begin{array}{c}0.051 \\
(0.102)\end{array}$ & $\begin{array}{l}-0.050 \\
(0.080)\end{array}$ \\
\hline Agricultural asset wealth & $\begin{array}{c}0.001 \\
(0.007)\end{array}$ & $\begin{array}{l}-0.019^{* *} \\
(0.008)\end{array}$ & $\begin{array}{l}-0.036 \\
(0.083)\end{array}$ & $\begin{array}{c}0.008 \\
(0.035)\end{array}$ & $\begin{array}{c}0.024 \\
(0.037)\end{array}$ & $\begin{array}{l}-0.028 \\
(0.027)\end{array}$ \\
\hline Credit access & $\begin{array}{c}0.005 \\
(0.016)\end{array}$ & $\begin{array}{l}-0.037^{* *} \\
(0.017)\end{array}$ & $\begin{array}{c}0.090 \\
(0.191)\end{array}$ & $\begin{array}{l}-0.043 \\
(0.104)\end{array}$ & $\begin{array}{l}-0.036 \\
(0.070)\end{array}$ & $\begin{array}{l}-0.015 \\
(0.060)\end{array}$ \\
\hline Livestock holdings (log) & $\begin{array}{l}-0.001 \\
(0.003)\end{array}$ & $\begin{array}{l}-0.004 \\
(0.004)\end{array}$ & $\begin{array}{c}0.026 \\
(0.025)\end{array}$ & $\begin{array}{c}0.019 \\
(0.019)\end{array}$ & $\begin{array}{l}-0.005 \\
(0.012)\end{array}$ & $\begin{array}{l}-0.019 \\
(0.015)\end{array}$ \\
\hline Land size (log) & $\begin{array}{l}-0.001 \\
(0.006)\end{array}$ & $\begin{array}{l}-0.010 \\
\text { (0.010) }\end{array}$ & $\begin{array}{l}-0.029 \\
(0.099)\end{array}$ & $\begin{array}{c}0.005 \\
(0.053)\end{array}$ & $\begin{array}{c}0.000 \\
(0.043)\end{array}$ & $\begin{array}{l}-0.026 \\
(0.042)\end{array}$ \\
\hline Distance to road & $\begin{array}{l}-0.000^{*} \\
(0.000)\end{array}$ & $\begin{array}{c}-0.001^{* * *} \\
(0.000)\end{array}$ & $\begin{array}{l}-0.001 \\
(0.004)\end{array}$ & $\begin{array}{c}-0.005^{* *} \\
(0.002)\end{array}$ & $\begin{array}{c}0.000 \\
(0.001)\end{array}$ & $\begin{array}{c}-0.002^{* *} \\
(0.001)\end{array}$ \\
\hline Distance to market & $\begin{array}{l}\mathrm{O}^{0001^{* * *}} \\
(0.000)\end{array}$ & $\begin{array}{c}0.001^{* * *} \\
(0.000)\end{array}$ & $\begin{array}{c}0.003^{* * *} \\
(0.001)\end{array}$ & $\begin{array}{l}0.001^{* *} \\
(0.001)\end{array}$ & $\begin{array}{c}0.001^{* * *} \\
(0.000)\end{array}$ & $\begin{array}{c}0.002^{* * *} \\
(0.001)\end{array}$ \\
\hline No soil nutrient constraint & $\begin{array}{l}-0.015 \\
(0.011)\end{array}$ & $\begin{array}{l}-0.018 \\
(0.013)\end{array}$ & $\begin{array}{c}0.014 \\
(0.118)\end{array}$ & $\begin{array}{c}0.034 \\
(0.056)\end{array}$ & $\begin{array}{l}-0.048 \\
(0.051)\end{array}$ & $\begin{array}{l}-0.046 \\
(0.048)\end{array}$ \\
\hline Good quality soil plots & $\begin{array}{c}0.003 \\
(0.004)\end{array}$ & $\begin{array}{l}-0.005 \\
(0.004)\end{array}$ & $\begin{array}{l}-0.055 \\
(0.048)\end{array}$ & $\begin{array}{l}-0.028 \\
(0.021)\end{array}$ & $\begin{array}{c}0.014 \\
(0.022)\end{array}$ & $\begin{array}{c}0.012 \\
(0.014)\end{array}$ \\
\hline Poor soil quality plots & $\begin{array}{c}0.001 \\
(0.005)\end{array}$ & $\begin{array}{l}-0.000 \\
(0.005)\end{array}$ & $\begin{array}{c}0.046 \\
(0.044)\end{array}$ & $\begin{array}{l}-0.010 \\
(0.028)\end{array}$ & $\begin{array}{l}-0.019 \\
(0.036)\end{array}$ & $\begin{array}{l}-0.021 \\
(0.018)\end{array}$ \\
\hline Organic fertilizer & $\begin{array}{c}0.025 \\
(0.019)\end{array}$ & $\begin{array}{l}-0.001 \\
(0.019)\end{array}$ & $\begin{array}{l}-0.049 \\
(0.127)\end{array}$ & $\begin{array}{c}0.091 \\
(0.083)\end{array}$ & $\begin{array}{l}-0.040 \\
(0.079)\end{array}$ & $\begin{array}{c}0.031 \\
(0.051)\end{array}$ \\
\hline Price rise of farm inputs & $\begin{array}{l}-0.010 \\
(0.017)\end{array}$ & $\begin{array}{l}-0.004 \\
(0.021)\end{array}$ & $\begin{array}{c}0.238 \\
(0.217)\end{array}$ & $\begin{array}{c}0.012 \\
(0.112)\end{array}$ & $\begin{array}{l}0.129^{*} \\
(0.078)\end{array}$ & $\begin{array}{c}-0.041 \\
(0.068)\end{array}$ \\
\hline Mean temperature & $\begin{array}{c}0.003 \\
(0.002)\end{array}$ & $\begin{array}{c}0.009^{* * *} \\
(0.002)\end{array}$ & $\begin{array}{c}0.010 \\
(0.017)\end{array}$ & $\begin{array}{l}0.029^{*} \\
(0.018)\end{array}$ & $\begin{array}{c}0.000 \\
(0.006)\end{array}$ & $\begin{array}{c}0.023^{* * *} \\
(0.009)\end{array}$ \\
\hline Rainfall previous year & $\begin{array}{c}0.000 \\
(0.000)\end{array}$ & $\begin{array}{l}-0.000 \\
(0.000)\end{array}$ & $\begin{array}{l}-0.001 \\
(0.001)\end{array}$ & $\begin{array}{l}-0.001^{*} \\
(0.001)\end{array}$ & $\begin{array}{l}-0.000 \\
(0.001)\end{array}$ & $\begin{array}{l}-0.001^{*} \\
(0.000)\end{array}$ \\
\hline Average rainfall & $\begin{array}{c}-0.001^{* * *} \\
(0.000)\end{array}$ & $\begin{array}{l}-0.000^{*} \\
(0.000)\end{array}$ & $\begin{array}{l}-0.001 \\
(0.001)\end{array}$ & $\begin{array}{l}-0.000 \\
(0.001)\end{array}$ & $\begin{array}{l}-0.000 \\
(0.001)\end{array}$ & $\begin{array}{l}-0.000 \\
(0.000)\end{array}$ \\
\hline Standard deviation of rainfall & $\begin{array}{c}0.000 \\
(0.000)\end{array}$ & $\begin{array}{l}0.001^{* * *} \\
(0.000)\end{array}$ & $\begin{array}{c}0.002 \\
(0.003)\end{array}$ & $\begin{array}{l}-0.000 \\
(0.002)\end{array}$ & $\begin{array}{c}0.000 \\
(0.001)\end{array}$ & $\begin{array}{l}-0.000 \\
(0.001)\end{array}$ \\
\hline
\end{tabular}


Table A.6 ...continued

\begin{tabular}{lcccccc}
\hline \hline & $\mathrm{T}_{0} R_{0} C_{0}$ & $\mathrm{~T}_{1} R_{0} C_{0}$ & $\mathrm{~T}_{0} R_{1} C_{0}$ & $\mathrm{~T}_{0} R_{0} C_{1}$ & $\mathrm{~T}_{1} R_{1} C_{0}$ & $\mathrm{~T}_{1} R_{0} C_{1}$ \\
\hline Mundlak variables & $34.81^{* * *}$ & $20.04^{*}$ & 9.78 & 12.20 & $22.32^{*}$ & 17.44 \\
Year (=2015/16) & -0.002 & -0.026 & 0.292 & -0.062 & -0.098 & -0.170 \\
& $(0.018)$ & $(0.034)$ & $(0.649)$ & $(0.242)$ & $(0.269)$ & $(0.118)$ \\
IMR & $-0.107^{* *}$ & 0.066 & 0.127 & 0.324 & -0.017 & 0.160 \\
& $(0.045)$ & $(0.064)$ & $(0.382)$ & $(0.309)$ & $(0.144)$ & $(0.125)$ \\
IMR X Year & 0.012 & 0.022 & -0.134 & -0.059 & 0.062 & 0.054 \\
& $(0.022)$ & $(0.032)$ & $(0.241)$ & $(0.110)$ & $(0.124)$ & $(0.065)$ \\
Constant & $-0.144^{* * *}$ & $-0.389^{* * *}$ & -1.046 & -1.562 & -0.330 & -0.656 \\
& $(0.046)$ & $(0.103)$ & $(1.401)$ & $(1.104)$ & $(0.377)$ & $(0.484)$ \\
Region & Yes & Yes & Yes & Yes & Yes & Yes \\
\hline Observations & 2661 & 2537 & 104 & 180 & 230 & 336 \\
Replications & 500 & 500 & 500 & 500 & 500 & 500 \\
\hline \hline
\end{tabular}

Note: $\mathrm{T}, \mathrm{R}$ and $\mathrm{C}$ refer to minimum tillage, crop residue retention and cereal-legume intercropping.

The subscripts ' $O$ ' and ' 1 ' denote use and non use, respectively. Standard errors in parentheses.

${ }^{*} p<0.10,{ }^{* *} p<0.05,{ }^{* * *} p<0.01$. 
Table A.7: Poverty severity equation estimates

\begin{tabular}{|c|c|c|c|c|c|c|}
\hline & $\mathrm{T}_{0} R_{0} C_{0}$ & $\mathrm{~T}_{1} R_{0} \mathrm{C}_{0}$ & $\mathrm{~T}_{0} R_{1} C_{0}$ & $\mathrm{~T}_{0} R_{0} C_{1}$ & $\mathrm{~T}_{1} R_{1} C_{0}$ & $\mathrm{~T}_{1} R_{0} \mathrm{C}_{1}$ \\
\hline Household size & $\begin{array}{l}0.018^{* * *} \\
(0.004)\end{array}$ & $\begin{array}{l}0.014^{* * *} \\
(0.004)\end{array}$ & $\begin{array}{l}-0.014 \\
(0.047)\end{array}$ & $\begin{array}{c}0.028 \\
(0.040)\end{array}$ & $\begin{array}{c}\text { 0.001 } \\
(0.016)\end{array}$ & $\begin{array}{c}0.023 \\
(0.018)\end{array}$ \\
\hline Male headed & $\begin{array}{l}-0.025 \\
(0.020)\end{array}$ & $\begin{array}{c}0.031 \\
(0.028)\end{array}$ & $\begin{array}{l}0.111^{* *} \\
(0.056)\end{array}$ & $\begin{array}{l}-0.125 \\
(0.148)\end{array}$ & $\begin{array}{c}-0.024 \\
(0.180)\end{array}$ & $\begin{array}{l}-0.079 \\
(0.108)\end{array}$ \\
\hline Age of head & $\begin{array}{l}-0.001 \\
(0.001)\end{array}$ & $\begin{array}{l}-0.001 \\
(0.001)\end{array}$ & $\begin{array}{c}0.004 \\
(0.013)\end{array}$ & $\begin{array}{c}-0.002 \\
(0.006)\end{array}$ & $\begin{array}{l}-0.005 \\
(0.005)\end{array}$ & $\begin{array}{c}-0.001 \\
(0.003)\end{array}$ \\
\hline Head education & $\begin{array}{l}-0.008 \\
(0.011)\end{array}$ & $\begin{array}{l}-0.030^{* *} \\
(0.013)\end{array}$ & $\begin{array}{c}0.084 \\
(0.115)\end{array}$ & $\begin{array}{l}-0.026 \\
(0.135)\end{array}$ & $\begin{array}{c}0.030 \\
(0.068)\end{array}$ & $\begin{array}{l}-0.018 \\
(0.053)\end{array}$ \\
\hline Agricultural asset wealth & $\begin{array}{c}0.002 \\
(0.004)\end{array}$ & $\begin{array}{c}-0.013^{* * *} \\
(0.005)\end{array}$ & $\begin{array}{l}-0.015 \\
(0.051)\end{array}$ & $\begin{array}{c}0.018 \\
(0.024)\end{array}$ & $\begin{array}{c}0.015 \\
(0.023)\end{array}$ & $\begin{array}{l}-0.029 \\
(0.018)\end{array}$ \\
\hline Credit access & $\begin{array}{c}0.005 \\
(0.009)\end{array}$ & $\begin{array}{l}-0.016 \\
\text { (0.010) }\end{array}$ & $\begin{array}{c}0.057 \\
(0.116)\end{array}$ & $\begin{array}{l}-0.016 \\
(0.071)\end{array}$ & $\begin{array}{l}-0.024 \\
(0.044)\end{array}$ & $\begin{array}{l}-0.016 \\
(0.041)\end{array}$ \\
\hline Livestock holdings (log) & $\begin{array}{c}-0.001 \\
(0.002)\end{array}$ & $\begin{array}{l}-0.003 \\
(0.002)\end{array}$ & $\begin{array}{c}0.012 \\
(0.016)\end{array}$ & $\begin{array}{c}0.007 \\
(0.012)\end{array}$ & $\begin{array}{c}0.003 \\
(0.007)\end{array}$ & $\begin{array}{l}-0.011 \\
(0.010)\end{array}$ \\
\hline Land size (log) & $\begin{array}{l}-0.001 \\
(0.003)\end{array}$ & $\begin{array}{l}-0.006 \\
(0.006)\end{array}$ & $\begin{array}{l}-0.013 \\
(0.063)\end{array}$ & $\begin{array}{c}0.005 \\
(0.037)\end{array}$ & $\begin{array}{l}-0.006 \\
(0.025)\end{array}$ & $\begin{array}{l}-0.030 \\
(0.028)\end{array}$ \\
\hline Distance to road & $\begin{array}{c}-0.000^{* * *} \\
(0.000)\end{array}$ & $\begin{array}{c}-0.001^{* * *} \\
(0.000)\end{array}$ & $\begin{array}{l}-0.002 \\
(0.003)\end{array}$ & $\begin{array}{c}-0.004^{* * *} \\
(0.002)\end{array}$ & $\begin{array}{c}0.000 \\
(0.001)\end{array}$ & $\begin{array}{c}-0.002^{* * *} \\
(0.001)\end{array}$ \\
\hline Distance to market & $\begin{array}{c}0.000^{* * *} \\
(0.000)\end{array}$ & $\begin{array}{l}0.001^{* * *} \\
(0.000)\end{array}$ & $\begin{array}{l}0.002^{* * *} \\
(0.001)\end{array}$ & $\begin{array}{l}0.001^{* * *} \\
(0.000)\end{array}$ & $\begin{array}{l}\mathrm{O}^{0001^{* * *}} \\
(0.000)\end{array}$ & $\begin{array}{l}0.001^{* * *} \\
(0.000)\end{array}$ \\
\hline No soil nutrient constraint & $\begin{array}{l}-0.007 \\
(0.007)\end{array}$ & $\begin{array}{l}-0.009 \\
(0.008)\end{array}$ & $\begin{array}{c}0.012 \\
(0.074)\end{array}$ & $\begin{array}{c}0.022 \\
(0.035)\end{array}$ & $\begin{array}{l}-0.030 \\
(0.032)\end{array}$ & $\begin{array}{l}-0.031 \\
(0.032)\end{array}$ \\
\hline Good quality soil plots & $\begin{array}{c}0.001 \\
(0.002)\end{array}$ & $\begin{array}{l}-0.002 \\
(0.002)\end{array}$ & $\begin{array}{l}-0.040 \\
(0.029)\end{array}$ & $\begin{array}{l}-0.017 \\
(0.014)\end{array}$ & $\begin{array}{c}0.006 \\
(0.013)\end{array}$ & $\begin{array}{c}0.008 \\
(0.010)\end{array}$ \\
\hline Poor soil quality plots & $\begin{array}{c}0.001 \\
(0.003)\end{array}$ & $\begin{array}{c}0.000 \\
(0.003)\end{array}$ & $\begin{array}{c}0.026 \\
(0.028)\end{array}$ & $\begin{array}{l}-0.006 \\
(0.019)\end{array}$ & $\begin{array}{l}-0.009 \\
(0.023)\end{array}$ & $\begin{array}{l}-0.010 \\
(0.011)\end{array}$ \\
\hline Organic fertilizer & $\begin{array}{c}0.011 \\
(0.011)\end{array}$ & $\begin{array}{c}0.008 \\
(0.012)\end{array}$ & $\begin{array}{c}0.016 \\
(0.082)\end{array}$ & $\begin{array}{c}0.054 \\
(0.058)\end{array}$ & $\begin{array}{l}-0.026 \\
(0.046)\end{array}$ & $\begin{array}{c}0.011 \\
(0.034)\end{array}$ \\
\hline Price rise of farm inputs & $\begin{array}{l}-0.007 \\
(0.010)\end{array}$ & $\begin{array}{l}-0.001 \\
(0.013)\end{array}$ & $\begin{array}{c}0.170 \\
(0.135)\end{array}$ & $\begin{array}{c}0.024 \\
(0.075)\end{array}$ & $\begin{array}{l}0.084^{*} \\
(0.046)\end{array}$ & $\begin{array}{l}-0.026 \\
(0.048)\end{array}$ \\
\hline Mean temperature & $\begin{array}{c}0.001 \\
(0.001)\end{array}$ & $\begin{array}{c}0.005^{* * *} \\
(0.001)\end{array}$ & $\begin{array}{c}0.016 \\
(0.010)\end{array}$ & $\begin{array}{l}0.026^{* *} \\
(0.012)\end{array}$ & $\begin{array}{c}0.001 \\
(0.004)\end{array}$ & $\begin{array}{l}0.015^{* *} \\
(0.006)\end{array}$ \\
\hline Rainfall previous year & $\begin{array}{l}-0.000 \\
(0.000)\end{array}$ & $\begin{array}{l}-0.000 \\
(0.000)\end{array}$ & $\begin{array}{l}-0.001^{*} \\
(0.001)\end{array}$ & $\begin{array}{l}-0.001^{* *} \\
(0.000)\end{array}$ & $\begin{array}{c}-0.000 \\
(0.000)\end{array}$ & $\begin{array}{l}-0.001^{*} \\
(0.000)\end{array}$ \\
\hline Average rainfall & $\begin{array}{c}-0.000^{* * *} \\
(0.000)\end{array}$ & $\begin{array}{l}-0.000^{* *} \\
(0.000)\end{array}$ & $\begin{array}{l}-0.000 \\
(0.001)\end{array}$ & $\begin{array}{l}-0.000 \\
(0.001)\end{array}$ & $\begin{array}{l}-0.000 \\
(0.000)\end{array}$ & $\begin{array}{l}-0.000 \\
(0.000)\end{array}$ \\
\hline Standard deviation of rainfall & $\begin{array}{c}0.000 \\
(0.000)\end{array}$ & $\begin{array}{c}0.000^{* * *} \\
(0.000)\end{array}$ & $\begin{array}{c}0.002 \\
(0.002)\end{array}$ & $\begin{array}{c}0.000 \\
(0.001)\end{array}$ & $\begin{array}{c}0.000 \\
(0.001)\end{array}$ & $\begin{array}{c}-0.001 \\
(0.001)\end{array}$ \\
\hline
\end{tabular}


Table A.7 ...continued

\begin{tabular}{lcccccc}
\hline \hline & $\mathrm{T}_{0} R_{0} C_{0}$ & $\mathrm{~T}_{1} R_{0} C_{0}$ & $\mathrm{~T}_{0} R_{1} C_{0}$ & $\mathrm{~T}_{0} R_{0} C_{1}$ & $\mathrm{~T}_{1} R_{1} C_{0}$ & $\mathrm{~T}_{1} R_{0} C_{1}$ \\
\hline Mundlak variables & $35.51^{* * *}$ & $17.27^{*}$ & 8.56 & 11.01 & $20.92^{*}$ & 18.64 \\
Year (=2015/16) & 0.001 & -0.017 & 0.349 & -0.172 & -0.030 & -0.126 \\
& $(0.010)$ & $(0.020)$ & $(0.407)$ & $(0.172)$ & $(0.166)$ & $(0.077)$ \\
IMR & $-0.048^{*}$ & 0.039 & 0.132 & 0.226 & 0.001 & 0.073 \\
& $(0.026)$ & $(0.040)$ & $(0.253)$ & $(0.209)$ & $(0.088)$ & $(0.083)$ \\
IMR X Year & 0.005 & 0.016 & -0.165 & 0.010 & 0.016 & 0.038 \\
& $(0.013)$ & $(0.019)$ & $(0.148)$ & $(0.075)$ & $(0.076)$ & $(0.042)$ \\
Constant & $-0.099^{* * *}$ & $-0.236^{* * *}$ & -1.042 & -1.217 & -0.231 & -0.349 \\
& $(0.026)$ & $(0.063)$ & $(0.915)$ & $(0.745)$ & $(0.232)$ & $(0.340)$ \\
Region & Yes & Yes & Yes & Yes & Yes & Yes \\
\hline Replications & 500 & 500 & 500 & 500 & 500 & 500 \\
Observations & 2661 & 2537 & 104 & 180 & 230 & 336 \\
\hline \hline
\end{tabular}

Note: $\mathrm{T}, \mathrm{R}$ and $\mathrm{C}$ refer to minimum tillage, crop residue retention and cereal-legume intercropping. respectively. The subscripts ' $\mathrm{o}$ ' and ' 1 ' denote use and non use, respectively. Standard errors in parentheses. ${ }^{*} p<0.10,{ }^{* *} p<0.05,{ }^{* * *} p<0.01$. 
Table A.8: Estimates of net crop income equations

\begin{tabular}{|c|c|c|c|c|c|c|}
\hline & $\mathrm{T}_{0} R_{0} \mathrm{C}_{0}$ & $\mathrm{~T}_{1} R_{0} C_{0}$ & $\mathrm{~T}_{0} R_{1} C_{0}$ & $\mathrm{~T}_{0} R_{0} C_{1}$ & $\mathrm{~T}_{1} R_{1} C_{0}$ & $\mathrm{~T}_{1} R_{0} C_{1}$ \\
\hline Household size & $\begin{array}{l}-196.751 \\
(399.781)\end{array}$ & $\begin{array}{l}-464.283 \\
(343.291)\end{array}$ & $\begin{array}{c}-171.012 \\
(3655.110)\end{array}$ & $\begin{array}{c}694 \cdot 348 \\
(2705 \cdot 728)\end{array}$ & $\begin{array}{c}-618.433 \\
(1136.401)\end{array}$ & $\begin{array}{c}371.838 \\
(692.448)\end{array}$ \\
\hline Male headed & $\begin{array}{l}-1192.210 \\
(2064.609)\end{array}$ & $\begin{array}{l}-3855.024^{* *} \\
(1878.947)\end{array}$ & $\begin{array}{c}-59.382 \\
(4393.846)\end{array}$ & $\begin{array}{c}-5712.150 \\
(10743.376)\end{array}$ & $\begin{array}{c}2471.908 \\
(6642.111)\end{array}$ & $\begin{array}{c}4.458 \\
(5451.663)\end{array}$ \\
\hline Age of head & $\begin{array}{l}-34.710 \\
(70.056)\end{array}$ & $\begin{array}{c}30.304 \\
(56.236)\end{array}$ & $\begin{array}{c}1146.638 \\
(1524.846)\end{array}$ & $\begin{array}{c}-80.885 \\
(357.729)\end{array}$ & $\begin{array}{c}112.992 \\
(260.750)\end{array}$ & $\begin{array}{c}83.508 \\
(145 \cdot 545)\end{array}$ \\
\hline Head education & $\begin{array}{c}287.224 \\
(1258.756)\end{array}$ & $\begin{array}{l}-1668.089^{*} \\
(936.388)\end{array}$ & $\begin{array}{c}-2076.941 \\
(10074.644)\end{array}$ & $\begin{array}{c}1855.902 \\
(7458.746)\end{array}$ & $\begin{array}{c}5057 \cdot 587 \\
(4239 \cdot 576)\end{array}$ & $\begin{array}{c}-885.708 \\
(2676.223)\end{array}$ \\
\hline Labor days (log) & $\begin{array}{c}1272.321^{* * *} \\
(320.583)\end{array}$ & $\begin{array}{c}1603.139^{* * * *} \\
(306.306)\end{array}$ & $\begin{array}{l}-1529.299 \\
(3221.756)\end{array}$ & $\begin{array}{c}2050.579 \\
(1355.563)\end{array}$ & $\begin{array}{c}880.202 \\
(1440.537)\end{array}$ & $\begin{array}{c}1944.040^{* *} \\
(827.364)\end{array}$ \\
\hline Agricultural asset wealth & $\begin{array}{c}1051.390^{* * *} \\
(390.183)\end{array}$ & $\begin{array}{c}516.428 \\
(348.012)\end{array}$ & $\begin{array}{l}-2828.332 \\
(3842.957)\end{array}$ & $\begin{array}{l}3550.351^{* *} \\
(1649.872)\end{array}$ & $\begin{array}{l}-1651.327 \\
(1667.021)\end{array}$ & $\begin{array}{l}-774.870 \\
(865.678)\end{array}$ \\
\hline Credit access & $\begin{array}{l}-714.084 \\
(824.074)\end{array}$ & $\begin{array}{c}219.718 \\
(613 \cdot 345)\end{array}$ & $\begin{array}{l}11760.498 \\
(9141.270)\end{array}$ & $\begin{array}{c}2661.471 \\
(3918.754)\end{array}$ & $\begin{array}{l}-1590.205 \\
(3424.552)\end{array}$ & $\begin{array}{c}2106.766 \\
(1490.185)\end{array}$ \\
\hline Livestock holdings (log) & $\begin{array}{c}56.348 \\
(203.547)\end{array}$ & $\begin{array}{c}76.385 \\
(205.828)\end{array}$ & $\begin{array}{c}1793.839 \\
(1574.534)\end{array}$ & $\begin{array}{l}-668.712 \\
(669.645)\end{array}$ & $\begin{array}{c}476.891 \\
(629 \cdot 391)\end{array}$ & $\begin{array}{l}-607.812 \\
(459.743)\end{array}$ \\
\hline Land size (log) & $\begin{array}{c}-2460.354^{* * * *} \\
(536.293)\end{array}$ & $\begin{array}{c}-2199.007^{* * *} \\
(554.601)\end{array}$ & $\begin{array}{l}-6410.986 \\
(5261.310)\end{array}$ & $\begin{array}{l}-5002.507^{*} \\
(2979.809)\end{array}$ & $\begin{array}{l}-4353 \cdot 371^{*} \\
(2354.642)\end{array}$ & $\begin{array}{c}-4051.341^{* * *} \\
(1060.449)\end{array}$ \\
\hline Distance to road, $\mathrm{Km}$ & $\begin{array}{c}-48.947^{* * *} \\
(12.507)\end{array}$ & $\begin{array}{r}-13.486 \\
(11.241)\end{array}$ & $\begin{array}{l}-127 \cdot 333 \\
(285.830)\end{array}$ & $\begin{array}{c}-31.758 \\
(113.319)\end{array}$ & $\begin{array}{c}14.557 \\
(44.127)\end{array}$ & $\begin{array}{c}-3.933 \\
(33.531)\end{array}$ \\
\hline Distance to market & $\begin{array}{c}24.806^{* * *} \\
(9.092)\end{array}$ & $\begin{array}{c}-15.687^{* * *} \\
(5.835)\end{array}$ & $\begin{array}{l}-30.979 \\
(50.579)\end{array}$ & $\begin{array}{l}-12.543 \\
(29.884)\end{array}$ & $\begin{array}{l}-31.009^{*} \\
(18.222)\end{array}$ & $\begin{array}{l}-38.603^{*} \\
(22.481)\end{array}$ \\
\hline Inorganic fertilizer & $\begin{array}{c}397.994 \\
(1098.665)\end{array}$ & $\begin{array}{l}-1065.569 \\
(902.270)\end{array}$ & $\begin{array}{l}-2252.234 \\
(6856.218)\end{array}$ & $\begin{array}{l}-5907.172^{*} \\
(3167.826)\end{array}$ & $\begin{array}{l}-2052.481 \\
(3512.289)\end{array}$ & $\begin{array}{c}1165.342 \\
(1536.001)\end{array}$ \\
\hline Organic fertilizer & $\begin{array}{l}2082.507^{*} \\
(1063.816)\end{array}$ & $\begin{array}{c}-1672.729^{* *} \\
(764.286)\end{array}$ & $\begin{array}{c}480.508 \\
(8196.525)\end{array}$ & $\begin{array}{l}-1932.542 \\
(2885.977)\end{array}$ & $\begin{array}{l}-1331.059 \\
(3316.755)\end{array}$ & $\begin{array}{c}-121.836 \\
(2061.536)\end{array}$ \\
\hline No soil nutrient constraint & $\begin{array}{c}-1627.195^{* *} \\
(779.397)\end{array}$ & $\begin{array}{c}439.711 \\
(515.586)\end{array}$ & $\begin{array}{c}2536.438 \\
(6983.656)\end{array}$ & $\begin{array}{c}-348.547 \\
(2440.043)\end{array}$ & $\begin{array}{l}3451.200^{*} \\
(2024.978)\end{array}$ & $\begin{array}{c}-555.459 \\
(1268.836)\end{array}$ \\
\hline Good quality soil plots & $\begin{array}{c}15.088 \\
(190.139)\end{array}$ & $\begin{array}{c}-6.048 \\
(194.469)\end{array}$ & $\begin{array}{c}-218.874 \\
(2386.471)\end{array}$ & $\begin{array}{l}-306.980 \\
(680.228)\end{array}$ & $\begin{array}{c}-96.753 \\
(958.213)\end{array}$ & $\begin{array}{l}-343.408 \\
(345.044)\end{array}$ \\
\hline Poor soil quality plots & $\begin{array}{c}381.977 \\
(238.553)\end{array}$ & $\begin{array}{c}311.715 \\
(208.204)\end{array}$ & $\begin{array}{c}1276.296 \\
(2533.467)\end{array}$ & $\begin{array}{l}1142.839 \\
(938.912)\end{array}$ & $\begin{array}{c}-503.141 \\
(1164.884)\end{array}$ & $\begin{array}{c}287.270 \\
(568.040)\end{array}$ \\
\hline Price rise of farm inputs & $\begin{array}{c}-2830.146^{* * *} \\
(952.513)\end{array}$ & $\begin{array}{l}1040.898 \\
(774.079)\end{array}$ & $\begin{array}{l}-2597.827 \\
(9006.248)\end{array}$ & $\begin{array}{c}-806.892 \\
(4423.134)\end{array}$ & $\begin{array}{c}2757 \cdot 322 \\
(3049.102)\end{array}$ & $\begin{array}{l}5796.897^{* * *} \\
(1949.368)\end{array}$ \\
\hline Mean temperature & $\begin{array}{c}148.637 \\
(141.131)\end{array}$ & $\begin{array}{c}65.690 \\
(75.633)\end{array}$ & $\begin{array}{c}647.950 \\
(955.681)\end{array}$ & $\begin{array}{c}-26.845 \\
(790.155)\end{array}$ & $\begin{array}{l}-226.116 \\
(266.683)\end{array}$ & $\begin{array}{l}-165.603 \\
(279.193)\end{array}$ \\
\hline Rainfall previous year & $\begin{array}{c}5 \cdot 375 \\
(4.939)\end{array}$ & $\begin{array}{c}4.974 \\
(4.001)\end{array}$ & $\begin{array}{l}-18.147 \\
(45.675)\end{array}$ & $\begin{array}{c}31.500 \\
(20.997)\end{array}$ & $\begin{array}{l}-42.786^{* *} \\
(18.188)\end{array}$ & $\begin{array}{c}9.551 \\
(10.497)\end{array}$ \\
\hline Average rainfall & $\begin{array}{c}-22.441^{* * *} \\
(8.089)\end{array}$ & $\begin{array}{c}-19.428^{* * * *} \\
(5.038)\end{array}$ & $\begin{array}{c}15.637 \\
(68.835)\end{array}$ & $\begin{array}{l}-19.658 \\
(48.865)\end{array}$ & $\begin{array}{c}25.864 \\
(28.384)\end{array}$ & $\begin{array}{c}3.366 \\
(15.105)\end{array}$ \\
\hline Standard deviation of rainfall & $\begin{array}{l}23 \cdot 747^{* *} \\
(10.674)\end{array}$ & $\begin{array}{l}-15.341 \\
(9.681)\end{array}$ & $\begin{array}{c}72.941 \\
(142.428)\end{array}$ & $\begin{array}{l}-75.673 \\
(73.791)\end{array}$ & $\begin{array}{l}-69.779^{*} \\
(38.423)\end{array}$ & $\begin{array}{l}-26.544 \\
(36.821)\end{array}$ \\
\hline Mundlak variables & $33.15^{* * *}$ & $30.53^{* *}$ & 4.55 & 12.48 & 11.48 & 16.02 \\
\hline Year $(=2015 / 16)$ & $\begin{array}{c}1739.941 \\
(1519.790)\end{array}$ & $\begin{array}{c}547.002 \\
(1712.170)\end{array}$ & $\begin{array}{c}-1.24 \mathrm{e}+04 \\
(39017.080)\end{array}$ & $\begin{array}{c}9535.789 \\
(7798.773) \\
\end{array}$ & $\begin{array}{c}4529.843 \\
(9680.480)\end{array}$ & $\begin{array}{c}5668.081 \\
(3678.269)\end{array}$ \\
\hline
\end{tabular}


Table A.8 ...continued

\begin{tabular}{lcccccc}
\hline \hline & $\mathrm{T}_{0} R_{0} C_{0}$ & $\mathrm{~T}_{1} R_{0} C_{0}$ & $\mathrm{~T}_{0} R_{1} C_{0}$ & $\mathrm{~T}_{0} R_{0} C_{1}$ & $\mathrm{~T}_{1} R_{1} C_{0}$ & $\mathrm{~T}_{1} R_{0} C_{1}$ \\
\hline IMR & $-1.13 \mathrm{e}+04^{* * *}$ & $-7576.402^{* *}$ & 935.876 & 3659.136 & 7822.636 & -3870.308 \\
& $(3655.358)$ & $(3108.336)$ & $(21836.732)$ & $(12407.070)$ & $(4765.074)$ & $(4487.060)$ \\
IMR X Year & $-4981.260^{* * *}$ & 2027.845 & 3623.821 & -1492.845 & -3640.901 & $-3313.738^{*}$ \\
& $(1475.940)$ & $(1658.302)$ & $(15257.266)$ & $(3379.121)$ & $(4698.758)$ & $(1936.301)$ \\
Constant & -4513.284 & 5987.795 & 1681.493 & 1500.294 & $-1.05 \mathrm{e}+04$ & 16460.630 \\
& $(3039.072)$ & $(4652.009)$ & $(71921.761)$ & $(46005.919)$ & $(13410.366)$ & $(15201.083)$ \\
Region & Yes & Yes & Yes & Yes & Yes & Yes \\
\hline Observations & 1,947 & 2,453 & 99 & 177 & 220 & 334 \\
\hline \hline
\end{tabular}

Note: T, R and C refer to minimum tillage, crop residue retention and cereal-legume intercropping. respectively. The subscripts ' $\mathrm{o}$ ' and ' 1 ' denote use and non use, respectively. Standard errors in parentheses. ${ }^{*} p<0.10,{ }^{* *} p<0.05,{ }^{* * *} p<0.01$. 
Table A.9: Estimates of cost of production equations

\begin{tabular}{|c|c|c|c|c|c|c|}
\hline & $\mathrm{T}_{0} R_{0} C_{0}$ & $\mathrm{~T}_{1} R_{0} \mathrm{C}_{0}$ & $\mathrm{~T}_{0} R_{1} C_{0}$ & $\mathrm{~T}_{0} R_{0} C_{1}$ & $\mathrm{~T}_{1} R_{1} C_{0}$ & $\mathrm{~T}_{1} R_{0} C_{1}$ \\
\hline Household size & $\begin{array}{c}170.954^{* * *} \\
(64.789)\end{array}$ & $\begin{array}{c}74.351 \\
(51.125)\end{array}$ & $\begin{array}{c}-72.409 \\
(344.042)\end{array}$ & $\begin{array}{l}353.409^{*} \\
(214.017)\end{array}$ & $\begin{array}{c}45 \cdot 572 \\
(158.371)\end{array}$ & $\begin{array}{l}-21.659 \\
(95.106)\end{array}$ \\
\hline Male headed & $\begin{array}{c}194.738 \\
(348.770)\end{array}$ & $\begin{array}{c}54.020 \\
(235.058)\end{array}$ & $\begin{array}{c}-96.289 \\
(502.865)\end{array}$ & $\begin{array}{l}-181.537 \\
(641.449)\end{array}$ & $\begin{array}{l}-137.999 \\
(548.761)\end{array}$ & $\begin{array}{c}607.260 \\
(420.075)\end{array}$ \\
\hline Age of head & $\begin{array}{c}-5.506 \\
(12.043)\end{array}$ & $\begin{array}{l}-26.271^{*} \\
(14.837)\end{array}$ & $\begin{array}{c}42.003 \\
(128.308)\end{array}$ & $\begin{array}{c}-0.167 \\
(25.508)\end{array}$ & $\begin{array}{c}-2.951 \\
(31.684)\end{array}$ & $\begin{array}{c}2.725 \\
(18.201)\end{array}$ \\
\hline Head education & $\begin{array}{c}138.771 \\
(178.174)\end{array}$ & $\begin{array}{c}-65.907 \\
(109.668)\end{array}$ & $\begin{array}{c}-690.593 \\
(1024.194)\end{array}$ & $\begin{array}{c}367.825 \\
(464.616)\end{array}$ & $\begin{array}{l}-351.903 \\
(492.795)\end{array}$ & $\begin{array}{r}-1128.036 \\
(753.476)\end{array}$ \\
\hline Agricultural asset wealth & $\begin{array}{l}-27.105 \\
(67.201)\end{array}$ & $\begin{array}{l}-16.929 \\
(50.481)\end{array}$ & $\begin{array}{c}-88.504 \\
(418.384)\end{array}$ & $\begin{array}{l}-123.349 \\
(114.274)\end{array}$ & $\begin{array}{c}-65.982 \\
(137.770)\end{array}$ & $\begin{array}{c}111.149 \\
(129.038)\end{array}$ \\
\hline Credit access & $\begin{array}{c}4.123 \\
(99.127)\end{array}$ & $\begin{array}{l}-32.536 \\
(86.740)\end{array}$ & $\begin{array}{l}-761.143 \\
(815.540)\end{array}$ & $\begin{array}{c}393.646 \\
(356.369)\end{array}$ & $\begin{array}{c}197.647 \\
(271.165)\end{array}$ & $\begin{array}{c}-41.616 \\
(197.398)\end{array}$ \\
\hline Livestock holdings (log) & $\begin{array}{l}-39.768 \\
(40.436)\end{array}$ & $\begin{array}{l}-15.462 \\
(24.882)\end{array}$ & $\begin{array}{c}45.842 \\
(111.461)\end{array}$ & $\begin{array}{c}35.474 \\
(41.296)\end{array}$ & $\begin{array}{l}-33 \cdot 512 \\
(62.694)\end{array}$ & $\begin{array}{l}297.702^{*} \\
(164.854)\end{array}$ \\
\hline Land size (log) & $\begin{array}{c}-354.599^{* * *} \\
(91.604)\end{array}$ & $\begin{array}{c}-374.944^{* * *} \\
(91.608)\end{array}$ & $\begin{array}{l}-487.952 \\
(526.841)\end{array}$ & $\begin{array}{c}54.636 \\
(138.014)\end{array}$ & $\begin{array}{l}-400.321 * \\
(207.744)\end{array}$ & $\begin{array}{c}-84.841 \\
(182.600)\end{array}$ \\
\hline Distance to road & $\begin{array}{l}-4.750^{* *} \\
(2.359)\end{array}$ & $\begin{array}{c}2.242 \\
(1.589)\end{array}$ & $\begin{array}{c}1.784 \\
(23.466)\end{array}$ & $\begin{array}{l}-12.872 \\
(8.460)\end{array}$ & $\begin{array}{l}-2.352 \\
(6.303)\end{array}$ & $\begin{array}{c}-11.199^{* * * *} \\
(4.251)\end{array}$ \\
\hline Distance to market & $\begin{array}{l}-3.922^{* * *} \\
(1.414)\end{array}$ & $\begin{array}{l}-0.861 \\
(0.702)\end{array}$ & $\begin{array}{l}-0.774 \\
(4.760)\end{array}$ & $\begin{array}{c}0.025 \\
(2.437)\end{array}$ & $\begin{array}{l}-0.398 \\
(1.778)\end{array}$ & $\begin{array}{l}-0.844 \\
(2.082)\end{array}$ \\
\hline No soil nutrient constraint & $\begin{array}{c}67.584 \\
(137.900)\end{array}$ & $\begin{array}{l}-81.442 \\
(76.135)\end{array}$ & $\begin{array}{c}390.989 \\
(712.433)\end{array}$ & $\begin{array}{c}28.742 \\
(143.878)\end{array}$ & $\begin{array}{l}395.668^{*} \\
(207.216)\end{array}$ & $\begin{array}{c}-9.749 \\
(147.730)\end{array}$ \\
\hline Good quality soil plots & $\begin{array}{l}55.247 \\
(35.638)\end{array}$ & $\begin{array}{c}6.598 \\
(22.189)\end{array}$ & $\begin{array}{l}-103.121 \\
(263.505)\end{array}$ & $\begin{array}{l}-105.014^{*} \\
(59.205)\end{array}$ & $\begin{array}{l}-25 \cdot 390 \\
(74 \cdot 310)\end{array}$ & $\begin{array}{l}-14.724 \\
(43.123)\end{array}$ \\
\hline Poor soil quality plots & $\begin{array}{l}-17.635 \\
(38.964)\end{array}$ & $\begin{array}{c}2.603 \\
(22.181)\end{array}$ & $\begin{array}{c}208.829 \\
(226.380)\end{array}$ & $\begin{array}{c}169.435 \\
(132.264)\end{array}$ & $\begin{array}{c}90.029 \\
(127.203)\end{array}$ & $\begin{array}{l}-62.429 \\
(62.645)\end{array}$ \\
\hline Organic fertilizer & $\begin{array}{l}-261.476 \\
(183.239)\end{array}$ & $\begin{array}{l}122.013 \\
(99.286)\end{array}$ & $\begin{array}{l}-437.747 \\
(662.098)\end{array}$ & $\begin{array}{l}-287.724 \\
(247.119)\end{array}$ & $\begin{array}{l}-141.032 \\
(359.206)\end{array}$ & $\begin{array}{l}-146.352 \\
(230.544)\end{array}$ \\
\hline Price rise of farm inputs & $\begin{array}{l}-101.553 \\
(132.075)\end{array}$ & $\begin{array}{l}-123.957 \\
(76.391)\end{array}$ & $\begin{array}{c}247.230 \\
(958.701)\end{array}$ & $\begin{array}{l}-190.599 \\
(455.441)\end{array}$ & $\begin{array}{c}191.712 \\
(400.781)\end{array}$ & $\begin{array}{c}180.061 \\
(284.123)\end{array}$ \\
\hline Mean temperature & $\begin{array}{c}-61.912^{* * * *} \\
(21.640)\end{array}$ & $\begin{array}{c}-35 \cdot 389^{* * * *} \\
(11.686)\end{array}$ & $\begin{array}{c}73.077 \\
(89.043)\end{array}$ & $\begin{array}{l}-53.287 \\
(59.528)\end{array}$ & $\begin{array}{l}-10.396 \\
(40.027)\end{array}$ & $\begin{array}{c}11.550 \\
(36.751)\end{array}$ \\
\hline Rainfall previous year & $\begin{array}{l}-0.658 \\
(0.734)\end{array}$ & $\begin{array}{c}0.473 \\
(0.632)\end{array}$ & $\begin{array}{c}2.708 \\
(4.899)\end{array}$ & $\begin{array}{l}-1.463 \\
(1.466)\end{array}$ & $\begin{array}{c}2.836 \\
(2.239)\end{array}$ & $\begin{array}{l}-1.026 \\
(1.769)\end{array}$ \\
\hline Average rainfall & $\begin{array}{c}0.927 \\
(1.083)\end{array}$ & $\begin{array}{l}-0.816 \\
(0.774)\end{array}$ & $\begin{array}{c}2.874 \\
(7.991)\end{array}$ & $\begin{array}{l}-6.520^{*} \\
(3.923)\end{array}$ & $\begin{array}{l}1.265 \\
(2.437)\end{array}$ & $\begin{array}{l}-1.679 \\
(1.707)\end{array}$ \\
\hline Standard deviation of rainfall & $\begin{array}{l}-1.168 \\
(1.776)\end{array}$ & $\begin{array}{l}-2.872^{* *} \\
(1.330)\end{array}$ & $\begin{array}{c}14.092 \\
(13.943)\end{array}$ & $\begin{array}{c}4.053 \\
(5.560)\end{array}$ & $\begin{array}{c}2.313 \\
(4.945)\end{array}$ & $\begin{array}{l}7.648^{*} \\
(4 \cdot 330)\end{array}$ \\
\hline Mundlak variables & 19.57 & 19.53 & 6.27 & 7.00 & 12.43 & 13.50 \\
\hline Year $(=2015 / 16)$ & $\begin{array}{c}1058.871^{* * *} \\
(242.003)\end{array}$ & $\begin{array}{l}-110.428 \\
(210.842)\end{array}$ & $\begin{array}{l}-1794.507 \\
(3031.686)\end{array}$ & $\begin{array}{c}597.982 \\
(668.972)\end{array}$ & $\begin{array}{c}803.821 \\
(925.550)\end{array}$ & $\begin{array}{c}360.831 \\
(468.402)\end{array}$ \\
\hline IMR & $\begin{array}{c}1426.777^{* * *} \\
(537.979)\end{array}$ & $\begin{array}{l}1103.003^{* *} \\
(443.781)\end{array}$ & $\begin{array}{c}-905.650 \\
(2051.211)\end{array}$ & $\begin{array}{l}1831.424^{*} \\
(1056.405)\end{array}$ & $\begin{array}{c}-68.761 \\
(471.487)\end{array}$ & $\begin{array}{c}371.875 \\
(531.331)\end{array}$ \\
\hline IMR X Year & $\begin{array}{c}-765.825^{* * * *} \\
(233.313)\end{array}$ & $\begin{array}{c}28.843 \\
(263.919)\end{array}$ & $\begin{array}{c}757.146 \\
(1192.250)\end{array}$ & $\begin{array}{c}426.520 \\
(341.274)\end{array}$ & $\begin{array}{l}-184.210 \\
(421.683)\end{array}$ & $\begin{array}{l}-223.330 \\
(312.575)\end{array}$ \\
\hline
\end{tabular}


Table A.9 ...continued

\begin{tabular}{lcccccc}
\hline \hline & $\mathrm{T}_{0} R_{0} C_{0}$ & $\mathrm{~T}_{1} R_{0} C_{0}$ & $\mathrm{~T}_{0} R_{1} C_{0}$ & $\mathrm{~T}_{0} R_{0} C_{1}$ & $\mathrm{~T}_{1} R_{1} C_{0}$ & $\mathrm{~T}_{1} R_{0} C_{1}$ \\
\hline Constant & $1208.453^{* *}$ & 581.684 & -524.420 & -3553.204 & 714.384 & -1457.527 \\
& $(474.151)$ & $(603.815)$ & $(6767.380)$ & $(3427.986)$ & $(1479.981)$ & $(1649.474)$ \\
Region & Yes & Yes & Yes & Yes & Yes & Yes \\
\hline Observations & 2051 & 2535 & 104 & 180 & 230 & 336 \\
\hline \hline
\end{tabular}

Note: T, R and C refer to minimum tillage, crop residue retention and cereal-legume intercropping. The subscripts ' 0 ' and ' 1 ' denote use and non use, respectively. Standard errors in parentheses.

${ }^{*} p<0.10,{ }^{* *} p<0.05,{ }^{* * *} p<0.01$. 
Table A.1o: Estimates of risk of crop failure equations

\begin{tabular}{|c|c|c|c|c|c|c|}
\hline & $\mathrm{T}_{0} R_{0} C_{0}$ & $\mathrm{~T}_{1} R_{0} C_{0}$ & $\mathrm{~T}_{0} R_{1} C_{0}$ & $\mathrm{~T}_{0} R_{0} C_{1}$ & $\mathrm{~T}_{1} R_{1} C_{0}$ & $\mathrm{~T}_{1} R_{0} \mathrm{C}_{1}$ \\
\hline Household size & $\begin{array}{l}-0.014 \\
(0.015)\end{array}$ & $\begin{array}{c}-0.040^{* * *} \\
(0.014)\end{array}$ & $\begin{array}{l}-0.044 \\
(0.094)\end{array}$ & $\begin{array}{c}0.042 \\
(0.085)\end{array}$ & $\begin{array}{c}0.014 \\
(0.048)\end{array}$ & $\begin{array}{c}0.005 \\
(0.037)\end{array}$ \\
\hline Male headed & $\begin{array}{c}0.113 \\
(0.094)\end{array}$ & $\begin{array}{c}0.104 \\
(0.113)\end{array}$ & $\begin{array}{l}-0.024 \\
(0.123)\end{array}$ & $\begin{array}{l}-0.391 \\
(0.309)\end{array}$ & $\begin{array}{l}-0.024 \\
(0.234)\end{array}$ & $\begin{array}{l}-0.027 \\
(0.221)\end{array}$ \\
\hline Age of head & $\begin{array}{c}0.003 \\
(0.003)\end{array}$ & $\begin{array}{l}-0.003 \\
(0.003)\end{array}$ & $\begin{array}{l}-0.029 \\
(0.034)\end{array}$ & $\begin{array}{l}-0.001 \\
(0.008)\end{array}$ & $\begin{array}{l}-0.009 \\
(0.011)\end{array}$ & $\begin{array}{c}0.001 \\
(0.007)\end{array}$ \\
\hline Head education & $\begin{array}{l}-0.054 \\
(0.053)\end{array}$ & $\begin{array}{c}0.005 \\
(0.047)\end{array}$ & $\begin{array}{l}-0.118 \\
(0.239)\end{array}$ & $\begin{array}{l}0.275^{*} \\
(0.159)\end{array}$ & $\begin{array}{l}-0.119 \\
(0.232)\end{array}$ & $\begin{array}{l}-0.003 \\
(0.135)\end{array}$ \\
\hline Agricultural asset wealth & $\begin{array}{c}0.010 \\
(0.018)\end{array}$ & $\begin{array}{c}0.017 \\
(0.015)\end{array}$ & $\begin{array}{c}0.071 \\
(0.119)\end{array}$ & $\begin{array}{c}0.033 \\
(0.040)\end{array}$ & $\begin{array}{c}0.046 \\
(0.064)\end{array}$ & $\begin{array}{l}-0.043 \\
(0.038)\end{array}$ \\
\hline Credit access & $\begin{array}{l}0.063^{*} \\
(0.032)\end{array}$ & $\begin{array}{c}0.141^{* * * *} \\
(0.034)\end{array}$ & $\begin{array}{c}0.016 \\
(0.267)\end{array}$ & $\begin{array}{c}0.193 \\
(0.156)\end{array}$ & $\begin{array}{l}-0.170 \\
(0.123)\end{array}$ & $\begin{array}{l}-0.156^{*} \\
(0.088)\end{array}$ \\
\hline Livestock holdings (log) & $\begin{array}{l}-0.005 \\
(0.008)\end{array}$ & $\begin{array}{c}0.005 \\
(0.008)\end{array}$ & $\begin{array}{l}-0.022 \\
(0.041)\end{array}$ & $\begin{array}{c}0.011 \\
(0.027)\end{array}$ & $\begin{array}{c}0.017 \\
(0.033)\end{array}$ & $\begin{array}{c}0.038 \\
(0.026)\end{array}$ \\
\hline Land size (log) & $\begin{array}{l}-0.008 \\
(0.023)\end{array}$ & $\begin{array}{c}0.001 \\
(0.021)\end{array}$ & $\begin{array}{c}0.100 \\
(0.157)\end{array}$ & $\begin{array}{l}0.218^{* *} \\
(0.098)\end{array}$ & $\begin{array}{c}0.014 \\
(0.082)\end{array}$ & $\begin{array}{c}0.021 \\
(0.066)\end{array}$ \\
\hline Distance to road & $\begin{array}{c}0.002^{* * *} \\
(0.001)\end{array}$ & $\begin{array}{l}0.001^{* *} \\
(0.001)\end{array}$ & $\begin{array}{c}0.004 \\
(0.008)\end{array}$ & $\begin{array}{l}-0.004 \\
(0.003)\end{array}$ & $\begin{array}{c}0.003 \\
(0.002)\end{array}$ & $\begin{array}{l}-0.001 \\
(0.002)\end{array}$ \\
\hline Distance to market & $\begin{array}{c}-0.001^{* * *} \\
(0.000)\end{array}$ & $\begin{array}{l}-0.000 \\
(0.000)\end{array}$ & $\begin{array}{l}-0.002 \\
(0.001)\end{array}$ & $\begin{array}{c}0.000 \\
(0.001)\end{array}$ & $\begin{array}{l}-0.001 \\
(0.001)\end{array}$ & $\begin{array}{l}0.001 * \\
\text { (0.001) }\end{array}$ \\
\hline No soil nutrient constraint & $\begin{array}{l}-0.030 \\
(0.030)\end{array}$ & $\begin{array}{c}-0.100^{* * *} \\
(0.027)\end{array}$ & $\begin{array}{l}-0.006 \\
(0.167)\end{array}$ & $\begin{array}{c}0.015 \\
(0.087)\end{array}$ & $\begin{array}{c}0.015 \\
(0.094)\end{array}$ & $\begin{array}{l}0.111^{* *} \\
(0.055)\end{array}$ \\
\hline Good quality soil plots & $\begin{array}{l}-0.006 \\
(0.010)\end{array}$ & $\begin{array}{c}0.001 \\
(0.009)\end{array}$ & $\begin{array}{c}0.068 \\
(0.075)\end{array}$ & $\begin{array}{l}-0.003 \\
(0.027)\end{array}$ & $\begin{array}{l}-0.021 \\
(0.044)\end{array}$ & $\begin{array}{c}0.002 \\
(0.019)\end{array}$ \\
\hline Poor soil quality plots & $\begin{array}{l}-0.021^{*} \\
(0.012)\end{array}$ & $\begin{array}{c}0.003 \\
(0.009)\end{array}$ & $\begin{array}{c}0.008 \\
(0.069)\end{array}$ & $\begin{array}{c}0.054 \\
(0.034)\end{array}$ & $\begin{array}{l}-0.012 \\
(0.059)\end{array}$ & $\begin{array}{c}0.018 \\
(0.021)\end{array}$ \\
\hline Organic fertilizer & $\begin{array}{l}-0.017 \\
(0.041)\end{array}$ & $\begin{array}{c}0.044 \\
(0.039)\end{array}$ & $\begin{array}{c}0.131 \\
(0.226)\end{array}$ & $\begin{array}{l}-0.042 \\
(0.116)\end{array}$ & $\begin{array}{l}-0.139 \\
(0.152)\end{array}$ & $\begin{array}{l}-0.067 \\
(0.086)\end{array}$ \\
\hline Price rise of farm inputs & $\begin{array}{l}0.086^{* *} \\
(0.035)\end{array}$ & $\begin{array}{c}0.093^{* * *} \\
(0.036)\end{array}$ & $\begin{array}{l}-0.210 \\
(0.268)\end{array}$ & $\begin{array}{c}0.074 \\
(0.151)\end{array}$ & $\begin{array}{c}0.080 \\
(0.133)\end{array}$ & $\begin{array}{l}-0.044 \\
(0.089)\end{array}$ \\
\hline Mean temperature & $\begin{array}{c}0.003 \\
(0.005)\end{array}$ & $\begin{array}{c}0.003 \\
(0.004)\end{array}$ & $\begin{array}{c}0.034 \\
(0.028)\end{array}$ & $\begin{array}{c}0.026 \\
(0.031)\end{array}$ & $\begin{array}{c}0.014 \\
(0.011)\end{array}$ & $\begin{array}{l}-0.004 \\
(0.013)\end{array}$ \\
\hline Rainfall previous year & $\begin{array}{c}0.000 \\
(0.000)\end{array}$ & $\begin{array}{c}0.000 \\
(0.000)\end{array}$ & $\begin{array}{l}-0.001 \\
(0.002)\end{array}$ & $\begin{array}{c}0.001 \\
(0.001)\end{array}$ & $\begin{array}{c}0.000 \\
(0.001)\end{array}$ & $\begin{array}{c}0.001 \\
(0.001)\end{array}$ \\
\hline Average rainfall & $\begin{array}{c}0.000 \\
(0.000)\end{array}$ & $\begin{array}{c}0.000 \\
(0.000)\end{array}$ & $\begin{array}{l}-0.000 \\
(0.002)\end{array}$ & $\begin{array}{l}-0.003 \\
(0.002)\end{array}$ & $\begin{array}{l}-0.000 \\
(0.001)\end{array}$ & $\begin{array}{l}-0.000 \\
(0.001)\end{array}$ \\
\hline Standard deviation of rainfall & $\begin{array}{c}0.000 \\
(0.001)\end{array}$ & $\begin{array}{l}-0.000 \\
(0.000)\end{array}$ & $\begin{array}{l}-0.000 \\
(0.004)\end{array}$ & $\begin{array}{c}0.000 \\
(0.003)\end{array}$ & $\begin{array}{l}-0.001 \\
(0.002)\end{array}$ & $\begin{array}{c}0.001 \\
(0.001)\end{array}$ \\
\hline Mundlak variables & 19.22 & $39.18^{* * *}$ & 6.49 & 14.27 & 6.26 & 12.17 \\
\hline Year $(=2015 / 16)$ & $\begin{array}{c}0.071 \\
(0.063)\end{array}$ & $\begin{array}{l}0.120^{*} \\
(0.067)\end{array}$ & $\begin{array}{c}0.301 \\
(1.174)\end{array}$ & $\begin{array}{l}0.586^{*} \\
(0.301)\end{array}$ & $\begin{array}{c}0.469 \\
(0.540)\end{array}$ & $\begin{array}{c}0.307 \\
(0.191)\end{array}$ \\
\hline IMR & $\begin{array}{c}0.129 \\
(0.123)\end{array}$ & $\begin{array}{c}0.418^{* * *} \\
(0.138)\end{array}$ & $\begin{array}{c}0.000 \\
(0.577)\end{array}$ & $\begin{array}{l}0.918^{* *} \\
(0.459)\end{array}$ & $\begin{array}{l}-0.051 \\
(0.277)\end{array}$ & $\begin{array}{c}0.238 \\
(0.196)\end{array}$ \\
\hline IMR X Year & $\begin{array}{l}0.134^{* *} \\
(0.065)\end{array}$ & $\begin{array}{l}-0.096 \\
(0.067)\end{array}$ & $\begin{array}{l}-0.007 \\
(0.451)\end{array}$ & $\begin{array}{l}-0.143 \\
(0.143)\end{array}$ & $\begin{array}{l}-0.236 \\
(0.239)\end{array}$ & $\begin{array}{r}-0.066 \\
(0.100)\end{array}$ \\
\hline \multicolumn{7}{|c|}{ (table continued on next page) } \\
\hline
\end{tabular}


Table A.1o ... continued

\begin{tabular}{lcccccc}
\hline \hline & $\mathrm{T}_{0} R_{0} C_{0}$ & $\mathrm{~T}_{1} R_{0} C_{0}$ & $\mathrm{~T}_{0} R_{1} C_{0}$ & $\mathrm{~T}_{0} R_{0} C_{1}$ & $\mathrm{~T}_{1} R_{1} C_{0}$ & $\mathrm{~T}_{1} R_{0} C_{1}$ \\
\hline Constant & $0.719^{* * *}$ & 0.218 & 0.060 & -1.645 & 0.959 & 0.106 \\
& $(0.125)$ & $(0.210)$ & $(1.910)$ & $(1.943)$ & $(0.762)$ & $(0.702)$ \\
Region & Yes & Yes & Yes & Yes & Yes & Yes \\
\hline Observations & 2052 & 2529 & 104 & 180 & 229 & 336 \\
\hline \hline
\end{tabular}

Note: $\mathrm{T}, \mathrm{R}$ and $\mathrm{C}$ refer to minimum tillage, crop residue retention and cereal-legume intercropping. The subscripts ' $o$ ' and ' 1 ' denote use and non use, respectively. parentheses. Standard errors in ${ }^{*} p<0.10,{ }^{* *} p<0.05,{ }^{* * *} p<0.01$. 
Table A.11: Test on validity of the exclusion restrictions

\begin{tabular}{|c|c|c|c|c|c|}
\hline & Head count & Poverty gap & Poverty severity & Crop income & Cost of production \\
\hline \multirow[t]{2}{*}{ Household size } & $0.084^{* * *}$ & $0.036^{* * *}$ & $0.018^{* * *}$ & -204.738 & $167.740^{* *}$ \\
\hline & (о.016) & $(0.007)$ & (0.004) & $(401.383)$ & $(65.221)$ \\
\hline \multirow[t]{2}{*}{ Male headed } & -0.016 & -0.025 & -0.026 & -842.380 & $244 \cdot 457$ \\
\hline & (0.091) & $(0.036)$ & $(0.020)$ & (2098.199) & $(351.834)$ \\
\hline \multirow[t]{2}{*}{ Age of head } & -0.004 & -0.002 & -0.001 & -31.352 & -3.315 \\
\hline & $(0.003)$ & (0.001) & (o.001) & $(71.641)$ & $(12.083)$ \\
\hline \multirow[t]{2}{*}{ Head education } & -0.024 & -0.017 & -0.007 & 196.112 & 108.007 \\
\hline & $(0.050)$ & (o.019) & (0.011) & $(1280.250)$ & $(183.802)$ \\
\hline \multirow[t]{2}{*}{ Agricultural asset wealth } & -0.015 & 0.001 & 0.002 & $1074.997^{* * *}$ & -25.573 \\
\hline & (o.017) & (o.007) & (0.004) & (390.275) & $(67.554)$ \\
\hline \multirow{2}{*}{ Credit access } & 0.010 & 0.006 & 0.006 & $-647 \cdot 760$ & -5.699 \\
\hline & $(0.042)$ & (0.016) & (o.009) & $(843.075)$ & $(101.707)$ \\
\hline \multirow[t]{2}{*}{ Livestock holdings (log) } & -0.001 & -0.000 & -0.001 & 56.411 & -45.110 \\
\hline & (o.007) & (0.003) & $(0.002)$ & $(203.782)$ & $(41.087)$ \\
\hline \multirow[t]{2}{*}{ Land size (log) } & 0.007 & 0.000 & 0.000 & $-2499.535^{* * *}$ & $-375.621^{* * *}$ \\
\hline & (0.015) & (o.0o6) & (o.003) & $(549 \cdot 507)$ & $(94 \cdot 438)$ \\
\hline \multirow[t]{2}{*}{ Distance to road } & -0.001 & $-0.000^{* *}$ & $-0.000^{* * *}$ & $-48.019^{* * *}$ & -3.832 \\
\hline & (o.001) & (о.оoo) & (o.ooo) & $(13.334)$ & $(2.448)$ \\
\hline \multirow[t]{2}{*}{ Distance to market } & $0.001^{* * *}$ & $0.001^{* * *}$ & $0.000^{* * *}$ & $24.010^{* *}$ & $-4.700^{* * *}$ \\
\hline & (o.ooo) & (o.ooo) & (o.ooo) & $(10.306)$ & $(1.610)$ \\
\hline \multirow[t]{2}{*}{ No soil nutrient constraint } & $-0.073^{* * *}$ & $-0.019^{*}$ & -0.010 & $-1580.940^{*}$ & 116.820 \\
\hline & $(0.026)$ & $(0.011)$ & (0.007) & $(831.162)$ & $(143.607)$ \\
\hline \multirow[t]{2}{*}{ Good quality soil plots } & 0.007 & 0.003 & 0.002 & 23.874 & 54.957 \\
\hline & (o.010) & (0.004) & (0.002) & $(190.418)$ & $(37.039)$ \\
\hline \multirow[t]{2}{*}{ Poor soil quality plots } & 0.012 & 0.001 & 0.001 & 368.120 & -27.896 \\
\hline & (0.015) & (0.005) & (0.003) & $(243.071)$ & $(39.787)$ \\
\hline \multirow[t]{2}{*}{ Organic fertilizer } & $0.116^{* *}$ & 0.029 & 0.013 & $1981.593^{*}$ & $-313.412^{*}$ \\
\hline & (0.046) & (o.019) & (0.011) & $(1099.641)$ & (188.113) \\
\hline \multirow[t]{2}{*}{ Price rise of farm inputs } & -0.025 & -0.015 & -0.009 & $-2735 \cdot 777^{* * *}$ & -58.817 \\
\hline & (o.045) & (0.017) & (0.010) & (969.425) & $(140.826)$ \\
\hline \multirow[t]{2}{*}{ Mean temperature } & $0.013^{* * *}$ & $0.003^{*}$ & $0.002^{*}$ & 114.359 & $-72.681^{* * *}$ \\
\hline & (0.005) & (0.002) & (0.001) & (150.997) & $(23 \cdot 311)$ \\
\hline \multirow[t]{2}{*}{ Rainfall previous year } & $0.000^{*}$ & 0.000 & -0.000 & 5.276 & -0.712 \\
\hline & (o.ooo) & (o.ooo) & (o.ooo) & $(4.947)$ & (o.745) \\
\hline \multirow[t]{2}{*}{ Average rainfall } & $-0.001^{* * *}$ & $-0.001^{* * *}$ & $-0.000^{* * *}$ & $-22.090^{* * * *}$ & 1.173 \\
\hline & (o.ooo) & (o.ooo) & (o.ooo) & (8.199) & $(1.132)$ \\
\hline \multirow[t]{2}{*}{ Std. dev. of rainfall } & -0.000 & 0.000 & 0.000 & $23.953^{* *}$ & -1.483 \\
\hline & (o.ooo) & (o.ooo) & (o.ooo) & (11.159) & $(1.818)$ \\
\hline \multirow[t]{2}{*}{ Advice on crop production } & -0.003 & 0.001 & -0.001 & 250.037 & $24 \cdot 524$ \\
\hline & (o.041) & (о.018) & (0.010) & $(1009.637)$ & $(131.756)$ \\
\hline \multirow[t]{2}{*}{ Advice on NRM } & 0.046 & 0.008 & 0.004 & $-615 \cdot 375$ & $-27 \cdot 581$ \\
\hline & $(0.042)$ & (o.019) & (o.011) & (1174.043) & (155.809) \\
\hline Mundlak variables & Yes & Yes & Yes & Yes & Yes \\
\hline Region & Yes & Yes & Yes & Yes & Yes \\
\hline Year $(=2015 / 16)$ & -0.021 & -0.004 & 0.000 & 1891.546 & $1113.972^{* * *}$ \\
\hline
\end{tabular}


APPENDIX

Table A.11 ...continued

\begin{tabular}{|c|c|c|c|c|c|}
\hline & Poverty headcount & Poverty gap & Poverty severity & Crop income & Cost of prod. \\
\hline \multirow{3}{*}{ IMR } & $(0.047)$ & (о.о18) & (о.010) & $(1549.767)$ & $(245 \cdot 520)$ \\
\hline & $-0.464^{* * * *}$ & $-0.137^{* * *}$ & $-0.066^{* *}$ & $-1.03 \mathrm{e}+04^{* *}$ & $1808.240^{* * *}$ \\
\hline & (0.115) & $(0.046)$ & $(0.027)$ & $(4151.258)$ & $(621.299)$ \\
\hline \multirow[t]{2}{*}{ IMR X Year } & 0.039 & 0.008 & 0.003 & $-4855.596^{* * *}$ & $-732.104^{* * *}$ \\
\hline & $(0.056)$ & (0.023) & (0.013) & $(1471.708)$ & $(236.425)$ \\
\hline \multirow[t]{2}{*}{ Constant } & -0.162 & $-0.160^{* * *}$ & $-0.108^{* * *}$ & -4470.747 & $1336.137^{* * *}$ \\
\hline & (0.116) & (0.047) & (0.027) & $(3118.216)$ & $(495.460)$ \\
\hline Observations & 2,661 & 2,661 & 2,661 & 1,947 & 2,051 \\
\hline
\end{tabular}

Note: Bootstrapped standard errors in parentheses

${ }^{*} p<0.10,{ }^{* *} p<0.05,{ }^{* * *} p<0.01$

Table A.12: Impact of CA on poverty headcount, gap and severity

\begin{tabular}{|c|c|c|c|c|c|c|c|c|c|}
\hline \multirow{2}{*}{$\begin{array}{l}\text { CA } \\
\text { set }\end{array}$} & \multicolumn{3}{|c|}{ Headcount } & \multicolumn{3}{|c|}{ Poverty gap } & \multicolumn{3}{|c|}{ Poverty severity } \\
\hline & A & $\mathrm{C}$ & ATT (A-C) & A & C & $\operatorname{ATT}(\mathrm{A}-\mathrm{C})$ & A & C & ATT(A-C) \\
\hline$T_{1} R_{0} C_{0}$ & 0.436 & 0.440 & -0.004 & 0.149 & 0.154 & $-0.005^{*}$ & 0.069 & 0.075 & $-0.005^{* * *}$ \\
\hline$T_{0} R_{1} C_{0} / T_{0} R_{1} C_{1}$ & 0.517 & 0.328 & $0.189^{* *}$ & 0.206 & 0.106 & $0.099^{* * *}$ & 0.103 & 0.039 & $0.065^{* * *}$ \\
\hline$T_{0} R_{0} C_{1}$ & 0.533 & 0.603 & -0.070 & 0.192 & 0.233 & $-0.041^{*}$ & 0.097 & 0.124 & $-0.027^{*}$ \\
\hline$T_{1} R_{1} C_{0} / T_{1} R_{1} C_{1}$ & 0.494 & 0.413 & $0.081^{* * *}$ & 0.172 & 0.138 & $0.033^{* * *}$ & 0.080 & 0.058 & $0.022^{* * *}$ \\
\hline$T_{1} R_{0} C_{1}$ & 0.580 & 0.784 & $-0.203^{* * *}$ & 0.237 & 0.335 & $-0.098^{* * *}$ & 0.125 & 0.176 & $-0.050^{* * *}$ \\
\hline
\end{tabular}

Note: $\mathrm{T}, \mathrm{R}$ and $\mathrm{C}$ refer to Minimum tillage, crop residue retention and cereal-legume intercropping respectively. The subscripts ' $O$ ' and ' 1 ' denote use and non use, respectively. We report actual outcome with CA (A), counterfactual outcome without CA scenario (C) and difference in actual outcome and counterfactual outcome as impact (ATT). Standard errors are not reported to save space. ${ }^{*} p<0.10$, ${ }^{* *} p<0.05,{ }^{* * *} p<0.01$. 
Table A.13: Distributional effects of CA on poverty incidence (headcount) by rainfall and household wealth

\begin{tabular}{|c|c|c|c|c|c|c|}
\hline \multirow{2}{*}{$\begin{array}{l}\text { CA } \\
\text { set }\end{array}$} & \multicolumn{2}{|c|}{ Rainfall shock } & \multicolumn{2}{|c|}{ Livestock holding } & \multicolumn{2}{|c|}{ Land holding } \\
\hline & shortage & surplus & poor & better-off & poor & better-off \\
\hline$T_{1} R_{0} C_{0}$ & $-0.022^{* * *}$ & 0.012 & -0.013 & 0.003 & 0.001 & 0.008 \\
\hline$T_{0} R_{1} C_{0} / T_{0} R_{1} C_{1}$ & 0.147 & $0.264^{*}$ & 0.077 & $0.230^{* *}$ & 0.136 & $0.230^{* * *}$ \\
\hline$T_{0} R_{0} C_{1}$ & -0.065 & -0.078 & $-0.105^{*}$ & $-0.085^{* *}$ & $-0.193^{*}$ & 0.045 \\
\hline$T_{1} R_{1} C_{0} / T_{1} R_{1} C_{1}$ & 0.043 & $0.185^{* * *}$ & 0.018 & $0.115^{* * *}$ & 0.063 & $0.094^{* * *}$ \\
\hline$T_{1} R_{0} C_{1}$ & $-0.205^{* * *}$ & $-0.197^{* * *}$ & $-0.197^{* * *}$ & $-0.206^{* * *}$ & $-0.282^{* * *}$ & $-0.095^{* * *}$ \\
\hline
\end{tabular}

Note: $\mathrm{T}, \mathrm{R}$ and $\mathrm{C}$ refer to Minimum tillage, crop residue retention and cereal-legume intercropping respectively. The subscripts ' $O$ ' and ' 1 ' denote use and non use, respectively. We report only the ATT (difference in actual outcome and counterfactual outcome) only. Standard errors are not reported to save space. Livestock and land poor are households with livestock holdings (TLU) and land holdings (hectares) in the lowest (first) quartile of the distribution and non-poor are those with livestock holdings and land holdings in the second, third and fourth quartiles; ${ }^{*} p<0.10,{ }^{* *} p<0.05,{ }^{* * *} p<0.01$.

Table A.14: Impact of CA on crop income, production cost and risk of crop failure

\begin{tabular}{|c|c|c|c|c|c|c|c|c|c|}
\hline \multirow{2}{*}{$\begin{array}{l}\text { CA } \\
\text { set }\end{array}$} & \multicolumn{3}{|c|}{ Crop income } & \multicolumn{3}{|c|}{ Production cost } & \multicolumn{3}{|c|}{ Crop failure } \\
\hline & A & C & ATT (A-C) & A & $\mathrm{C}$ & ATT(A-C) & A & C & ATT(A-C) \\
\hline$T_{1} R_{0} C_{0}$ & 7524.60 & 4829.85 & $2694 \cdot 75^{* * *}$ & 803.46 & 1287.72 & $-484 \cdot 26^{* * *}$ & 0.773 & 0.788 & $-0.015^{* * *}$ \\
\hline$T_{0} R_{1} C_{0} / T_{0} R_{1} C_{1}$ & 9297.01 & 8198.18 & 1098.83 & 963.61 & 834.90 & 128.46 & 0.900 & 0.874 & 0.026 \\
\hline$T_{0} R_{0} C_{1}$ & 8962.96 & 9005.80 & -42.84 & 687.18 & 1460.30 & $-773.12^{* * *}$ & 0.894 & 0.909 & -0.015 \\
\hline$T_{1} R_{1} C_{0} / T_{1} R_{1} C_{1}$ & 8914.99 & 7835.11 & $1079.88^{*}$ & 836.75 & 997.90 & $-161.15^{* * *}$ & 0.851 & 0.848 & 0.004 \\
\hline$T_{1} R_{0} C_{1}$ & 6592.56 & 988.32 & $5604.23^{* * *}$ & 683.11 & 1082.01 & $-398.91^{* * *}$ & 0.887 & 0.950 & $-0.063^{* * *}$ \\
\hline
\end{tabular}

Note: $\mathrm{T}, \mathrm{R}$ and $\mathrm{C}$ refer to Minimum tillage, crop residue retention and cereal-legume intercropping respectively. The subscripts ' $O$ ' and ' $I$ ' denote use and non use, respectively. We report actual outcome with CA (A), counterfactual outcome without CA scenario (C) and difference in actual outcome and counterfactual outcome as impact (ATT). Standard errors are not reported to save space. ${ }^{*} p<0.10$, ${ }^{* *} p<0.05,{ }^{* * *} p<0.01$. 


\section{CROP DIVERSITY, WELFARE AND CONSUMPTION SMOOTHING UNDER RISK IN RURAL UGANDA*}

\subsection{INTRODUCTION}

Unpredictable and aberrant weather exposes farm households in developing countries to pervasive production risks with significant repercussions on food production, income and consumption (Dercon, 2004; Di Falco and Chavas, 2009; Gao and Mills, 2018). Climate variability also poses an additional challenge to the food security and adaptive capacity of poor and marginalized households who lack natural and economic assets and are repeatedly exposed to market shocks (Asfaw et al., 2018). Households adopt various strategies to mitigate the negative effects of production and consumption risks arising from climate variability and extremes. The literature illustrates that diversifying economic activities (e.g., crops, income, assets or savings) is an important risk management and consumption smoothing strategy adopted by rural households in an environment characterized by incomplete markets and where social safety nets provide limited support (Fafchamps, 1992; Morduch, 1995; Dercon, 1996; Ellis, 2000; Barrett et al., 2001; Kurosaki and Fafchamps, 2002). Farm households adopt crop diversification as self-insurance against multiple risks affecting their income and consumption especially when they face liquidity, asset and credit constraints and their access to off-farm income is very limited (Dercon, 2002; Khanal and Mishra, 2017).

In the current policy discourse, crop diversification is promoted and preferred over monocropping as evidence from Sub-Saharan Africa (SSA) demonstrates that reliance on mono-cropping contributes to low agricultural productivity and exposes rural households to production and price risks (Teklewold et al., 2013; Benson et al., 2008; Chibwana et al., 2012; Saenz and Thompson, 2017). Crop diversification is deemed as important for increasing agricultural production, enhancing food security, reducing poverty, building resilience against economic and climatic risks, while conserving the ecological biodiversity and aiding sustainable agricultural transformation (FAO, 2012; Massawe et al., 2016; Michler and Josephson, 2017; Lin, 2011; Donfouet et al., 2017). As a climatic risk hedging option, crop diversification can reduce the risk of crop failure, yield variability and can mitigate price risks for poor and marginal farm-

* The chapter is co-authored with Nyasha Tirivayi. 
ing households operating in rain-fed areas (Rosenzweig and Parry, 1994; Imbs and Wacziarg, 2003; Bezabih and Sarr, 2012; Coromaldi et al., 2015). Crop diversification also gained a renewed interest due to the liberalization of agricultural policies and the globalization of agricultural markets (Pellegrini and Tasciotti, 2014).

Since the work of Heady (1952) who propose diversification as an agricultural activity to manage uncertainty, there is growing evidence on the role of crop diversification as an effective farm-level response to climate variability (Bradshaw et al., 2004; Seo and Mendelsohn, 2008; Di Falco and Chavas, 2009; Arslan et al., 2018; Asfaw et al., 2018). Although there are many studies that assess the economics of crop diversification, much of the empirical literature is skewed towards studying its determinants. The literature on the economic impacts of crop diversification can be divided into two strands: (i) studies that focus on the relationship between crop diversity and risk, and (ii) studies that focus on the relationship between crop diversity and household welfare (Michler and Josephson, 2017). While there are numerous seminal studies that have focused on the relationship between diversity and risk (Rosenzweig and Wolpin, 1993; Alderman and Paxson, 1994; Dercon, 1996; Little et al., 2001; Di Falco and Perrings, 2005), the relationship between crop diversity and household welfare remains less studied (Michler and Josephson, 2017; Asfaw et al., 2018). Recent studies in India (Birthal et al., 2015), Thailand (Kasem and Thapa, 2011), and Ethiopia (Michler and Josephson, 2017) show that crop diversification prevents and alleviates poverty, reduces poverty persistence and increases income. Other studies in Africa find that crop diversification increases income and energy intake in Niger (Asfaw et al., 2018), dietary diversity in Malawi (Jones et al., 2014; Snapp and Fisher, 2015) and nutrition for poor farm households in Nigeria (Rahman and Chima, 2016). The evidence on the relationship between crop diversification and risk coping or consumption smoothing responses is thin (Rosenzweig and Wolpin, 1993; Dercon, 1996). Di Falco et al. (2014) is perhaps the only study that shows crop diversification to be a substitute for financial insurance when households mitigate the impact of risk.

This chapter contributes to the literature by providing empirical evidence on the household welfare and risk coping effects of crop diversity using panel data from Uganda. This study differs from existing studies in many aspects. First, most of the existing studies are based on cross-sectional data and estimates are, therefore, plagued by endogeneity. Our study utilizes rich panel data from Uganda which enables us capture the dynamics in crop diversification and its implications on household welfare. Since the survey data is georeferenced, we merge it with historical weather data to generate climate (rainfall) variables. Second, to address the econometric challenges of endogeneity and reverse causality, we employ estimation strategies that rely on panel data econometrics and instrumental variables methods. We exploit the exogenous variation in crop production decisions due to climate variability and neighborhood effects to instrument crop diversity. Third, the level of crop diversity is measured using a series of crop diversity indices (Count, Shannon-Weaver, Composite entropy and 
Berger-Parker) to capture the extent of the diversity of crops cultivated. Hence, we are able to study the different aspects of multi-cropping regimes and assess the sensitivity of results to different crop diversity measures. In addition to assessing the average impacts of crop diversification on consumption, we also estimate the heterogeneous effects using quantile regressions.

We find that crop diversity increases household welfare (dietary diversity and consumption expenditure) and reduces households' reliance on informal insurance as a risk coping mechanism. Results from quantile based instrumental variables regression show that crop diversity generates higher consumption benefits for low consuming households positioned in the lower quantiles of the consumption distribution. The findings suggest that crop diversity contributes to nutrition security, consumption smoothing and risk management among rural households. The evidence will help in the effective design of policies that will facilitate promotion of diversification. Overall, the findings of this study provide useful insights for the current and emerging policy focus on agricultural transformation and economic diversification in rural SSA.

The rest of this chapter is structured as follows. Section 3.2 presents a brief overview of the study country context. Section 3.3 presents a brief theoretical framework. Section 3.4 demonstrates the empirical strategies. Section 3.5 discusses the data and variables used for the analysis. Section 3.6 presents the econometric results and the last section concludes.

\subsection{COUNTRY CONTEXT}

Uganda is a small, landlocked country in Eastern Africa that has achieved significant poverty reduction in the last decade (World Bank, 2016). Much of the national poverty reduction has occurred among households working in agriculture. Agricultural income growth appears to be the major driver for Uganda's progress in poverty reduction. Due to its immense potential in the country's economy, the agricultural sector has been given priority in the national development plan for poverty reduction and economic growth. Despite this political will and significant gains in poverty reduction, a third of Ugandans remain poor, food insecure and vulnerable to shocks. As in much of SSA, poverty and hunger in Uganda are intrinsically linked to agriculture, the sector dominated by smallholder families (estimated at $85 \%$ ) that are engage in mixed crop-livestock farming and primarily grow crops for subsistence purposes. ${ }^{1}$ The major food crops grown in Uganda include maize, rice, beans, soya beans, palms, and horticultural crops. Cash crops include coffee, cotton, tea, cocoa, tobacco, and sugarcane (Veljanoska, 2014).

The choice of Uganda as a case for this study is motivated by the following reasons. First, Uganda is a country facing a wide range of development challenges includ-

I See https://ccafs.cgiar.org/publications/climate-smart-agriculture-ethiopia.XCzUKFxKjcs 
ing low agricultural productivity, high food insecurity, and climate change. Increased weather (rainfall and temperature) variability negatively affect food production, consumption and make farm households net buyers in markets. In response to climatic variability, rural Ugandan households engage in ex-ante and ex-post consumption smoothing strategies. Second, Uganda has diverse and rich agroecological diversity hotspots that are essential for food security, livelihoods and adaptation to changes in food systems in the face of climate change (Smale, 2006; Coromaldi et al., 2015; Covarrubias, 2015). Third, there are few off-farm income diversification options in the country. This limits the capacity of diversifying income away from agriculture as a strategy for poverty reduction.

Given that Ugandan agriculture is mostly rain-fed, relying on few low-risk crops or specialization in few staple crops may exacerbate exposure to shocks and aggravate food insecurity and poverty. Therefore, the decision to engage in diversified crop production comes naturally. Increasing crop diversity appears to be the most promising solution to deal with irregular weather conditions, market shocks and for improving rural livelihoods (Veljanoska, 2014). Uganda is one of the few African countries that explicitly incorporated diversification as part of its national agricultural investment strategies for adaptation and building resilience (Arslan et al., 2018). Therefore, Uganda makes an interesting case to explore the household welfare and risk coping or consumption smoothing effects of crop diversity. The evidence generated from this study will feed into the current agricultural development policy of the country that seeks to achieve food and nutrition security and improve household welfare through enhancing sustainable agricultural productivity.

\section{$3 \cdot 3$ THEORETICAL FRAMEWORK}

\subsubsection{Economics of crop diversification}

Economic theory asserts that households diversify their economic activities to improve their risk management capacity, smooth income streams ex-ante (Alderman and Paxson, 1994; Barrett et al., 2001), and smooth consumption ex-post shocks (Morduch, 1995). Although diversification is a common practice across different sectors (e.g., finance), the peculiarities of agricultural production such as dependence on weather patterns, seasonality in the demand for inputs and heterogeneity in land quality distinguishes diversification in agricultural production from other sectors (Arslan et al., 2018). Incomplete credit and insurance markets or market failures, quasi-universal circumstances in developing countries, are among the primary conditions that lead to diversification in rural economies (Kurosaki and Fafchamps, 2002; Arslan et al., 2018).

Portfolio theory postulates that crop diversification is a production risk management strategy for risk-averse and subsistence farm households (Rosenzweig, 1988). In the absence of insurance and reliable food markets, for instance, poor households 
minimize their exposure to various risks by growing their own food and diversifying their activities (Fafchamps, 1992; Kurosaki and Fafchamps, 2002). By diversifying food crop production, a farm household gains some assurance that it can have something to eat even in the event of crop failure, food price shocks, or lack of food in local markets. When ex-post consumption smoothing mechanisms are absent, diversification can help households meet their risk-management needs left unmet due to missing insurance markets (Binswanger, 1983; Fafchamps, 1992; Reardon, 1997). Depending on their market-orientation, some farm households may also add new crops to their crop mix to increase their income. Crop diversification may also reduce income variability by allowing participation in multiple crop markets. However, the effectiveness depends on the level of correlation of prices in the markets.

The desire for income or profit maximization and risk minimization are not the only stimuli for diversification in agricultural production (e.g., (Omamo, 1998; Pope and Prescott, 1980). Studies demonstrate that diversification in agricultural production can arise under conditions where specialization would be expected or even if we assume no risk (Pope and Prescott, 1980; Just and Pope, 2001). In rural economies where households face multiple market imperfections and markets are poorly developed and less integrated (De Janvry and Sadoulet, 2006), crop diversification decisions may also be motivated by food security and nutritional considerations (Bezabih and Di Falco, 2012; Pellegrini and Tasciotti, 2014; Hoddinott et al., 2015). While markets do not exist in some cases, if they do, accessing them might be prohibitive due to high transaction costs. In other circumstances, there could be a constraint on the quantities to be exchanged in the markets. In the presence of high transaction costs, households are forced to satisfy consumption from own production (Fafchamps, 1992; Van Dusen and Taylor, 2005).

\subsubsection{Linking crop diversity with welfare and risk coping}

The interest in this chapter is to empirically show the effect of crop diversity on household welfare and risk coping behavior related to consumption smoothing. Although the lack of formal insurance and incomplete markets is the major factors driving crop diversification decision, increased crop diversification is expected to affect welfare and risk coping behavior. Following Asfaw et al. (2018) and Michler and Josephson (2017), the link between crop diversification $(D)$ and household welfare $(W)$ could be represented as

$$
W_{i t}=f\left(D_{i t}\left(S_{t-s}, K_{i t}\right), v_{i t}\right)
$$

where $S$ is shock, $t$ and $s$ denote time (with $t \geq s$ ), and $v$ is a vector of unobserved factors. $K$ is a vector of household asset endowments that could have multi-directional effect on crop diversification and welfare (Asfaw et al., 2018). From equation 3.1 and 
following Asfaw et al. (2018), we hypothesize that crop diversification will increase household welfare as

$$
\frac{\partial W}{\partial D}>0
$$

Likewise, we represent the relationship between crop diversification $(D)$ and risk coping $(R)$ as follows

$$
R_{i t}=f\left(D_{i t}\left(S_{t-s}, K_{i t}\right), \epsilon_{i t}\right)
$$

where $D, K$ and $S$ are as defined above, and $\epsilon$ is a vector of unobserved factors. We predict that crop diversification could reduce households' use of less effective risk coping strategies as

$$
\frac{\partial R}{\partial D}<0
$$

\subsubsection{Impact pathways}

This section summarizes, based on empirical evidence, the main potential pathways through which crop diversification would impact household welfare and risk coping (consumption smoothing) behaviour.

\subsubsection{Productivity and income effects}

Crop diversification would affect household welfare (consumption expenditure and diet diversity) through various channels. Primarily, it can improve household welfare through its productivity and income. Crop diversification boosts crop productivity at the household level by increasing yield (Feder et al., 1985; Di Falco and Perrings, 2005; Di Falco et al., 2010; Chavas and Di Falco, 2012). For households that primarily consume from own production, cultivating diverse crops guarantees consumption of diverse diets (Ecker and Qaim, 2011). It can also increase consumption and nutrition diversity through increasing crop income from high-value and cash crops in the production portfolio (Fafchamps, 1992; Birthal et al., 2015). The resulting income would enable a household purchase diverse and potentially micronutrient-rich foods, and ultimately improves household welfare (Dzanku and Sarpong, 2011). For households with poor access to markets, reliance on monocropping for consumption makes their diet poorly diversified that would lead to high risk of micronutrient deficiencies and malnutrition (Ecker and Qaim, 2011). In contrast, crop diversification would exert positive consumption and nutrition effects in areas where markets are less integrated 
with national or local food markets (Fafchamps, 1992; Omamo, 1998; Barrett et al., 2001; Lovo and Veronesi, 2019). Besides its direct effect, crop diversity might affect household welfare indirectly by influencing the local availability of crops in relatively marginalized areas (Ecker and Qaim, 2011).

\subsubsection{Downside risk mitigation and insurance effects}

When environmental risks increase, crop diversification can be a natural insurance (as opposed to financial insurance) against downside risk or crop failure and increases production and food consumption (Baumgärtner and Quaas, 2010). Ecologists have provided two explanations for a beneficial role of crop diversity in production risk management. The "sampling effect" hypothesis asserts that households manage production risks by increasing the number of crops with different climatic requirements and responses to biotic stressors (Tilman et al., 2005). The second set of explanation, the "complementarity effect' hypothesis, emphasizes that growing different crops that have different traits and characteristics is a strategy to adapt to different environmental conditions due to complementarity effects (Sala et al., 2000; Loreau and Hector, 2001). Both effects would ultimately reduce the probability of crop failure (Loreau and Hector, 2001; Chavas and Di Falco, 2012). Crop diversification can also reduce exposure to weather shocks and increase crop yields through controlling crop diseases and pests. It could also reduce exposure to market risks (e.g., fluctuations of grain prices) and help households manage price risks by having crops in the portfolio that exhibit uncorrelated prices (Dercon, 1996). Through its risk buffering benefits, crop diversification can help households improve their welfare and grow out of poverty (Michler and Josephson, 2017).

\subsubsection{Consumption smoothing effects}

Crop diversification can influence risk coping or consumption smoothing behavior of rural households in various ways. In rural areas where formal insurance or safety nets are lacking or not fully functioning, crop diversification can be an effective risk coping strategy (Barrett et al., 2001; Dercon, 2002; Loison, 2015). Acting as a substitute to formal insurance (Di Falco et al., 2014), crop diversity could reduce households' use of negative risk coping mechanisms. Through increasing food consumption and welfare and hence improved consumption smoothing, crop diversity can reduce the need for informal insurance and involuntary diet changes as risk-coping strategies. The effect of crop diversification on reducing the use of risky consumption smoothing strategies would be higher when households experience shocks vis-à-vis a scenario where the household faces no shocks (Asfaw et al., 2018). 


\subsection{EMPIRICAL STRATEGY}

\subsubsection{Drivers of crop diversification}

Crop choice or diversification decisions will be determined by households' willingness to bear risk or risk attitude, the availability of consumption smoothing measures, and households' preferences (Fafchamps, 1992; Rosenzweig and Wolpin, 1993; Alderman and Paxson, 1994; Arslan et al., 2018; Asfaw et al., 2018). A wide range of variables are introduced in the crop diversity model to capture the degree of risk aversion, transaction costs, and household preferences. The variables include household asset endowments that could determine the degree to which farmers diversify their production portfolio (Arslan et al., 2018; Asfaw et al., 2018). Asset endowments of the household are represented as livelihood assets or capitals and include natural capital (rainfall, temperature, elevation, cultivated land, agroecology), physical capital (livestock holding, asset value), human capital (education, gender, age of the head, household size), financial capital (remittances and transfers, distance to road, distance to markets), and social capital.

Physical and human capital assets would affect households' ability to bear risk (Feder et al., 1985; Rosenzweig and Wolpin, 1993; Dercon, 1996; Barrett et al., 2001). Consumption preferences are affected by variables such as the demographic composition of the household that shift the taste for consumption goods (Dercon, 1996). Household demographic composition (e.g., household size) and wealth would also affect risk and time preferences as well as liquidity and credit constraints. Proximity to markets and major roads, that would capture the effect of the economic and geographic environment and transaction costs, are important pull factors that would influence diversification behavior, risk coping and household welfare (Barrett et al., 2001). Climate factors are the major exogenous factors that could influence households' production decisions through altering risk profile (Angrist and Krueger, 2001; Adger et al., 2009; Arslan et al., 2018). They are captured by rainfall, elevation and temperature that are major source of covariate shocks and reflect exposure to weather shocks and the short and long-term temporal and spatial rainfall variations (Asfaw et al., 2018; Gao and Mills, 2018).

The estimates for drivers of crop diversification are obtained using the following correlated random effects (CRE) model

$$
D_{i t}=\delta X_{i t}+\gamma Z_{i t}+\lambda \bar{M}_{i}+\varepsilon_{i t}
$$

where $D_{i t}$ is crop diversity (measured using different crop diversity indices discussed in section 3.5.2), $X_{i t}$ is a vector of the asset endowment or capital variables discussed above; $Z_{i t}$ is a set of instrumental variables (mean temperature and eleva- 
tion, average village level crop diversification, and rainfall shock). We also include region, time and region-time interactions to control for temporal and spatial differences in biophysical conditions, access to infrastructure, policy changes, etc. not possibly captured by the other covariates. ${ }^{2}$ In equation 3.5 , we assume that time-invariant unobserved effect or household-specific heterogeneity (say $c_{i}$ ) can be replaced with its projection onto the time averages of the exogenous variables $\left(\bar{M}_{i}\right)$ as: $c_{i}=\lambda \bar{M}_{i}+a_{i}$. $\varepsilon_{i t}$ is the idiosyncratic error term that captures time-varying unobserved factors. $\delta$ and $\gamma$ are the parameters of interest to be estimated.

The CRE is an alternative approach to the fixed effects (Mundlak, 1978; Chamberlain, 1982). It is preferred over the traditional random effects (RE) model as it relaxes the stringent exogeneity assumption of the RE approach by allowing an arbitrary correlation between the unobserved effect $\left(c_{i}\right)$ and the explanatory variables $\left(X_{i t}\right.$ and $\left.Z_{i t}\right)$. It also avoids the incidental parameters problems associated with the fixed effects. The estimation procedure in CRE amounts to including the mean of all time-varying variables as an additional set of explanatory variables in the crop diversification equation to control for time-invariant unobserved heterogeneity (Wooldridge, 2002, 2010). We run separate regressions for the different crop diversity metrics. ${ }^{3}$

\subsubsection{Strategies for estimating the impact of crop diversification}

Estimating the impact of crop diversity on the outcomes faces numerous econometric issues that could result in endogeneity. The first potential source of endogeneity is the presence of unobserved heterogeneity due to time-invariant factors that would affect both cropping decisions and the outcomes. Crop diversification is a voluntary decision that might be affected by unobserved household characteristics such as preferences, skills, innate ability, and entrepreneurial motives that could lead to selection bias in the choice to diversify or not and also correlated with the outcomes. The second source of endogeneity are time-varying unobserved factors and idiosyncratic shocks that would simultaneously influence crop diversity as well as household welfare and consumption smoothing. Such type of unobserved endogeneity may arise due to omission of relevant time-varying factors, simultaneous responses to idiosyncratic or covariate shocks, or measurement errors (Terza et al., 2008; Verkaart et al., 2017). The third source of endogeneity is reverse causality or simultaneity problem in that household welfare may affect crop diversity and vice versa (Michler and Joseph-

2 In Uganda in particular, there is regional heterogeneity in cropping seasons (rainy) and land quality. While the majority of the country is exposed to two cropping and rainy seasons, the North part benefits from only one rainy season. The central-southern region is the most productive in terms of crop production (Veljanoska, 2014).

3 The crop count index is a count variable that takes a limited number of values. This suggests the use of Poisson regression or other count outcome data models. The other crop diversity indices could also be left-censored. They can be estimated using Tobit or fractional logit as applied to panel data. However, in our sample, the number of left-censored observations is less than $2 \%$. We, therefore, apply linear models. 
son, 2017; Asfaw et al., 2018). Availability of risk coping mechanisms may also determine the need for ex-ante risk management strategies such as crop diversification (Rosenzweig and Wolpin, 1993; Dercon, 1996). Failure to control for these econometric issues will either overestimate or underestimate the supposed true effect of crop diversification. In what follows, we discuss the empirical strategies used to estimate the impact of crop diversity on the outcomes while addressing these econometrics challenges.

\subsubsection{Crop diversity and household welfare}

The relationship between household welafre and crop diversity is represented using the following model

$$
y_{i t}=\phi D_{i t}+\beta X_{i t}+\alpha_{i}+v_{i t}
$$

where $y_{i t}$ is a measure of household welfare (dietary diversity, per adult equivalent consumption expenditure) or risk coping (informal insurance, involuntary change in diets), $D_{i t}$ is crop diversification as defined above and $X_{i t}$ is a vector of additional control variables defined above. $\alpha_{i}$ is the household-specific unobserved effect and $v_{i t}$ is the idiosyncratic error term. $\phi$ is the parameter of interest that denotes the impact of crop diversification on welfare. We utilize fixed effects instrumental variables (FE-IV) approach to estimate the impact of crop diversification on household dietary diversity and per adult equivalent consumption expenditure while addressing endogeneity.

Two sets of instruments are used for household level crop diversification. The first is the average village level crop diversification excluding the household's own crop diversification. The choice of this instrument is inspired by insights from research on the importance of social networks and neighborhood effects in agricultural technology adoption and production decisions (Conley and Udry, 2010; Krishnan and Patnam, 2013; Magnan et al., 2015; Verkaart et al., 2017). Farming decisions of households (including their crop choice) are very likely to be influenced by the decision of neighboring households due to potential learning externality. Farms that operate in the same agro-environmental conditions, and face similar demographic, institutional and economic characteristics, are likely to adopt similar production systems. A farm household located in a village where farmers diversify their crop production is more likely to adopt a diversified production system than a household located in a less diversified village (Ahmadzai, 2017).

The second set of instruments for crop production diversity includes climate variables (Dillon et al., 2015; Hirvonen and Hoddinott, 2017). Climate variability is a major source of risk that alters farmers' risk profile that in turn affects crop portfolio selection (Rosenzweig and Wolpin, 1993; Dercon, 1996; Dercon and Christiaensen, 2011). 
Households' exposure to weather shocks would affect crop diversity. Based on a historical rainfall data which spans about 30 years (1981-2010), we generate a rainfall shock variable as rainfall deviation from the long-term historical average following Michler et al. (2018). The variable could be a proxy for village level climatic conditions and used as instrument to crop production diversity. Variation in temperature also determines farmers' crop choice as different crops respond differently to change in temperature (Dillon et al., 2015; Hirvonen and Hoddinott, 2017). The impact of temperature on production choices varies with elevation. Thus, we exploit the interaction of elevation with temperature as an additional instrument for crop diversity.

The use of the FE-IV is with an assumption that the data generating process for crop diversification and the welfare outcomes is linear. The empirical strategy accounts for endogeneity of crop diversification as well as unobserved heterogeneity. The inclusion of household fixed effects will enable controlling for potential omitted variable bias related to time-invariant unobservables that will affect both crop diversification and the outcomes. The estimator removes the time-invariant unobserved effects by deviating the variables from their time averages, and then applies IV. We report cluster robust standard errors to deal with heteroscedasticity and serial dependence of idiosyncratic shocks. To assess whether our results are robust to the way in which crop diversity is measured, we run separate regressions for each crop diversity index. The outcome equations are also estimated separately for the different outcome measures.

As robustness check, we employ two-stage residual inclusion (2SRI) approach (Terza et al., 2008; Wooldridge, 2014). ${ }^{4}$ The 2SRI approach addresses potential endogeneity and reverse causality between crop diversity and household welfare outcomes. In an application similar to ours, Bezu et al. (2014), Michler and Josephson (2017), and Verkaart et al. (2017) utilize a two-stage predictor substitution (2SPS) method where the unconditional expected values of the endogenous regressor are used as instrument for observed values. The 2SPS is argued to be inconsistent for both the structural parameters and average partial (or marginal) effects while the 2SRI is consistent (Terza et al., 2008). In the 2SRI framework, the first stage involves regressing crop diversification on the instrumental variables and additional covariates. In our case, this first stage is obtained by means of a panel correlated random effects approach discussed above (equation 3.5). From the first stage regressions, we retrieve the residuals that are used in the second stage regression.

The second stage estimation is also implemented using the CRE approach. In the second stage, the endogenous term $\left(D_{i t}\right)$ is maintained in the main outcome equation and the residuals from the first-stage regression are introduced as substitutes for the unobserved confounders. The resulting 2SRI specification is

4 Additional robustness check is also performed using alternative specifications treating crop diversity as exogenous. Moreover, we consider estimations based on balanced sample for the welfare and risk coping outcomes (See tables B.13 and B.14 in Appendix B). 


$$
y_{i t}=\phi D_{i t}+\psi \check{D}_{i t}+\beta X_{i t}+\omega \bar{V}_{i}+\epsilon_{i t}^{2 S R I}
$$

where $y_{i t}$ is a measure of household welfare or risk coping and $D_{i t}$ is crop diversity as discussed above. $\check{D}_{i t}$ includes the residuals of the crop diversification equations which corrects for potential endogeneity between the outcomes and the diversification variable. $X_{i t}$ is as defined above and $\bar{V}_{i}$ is the time-average of all time-varying variables included in the outcome equation. Since the second stage outcome equations include estimates from the first stage reduced form equations (residuals), standard errors are bootstrapped. Due to the short nature of our panel and to control for serial correlation and heteroscedasticity, we estimate panel-robust standard errors with cluster correction at the household level (White, 1980; Cameron and Trivedi, 2010). Results from the FE-IV are also contrasted with various specifications for the two welfare metrics.

\subsubsection{Heterogeneous effects of crop diversity}

Crop diversification can produce impacts that are heterogeneous across the different classes of the consumption distribution and hence can generate non-linear and distributional effects on household welfare (Asfaw et al., 2018). Estimating the distributional effects is important for policy targeting purposes as low-consuming households may be especially responsive to crop diversity relative to high-consuming households. To explore the relationship between crop diversity and consumption at different points in the conditional distribution of consumption expenditure, we model the quantiles of the conditional distribution of aggregate consumption expenditure (per adult equivalent) as a function of crop diversification and other covariates using a quantile-IV regression. ${ }^{5}$

We specify the quantile regression model as follows:

$$
y_{i t, \tau}=\beta_{\tau} d_{i t}+\rho_{\tau} x_{i t}+e_{\tau i t}
$$

with

$$
Q_{\tau}\left(y_{i t} \mid d_{i t}, x_{i t}\right)=\beta_{\tau} d_{i t}+\rho_{\tau} x_{i t}
$$

where $y$ is consumption expenditure, $d$ is crop diversity, $x$ are the other covariates as defined earlier and $e$ is a vector of idiosyncratic errors. $Q_{\tau}\left(y_{i t} \mid d_{i t}, x_{i t}\right)$ identifies the $\tau^{\text {th }}$ conditional quantile of $y$ given $d$ and $x . \rho$ and $\beta$ are vectors of parameters to be estimated.

5 We utilize the Stata command bsqreg to estimate the model that allows us produce QR estimates for several values of $\tau(0.2,0.4,0.6$ and 0.8$)$. The choice of the quantile bandwidths is arbitrary. To allow comparison of estimates from our model with previous findings, we chose same bandwidths as Asfaw et al. (2018). 
Estimating the distribution impact of crop diversity on consumption expenditure is also complicated by potential endogeneity due to reverse causality between the welfare outcome and the crop diversification variables. To deal with this issue, we utilize the two-stage residual inclusion (2SRI) approach discussed above and employed in related studies (Asfaw et al., 2018; Michler et al., 2018). In the first stage, we regress crop diversification on the set of instrumental variables and additional covariates by a means of a panel correlated random effects model discussed earlier. In the second stage, we estimate a pooled quantile regression model (separately for each quantile) augmented with the Mundlak (1978) approach to purge unobserved heterogeneity. The reduced form second stage equation is

$$
y_{\tau, i t}=\phi_{\tau} D_{\tau, i t}+\psi_{\tau} \check{D}_{\tau, i t}+\beta_{\tau} X_{\tau, i t}+\omega_{\tau} \bar{V}_{i}+\epsilon_{\tau, i t}^{2 S R I}
$$

$\hat{D}_{i t}$ includes the residuals from the first stage crop diversification equations to correct for potential endogeneity between the welfare outcome and diversification. $\bar{V}_{i}$ are the mean of the time-varying covariates used in the outcome equation. Since the second-stage regressions include estimates from the first stage, the variance-covariance matrix of the estimators (standard errors) is computed through bootstrapping. To check robustness of our results, we also produce estimates using pooled quantile regression with the Mundlak approach without additional correction for endogeneity of crop diversity.

\subsubsection{Crop diversity and risk coping}

In this study, we also assess the impact of crop diversification on two risk coping measures which are binary outcome variables. Following Michler and Josephson (2017), for our binary response function, we assume that there is an underlying latent variable model:

$$
y_{i t}^{*}=\phi D_{i t}+\beta X_{i t}+\alpha_{i}+v_{i t}
$$

where $y_{i t}=1\left[y_{i t}^{*} \geq 0\right]$ for $t=1, \ldots, T$ and the other variables are as defined earlier. To recapitulate, we model crop diversification as in equation 3.5 as a linear function of the instruments and other covariates as follows:

$$
D_{i t}=\delta X_{i t}+\gamma Z_{i t}+c_{i}+\varepsilon_{i t}
$$

The impact of crop diversification $\left(D_{i t}\right)$ on risk coping $\left(y_{i t}\right)$ is estimated using alternative econometric methods that address the endogeneity of crop diversity. The primary estimation method is the 2 SRI or two-step control function method discussed 
above. ${ }^{6}$ The $2 \mathrm{SRI}$ is one of the instrumental variables (IV)-based approaches to correct for endogeneity bias due to the presence of unobservable confounders in nonlinear models (Terza et al., 2008; Wooldridge, 2014). Following Michler and Balagtas (2017) and Papke and Wooldridge (2008), we implement the 2SRI in two steps. First, we estimate the crop diversification model using pooled OLS with correlated random effects and clustered standard errors at the household. We save the generalized residuals from the first stage regressions. The second stage is implemented with correlated random effects probit (pooled maximum likelihood estimation) model of risk coping on crop diversification and other control variables. In this stage, the residuals saved from the first stage are included as additional regressors to control for endogeneity.

As a robustness check, we use the FE-IV method discussed above using linear probability models (Dercon et al., 2009; Michler and Josephson, 2017; Verkaart et al., 2017). Use of the linear probability model (LPM) is assuming the data generating process for the risk coping outcomes is linear. Estimation using LPM also provides coefficient estimates that are easy to interpret. As additional test for robustness of our results, we estimate our model using correlated random effects probit (pooled MLE) and fixed effects logit where we treat crop diversity as exogenous.

\subsection{DATA AND DESCRIPTIVE STATISTICS}

\subsubsection{Household Survey and Rainfall Data}

The data for the chapter come from the 2009-2012 waves of the Ugandan National Panel Survey (UNPS), a rich and nationally representative data administered by the Living Standards Measurement Study - Integrated Surveys on Agriculture (LSMSISA) program of the World Bank in collaboration with the Uganda Bureau of Statistics (UBoS). The survey collects detailed information on household characteristics, income sources, household assets, consumption expenditure, shocks and coping strategies, food security, land holdings, crop production and livestock ownership. The analytical sample is an unbalanced panel of rural households that are representative of rural Uganda. 7 Details of the description and summary of the main variables (covariates) used in the empirical models are presented in Table B.2 (Appendix B).

6 As an alternative to the two-step residual inclusion (2SRI) or control function approach, we follow Wooldridge (2014) and apply a one-step alternative using the pooled IV probit with correlated random effects. We use the ivprobit stata code with clustering the standard errors at the household to obtain valid inference. The Wald test of exogeneity of crop diversification fails to reject the null of no endogeneity in most of the risk coping (informal insurance) equations. This suggests that a pooled probit regression could be appropriate. Therefore, we proceed with the 2 SRI or two-step control function and add estimates using pooled CRE probit model as robustness check.

7 Details of the survey including sample size, sampling methods, data and other supporting materials can be accessed from the website: www.worldbank.org/lsms-isa. The UNPS has five waves of data including the 2005/06. The latest round (2013/14) is not used since it replaces about a third of the original households by new samples. According to the UNPS report in 2011/12, the attrition rate for the whole sample across the three waves used in this study is less than $5 \%$. 
Georeferencing of the households enables merging the survey data with climatic or agroecological characteristics. We extract historical rainfall data (1981-2010) from the Climate Hazards Group InfraRed Precipitation with Station (CHIRPS) data (Funk et al., 2015; Michler et al., 2018). CHRIPS generates satellite imagery with in-situ station gridded time series rainfall data. While the dataset provides daily rainfall measurements, we generate spatial rainfall data by scaling the data into monthly and seasonal rainfall measures. We use rainfall of the growing season in Uganda that lasts from October until April the following year.

\subsubsection{Crop diversification measures and patterns}

Crop diversification is measured using four interspecific crop diversity indices that capture both the number of crops in the crop production portfolio and their evenness: Count (richness), Shannon-Weaver, Composite entropy and Berger-Parker. The count index measures richness of cultivated crops and assumes that different crops contribute equally to the household crop portfolio, although this is not always the case (Benin et al., 2004; Di Falco et al., 2010; Jones et al., 2014; Saenz and Thompson, 2017). The Berger Parker Index measures relative abundance computed as the inverse weight of the most abundant crop (Benin et al., 2004). The Shannon-Weaver index measures the proportional abundance and evenness, an improvement over the two indices. Because its upper limit depends on the number of crops grown, it cannot be used to compare the degree of diversification in different locations where different numbers of crops are grown (Saenz and Thompson, 2017). The Composite entropy index, a modified version of the Shannon-Weaver index, measures both richness and evenness and enables the comparison of crop diversity across different locations, and thus overcomes the limitations of the Shannon-Weaver index (Ghosh et al., 2015; Arndt et al., 2015). Table B.I (Appendix B) summarizes the definition and computation of the four crop diversity indices. 
Table 3.1 Summary statistics for crop diversity pattern over the study years

\begin{tabular}{lcccc}
\hline \hline Crop diversity indices & $2009 / 10$ & $2010 / 11$ & $2011 / 12$ & Pooled \\
\hline Count Index & 5.78 & 5.98 & 5.31 & 5.67 \\
& $(2.20)$ & $(2.12)$ & $(1.98)$ & $(2.12)$ \\
Shannon-Weaver Index & 1.41 & 1.46 & 1.41 & 1.43 \\
& $(0.42)$ & $(0.40)$ & $(0.40)$ & $(0.41)$ \\
Composite Entropy Index & 0.67 & 0.68 & 0.69 & 0.60 \\
& $(0.15)$ & $(0.14)$ & $(0.14)$ & $(0.14)$ \\
Berger-Parker Index & 2.74 & 2.80 & 2.83 & 2.79 \\
& $(1.02)$ & $(1.02)$ & $(0.99)$ & $(1.01)$ \\
\hline Observations & 1,479 & 1,367 & 1,677 & 4,523 \\
\hline \hline
\end{tabular}

Note: Mean values reported; Standard deviations in parentheses.

Table 3.I summarizes the crop diversification pattern of the sample households. The count index shows that the average number of crops cultivated by the households is about 6 with a slight variation during the course of the panel. There appears to be no clear trend in crop diversification, particularly the count and Shannon-Weaver indices. The averages of the Shannon-Weaver and Berger-Parker indices are less than the count index. This indicates that land is not equally distributed to different crops cultivated by the households.

\subsubsection{Household welfare and risk coping}

We use real per adult-equivalent consumption expenditure (a flow measure) and household dietary diversity score (a stock measure) as indicators of household welfare (Upton et al., 2016). Current consumption is a preferred measure of welfare analysis over income since consumption is smoother than income and risk-averse households prefer less variable consumption (Bezu et al., 2014; Dercon, 2002). Consumption expenditure is computed as the sum of the value of food and non-food consumption, either from own production, from the market or gift or in-kind in the previous 30 days. The aggregate value is scaled to adult equivalent bases and expressed in Ugandan Shillings (USh) using constant base prices. Table 3.2 shows that real per adult equivalent consumption expenditure falls over the years 2009 and 2010. However, it remains nearly the same between 2010 and 2011. The household dietary diversity score (HDDS) is computed as the number of food groups (among 12 food groups) consumed by the household in a week before the survey. ${ }^{8}$ HDDs slightly decreased between 2009 and 2012.

8 The 12 food groups include: (i) cereals, (ii) roots tubers, (iii) vegetables, (iv) fruits, (v) meat and poultry, (vi) eggs, (vii) fish and seafood, (viii) pulses, (ix) milk and milk products, (x) oil/fats, (xi) sugar/honey, and (xii) miscellaneous food items. 
Table 3.2: Summary statistics of the outcome variables

\begin{tabular}{lcccc}
\hline \hline & $2009 / 10$ & $2010 / 11$ & $2011 / 12$ & Pooled \\
\hline Household welfare & & & & \\
Per adult equiv. consumption (X 1000 USh) & 51.16 & 44.98 & 43.39 & 46.41 \\
& $(35.36)$ & $(36.95)$ & $(33.63)$ & $(35.38)$ \\
Log per adult equiv. consumption (USh) & 10.66 & 10.48 & 10.47 & 10.53 \\
& $(0.62)$ & $(0.68)$ & $(0.68)$ & $(0.67)$ \\
Household dietary diversity score (HDDS) & 7.43 & 7.37 & 7.29 & 7.36 \\
& $(2.03)$ & $(2.28)$ & $(2.18)$ & $(2.16)$ \\
Risk coping/consumption smoothing & & & & \\
Informal insurance (1=Yes) & 0.141 & 0.179 & 0.176 & 0.165 \\
& $(0.348)$ & $(0.383)$ & $(0.381)$ & $(0.372)$ \\
Involuntary dietary change (1=Yes) & 0.381 & 0.238 & 0.128 & 0.244 \\
& $(0.486)$ & $(0.426)$ & $(0.334)$ & $(0.430)$ \\
\hline Observations & 1,479 & 1,367 & 1,677 & 4,523 \\
\hline \hline
\end{tabular}

Note: Mean values reported and standard deviations in parentheses. Reported per adult equivalent consumption expenditure values are after winsorizing top $1 \%$. Log per adult equivalent consumption expenditure is based on log transformation of the original values.

Rural Ugandans face various shocks that affect their welfare. The shocks can be of climatic (drought, pestilence affecting crops and livestock), economic or market origin (large increase in prices of inputs, decrease in output prices), and health-related (illness and death of household members) (Dercon et al., 2005; Veljanoska, 2014). In the aftermath of shocks, households implement a wide array of strategies to deal with the welfare impacts of the shocks and decrease risk exposure. Risk-coping strategies are ex-post shock coping strategies that would help households smooth consumption (Alderman and Paxson, 1994). The choice of coping strategies also depends on the nature of the climate shock and the degree of impact on household access to food and income.

To investigate the impact of crop diversification on risk coping or consumption smoothing, two risk coping strategies are considered: informal insurance and involuntary change in diets. These strategies are usually considered in the absence of formal risk coping mechanisms (Deaton, 1991; Dercon, 2002; Dercon and Christiaensen, 2011; Gao and Mills, 2018). Informal insurance includes cash or in-kind support provided by community or family members. It is not an effective strategy for maintaining consumption or welfare in times of covariate shocks (Barrett et al., 2001; Dercon, 2002). Involuntary diet change is a negative post-shock response that involves reliance on less preferred food items, food rationing or cutting the size and number of daily consumptions. These two risk coping strategies are unproductive and provide limited 
support (Dercon, 2002). Table 3.2 shows that about $17 \%$ of the sample households rely on informal insurance as a shock coping mechanism. There has been an increase in use of informal insurance as a consumption smoothing strategy over the study timeframe. About $24 \%$ of the sample households involuntarily change their diets or consumption as a risk coping strategy. The proportion, however, significantly decreased from $38 \%$ in 2009 to $13 \%$ in 2012.

\subsection{RESULTS AND DISCUSSIONS}

\subsubsection{Drivers of crop diversification}

Table 3.3 provides the results for drivers of crop diversification obtained from a correlated random effects (CRE) model. The model diagnostic results show that the mean of the time-varying variables is jointly significant in the crop diversification model, which suggests the presence of unobserved heterogeneity and justifies the use of the CRE model. The instruments are also jointly significant in all of the crop diversity regressions. Rainfall shock is found to be significant determinant of crop diversification. This finding suggests that households have an incentive for using crop diversification as an adaptation strategy against weather anomalies (Di Falco et al., 2010; Bezabih and Di Falco, 2012; Arslan et al., 2018; Asfaw et al., 2018). The degree of crop diversification also increases with elevation. The positive and significant coefficient on elevation suggests that households located in the higher altitude zones are more likely to grow diversified crops. This could be due to different climatic conditions and agronomic possibilities (Van Dusen and Taylor, 2005). Although average temperature of the planting season has no significant effect on crop diversification, the interaction of temperature with elevation has negative effect on crop diversification. The significant effect of elevation and its interaction with temperature provides evidence that environmental heterogeneity plays a key role in determining crop diversity. We also find that village level crop diversity is a strong predictor of crop diversity which suggests that households' production choices are influenced by neighbourhood effects. 
Table 3.3: Drivers of crop diversity: Estimates from Panel Correlated Random Effects

\begin{tabular}{|c|c|c|c|c|}
\hline & Count Index & Shannon-Weaver & Composite Entropy & Berger-Parker \\
\hline \multirow[t]{2}{*}{ Age of head } & $0.025^{* * *}$ & $0.005^{* *}$ & 0.001 & $0.009^{*}$ \\
\hline & (o.oog) & $(0.002)$ & $(0.001)$ & $(0.005)$ \\
\hline \multirow[t]{2}{*}{ Male headed } & $-0.381^{*}$ & -0.021 & 0.004 & 0.001 \\
\hline & $(0.207)$ & (o.044) & (о.018) & (0.122) \\
\hline \multirow[t]{2}{*}{ Household size } & 0.058 & $0.012^{*}$ & 0.004 & 0.027 \\
\hline & $(0.041)$ & (0.007) & $(0.002)$ & (0.018) \\
\hline \multirow[t]{2}{*}{ Head education } & 0.124 & $0.037^{*}$ & 0.013 & 0.055 \\
\hline & (0.106) & $(0.021)$ & (o.0o8) & (0.059) \\
\hline \multirow[t]{2}{*}{ Asset value (log) } & $0.057^{* *}$ & $0.010^{* *}$ & 0.003 & 0.006 \\
\hline & $(0.023)$ & (0.005) & (0.002) & (0.012) \\
\hline \multirow[t]{2}{*}{ Land size } & $0.262^{* * *}$ & $0.040^{* * *}$ & $0.008^{* *}$ & $0.067^{* * *}$ \\
\hline & $(0.042)$ & (o.0o9) & (o.003) & (o.024) \\
\hline \multirow[t]{2}{*}{ Livestock holding } & -0.001 & 0.005 & $0.002^{*}$ & 0.010 \\
\hline & (0.015) & (0.003) & (o.001) & (o.oo8) \\
\hline \multirow[t]{2}{*}{ Remittances } & -0.066 & -0.004 & 0.001 & -0.009 \\
\hline & $(0.082)$ & (0.017) & $(0.007)$ & $(0.046)$ \\
\hline \multirow[t]{2}{*}{ Distance to road } & 0.010 & 0.001 & -0.000 & 0.008 \\
\hline & $(0.058)$ & (o.0o9) & (o.003) & $(0.025)$ \\
\hline \multirow[t]{2}{*}{ Distance to market } & $0.037^{* *}$ & $0.013^{* * *}$ & $0.005^{* *}$ & 0.014 \\
\hline & (0.016) & $(0.004)$ & $(0.002)$ & (0.010) \\
\hline \multirow[t]{2}{*}{ Rainfall shock } & $0.245^{* * *}$ & $0.047^{* *}$ & $0.014^{*}$ & $0.086^{*}$ \\
\hline & $(0.083)$ & $(0.020)$ & (o.0o8) & $(0.050)$ \\
\hline \multirow[t]{2}{*}{ Mean temperature } & 1.892 & 0.383 & 0.123 & 1.197 \\
\hline & $(1.426)$ & $(0.280)$ & (o.099) & $(0.741)$ \\
\hline \multirow[t]{2}{*}{ Elevation } & 20.764 & $5.681^{*}$ & $2.063^{*}$ & $14.683^{*}$ \\
\hline & $(16.168)$ & $(3.078)$ & (1.086) & $(8 \cdot 370)$ \\
\hline \multirow[t]{2}{*}{ Temperature X Elevation } & -0.739 & $-0.218^{*}$ & $-0.081^{*}$ & -0.561 \\
\hline & $(0.739)$ & $(0.132)$ & $(0.048)$ & $(0.374)$ \\
\hline \multirow[t]{2}{*}{ Village crop diversity } & $0.335^{* * *}$ & $0.299^{* * *}$ & $0.231^{* * *}$ & $0.255^{* * *}$ \\
\hline & $(0.043)$ & $(0.042)$ & $(0.046)$ & (o.049) \\
\hline Mundlak variables & $78.01^{* * *}$ & $91.57^{* * *}$ & $62.73^{* * *}$ & $48.06^{* * *}$ \\
\hline Joint significance of instruments & $76.51^{* * *}$ & $63 \cdot 38^{* * *}$ & $39.20^{* * *}$ & $34 \cdot 53^{* * *}$ \\
\hline Region & Yes & Yes & Yes & Yes \\
\hline Year & Yes & Yes & Yes & Yes \\
\hline Region X Year & Yes & Yes & Yes & Yes \\
\hline \multirow[t]{2}{*}{ Constant } & 4.108 & 0.630 & 0.229 & 0.950 \\
\hline & $(3.027)$ & (o.657) & $(0.242)$ & $(1.516)$ \\
\hline Observations & 4523 & 4523 & 4523 & 4521 \\
\hline$\chi^{2}$ & $1156.27^{* * *}$ & $741.60^{* * *}$ & $345 \cdot 57^{* * *}$ & $405.43^{* * *}$ \\
\hline
\end{tabular}

Note: The Mundlak variables report the joint significance of the average of time-varying variables. Clustered standard errors in parentheses; ${ }^{*} p<0.10,{ }^{* *} p<0.05,{ }^{* * *} p<0.01$ 
Household demographic characteristics play an important role in determining the scope and degree of crop diversity. Age of the household head has a positive correlation with all crop diversity metrics except the composite entropy index. This suggests that older farmers cultivate more crops and diversify than younger farmers. This finding also raises the prospect for an intergenerational decline in crop diversity. The positive correlation between age and crop diversity could be interpreted in two ways. First, farming experience is highly associated with age and experienced farmers are very likely to adopt crop diversification since they will have knowledge about its benefits. Second, technology mistrust increases with farmers' age (Bezu et al., 2014) and older farmers would prefer to rely on crop diversification (a lower risk activity) as a risk management strategy than other potentially risky options (Bezabih and Sarr, 2012). Crop diversity is also found to be correlated with gender of the household head, education of the head, household size and livestock holdings. However, the effects are marginal and significant only for few of the crop diversity indices.

Consistent with economic theory and empirical studies, we find evidence that crop portfolio choice varies with household wealth (Rosenzweig and Wolpin, 1993; Dercon, 1996). Crop diversification (count and Shannon indices) is positively associated with asset wealth. The results also show that the scope and degree of crop diversification is positively correlated with the size of land cultivated regardless of the crop diversity metrics. This indicates the important role of the size of landholding on crop management decisions. Benin et al. (2004) also find that Ethiopian households with larger farms grow more diverse cereal crops. We find the degree of crop diversification to increase with distance to the nearest market. The significant relationship holds for all crop diversity indices except the Berger-Parker index. The finding is consistent with economic theory that asserts greater diversification as a strategy to insure consumption from own production for households located far from markets. Arslan et al. (2018) also show that crop diversification increases with increase in the distance to markets in Zambia.

\subsubsection{Welfare effects of crop diversification}

\subsubsection{Crop diversification and aggregate household diets}

Results from the fixed-effects instrumental variables (FE-IV) regression show that crop diversification has a positive impact on household dietary diversity (Table 3.4). On average, adding 1 more crop to the portfolio (count index) is associated with an increase in the dietary diversity score by 0.16 . The small magnitude of the effect indicates that increasing crop diversity may not be sufficient to ensure improved dietary diversity (Dillon et al., 2015). The result is fairly comparable with that of Koppmair et al. (2017). A 1 unit increase in the evenness of the area allocated across crops in the portfolio (Shannon-Weaver) increases dietary diversity score by 1.32 on average. Even a 1 unit increase in the equitable allocation of land among crops (Composite entropy index) 
leads to an increase in household dietary diversity by more than 4 . The findings suggest that crop diversification through increased equitable allocation of land across crops generates better dietary diversity benefits than crop diversification through the mere addition of crops.

Table B.3 (Appendix B) reports the full set of results including the diagnostics tests related to the instruments for crop diversification. The Kleibergen-Paap F statistic (test for weak identification) is significant and above o in all specifications which justifies the strength and relevance of the selected instruments. The results show that, with a $95 \%$ confidence, our IV estimates have less than $5 \%$ of OLS bias (Dercon et al., 2009). The Hansen J (Sargan-Hansen) Statistic, a test of overidentification, is not statistically significant. This shows that we do not have enough evidence to reject the null hypothesis that our instruments can be excluded from the second stage regressions. The results from the tests confirm the strength and validity of the instruments.

Table 3.4: Effects of crop diversity on aggregate household dietary diversity

\begin{tabular}{lcccc}
\hline \hline & Count index & Shannon-Weaver & Composite Entropy & Berger-Parker \\
\hline (1) FE-IV & $0.158^{* *}$ & $1.317^{* * *}$ & $4.682^{* * *}$ & $0.648^{* * *}$ \\
& $(0.049)$ & $(0.262)$ & $(0.935)$ & $(0.127)$ \\
(2) 2SRI & $0.104^{*}$ & $0.976^{* * *}$ & $2.538^{* * *}$ & $0.352^{* * *}$ \\
& $(0.060)$ & $(0.305)$ & $(0.978)$ & $(0.118)$ \\
(3) FE-Poisson & $1.008^{* * *}$ & $1.051^{* * *}$ & $1.135^{* * *}$ & $1.012^{* *}$ \\
& $(0.003)$ & $(0.013)$ & $(0.004)$ & $(0.005)$ \\
(4) Pooled OLS & $0.153^{* * *}$ & $0.619^{* * *}$ & $1.195^{* * *}$ & $0.162^{* * *}$ \\
& $(0.017)$ & $(0.083)$ & $(0.230)$ & $(0.031)$ \\
\hline \hline
\end{tabular}

Note: Dependent variable is household dietary diversity score. (1) Reports, for the purpose of comparison, the results found in Table B.3 (Appendix B). (2) reports results of an alternative specification of the dietary diversity equation using a 2SRI method with bootstrap cluster standard errors; (3) reports incidence-rate ratios (IRR) from Fixed Effects-Poisson regressions and (4) reports estimates from the pooled OLS regressions. Robust clustered standard errors in all regressions; ${ }^{*} p<0.10,{ }^{* *} p<0.05,{ }^{* * *}$ $p<0.01$.

Results from the FE-IV regressions are comparable with estimates obtained using the 2 SRI model. The coefficients of the crop diversity indices appear to be fairly consistent across the two specifications. This is expected since two-stage least squares (2SLS) methods such as FE-IV and 2SRI methods are supposed to give equivalent results in linear models. The discrepancy in the results is perhaps we use different approaches in the second-stage estimations. In addition to the 2 SRI, we check robustness of our results using Fixed Effects-Poisson and OLS regressions where we assume crop diversity to be exogenous. Estimates using pooled OLS also help to test if results are 
different if we assume crop diversity and household diet diversity do not change over time. While both the FE-Poisson and the pooled OLS models show a positive and significant effect of crop diversification on dietary diversity, the estimates from pooled OLS are conservative compared to results from the FE-IV and 2SRI methods.

Our findings are in compliance with the findings of recent studies that demonstrate a positive association between crop diversification and aggregate household nutrition (Jones et al., 2014; Dillon et al., 2015; Sibhatu et al., 2015; Makate et al., 2016). All in all, the results underscore that crop diversity can be a useful strategy to improve nutrition and food security in areas where the triple challenges of malnutrition and micronutrient deficiencies are ubiquitous (Sibhatu et al., 2015; Romeo et al., 2016).

\subsubsection{Crop diversification and consumption}

Table 3.5 provides the coefficient estimates of the consumption expenditure equations obtained using the FE-IV model. The diagnostic test results show that the instruments for crop diversity are valid (table B.5 in Appendix B). The coefficients on crop diversity are positive and statistically significant for all crop diversity indices. This indicates that crop diversification exerts a positive impact on household welfare represented by real per adult equivalent consumption expenditure. Increase in the number of crops grown in the household by 1 leads to about a $4.5 \%$ increase in per adult equivalent consumption expenditure. On average, a 1 unit increase in the equitable allocation of land across crops (Shannon-Weaver index) leads to an increase in the per adult equivalent consumption expenditure of $25.6 \%$. Comparing the point coefficient estimate of the Count and Shannon-Weaver indices, we conclude that increase in equitable allocation of land among cultivated crops provides higher consumption effects than the increase in the number of crops. 
Table 3.5: Effects of crop diversity on consumption expenditure

\begin{tabular}{lcccc}
\hline \hline & Count index & Shannon-Weaver & Composite Entropy & Berger-Parker \\
\hline (1) FE-IV & $0.045^{* *}$ & $0.256^{* *}$ & $0.763^{*}$ & $0.132^{* *}$ \\
& $(0.020)$ & $(0.108)$ & $(0.403)$ & $(0.055)$ \\
(2) 2SRI & $0.039^{* *}$ & $0.215^{* * *}$ & 0.426 & 0.055 \\
& $(0.015)$ & $(0.081)$ & $(0.267)$ & $(0.035)$ \\
(3) CRE & $0.010^{*}$ & 0.025 & 0.037 & 0.008 \\
& $(0.005)$ & $(0.024)$ & $(0.066)$ & $(0.009)$ \\
(4) Pooled OLS & $0.020^{* * *}$ & 0.023 & -0.069 & -0.004 \\
& $(0.005)$ & $(0.023)$ & $(0.064)$ & $(0.008)$ \\
\hline \hline
\end{tabular}

Note: Dependent variable is the log of per adult equivalent household consumption expenditure. (1) reports, for the purpose of comparison, the results found in table B.3 (Appendix B). (2) reports results of an alternative specification of the consumption expenditure equation using a $2 \mathrm{SRI}$ method; (3) reports results from CRE regression, and (4) reports estimates from pooled OLS regression. Robust clustered standard errors in all regressions; ${ }^{*} p<0.10,{ }^{* *} p<0.05,{ }^{* * *} p<0.01$.

The estimates from the FE-IV are contrasted with estimates from the two-stage residual inclusion (2SRI) method. The coefficients of the generalized residuals are significant in almost all the consumption expenditure equations whenever crop diversity exerts a significant effect. This compels us to reject the exogeneity of crop diversity in the household welfare equations. The results from the 2SRI method also show that crop diversity has a positive and significant effect on consumption expenditure. Both increase in the number of crops in the production portfolio (Count Index) and increase in the equitable allocation of land across the crops cultivated (Shannon-Weaver index) have a positive and significant effect on per adult equivalent consumption expenditure. The results from the FE-IV model are also contrasted with results obtained from CRE and pooled OLS where we treat crop diversification as exogenous. The results are positive and significant only for the Count index.

\subsubsection{Heterogeneous effects of crop diversity on consumption}

We assess the effect of crop diversity on four different quantiles of household consumption using quantile-IV regression to test if crop diversification has heterogeneous effects on consumption among low consuming (poor) and high consuming (richer) households. Table 3.6 summarizes the coefficient estimates from the quantile regression (full results in tables B.7 - B.10, Appendix B). In the 2SRI model that addresses endogeneity, only the count and Shannon-Weaver indices have significant effects on household consumption, and the effects are unambiguously higher for low consuming households. The coefficient estimates for the Shannon-Weaver index shows that the size of the impact on the poorest group or those at the lowest quantile band (0.423) is about double the impact on the richest group (0.231). This suggests that low con- 
suming households that increase their level of crop diversity will reap greater returns to their production portfolio in terms of increased consumption. This finding can be explained by the theoretical and empirical link between wealth and risk-taking. Since low consuming households are very likely to be risk-averse due to low initial wealth conditions, they could adopt crop diversification as a livelihood strategy. In contrast, high consuming households are wealthier and thus could have alternative risk management options. Our findings agree with the study by Asfaw et al. (2018) that reaches similar conclusion in their study based in Malawi.

Table 3.6: Welfare effects of crop diversity: quantile regression estimates

\begin{tabular}{|c|c|c|c|c|c|c|c|c|}
\hline & \multicolumn{4}{|c|}{ Endogenous crop diversity } & \multicolumn{4}{|c|}{ Exogenous crop diversity } \\
\hline & $20 \%$ & $40 \%$ & $60 \%$ & $80 \%$ & $20 \%$ & $40 \%$ & $60 \%$ & $80 \%$ \\
\hline \multirow[t]{2}{*}{ Count index } & $0.112^{* * *}$ & $0.094^{* * *}$ & $0.082^{* * * *}$ & $0.080^{* * *}$ & $0.017^{*}$ & $0.022^{* * *}$ & $0.015^{*}$ & $0.015^{*}$ \\
\hline & (0.026) & $(0.022)$ & $(0.021)$ & $(0.020)$ & (0.009) & (0.008) & (o.oo8) & (o.009) \\
\hline \multirow[t]{2}{*}{ Shannon-Weaver } & $0.423^{* * *}$ & $0.382^{* * *}$ & $0.247^{* *}$ & $0.231^{* *}$ & $0.094^{* *}$ & $0.077^{* *}$ & $0.062^{*}$ & 0.049 \\
\hline & $(0.085)$ & (0.109) & (0.111) & (0.111) & $(0.041)$ & (o.037) & (o.037) & $(0.042)$ \\
\hline \multirow[t]{2}{*}{ Composite entropy } & 0.396 & 0.198 & -0.231 & -0.026 & $0.210^{* *}$ & 0.150 & 0.134 & 0.007 \\
\hline & $(0.388)$ & $(0.426)$ & $(0.296)$ & (o.333) & (0.106) & (0.099) & (o.099) & $(0.116)$ \\
\hline \multirow[t]{2}{*}{ Berger-Parker } & 0.051 & 0.040 & 0.042 & 0.041 & $0.031^{* *}$ & 0.017 & 0.021 & 0.018 \\
\hline & $(0.064)$ & (o.049) & (o.049) & $(0.056)$ & (0.015) & (0.014) & $(0.014)$ & (0.016) \\
\hline
\end{tabular}

Note: Dependent variable is real consumption expenditure per adult equivalent. Bootstrapped standard errors with 500 replications in parentheses. All regressions include control variables, time averages of time varying variables and year dummy; ${ }^{*} p<0.10,{ }^{* *} p<0.05,{ }^{* * *} p<0.01$

To test the robustness of the results, we estimate the model using a pooled quantile regression with the Mundlak device to deal with unobserved heterogeneity where crop diversity is considered to be exogenous. Even when we do not allow for endogeneity of crop diversity, we conclude that crop diversity generates higher consumption effects for low consuming (poor) households. While the Count and ShannonWeaver indices appear to be significant in most of the consumption quantile equations, the Composite entropy and Berge-Parker indices are positive and significant only for the lowest consumption expenditure quantile. The findings from the quantile regressions also confirm that increase in equitable allocation of land among crops produces higher consumption benefits for low-consuming households.

\subsubsection{Crop diversification and risk coping}

We assess the effect of crop diversification on two commonly employed coping strategies by rural Ugandan households: informal insurance and involuntary diet change (table 3.7). First, we estimate the impacts using the 2SRI method. The estimates show that crop diversification has negative effect on risk coping through informal insurance. 
The coefficients of crop diversity are significant for all crop diversity indices except the Composite entropy index. The estimated effect is significant for involuntary change in diets for the Count index only.

Table 3.7: Impact of crop diversity on risk coping

\begin{tabular}{lcccc}
\hline \hline & Count index & Shannon-Weaver & Composite Entropy & Berger-Parker \\
\hline A: Informal insurance & & & & \\
(1) 2SRI & $-0.018^{* *}$ & $-0.074^{* *}$ & -0.091 & $-0.036^{*}$ \\
& $(0.009)$ & $(0.036)$ & $(0.145)$ & $(0.022)$ \\
(2) FE-IV & -0.008 & $-0.151^{*}$ & $-0.719^{* *}$ & $-0.093^{* *}$ \\
& $(0.016)$ & $(0.082)$ & $(0.300)$ & $(0.042)$ \\
(3) CRE probit & $-0.007^{* *}$ & $-0.057^{* * *}$ & $-0.146^{* * *}$ & $-0.023^{* * *}$ \\
& $(0.004)$ & $(0.017)$ & $(0.042)$ & $(0.006)$ \\
(4) Fixed effects logit & $-0.085^{*}$ & $-0.664^{* * *}$ & $-1.788^{* * *}$ & $-0.287^{* * *}$ \\
& $(0.047)$ & $(0.230)$ & $(0.639)$ & $(0.088)$ \\
B: Change in diets & & & & -0.001 \\
(1) 2SRI & $-0.024^{* *}$ & -0.049 & 0.182 & $(0.024)$ \\
& $(0.011)$ & $(0.051)$ & $(0.158)$ & -0.083 \\
(2) FE-IV & $-0.032^{*}$ & $-0.198^{*}$ & $-0.676^{*}$ & $(0.052)$ \\
& $(0.019)$ & $(0.101)$ & $(0.371)$ & 0.006 \\
(3) CRE probit & $-0.007^{*}$ & -0.008 & 0.005 & $(0.007)$ \\
& $(0.004)$ & $(0.018)$ & $(0.049)$ & 0.074 \\
(4) Fixed effects logit & -0.016 & 0.083 & 0.337 & $(0.073)$ \\
\hline \hline
\end{tabular}

Note: (1) reports average partial effects (APEs) from the 2SRI or control function method; (2) reports fixed effects-IV regression results; (3) reports APEs from CRE probit (pooled maximum likelihood estimations), and (4) reports fixed effects logit coefficients; All regressions include control variables; (1) and (3) include time averages of all explanatory variables, year and region dummies. Standard errors in parentheses are clustered at the household level; ${ }^{*} p<0.10,{ }^{* *} p<0.05,{ }^{* *} p<0.01$.

We also estimate the impacts of crop diversification using the FE-IV LPM model. The various tests for the instruments for crop diversification justify the validity of the selected instruments (tables B.II and B.12, Appendix B). Results from the FE-IV regression show that crop diversification (with the exception of the Count index) has a negative and significant effect on informal insurance (table 3.7, panel A, row (1)). The findings from the 2SRI and FE-IV, although the magnitudes are somehow different, indicate that crop diversification reduces the need for informal insurance as a risk coping strategy. Since informal insurance in the form of reliance on relatives or friends is a common form of risk-sharing arrangement for risk coping (Alderman and Paxson, 1994), the results suggest that ex-ante diversification reduces the likelihood of reliance on risk-sharing arrangements. Results from the FE-IV model also show that crop di- 
versification has negative effect on involuntary change of diets or consumption. With the exception of the Berger-Parker index, all crop diversity measures are negatively associated with risk coping through involuntary diet change. However, the effects are significant only at $10 \%$ significance level.

Table 3.7 also provides estimates of the risk coping (consumption smoothing) equations obtained using various estimation methods for robustness check. In row (3), we report estimates obtained using pooled correlated random effects probit model, an alternative specification where crop diversity is treated as exogenous. The marginal effects of crop diversity turn to be significant for informal insurance. In row (4), we report results from fixed effects (conditional) logit regressions. The results show that risk coping through informal insurance is negatively associated with crop diversity. However, the correlations are insignificant for involuntary change in diets equations. The results from the CRE probit (pooled MLE) and fixed effects logit models are comparable with the estimates from our preferred model for informal insurance. Overall, results from the FE-IV, 2 SRI and the alternative specifications show that crop diversity reduces households' reliance on the solidarity of their social networks ex-post shock as a risk coping or consumption smoothing strategy.

\section{$3 \cdot 7$ CONCLUSION}

Rural households face a plethora of shocks that have substantial repercussions on their well-being and adaptive capacity. In an environment characterized by absent or poorly functioning insurance and credit markets, agricultural households adopt crop diversity as a self-insuring mechanism for risk management. Due to its role in mitigating the effects of climate change, building agricultural resilience and enhancing food security, crop diversification appears to be one of the climate-smart agricultural practices. The chapter contributes to the growing literature and the policy discourse by empirically investigating the effect of crop diversification on household welfare and risk coping in Uganda using panel survey data merged with historical rainfall data. We explore how increasing crop diversity through expanding crop portfolio and increasing the equitable allocation of land across cultivated crops balances the goals of welfare maximizing and hedging climate-induced risks. We utilize panel data estimators integrated with instrumental variables methods to estimate the effect of crop diversification on household welfare and risk coping while controlling for potential endogeneity. A series of crop diversity indices are used to capture the different facets of crop diversity and to test the robustness of results across various crop diversity metrics.

Results of the analyses show that crop diversification improves household welfare as indicated by the positive and significant effects on dietary diversity and consumption expenditure. Furthermore, the consumption effect of crop diversity is more pronounced among households positioned at the lowest quantile of the consumption dis- 
tribution than richer and high-consuming households. Although both the cultivation of more crops and the equitable distribution of land across crops improve household welfare, crop diversification through increase in the equitable allocation of land across crops generates higher welfare benefits. We also find that crop diversification reduces households' reliance on informal insurance as a risk-coping or consumption smoothing mechanism. The results of the study show that households' crop diversification decisions are significantly affected by climatic conditions, market access, household wealth and village level crop diversification. This suggests that policies to promote crop diversification might need to focus in areas with limited access to markets and with high agroecological heterogeneity.

The findings suggest that crop diversification is a climate-smart practice and could be an option for increasing resilience and risk mitigation behavior in the context of climatic shocks and incomplete insurance markets. The study contributes evidence to the burgeoning literature and the findings provide inputs for the current policy and development agenda in Africa such as the Comprehensive Africa Agricultural Development Program (CAADP) aimed at poverty reduction and accelerating Africa's growth. Importantly, the results of this study are in favor of the current policy focus that promotes crop diversification. If crop diversification is to contribute to the successful economic diversification and agricultural transformation in rural Africa, alleviating the structural and technical impediments needs to be a policy priority. Although we may safely conclude that increasing crop diversity through expanding the crop portfolio and equitable allocation of land across crops could boost household welfare, it may also affect the use of agricultural inputs (e.g., chemical fertilizer and improved seeds) if land is reallocated away from crops that use these inputs intensively. Exploring this effect by linking input use and the productivity effects of crop diversity could be of interest in the literature. Further research is also needed to explore how the scope and benefits of crop diversity in SSA are affected by the small farm holding size, resource endowment constraints, and infrastructure. 
Adger, W. N., Dessai, S., Goulden, M., Hulme, M., Lorenzoni, I., Nelson, D. R., Naess, L. O., Wolf, J., and Wreford, A. (2009). Are there social limits to adaptation to climate change? Climatic Change, 93(3-4):335-354.

Ahmadzai, H. (2017). Crop diversification and technical efficiency in Afghanistan: Stochastic frontier analysis. Technical report, CREDIT Research Paper.

Alderman, H. and Paxson, C. H. (1994). Do the poor insure? a synthesis of the literature on risk and consumption in developing countries. In Economics in a Changing World, pages $48-78$. Springer.

Angrist, J. D. and Krueger, A. B. (2001). Instrumental Variables and the Search for Identification: From Supply and Demand to Natural Experiments. Journal of Economic Perspectives, 15(4):69-85.

Arndt, C., Pauw, K., and Thurlow, J. (2015). The economy-wide impacts and risks of Malawi's farm input subsidy program. American Journal of Agricultural Economics, 98(3):962-980.

Arslan, A., Cavatassi, R., Alfani, F., Mccarthy, N., Lipper, L., and Kokwe, M. (2018). Diversification Under Climate Variability as Part of a CSA Strategy in Rural Zambia. Journal of Development Studies, 54(3):457-480.

Asfaw, S., Pallante, G., and Palma, A. (2018). Diversification strategies and adaptation deficit: Evidence from rural communities in Niger. World Development, 101:219-234.

Barrett, C., Reardon, T., and Webb, P. (2001). Nonfarm income diversification and household livelihood strategies in rural Africa: Concepts, dynamics, and policy implications. Food Policy, 26(4):315-331.

Baumgärtner, S. and Quaas, M. F. (2010). Managing increasing environmental risks through agrobiodiversity and agrienvironmental policies. Agricultural Economics, $41(5): 483-496$.

Benin, S., Smale, M., Pender, J., Gebremedhin, B., and Ehui, S. (2004). The economic determinants of cereal crop diversity on farms in the Ethiopian highlands. Agricultural Economics, 31(2-3 SPEC. ISS.):197-208.

Benson, T., Mugarura, S., and Wanda, K. (2008). Impacts in Uganda of rising global food prices: The role of diversified staples and limited price transmission. Agricultural Economics, 39:513-524. 
Bezabih, M. and Di Falco, S. (2012). Rainfall variability and food crop portfolio choice: Evidence from Ethiopia. Food Security, 4(4):557-567.

Bezabih, M. and Sarr, M. (2012). Risk Preferences and Environmental Uncertainty: Implications for Crop Diversification Decisions in Ethiopia. Environmental and Resource Economics, 53:483-505.

Bezu, S., Kassie, G. T., Shiferaw, B., and Ricker-Gilbert, J. (2014). Impact of improved maize adoption on welfare of farm households in Malawi: A panel data analysis. World Development, 59:120-131.

Binswanger, H. P. (1983). Agricultural growth and rural nonfarm activities. Finance and Development, 20(2):38.

Birthal, P. S., Roy, D., and Negi, D. S. (2015). Assessing the impact of crop diversification on farm poverty in India. World Development, 72(i):70-92.

Bradshaw, B., Dolan, H., and Smit, B. (2004). Farm-level adaptation to climatic variability and change: Crop diversification in the Canadian prairies. Climatic Change, 67(1):119-141.

Cameron, A. C. and Trivedi, P. K. (2010). Microeconometrics using Stata, volume 2. Stata press College Station, TX.

Chamberlain, G. (1982). Multivariate regression models for panel data. Journal of Econometrics, 18(1):5-46.

Chavas, J.-P. and Di Falco, S. (2012). On the Productive Value of Crop Biodiversity: Evidence from the Highlands of Ethiopia. Land Economics, 88(1):58-74.

Chibwana, C., Fisher, M., and Shively, G. (2012). Cropland Allocation Effects of Agricultural Input Subsidies in Malawi. World Development, 4O(1):124-133.

Conley, T. G. and Udry, C. R. (2010). Learning about a New Technology: Pineapple in Ghana. American Economic Review, 100(1):35-69.

Coromaldi, M., Pallante, G., and Savastano, S. (2015). Adoption of modern varieties, farmers' welfare and crop biodiversity: Evidence from Uganda. Ecological Economics, 119:346-358.

Covarrubias, K. A. (2015). The role of crop diversity in household production and food security in Uganda: A gender-differentiated analysis.

De Janvry, A. and Sadoulet, E. (2006). Progress in the modeling of rural households' behavior under market failures. In Poverty, inequality and development, pages 155-181. Springer. 
Bibliography

Deaton, A. (1991). Saving and Liquidity Constraints. Econometric Theory, 59(5):12211248.

Dercon, S. (1996). Risk, Crop Choice, and Savings: Evidence from Tanzania. Economic Development and Cultural Change, 44(3):485-513.

Dercon, S. (2002). Income risk, coping strategies, and safety nets. The World Bank Research Observer, 17(2):141-166.

Dercon, S. (2004). Growth and shocks: Evidence from rural Ethiopia. Journal of Development Economics, 74(2):309-329.

Dercon, S. and Christiaensen, L. (2011). Consumption risk, technology adoption and poverty traps: Evidence from Ethiopia. Journal of Development Economics, 96(2):159173 .

Dercon, S., Gilligan, D. O., Hoddinott, J., and Woldehanna, T. (2009). The impact of agricultural extension and roads on poverty and consumption growth in fifteen Ethiopian villages. American Journal of Agricultural Economics, 91(4):1007-1021.

Dercon, S., Hoddinott, J., and Woldehanna, T. (2005). Shocks and consumption in 15 Ethiopian villages, 1999-2004. Journal of African Economies, 14(4):559-585.

Di Falco, S., Adinolfi, F., Bozzola, M., and Capitanio, F. (2014). Crop Insurance as a Strategy for Adapting to Climate Change. Journal of Agricultural Economics, 65(2):485-504.

Di Falco, S., Bezabih, M., and Yesuf, M. (2010). Seeds for livelihood: Crop biodiversity and food production in Ethiopia. Ecological Economics, 69(8):1695-1702.

Di Falco, S. and Chavas, J. P. (2009). On crop biodiversity, risk exposure, and food security in the highlands of Ethiopia. American Journal of Agricultural Economics, 91(3):599-611.

Di Falco, S. and Perrings, C. (2005). Crop biodiversity, risk management and the implications of agricultural assistance. Ecological Economics, 55(4):459-466.

Dillon, A., McGee, K., and Oseni, G. (2015). Agricultural production, dietary diversity and climate variability. Journal of Development Studies, 51(8):976-995.

Donfouet, H. P. P., Barczak, A., Détang-Dessendre, C., and Maigné, E. (2017). Crop Production and Crop Diversity in France: A Spatial Analysis. Ecological Economics, 134:29-39.

Dzanku, F. M. and Sarpong, D. (2011). Agricultural Diversification, Food Self Sufficiency and Food Security in Ghana. Number June. CABI, Wallingford, UK. 
Ecker, O. and Qaim, M. (2011). Analyzing Nutritional Impacts of Policies: An Empirical Study for Malawi. World Development, 39(3):412-428.

Ellis, F. (2000). The Determinants of Rural Livelihood Diversification in Developing Countries. Journal of Agricultural Economics, 51(2):289-302.

Fafchamps, M. (1992). Cash Crop Production, Food Price Volatility, and Rural Market Integration in the Third World. American Journal of Agricultural Economics, 74(1):9099 .

FAO (2012). Crop diversification for sustainable diets and nutrition: The role of FAO'S Plant Production and Protection Division. Technical report, Food and Agriculture Organization of the United Nations (FAO), Rome.

Feder, G., Just, R. E. ., and Zilberman, D. (1985). Adoption of Agricultural Innovations in Developing Countries: A Survey. Economic Development and Cultural Change, 33(2):255-298.

Funk, C., Peterson, P., Landsfeld, M., Pedreros, D., Verdin, J., Shukla, S., Husak, G., Rowland, J., Harrison, L., and Hoell, A. (2015). The climate hazards infrared precipitation with stations-a new environmental record for monitoring extremes. Scientific Data, 2:150066.

Gao, J. and Mills, B. F. (2018). Weather Shocks, Coping Strategies, and Consumption Dynamics in Rural Ethiopia. World Development, 101:268-283.

Ghosh, M., Sarkar, D., and Roy, B. C., editors (2015). Diversification of Agriculture in Eastern India. India Studies in Business and Economics.

Heady, E. O. (1952). Diversification in Resource Allocation and Minimization of Income Variability. Journal of Farm Economics, 34(4):482-496.

Hirvonen, K. and Hoddinott, J. (2017). Agricultural production and children's diets: Evidence from rural Ethiopia. Agricultural Economics, 48(4):469-480.

Hoddinott, J., Headey, D., and Dereje, M. (2015). Cows, missing milk markets, and nutrition in rural Ethiopia. Journal of Development Studies, 51(8):958-975.

Imbs, J. and Wacziarg, R. (2003). Stages of diversification. American Economic Review, 93(1):63-86.

Jones, A. D., Shrinivas, A., and Bezner-Kerr, R. (2014). Farm production diversity is associated with greater household dietary diversity in Malawi: Findings from nationally representative data. Food Policy, 46(November):1-12.

Just, R. E. and Pope, R. D. (2001). The agricultural producer: Theory and statistical measurement. Handbook of Agricultural Economics, 1:629-741. 
Kasem, S. and Thapa, G. B. (2011). Crop diversification in Thailand: Status, determinants, and effects on income and use of inputs. Land Use Policy, 28(3):618-628.

Khanal, A. R. and Mishra, A. K. (2017). Enhancing food security: Food crop portfolio choice in response to climatic risk in India. Global Food Security, 12(July 2016):22-30.

Koppmair, S., Kassie, M., and Qaim, M. (2017). Farm production, market access and dietary diversity in Malawi. Public Health Nutrition, 20(2):325-335.

Krishnan, P. and Patnam, M. (2013). Neighbors and extension agents in Ethiopia: Who matters more for technology adoption? American Journal of Agricultural Economics, 96(1):308-327.

Kurosaki, T. and Fafchamps, M. (2002). Insurance market efficiency and crop choices in Pakistan. Journal of Development Economics, 67:419-453.

Lin, B. B. (2011). Resilience in Agriculture through Crop Diversification: Adaptive Management for Environmental Change. BioScience, 61(3):183-193.

Little, P. D., Smith, K., Cellarius, B. A., Coppock, D. L., and Barrett, C. (2001). Avoiding disaster: diversification and risk management among East African herders. Development and Change, 32(3):401-433.

Loison, S. A. (2015). Rural Livelihood Diversification in Sub-Saharan Africa: A Literature Review. Journal of Development Studies, 51(9):1125-1138.

Loreau, M. and Hector, A. (2001). Partitioning selection and complementarity in biodiversity experiments. Nature, 412:72-76.

Lovo, S. and Veronesi, M. (2019). Crop Diversification and Child Health: Empirical Evidence from Tanzania. Ecological Economics, 158:168-179.

Magnan, N., Spielman, D. J., Lybbert, T. J., and Gulati, K. (2015). Leveling with friends: Social networks and Indian farmers' demand for a technology with heterogeneous benefits. Journal of Development Economics, 116:223-251.

Makate, C., Wang, R., Makate, M., and Mango, N. (2016). Crop diversification and livelihoods of smallholder farmers in Zimbabwe: adaptive management for environmental change. SpringerPlus, 5(1):1135.

Massawe, F., Mayes, S., and Cheng, A. (2016). Crop Diversity: An Unexploited Treasure Trove for Food Security. Trends in Plant Science, 21(5):365-368.

Michler, J., Baylis, K., Arends-Kuenning, M., and Mazvimavi, K. (2018). Conservation Agriculture and Climate Resilience. Journal of Environmental Economics and Management, 93:148-169. 
Michler, J. D. and Balagtas, J. V. (2017). The Importance of the Savings Device in Precautionary Savings: Empirical Evidence from Rural Bangladesh. Agricultural Economics.

Michler, J. D. and Josephson, A. L. (2017). To Specialize or Diversify: Agricultural Diversity and Poverty Dynamics in Ethiopia. World Development, 89:214-226.

Morduch, J. (1995). Income Smoothing and Consumption Smoothing. Journal of Economic Perspectives, 9(3):103-114.

Mundlak, Y. (1978). On the Pooling of Times Series and Cross Section Data. Econometrica, 45(1):69-85.

Omamo, S. W. (1998). Farm-to-market transaction costs and specialisation in smallscale agriculture: Explorations with a non-separable household model. Journal of Development Studies, 35(2):152-163.

Papke, L. E. and Wooldridge, J. M. (2008). Panel data methods for fractional response variables with an application to test pass rates. Journal of Econometrics, 145(1-2):121133.

Pellegrini, L. and Tasciotti, L. (2014). Crop diversification, dietary diversity and agricultural income: empirical evidence from eight developing countries. Canadian Journal of Development Studies, 5189:211-227.

Pope, R. D. and Prescott, R. (1980). Diversification in Relation to Farm Size and Other Socioeconomic Characteristics. American Journal of Agricultural Economics, 62(3):554.

Rahman, S. and Chima, C. D. (2016). Determinants of Food Crop Diversity and Profitability in Southeastern Nigeria: A Multivariate Tobit Approach. Agriculture, 6(14).

Reardon, T. (1997). Using evidence of household income diversification to inform study of the rural nonfarm labor market in Africa. World Development, 25(5):735747 .

Romeo, A., Meerman, J., Demeke, M., Scognamillo, A., and Asfaw, S. (2016). Linking farm diversification to household diet diversification: Evidence from a sample of Kenyan ultra-poor farmers. Food Security, 8(6):1069-1085.

Rosenzweig, C. and Parry, M. L. (1994). Potential impact of climate change on world food supply. Nature, 367:133-138.

Rosenzweig, M. (1988). Risk, implicit contracts and the family in rural areas of lowincome countries. Economic Journal, 98(393):1148-1170. 
Bibliography

Rosenzweig, M. R. and Wolpin, K. I. (1993). Credit Market Constraints, Consumption Smoothing, and the Accumulation of Durable Production Assets in Low-Income Countries: Investments in Bullocks in India. Journal of Political Economy, 101(2):223244 .

Saenz, M. and Thompson, E. (2017). Gender and Policy Roles in Farm Household Diversification in Zambia. World Development, 89(2014):152-169.

Sala, O. E., Chapin, F. S., Armesto, J. J., Berlow, E., Bloomfield, J., Dirzo, R., HuberSanwald, E., Huenneke, L. F., Jackson, R. B., and Kinzig, A. (2000). Global biodiversity scenarios for the year 2100. Science, 287(5459):1770-1774.

Seo, S. N. and Mendelsohn, R. (2008). An analysis of crop choice: Adapting to climate change in south american farms. Ecological Economics, 67(1):109-116.

Sibhatu, K. T., Krishna, V. V., and Qaim, M. (2015). Production diversity and dietary diversity in smallholder farm households. Proceedings of the National Academy of Sciences, 2015(29):201510982.

Smale, M. (2006). Valuing Crop Biodiversity: On-farm Genetic Resources and Economic Change. Wallingford, UK: CABI Publishing.

Snapp, S. S. and Fisher, M. (2015). "Filling the maize basket" supports crop diversity and quality of household diet in Malawi. Food Security, 7:83-96.

Teklewold, H., Kassie, M., Shiferaw, B., and Köhlin, G. (2013). Cropping system diversification, conservation tillage and modern seed adoption in Ethiopia: Impacts on household income, agrochemical use and demand for labor. Ecological Economics, 93:85-93.

Terza, J. V., Basu, A., and Rathouz, P. J. (2008). Two-stage residual inclusion estimation: addressing endogeneity in health econometric modeling. Journal of Health Economics, 27(3):531-543.

Tilman, D., Polasky, S., and Lehman, C. (2005). Diversity, productivity and temporal stability in the economies of humans and nature. Journal of Environmental Economics and Management, 49(3):405-426.

Upton, J. B., Cissé, J. D., and Barrett, C. B. (2016). Food security as resilience: Reconciling definition and measurement. Agricultural Economics, 47(S1):135-147.

Van Dusen, M. E. and Taylor, J. E. (2005). Missing markets and crop diversity: Evidence from Mexico. Environment and Development Economics, 10(4):513-531.

Veljanoska, S. (2014). Agricultural Risk and Remittances: The case of Uganda. In 2014 International Congress, August 26-29, 2014, Ljubljana, Slovenia, number 182788. European Association of Agricultural Economists. 
Verkaart, S., Munyua, B. G., Mausch, K., and Michler, J. D. (2017). Welfare impacts of improved chickpea adoption: A pathway for rural development in Ethiopia? Food policy, 66:50-61.

White, H. (1980). A heteroskedasticity-consistent covariance matrix estimator and a direct test for heteroskedasticity. Econometrica: Journal of the Econometric Society, pages $817-838$.

Wooldridge, J. M. (2002). Simple solutions to the initial conditions problem in dynamic, nonlinear panel data models with unobserved heterogeneity.

Wooldridge, J. M. (2010). Econometric Analysis of Cross Section and Panel Data. London, England, second edition.

Wooldridge, J. M. (2014). Quasi-maximum likelihood estimation and testing for nonlinear models with endogenous explanatory variables. Journal of Econometrics, 182(1):226-234.

World Bank (2016). The Uganda Poverty Assessment Report 2016. Technical report, The World Bank Group. 


\section{APPENDIX}

Table B.1 Calculation of crop diversification indices

\begin{tabular}{llcc}
\hline \hline Index & Interpretation & Formula & Range \\
\hline Count & Richness & $\mathrm{D}=\mathrm{J}$ & $\mathrm{D} \geq 0$ \\
Shannon-Weaver & $\begin{array}{l}\text { Evenness; } \\
\text { proportional abundance }\end{array}$ & $D=-\sum_{i}^{\alpha} \alpha_{i} \ln \left(\alpha_{i}\right)$ & $\mathrm{D} \geq 0$ \\
Composite Entropy Index & $\begin{array}{l}\text { Evenness; } \\
\text { proportional abundance } \\
\text { Relative abundance }\end{array}$ & $D=-\sum_{i}^{\alpha} \alpha_{i} \ln \left(\alpha_{j}\right)(1-1 / J)$ & $\mathrm{O} \leq \mathrm{D} \leq 1$ \\
Berger-Parker & $\mathrm{D}=1 / \max \left(\alpha_{i}\right)$ & $\mathrm{D} \geq 1$ \\
\hline \hline
\end{tabular}

Note: $\alpha_{i}$ is the share of land allocated to the $i^{\text {th }}$ crop; J is the number of crops cultivated by the household. Source: Own elaboration based on Asfaw et al. (2018). 
Table B.2: Summary statistics for variables used in the analysis

\begin{tabular}{|c|c|c|c|c|}
\hline & $2009 / 10$ & $2010 / 11$ & $2011 / 12$ & Pooled \\
\hline \multirow[t]{2}{*}{ Age of head (years) } & 47.28 & 48.22 & 48.54 & 48.03 \\
\hline & $(14.92)$ & (15.03) & $(15.24)$ & $(15.08)$ \\
\hline \multirow[t]{2}{*}{ Male headed } & 0.744 & 0.729 & 0.713 & 0.728 \\
\hline & $(0.437)$ & $(0.445)$ & $(0.452)$ & $(0.445)$ \\
\hline \multirow[t]{2}{*}{ Household size } & 4.667 & 4.391 & $4 \cdot 312$ & $4 \cdot 452$ \\
\hline & $(2.066)$ & $(1.902)$ & (1.979) & $(1.990)$ \\
\hline \multirow[t]{2}{*}{ Head education } & 0.193 & 0.328 & 0.304 & 0.275 \\
\hline & $(0.395)$ & $(0.470)$ & $(0.460)$ & $(0.446)$ \\
\hline \multirow[t]{2}{*}{ Asset value (X1000) } & 13362.5 & 14552.3 & 14490.0 & 14140.2 \\
\hline & $(39676.3)$ & $(44866.6)$ & $(39295.0)$ & $(41172.8)$ \\
\hline \multirow[t]{2}{*}{ Land cultivated (acres) } & $4 \cdot 746$ & 5.257 & $3 \cdot 545$ & 4.455 \\
\hline & $(22.84)$ & $(27.65)$ & $(6.530)$ & $(20.44)$ \\
\hline \multirow[t]{2}{*}{ Livestock holding (TLU) } & 2.262 & 1.908 & 1.868 & 2.009 \\
\hline & (3.994) & $(3.436)$ & $(3.710)$ & $(3.730)$ \\
\hline \multirow[t]{2}{*}{ Remittances ( $1=$ Yes) } & 0.283 & 0.277 & 0.279 & 0.280 \\
\hline & $(0.450)$ & $(0.448)$ & (o.449) & (o.449) \\
\hline \multirow[t]{2}{*}{ Distance to road (Km) } & 8.798 & 8.853 & 8.745 & 8.795 \\
\hline & $(7.175)$ & $(7.246)$ & $(7.189)$ & $(7.200)$ \\
\hline \multirow[t]{2}{*}{ Distance to market $(\mathrm{Km})$} & 33.64 & $33 \cdot 36$ & $33 \cdot 58$ & $33 \cdot 53$ \\
\hline & $(17.94)$ & $(17.62)$ & $(18.60)$ & (18.09) \\
\hline \multirow[t]{2}{*}{ Production shock $(1=$ Yes $)$} & 0.596 & 0.390 & 0.315 & 0.429 \\
\hline & (o.491) & (o.488) & $(0.465)$ & (o.495) \\
\hline \multirow[t]{2}{*}{ Health shock ( $1=$ Yes) } & 0.165 & 0.133 & 0.067 & 0.119 \\
\hline & $(0.371)$ & $(0.340)$ & $(0.250)$ & $(0.324)$ \\
\hline \multirow[t]{2}{*}{ High cost of inputs ( $1=$ Yes) } & 0.0257 & 0.0125 & 0.0137 & 0.0173 \\
\hline & $(0.158)$ & (0.111) & $(0.116)$ & (0.130) \\
\hline \multirow[t]{2}{*}{ Rainfall shock } & 1.271 & 0.106 & 0.000280 & 0.448 \\
\hline & (o.877) & $(0.240)$ & $(0.00432)$ & $(0.775)$ \\
\hline \multirow[t]{2}{*}{ Mean temperature $\left({ }^{\circ} \mathrm{C}\right)$} & 21.66 & 21.69 & 21.64 & 21.66 \\
\hline & $(1.588)$ & $(1.577)$ & (1.649) & $(1.607)$ \\
\hline \multirow[t]{2}{*}{ Elevation (Km) } & 1.234 & 1.232 & 1.236 & 1.234 \\
\hline & $(0.247)$ & $(0.247)$ & $(0.260)$ & $(0.252)$ \\
\hline Observations & 1,479 & 1,367 & 1,677 & 4,523 \\
\hline
\end{tabular}

Note: Mean values reported, standard deviations in parentheses. 
Table B.3: Effect of crop diversity on dietary diversity: FE-IV estimates

\begin{tabular}{|c|c|c|c|c|}
\hline & Count index & Shannon-Weaver & Composite Entropy & Berger-Parker \\
\hline \multirow[t]{2}{*}{ Crop diversity } & $0.158^{* *}$ & $1.317^{* * *}$ & $4.682^{* * *}$ & $0.648^{* * *}$ \\
\hline & $(0.075)$ & $(0.418)$ & $(1.624)$ & $(0.210)$ \\
\hline \multirow[t]{2}{*}{ Age of head } & $-0.019^{*}$ & $-0.021^{* *}$ & $-0.021^{* *}$ & $-0.021^{* *}$ \\
\hline & $(0.011)$ & (0.010) & (0.010) & $(0.011)$ \\
\hline \multirow[t]{2}{*}{ Male headed } & -0.070 & -0.105 & -0.147 & -0.142 \\
\hline & $(0.246)$ & $(0.246)$ & $(0.250)$ & $(0.262)$ \\
\hline \multirow[t]{2}{*}{ Household size } & $0.100^{* * *}$ & $0.096^{* *}$ & $0.094^{* *}$ & $0.096^{* *}$ \\
\hline & $(0.038)$ & $(0.038)$ & $(0.038)$ & (0.039) \\
\hline \multirow[t]{2}{*}{ Head education } & $0.303^{* *}$ & $0.268^{* *}$ & $0.256^{* *}$ & $0.28 \mathrm{o}^{* *}$ \\
\hline & $(0.122)$ & $(0.122)$ & $(0.124)$ & $(0.124)$ \\
\hline \multirow[t]{2}{*}{ Asset value (log) } & $0.048^{* *}$ & $0.044^{* *}$ & $0.044^{*}$ & $0.057^{* *}$ \\
\hline & $(0.021)$ & $(0.022)$ & $(0.023)$ & $(0.023)$ \\
\hline \multirow[t]{2}{*}{ Land size (log) } & 0.063 & 0.043 & 0.056 & 0.051 \\
\hline & (o.049) & (o.049) & (o.049) & $(0.050)$ \\
\hline \multirow[t]{2}{*}{ Livestock holding } & 0.017 & 0.011 & 0.007 & 0.011 \\
\hline & $(0.018)$ & $(0.018)$ & (0.018) & (0.018) \\
\hline \multirow[t]{2}{*}{ Remittances } & 0.066 & 0.063 & 0.053 & 0.068 \\
\hline & (0.089) & (0.091) & (0.093) & $(0.092)$ \\
\hline \multirow[t]{2}{*}{ Distance to road } & -0.042 & -0.043 & -0.041 & -0.056 \\
\hline & $(0.046)$ & $(0.049)$ & (0.054) & $(0.052)$ \\
\hline \multirow[t]{2}{*}{ Distance to market } & -0.014 & -0.023 & -0.030 & -0.011 \\
\hline & $(0.027)$ & (0.029) & $(0.032)$ & (0.030) \\
\hline \multirow[t]{2}{*}{ Constant } & $6.929^{* * *}$ & $6.540^{* * *}$ & $5 \cdot 531^{* * *}$ & $6.141^{* * *}$ \\
\hline & $(0.996)$ & $(1.026)$ & $(1.218)$ & $(1.139)$ \\
\hline Year & Yes & Yes & Yes & Yes \\
\hline F test of excluded instruments & $33.29^{* * *}$ & $24.06^{* * *}$ & $10.89^{* * *}$ & $11.31^{* * *}$ \\
\hline Kleibergen-Paap Wald F statistic & $33.29^{* *}$ & $24.06^{* *}$ & $10.89^{* *}$ & $11 \cdot 31^{* *}$ \\
\hline Sargan-Hansen (Hansen J) statistic & $7 \cdot 306$ & 7.028 & $4 \cdot 791$ & 7.258 \\
\hline Observations & 4523 & 4523 & 4523 & 4521 \\
\hline
\end{tabular}

Note: ${ }^{*} p<0.10,{ }^{* *} p<0.05,{ }^{* * *} p<0.01$; clustered standard errors in parentheses. In all models crop diversity is treated as endogenous and instrumented with the rainfall shock, elevation-temperature interaction and village level crop diversity. Kleibergen-Paap Wald F statistic is for weak identification test. Sargan-Hansen (Hansen J) is for overidentification test of all instruments. 
Table B.4: Effects of crop diversity on dietary diversity: 2SRI estimates

\begin{tabular}{|c|c|c|c|c|}
\hline & Count Index & Shannon-Weaver & Composite Entropy & Berger-Parker \\
\hline \multirow[t]{2}{*}{ Crop diversity } & $0.104^{*}$ & $0.976^{* * *}$ & $2.538^{* * *}$ & $0.352^{* * *}$ \\
\hline & (0.06o) & $(0.305)$ & $(0.978)$ & (0.118) \\
\hline \multirow[t]{2}{*}{ Generalized residual } & -0.051 & $-0.674^{* *}$ & $-1.781^{*}$ & $-0.285^{* *}$ \\
\hline & $(0.064)$ & (o.319) & $(0.998)$ & (0.121) \\
\hline \multirow[t]{2}{*}{ Age of head } & $-0.015^{*}$ & $-0.016^{*}$ & -0.015 & -0.015 \\
\hline & (o.009) & (o.009) & (o.0o9) & (o.0o9) \\
\hline \multirow[t]{2}{*}{ Male headed } & -0.147 & -0.163 & -0.216 & -0.201 \\
\hline & (o.219) & $(0.217)$ & $(0.217)$ & (o.219) \\
\hline \multirow[t]{2}{*}{ Household size } & $0.100^{* * *}$ & $0.096^{* * *}$ & $0.098^{* * *}$ & $0.096^{* * *}$ \\
\hline & $(0.036)$ & (o.035) & (o.035) & (o.035) \\
\hline \multirow[t]{2}{*}{ Head education } & $0.328^{* * *}$ & $0.304^{* * *}$ & $0.310^{* * *}$ & $0.324^{* * *}$ \\
\hline & (0.115) & (0.115) & (o.116) & (0.114) \\
\hline \multirow[t]{2}{*}{ Asset value (log) } & $0.064^{* * *}$ & $0.064^{* * *}$ & $0.068^{* * *}$ & $0.073^{* * *}$ \\
\hline & $(0.022)$ & (0.022) & (0.023) & (0.023) \\
\hline \multirow[t]{2}{*}{ Land size (log) } & $0.095^{* *}$ & $0.079^{*}$ & $0.098^{* *}$ & $0.096^{* *}$ \\
\hline & (0.047) & (0.047) & $(0.046)$ & $(0.046)$ \\
\hline \multirow[t]{2}{*}{ Livestock holding } & 0.017 & 0.013 & 0.010 & 0.013 \\
\hline & (o.018) & (0.018) & (0.019) & (o.019) \\
\hline \multirow[t]{2}{*}{ Remittances } & 0.034 & 0.033 & 0.029 & 0.030 \\
\hline & (o.o86) & (o.o86) & (o.o87) & $(0.087)$ \\
\hline \multirow[t]{2}{*}{ Distance to road } & -0.061 & -0.060 & -0.056 & -0.061 \\
\hline & $(0.047)$ & $(0.048)$ & (o.049) & (o.049) \\
\hline \multirow[t]{2}{*}{ Distance to market } & -0.006 & -0.016 & -0.017 & -0.011 \\
\hline & $(0.020)$ & (0.020) & $(0.020)$ & $(0.020)$ \\
\hline \multirow[t]{2}{*}{ Constant } & $2.846^{* * *}$ & $2.746^{* * *}$ & $2.572^{* * *}$ & $2.905^{* * *}$ \\
\hline & $(0.581)$ & (o.6o3) & $(0.723)$ & (o.656) \\
\hline Mundlak variables & Yes & Yes & Yes & Yes \\
\hline Region & Yes & Yes & Yes & Yes \\
\hline Year & Yes & Yes & Yes & Yes \\
\hline \multirow[t]{2}{*}{ Constant } & $2.846^{* * *}$ & $2.746^{* * *}$ & $2.572^{* * *}$ & $2.905^{* * *}$ \\
\hline & $(0.561)$ & $(0.584)$ & (o.695) & (o.640) \\
\hline Observations & 4520 & 4520 & 4520 & 4518 \\
\hline$\chi^{2}$ & $867.99^{* * *}$ & $780.51^{* * *}$ & $737.64^{* * *}$ & $733.80^{* * *}$ \\
\hline
\end{tabular}

Note: Bootstrapped (500 replications) and clustered standard errors in parentheses. ${ }^{*} p<0.10$, ${ }^{* *} p<$ $0.05,{ }^{* * *} p<0.01$; All regressions include time averages of time varying variables and the generalized residuals. 
Table B.5: Effects of crop diversity on consumption expenditure: FE-IV estimates

\begin{tabular}{|c|c|c|c|c|}
\hline & Count index & Shannon-Weaver & Composite Entropy & Berger-Parker \\
\hline \multirow[t]{2}{*}{ Crop diversity } & $0.045^{* *}$ & $0.256^{* *}$ & $0.763^{*}$ & $0.132^{* *}$ \\
\hline & $(0.020)$ & (0.108) & $(0.403)$ & $(0.055)$ \\
\hline \multirow[t]{2}{*}{ Age of head } & $0.007^{* *}$ & $0.007^{* *}$ & $0.007^{* *}$ & $0.007^{*}$ \\
\hline & $(0.003)$ & (0.003) & (0.003) & (0.003) \\
\hline \multirow[t]{2}{*}{ Male headed } & -0.022 & -0.033 & -0.040 & -0.041 \\
\hline & $(0.072)$ & $(0.071)$ & $(0.071)$ & $(0.072)$ \\
\hline \multirow[t]{2}{*}{ Household size } & $-0.141^{* * *}$ & $-0.142^{* * *}$ & $-0.142^{* * *}$ & $-0.141^{* * *}$ \\
\hline & (0.010) & (0.010) & (0.010) & $(0.011)$ \\
\hline \multirow[t]{2}{*}{ Head education } & 0.009 & 0.004 & 0.004 & 0.006 \\
\hline & (0.029) & (o.029) & $(0.029)$ & $(0.029)$ \\
\hline \multirow[t]{2}{*}{ Asset value (log) } & $0.033^{* * *}$ & $0.033^{* * *}$ & $0.033^{* * *}$ & $0.035^{* * *}$ \\
\hline & (o.007) & $(0.007)$ & (0.007) & $(0.007)$ \\
\hline \multirow[t]{2}{*}{ Land size (log) } & $0.038^{* * *}$ & $0.038^{* * *}$ & $0.042^{* * *}$ & $0.039^{* * *}$ \\
\hline & (0.013) & (0.014) & (0.013) & (0.014) \\
\hline \multirow[t]{2}{*}{ Livestock holding } & 0.003 & 0.002 & 0.001 & 0.002 \\
\hline & (0.005) & (0.005) & (0.005) & (0.005) \\
\hline \multirow[t]{2}{*}{ Remittances } & 0.007 & 0.006 & 0.005 & 0.008 \\
\hline & $(0.025)$ & $(0.025)$ & $(0.025)$ & $(0.026)$ \\
\hline \multirow[t]{2}{*}{ Distance to road } & -0.010 & -0.010 & -0.010 & -0.013 \\
\hline & (o.009) & (o.0og) & (0.010) & (0.010) \\
\hline \multirow[t]{2}{*}{ Distance to market } & 0.003 & 0.002 & 0.002 & 0.005 \\
\hline & (o.0o6) & (o.0o6) & (o.oo6) & $(0.006)$ \\
\hline \multirow[t]{2}{*}{ Constant } & $10.183^{* * *}$ & $10.143^{* * *}$ & $10.004^{* * *}$ & $10.056^{* * *}$ \\
\hline & $(0.270)$ & $(0.270)$ & $(0.302)$ & $(0.285)$ \\
\hline Year & Yes & Yes & Yes & Yes \\
\hline F test of excluded instruments & $33.29^{* * * *}$ & $24.06^{* * *}$ & $10.89 * * *$ & $11 \cdot 31^{* * *}$ \\
\hline Kleibergen-Paap Wald F statistic & $33.29^{* *}$ & $24.06^{* *}$ & $10.89^{*}$ & $11.31^{*}$ \\
\hline Sargan-Hansen statistic & 3.22 & 3.22 & 3.49 & 3.33 \\
\hline Observations & 4523 & 4523 & 4523 & 4521 \\
\hline
\end{tabular}

Note: Bootstrapped standard errors (500 replications) in parentheses. ${ }^{*} p<0.10,{ }^{* *} p<0.05,{ }^{* * *} p<0.01$; All regressions include time averages of time varying variables. 
Table B.6: Consumption expenditure effects of crop diversity: 2SRI estimates

\begin{tabular}{|c|c|c|c|c|}
\hline & Count index & Shannon-Weaver & Composite Entropy & Berger-Parker \\
\hline Crop diversity & $\begin{array}{l}0.039^{* *} \\
(0.015)\end{array}$ & $\begin{array}{l}0.215^{* * *} \\
(0.081)\end{array}$ & $\begin{array}{c}0.426 \\
(0.267)\end{array}$ & $\begin{array}{c}0.055 \\
(0.035)\end{array}$ \\
\hline Generalized residual & $\begin{array}{l}-0.027^{*} \\
(0.015)\end{array}$ & $\begin{array}{l}-0.183^{* *} \\
(0.083)\end{array}$ & $\begin{array}{l}-0.379 \\
(0.276)\end{array}$ & $\begin{array}{l}-0.046 \\
(0.035)\end{array}$ \\
\hline Age of head & $\begin{array}{l}0.006^{* *} \\
(0.003)\end{array}$ & $\begin{array}{l}0.007^{* *} \\
(0.003)\end{array}$ & $\begin{array}{l}0.007^{* *} \\
(0.003)\end{array}$ & $\begin{array}{l}0.007^{* *} \\
(0.003)\end{array}$ \\
\hline Male headed & $\begin{array}{l}-0.022 \\
(0.066)\end{array}$ & $\begin{array}{l}-0.036 \\
(0.065)\end{array}$ & $\begin{array}{l}-0.047 \\
(0.065)\end{array}$ & $\begin{array}{l}-0.044 \\
(0.065)\end{array}$ \\
\hline Household size & $\begin{array}{c}-0.145^{* * *} \\
(0.010)\end{array}$ & $\begin{array}{c}-0.145^{* * *} \\
(0.010)\end{array}$ & $\begin{array}{c}-0.145^{* * *} \\
(0.010)\end{array}$ & $\begin{array}{c}-0.145^{* * *} \\
(0.010)\end{array}$ \\
\hline Head education & $\begin{array}{c}0.018 \\
(0.029)\end{array}$ & $\begin{array}{c}0.014 \\
(0.029)\end{array}$ & $\begin{array}{c}0.017 \\
(0.029)\end{array}$ & $\begin{array}{c}0.020 \\
(0.029)\end{array}$ \\
\hline Asset value (log) & $\begin{array}{l}0.050^{* * *} \\
(0.009)\end{array}$ & $\begin{array}{l}0.051^{* * *} \\
(0.009)\end{array}$ & $\begin{array}{l}0.052^{* * *} \\
(0.009)\end{array}$ & $\begin{array}{l}0.052^{* * *} \\
(0.009)\end{array}$ \\
\hline Land size (log) & $\begin{array}{l}0.037^{* * *} \\
(0.013)\end{array}$ & $\begin{array}{l}0.038^{* * *} \\
(0.013)\end{array}$ & $\begin{array}{l}0.043^{* * *} \\
(0.012)\end{array}$ & $\begin{array}{l}0.043^{* * *} \\
(0.012)\end{array}$ \\
\hline Livestock holding & $\begin{array}{c}0.002 \\
(0.005)\end{array}$ & $\begin{array}{c}0.001 \\
(0.005)\end{array}$ & $\begin{array}{c}0.001 \\
(0.005)\end{array}$ & $\begin{array}{c}0.001 \\
(0.005)\end{array}$ \\
\hline Remittances & $\begin{array}{c}0.002 \\
(0.024)\end{array}$ & $\begin{array}{c}0.002 \\
(0.024)\end{array}$ & $\begin{array}{c}0.001 \\
(0.024)\end{array}$ & $\begin{array}{c}0.001 \\
(0.024)\end{array}$ \\
\hline Distance to road & $\begin{array}{l}-0.008 \\
(0.014)\end{array}$ & $\begin{array}{l}-0.007 \\
(0.014)\end{array}$ & $\begin{array}{l}-0.007 \\
(0.014)\end{array}$ & $\begin{array}{l}-0.008 \\
(0.014)\end{array}$ \\
\hline Distance to market & $\begin{array}{l}-0.001 \\
(0.005)\end{array}$ & $\begin{array}{l}-0.003 \\
(0.005)\end{array}$ & $\begin{array}{l}-0.002 \\
(0.006)\end{array}$ & $\begin{array}{l}-0.000 \\
(0.005)\end{array}$ \\
\hline Mundlak variables & Yes & Yes & Yes & Yes \\
\hline Region & Yes & Yes & Yes & Yes \\
\hline Year & Yes & Yes & Yes & Yes \\
\hline Constant & $\begin{array}{l}9.091^{* * *} \\
(0.190)\end{array}$ & $\begin{array}{l}9.158^{* * *} \\
(0.194)\end{array}$ & $\begin{array}{l}9.282^{* * *} \\
(0.217)\end{array}$ & $\begin{array}{l}9.246^{* * *} \\
(0.202)\end{array}$ \\
\hline $\begin{array}{l}\text { Observations } \\
\chi^{2}\end{array}$ & $\begin{array}{c}4520 \\
1673 \cdot 53^{* * *}\end{array}$ & $\begin{array}{c}4520 \\
1643.92^{* * *}\end{array}$ & $\begin{array}{c}4520 \\
1667.61^{* * *}\end{array}$ & $\begin{array}{c}4518 \\
1666.18^{* * *}\end{array}$ \\
\hline
\end{tabular}

Note: Bootstrapped standard errors (50o replications) in parentheses. ${ }^{*} p<0.10,{ }^{* *} p<0.05,{ }^{* * *} p<0.01$; All regressions include time averages of time varying variables. 
Table B.7: Welfare effects of crop diversity (Count index): Quantile regression estimates

\begin{tabular}{|c|c|c|c|c|}
\hline & $Q=20 \%$ & $Q=40 \%$ & $\mathrm{Q}=60 \%$ & $\mathrm{Q}=80 \%$ \\
\hline Count index & $\begin{array}{c}0.112^{* * *} \\
(0.026)\end{array}$ & $\begin{array}{c}0.094^{* * *} \\
(0.022)\end{array}$ & $\begin{array}{c}0.082^{* * *} \\
(0.021)\end{array}$ & $\begin{array}{c}0.080^{* * *} \\
(0.020)\end{array}$ \\
\hline Generalized residual & $\begin{array}{c}-0.104^{* * *} \\
(0.026)\end{array}$ & $\begin{array}{c}-0.086^{* * *} \\
(0.024)\end{array}$ & $\begin{array}{c}-0.075^{* * *} \\
(0.023)\end{array}$ & $\begin{array}{c}-0.074^{* * *} \\
(0.022)\end{array}$ \\
\hline Age of head & $\begin{array}{c}0.002 \\
(0.005)\end{array}$ & $\begin{array}{c}0.004 \\
(0.005)\end{array}$ & $\begin{array}{c}0.003 \\
(0.004)\end{array}$ & $\begin{array}{l}0.007^{*} \\
(0.004)\end{array}$ \\
\hline Male headed & $\begin{array}{l}-0.058 \\
(0.130)\end{array}$ & $\begin{array}{c}0.075 \\
(0.108)\end{array}$ & $\begin{array}{l}-0.007 \\
(0.097)\end{array}$ & $\begin{array}{c}0.046 \\
(0.112)\end{array}$ \\
\hline Household size & $\begin{array}{c}-0.143^{* * *} \\
(0.018)\end{array}$ & $\begin{array}{c}-0.145^{* * *} \\
(0.014)\end{array}$ & $\begin{array}{c}-0.144^{* * *} \\
(0.015)\end{array}$ & $\begin{array}{c}-0.157^{* * *} \\
(0.017)\end{array}$ \\
\hline Head education & $\begin{array}{l}-0.009 \\
(0.057)\end{array}$ & $\begin{array}{c}0.049 \\
(0.054)\end{array}$ & $\begin{array}{c}0.008 \\
(0.050)\end{array}$ & $\begin{array}{c}0.002 \\
(0.052)\end{array}$ \\
\hline Asset value (log) & $\begin{array}{c}0.089^{* * *} \\
(0.017)\end{array}$ & $\begin{array}{c}0.090^{* * *} \\
(0.014)\end{array}$ & $\begin{array}{c}0.080^{* * *} \\
(0.014)\end{array}$ & $\begin{array}{c}0.073^{* * *} \\
(0.018)\end{array}$ \\
\hline Land size (log) & $\begin{array}{c}0.014 \\
(0.018)\end{array}$ & $\begin{array}{c}0.023 \\
(0.017)\end{array}$ & $\begin{array}{l}0.034^{*} \\
(0.018)\end{array}$ & $\begin{array}{c}0.014 \\
(0.021)\end{array}$ \\
\hline Livestock holding & $\begin{array}{c}0.011 \\
(0.010)\end{array}$ & $\begin{array}{c}0.005 \\
(0.008)\end{array}$ & $\begin{array}{c}0.007 \\
(0.008)\end{array}$ & $\begin{array}{c}0.007 \\
(0.008)\end{array}$ \\
\hline Remittances & $\begin{array}{c}0.040 \\
(0.043)\end{array}$ & $\begin{array}{c}0.024 \\
(0.033)\end{array}$ & $\begin{array}{l}-0.003 \\
(0.031)\end{array}$ & $\begin{array}{l}-0.040 \\
(0.038)\end{array}$ \\
\hline Distance to road & $\begin{array}{l}-0.014 \\
(0.018)\end{array}$ & $\begin{array}{l}-0.020 \\
(0.012)\end{array}$ & $\begin{array}{l}-0.008 \\
(0.010)\end{array}$ & $\begin{array}{l}-0.002 \\
(0.018)\end{array}$ \\
\hline Distance to market & $\begin{array}{l}-0.015 \\
(0.012)\end{array}$ & $\begin{array}{c}0.001 \\
(0.006)\end{array}$ & $\begin{array}{l}-0.001 \\
(0.004)\end{array}$ & $\begin{array}{c}0.007 \\
(0.010)\end{array}$ \\
\hline Mundlak variables & Yes & Yes & Yes & Yes \\
\hline Year & Yes & Yes & Yes & Yes \\
\hline Constant & $\begin{array}{c}7 \cdot 399^{* * *} \\
(0.256)\end{array}$ & $\begin{array}{c}7.866^{* * *} \\
(0.182)\end{array}$ & $\begin{array}{c}8.403^{* * *} \\
(0.178)\end{array}$ & $\begin{array}{c}8.994^{* * *} \\
(0.225)\end{array}$ \\
\hline Observations & 4520 & 4520 & 4520 & 4520 \\
\hline
\end{tabular}

Note: Dependent variable is real consumption expenditure per adult equivalent. The variable is log transformed and valued in Ugandan Shillings. Bootstrapped standard errors in parentheses with 500 replications; ${ }^{*} p<0.10,{ }^{* *} p<0.05,{ }^{* * *} p<0.01$; All regressions include control variables, time averages of time varying variables, and year dummy. 
Table B.8: Welfare effects of crop diversity (Shannon-Weaver): Quantile regression estimates

\begin{tabular}{|c|c|c|c|c|}
\hline & $Q=20 \%$ & $Q=40 \%$ & $\mathrm{Q}=60 \%$ & $\mathrm{Q}=80 \%$ \\
\hline Shannon-Weaver & $\begin{array}{c}0.423^{* * *} \\
(0.140)\end{array}$ & $\begin{array}{c}0.382^{* * *} \\
(0.123)\end{array}$ & $\begin{array}{l}0.247^{* *} \\
(0.107)\end{array}$ & $\begin{array}{l}0.231^{* *} \\
(0.113)\end{array}$ \\
\hline Generalized residual & $\begin{array}{c}-0.377^{* *} \\
(0.151)\end{array}$ & $\begin{array}{l}-0.355^{* *} \\
(0.139)\end{array}$ & $\begin{array}{l}-0.221^{*} \\
(0.115)\end{array}$ & $\begin{array}{c}-0.238^{* *} \\
(0.122)\end{array}$ \\
\hline Age of head & $\begin{array}{c}0.003 \\
(0.005)\end{array}$ & $\begin{array}{c}0.002 \\
(0.004)\end{array}$ & $\begin{array}{c}0.006 \\
(0.004)\end{array}$ & $\begin{array}{l}0.011^{* *} \\
(0.004)\end{array}$ \\
\hline Male headed & $\begin{array}{l}-0.070 \\
(0.121)\end{array}$ & $\begin{array}{c}0.018 \\
(0.107)\end{array}$ & $\begin{array}{l}-0.087 \\
(0.093)\end{array}$ & $\begin{array}{c}0.021 \\
(0.111)\end{array}$ \\
\hline Household size & $\begin{array}{c}-0.129^{* * *} \\
(0.017)\end{array}$ & $\begin{array}{c}-0.146^{* * *} \\
(0.014)\end{array}$ & $\begin{array}{c}-0.151^{* * *} \\
(0.014)\end{array}$ & $\begin{array}{c}-0.167^{* * *} \\
(0.018)\end{array}$ \\
\hline Head education & $\begin{array}{l}-0.009 \\
(0.064)\end{array}$ & $\begin{array}{c}0.022 \\
(0.053)\end{array}$ & $\begin{array}{c}0.025 \\
(0.048)\end{array}$ & $\begin{array}{c}0.003 \\
(0.050)\end{array}$ \\
\hline Asset value (log) & $\begin{array}{c}0.088^{* * *} \\
(0.018)\end{array}$ & $\begin{array}{c}0.093^{* * *} \\
(0.013)\end{array}$ & $\begin{array}{c}0.089^{* * *} \\
(0.015)\end{array}$ & $\begin{array}{c}0.075^{* * *} \\
(0.018)\end{array}$ \\
\hline Land size (log) & $\begin{array}{c}0.023 \\
(0.019)\end{array}$ & $\begin{array}{l}0.039^{* *} \\
(0.017)\end{array}$ & $\begin{array}{c}0.056^{* * *} \\
(0.020)\end{array}$ & $\begin{array}{l}0.036^{*} \\
(0.020)\end{array}$ \\
\hline Livestock holding & $\begin{array}{c}0.007 \\
(0.010)\end{array}$ & $\begin{array}{l}-0.001 \\
(0.008)\end{array}$ & $\begin{array}{c}0.006 \\
(0.006)\end{array}$ & $\begin{array}{c}0.006 \\
(0.009)\end{array}$ \\
\hline Remittances & $\begin{array}{c}0.048 \\
(0.044)\end{array}$ & $\begin{array}{c}0.033 \\
(0.036)\end{array}$ & $\begin{array}{l}-0.004 \\
(0.032)\end{array}$ & $\begin{array}{l}-0.055 \\
(0.042)\end{array}$ \\
\hline Distance to road & $\begin{array}{l}-0.010 \\
(0.016)\end{array}$ & $\begin{array}{l}-0.010 \\
(0.014)\end{array}$ & $\begin{array}{l}-0.013 \\
(0.012)\end{array}$ & $\begin{array}{l}-0.001 \\
(0.022)\end{array}$ \\
\hline Distance to market & $\begin{array}{l}-0.015 \\
(0.010)\end{array}$ & $\begin{array}{l}-0.008 \\
(0.005)\end{array}$ & $\begin{array}{c}0.001 \\
(0.005)\end{array}$ & $\begin{array}{c}0.009 \\
(0.012)\end{array}$ \\
\hline Mundlak variables & Yes & Yes & Yes & Yes \\
\hline Year & Yes & Yes & Yes & Yes \\
\hline Constant & $\begin{array}{c}7.035^{* * *} \\
(0.234)\end{array}$ & $\begin{array}{l}7.814^{* * *} \\
(0.202)\end{array}$ & $\begin{array}{c}8.326^{* * *} \\
(0.209)\end{array}$ & $\begin{array}{c}9.045^{* * *} \\
(0.244)\end{array}$ \\
\hline Observations & 4520 & 4520 & 4520 & 4520 \\
\hline
\end{tabular}

Note: Dependent variable is real consumption expenditure per adult equivalent. The variable is log transformed and valued in Ugandan Shillings. Bootstrapped standard errors in parentheses with 500 replications; ${ }^{*} p<0.10,{ }^{* *} p<0.05,{ }^{* * *} p<0.01$; All regressions include control variables, time averages of time varying variables, and year dummy. 
Table B.9: Welfare effects of crop diversity (Composite entropy): Quantile regression estimates

\begin{tabular}{|c|c|c|c|c|}
\hline & $Q=20 \%$ & $\mathrm{Q}=40 \%$ & $\mathrm{Q}=60 \%$ & $\mathrm{Q}=80 \%$ \\
\hline Composite entropy & $\begin{array}{c}0.396 \\
(0.388)\end{array}$ & $\begin{array}{c}0.198 \\
(0.426)\end{array}$ & $\begin{array}{l}-0.231 \\
(0.296)\end{array}$ & $\begin{array}{l}-0.026 \\
(0.333)\end{array}$ \\
\hline Generalized residual & $\begin{array}{l}-0.252 \\
(0.414)\end{array}$ & $\begin{array}{l}-0.139 \\
(0.451)\end{array}$ & $\begin{array}{c}0.236 \\
(0.315)\end{array}$ & $\begin{array}{l}-0.069 \\
(0.364)\end{array}$ \\
\hline Age of head & $\begin{array}{c}0.005 \\
(0.005)\end{array}$ & $\begin{array}{c}0.004 \\
(0.004)\end{array}$ & $\begin{array}{l}0.008^{* *} \\
(0.003)\end{array}$ & $\begin{array}{c}0.011^{* * *} \\
(0.004)\end{array}$ \\
\hline Male headed & $\begin{array}{l}-0.070 \\
(0.136)\end{array}$ & $\begin{array}{l}-0.038 \\
(0.101)\end{array}$ & $\begin{array}{l}-0.094 \\
\text { (0.101) }\end{array}$ & $\begin{array}{l}-0.061 \\
(0.101)\end{array}$ \\
\hline Household size & $\begin{array}{c}-0.133^{* * *} \\
(0.018)\end{array}$ & $\begin{array}{c}-0.147^{* * *} \\
(0.014)\end{array}$ & $\begin{array}{c}-0.149^{* * *} \\
(0.015)\end{array}$ & $\begin{array}{c}-0.162^{* * *} \\
(0.018)\end{array}$ \\
\hline Head education & $\begin{array}{l}-0.008 \\
(0.058)\end{array}$ & $\begin{array}{c}0.012 \\
(0.053)\end{array}$ & $\begin{array}{c}0.047 \\
(0.048)\end{array}$ & $\begin{array}{c}0.021 \\
(0.053)\end{array}$ \\
\hline Asset value (log) & $\begin{array}{c}0.102^{* * *} \\
(0.019)\end{array}$ & $\begin{array}{c}0.094^{* * *} \\
(0.013)\end{array}$ & $\begin{array}{c}0.090^{* * *} \\
(0.015)\end{array}$ & $\begin{array}{c}0.077^{* * *} \\
(0.018)\end{array}$ \\
\hline Land size (log) & $\begin{array}{c}0.025 \\
(0.019)\end{array}$ & $\begin{array}{c}0.056^{* * *} \\
(0.018)\end{array}$ & $\begin{array}{c}0.069^{* * *} \\
(0.018)\end{array}$ & $\begin{array}{l}0.044^{*} \\
(0.023)\end{array}$ \\
\hline Livestock holding & $\begin{array}{c}0.006 \\
(0.009)\end{array}$ & $\begin{array}{l}-0.002 \\
(0.008)\end{array}$ & $\begin{array}{c}0.008 \\
(0.006)\end{array}$ & $\begin{array}{c}0.009 \\
(0.008)\end{array}$ \\
\hline Remittances & $\begin{array}{c}0.051 \\
(0.042)\end{array}$ & $\begin{array}{c}0.023 \\
(0.036)\end{array}$ & $\begin{array}{l}-0.017 \\
(0.031)\end{array}$ & $\begin{array}{l}-0.065 \\
(0.045)\end{array}$ \\
\hline Distance to road & $\begin{array}{l}-0.012 \\
(0.017)\end{array}$ & $\begin{array}{l}-0.010 \\
(0.013)\end{array}$ & $\begin{array}{l}-0.015 \\
(0.012)\end{array}$ & $\begin{array}{l}-0.004 \\
(0.022)\end{array}$ \\
\hline Distance to market & $\begin{array}{l}-0.011 \\
(0.008)\end{array}$ & $\begin{array}{l}-0.000 \\
(0.007)\end{array}$ & $\begin{array}{c}0.008 \\
(0.006)\end{array}$ & $\begin{array}{c}0.016 \\
(0.013)\end{array}$ \\
\hline Mundlak variables & Yes & Yes & Yes & Yes \\
\hline Year & Yes & Yes & Yes & Yes \\
\hline Constant & $\begin{array}{c}7.344^{* * *} \\
(0.283)\end{array}$ & $\begin{array}{c}8.276^{* * *} \\
(0.271)\end{array}$ & $\begin{array}{c}8.899^{* * *} \\
(0.224)\end{array}$ & $\begin{array}{c}9.429^{* * *} \\
(0.280)\end{array}$ \\
\hline Observations & 4520 & 4520 & 4520 & 4520 \\
\hline
\end{tabular}

Note: Dependent variable is real consumption expenditure per adult equivalent. The variable is log transformed and valued in Ugandan Shillings. Bootstrapped standard errors in parentheses with 500 replications; ${ }^{*} p<0.10,{ }^{* *} p<0.05,{ }^{* * *} p<0.01$; All regressions include control variables, time averages of time varying variables, and year dummy. 
Table B.10: Welfare effects of crop diversity (Berger-Parker): Quantile regression estimates

\begin{tabular}{|c|c|c|c|c|}
\hline & $Q=20 \%$ & $\mathrm{Q}=40 \%$ & $\mathrm{Q}=60 \%$ & $\mathrm{Q}=80 \%$ \\
\hline Berger-Parker & $\begin{array}{c}0.051 \\
(0.064)\end{array}$ & $\begin{array}{c}0.040 \\
(0.049)\end{array}$ & $\begin{array}{c}0.042 \\
(0.049)\end{array}$ & $\begin{array}{c}0.041 \\
(0.056)\end{array}$ \\
\hline Generalized residual & $\begin{array}{l}-0.030 \\
(0.068)\end{array}$ & $\begin{array}{l}-0.037 \\
(0.053)\end{array}$ & $\begin{array}{l}-0.038 \\
(0.050)\end{array}$ & $\begin{array}{l}-0.040 \\
(0.058)\end{array}$ \\
\hline Age of head & $\begin{array}{c}0.006 \\
(0.006)\end{array}$ & $\begin{array}{c}0.005 \\
(0.003)\end{array}$ & $\begin{array}{l}0.007^{* *} \\
(0.003)\end{array}$ & $\begin{array}{c}0.011^{* * *} \\
(0.004)\end{array}$ \\
\hline Male headed & $\begin{array}{l}-0.072 \\
(0.134)\end{array}$ & $\begin{array}{l}-0.027 \\
(0.101)\end{array}$ & $\begin{array}{l}-0.069 \\
(0.097)\end{array}$ & $\begin{array}{l}-0.042 \\
(0.108)\end{array}$ \\
\hline Household size & $\begin{array}{c}-0.128^{* * *} \\
(0.019)\end{array}$ & $\begin{array}{c}-0.148^{* * *} \\
(0.014)\end{array}$ & $\begin{array}{c}-0.152^{* * *} \\
(0.014)\end{array}$ & $\begin{array}{c}-0.162^{* * *} \\
(0.019)\end{array}$ \\
\hline Head education & $\begin{array}{c}0.004 \\
(0.057)\end{array}$ & $\begin{array}{c}0.024 \\
(0.053)\end{array}$ & $\begin{array}{c}0.044 \\
(0.048)\end{array}$ & $\begin{array}{c}0.022 \\
(0.050)\end{array}$ \\
\hline Asset value (log) & $\begin{array}{l}0.102^{* * *} \\
(0.019)\end{array}$ & $\begin{array}{c}0.094^{* * *} \\
(0.012)\end{array}$ & $\begin{array}{l}0.091^{* * *} \\
(0.015)\end{array}$ & $\begin{array}{c}0.079^{* * *} \\
(0.018)\end{array}$ \\
\hline Land size (log) & $\begin{array}{c}0.028 \\
(0.018)\end{array}$ & $\begin{array}{c}0.049^{* * *} \\
(0.018)\end{array}$ & $\begin{array}{l}0.059^{* * *} \\
(0.017)\end{array}$ & $\begin{array}{l}0.046^{* *} \\
(0.021)\end{array}$ \\
\hline Livestock holding & $\begin{array}{c}0.005 \\
(0.009)\end{array}$ & $\begin{array}{l}-0.000 \\
(0.007)\end{array}$ & $\begin{array}{c}0.006 \\
(0.006)\end{array}$ & $\begin{array}{c}0.007 \\
(0.008)\end{array}$ \\
\hline Remittances & $\begin{array}{c}0.048 \\
(0.045)\end{array}$ & $\begin{array}{c}0.032 \\
(0.037)\end{array}$ & $\begin{array}{l}-0.016 \\
(0.033)\end{array}$ & $\begin{array}{l}-0.053 \\
(0.043)\end{array}$ \\
\hline Distance to road & $\begin{array}{l}-0.009 \\
(0.015)\end{array}$ & $\begin{array}{l}-0.007 \\
(0.013)\end{array}$ & $\begin{array}{l}-0.016 \\
(0.011)\end{array}$ & $\begin{array}{l}-0.001 \\
(0.020)\end{array}$ \\
\hline Distance to market & $\begin{array}{l}-0.013 \\
(0.009)\end{array}$ & $\begin{array}{l}-0.004 \\
(0.006)\end{array}$ & $\begin{array}{c}0.004 \\
(0.005)\end{array}$ & $\begin{array}{c}0.013 \\
(0.012)\end{array}$ \\
\hline Mundlak variables & Yes & Yes & Yes & Yes \\
\hline Year & Yes & Yes & Yes & Yes \\
\hline Constant & $\begin{array}{l}7 \cdot 319^{* * *} \\
(0.277)\end{array}$ & $\begin{array}{c}8.190^{* * *} \\
(0.213)\end{array}$ & $\begin{array}{c}8.694^{* * *} \\
(0.214)\end{array}$ & $\begin{array}{c}9.376^{* * *} \\
(0.256)\end{array}$ \\
\hline Observations & 4518 & 4518 & 4518 & 4518 \\
\hline
\end{tabular}

Note: Dependent variable is real consumption expenditure per adult equivalent. The variable is log transformed and valued in Ugandan Shillings. Bootstrapped standard errors in parentheses with 500 replications; ${ }^{*} p<0.10,{ }^{* *} p<0.05,{ }^{* * *} p<0.01$; All regressions include control variables, time averages of time varying variables, and year dummy. 
Table B.11: Effects of crop diversity on informal insurance: FE-IV estimates

\begin{tabular}{|c|c|c|c|c|}
\hline & Count Index & Shannon-Weaver & Composite Entropy & Berger-Parker \\
\hline \multirow[t]{2}{*}{ Crop diversity } & -0.008 & $-0.151^{*}$ & $-0.719^{* *}$ & $-0.093^{* *}$ \\
\hline & (0.016) & $(0.082)$ & $(0.300)$ & $(0.042)$ \\
\hline \multirow[t]{2}{*}{ Age of head } & -0.002 & -0.001 & -0.001 & -0.001 \\
\hline & (0.003) & (0.003) & (o.003) & (o.003) \\
\hline \multirow[t]{2}{*}{ Male headed } & 0.001 & 0.003 & 0.009 & 0.009 \\
\hline & $(0.052)$ & $(0.051)$ & $(0.051)$ & $(0.051)$ \\
\hline \multirow[t]{2}{*}{ Household size } & -0.000 & 0.001 & 0.001 & 0.001 \\
\hline & (o.oo8) & (o.oo8) & (o.oo8) & (o.oo8) \\
\hline \multirow[t]{2}{*}{ Head education } & 0.025 & 0.031 & 0.035 & 0.031 \\
\hline & $(0.023)$ & (0.023) & (o.023) & (o.023) \\
\hline \multirow[t]{2}{*}{ Asset value (log) } & -0.007 & -0.006 & -0.006 & -0.008 \\
\hline & (o.0o6) & (o.oo6) & (o.oo6) & $(0.005)$ \\
\hline \multirow[t]{2}{*}{ Land size } & $-0.000^{* *}$ & $-0.000^{* *}$ & $-0.000^{* *}$ & $-0.000^{* *}$ \\
\hline & (o.0oo) & (o.0oo) & (o.ooo) & (o.ooo) \\
\hline \multirow[t]{2}{*}{ Livestock holding } & -0.001 & 0.000 & 0.001 & 0.000 \\
\hline & (0.004) & (0.004) & $(0.004)$ & $(0.004)$ \\
\hline \multirow[t]{2}{*}{ Remittances } & $0.059^{* * *}$ & $0.059^{* * *}$ & $0.060^{* * *}$ & $0.058^{* * *}$ \\
\hline & (0.019) & (0.019) & (o.019) & (o.019) \\
\hline \multirow[t]{2}{*}{ Distance to road } & -0.013 & -0.012 & -0.013 & -0.011 \\
\hline & (0.010) & (0.010) & (0.010) & (0.010) \\
\hline \multirow[t]{2}{*}{ Distance to market } & 0.012 & $0.014^{*}$ & $0.015^{* *}$ & 0.012 \\
\hline & (o.009) & (o.oo8) & (o.007) & (o.0o8) \\
\hline \multirow[t]{2}{*}{ Production shock } & $0.169^{* * *}$ & $0.168^{* * *}$ & $0.167^{* * *}$ & $0.169^{* * *}$ \\
\hline & $(0.015)$ & $(0.015)$ & $(0.015)$ & $(0.015)$ \\
\hline \multirow[t]{2}{*}{ Health shock } & $0.428^{* * *}$ & $0.429^{* * *}$ & $0.431^{* * *}$ & $0.436^{* * *}$ \\
\hline & $(0.027)$ & $(0.027)$ & $(0.027)$ & $(0.027)$ \\
\hline \multirow[t]{2}{*}{ High cost of inputs } & -0.087 & -0.079 & -0.073 & -0.074 \\
\hline & $(0.064)$ & $(0.064)$ & (o.o66) & (o.o66) \\
\hline Year & Yes & Yes & Yes & Yes \\
\hline \multirow[t]{2}{*}{ Constant } & -0.119 & -0.045 & 0.143 & 0.035 \\
\hline & $(0.261)$ & $(0.251)$ & $(0.249)$ & $(0.257)$ \\
\hline F test of excluded instruments & $32.95^{* * *}$ & $24 \cdot 47^{* * *}$ & $11.21^{* * *}$ & $11.42^{* * *}$ \\
\hline Kleibergen-Paap Wald F statistic & $32.95^{* *}$ & $24 \cdot 47^{* *}$ & $11.21^{*}$ & $11.42^{*}$ \\
\hline Sargan-Hansen statistic & 3.26 & 3.95 & $4 \cdot 33$ & $4 \cdot 34$ \\
\hline Observations & 4520 & 4520 & 4520 & 4518 \\
\hline$\chi^{2}$ & $478.8^{* * *}$ & $486.2^{* * *}$ & $473 \cdot 6^{* * *}$ & $480.1^{* * *}$ \\
\hline
\end{tabular}

Note: Standard errors in parentheses; ${ }^{*} p<0.10,{ }^{* *} p<0.05,{ }^{* * *} p<0.01$ 
Table B.12: Effects of crop diversity on involuntary diet change: FE-IV estimates

\begin{tabular}{|c|c|c|c|c|}
\hline & Count Index & Shannon-Weaver & Composite Entropy & Berger-Parker \\
\hline \multirow[t]{2}{*}{ Crop diversity } & $-0.032^{*}$ & $-0.198^{*}$ & $-0.676^{*}$ & -0.083 \\
\hline & (o.019) & (0.101) & (o.371) & $(0.052)$ \\
\hline \multirow[t]{2}{*}{ Age of head } & -0.000 & 0.000 & 0.000 & 0.000 \\
\hline & (o.003) & (0.004) & (0.004) & (0.004) \\
\hline \multirow[t]{2}{*}{ Male headed } & -0.025 & -0.017 & -0.011 & -0.012 \\
\hline & $(0.062)$ & $(0.063)$ & $(0.064)$ & $(0.062)$ \\
\hline \multirow[t]{2}{*}{ Household size } & 0.008 & 0.008 & 0.009 & 0.008 \\
\hline & $(0.007)$ & (o.oo8) & (o.oo8) & (o.oo8) \\
\hline \multirow[t]{2}{*}{ Head education } & 0.007 & 0.011 & 0.012 & 0.008 \\
\hline & $(0.028)$ & $(0.028)$ & (o.029) & $(0.028)$ \\
\hline \multirow[t]{2}{*}{ Asset value (log) } & -0.007 & -0.007 & -0.007 & -0.009 \\
\hline & (o.006) & (o.006) & (o.006) & (0.006) \\
\hline \multirow[t]{2}{*}{ Land size } & $-0.000^{*}$ & $-0.000^{*}$ & $-0.000^{*}$ & $-0.001^{* *}$ \\
\hline & (o.ooo) & (o.ooo) & (o.ooo) & (o.ooo) \\
\hline \multirow[t]{2}{*}{ Livestock holding } & -0.005 & -0.004 & -0.003 & -0.004 \\
\hline & (o.004) & (0.004) & (0.004) & (0.004) \\
\hline \multirow[t]{2}{*}{ Remittances } & 0.004 & 0.005 & 0.006 & 0.004 \\
\hline & $(0.020)$ & $(0.020)$ & (0.021) & $(0.020)$ \\
\hline \multirow[t]{2}{*}{ Distance to road } & 0.005 & 0.006 & 0.005 & 0.007 \\
\hline & (o.009) & (0.009) & (o.oo8) & (o.009) \\
\hline \multirow[t]{2}{*}{ Distance to market } & -0.005 & -0.004 & -0.003 & -0.006 \\
\hline & $(0.006)$ & $(0.006)$ & (o.006) & (o.oo6) \\
\hline \multirow[t]{2}{*}{ Production shock } & $0.463^{* * *}$ & $0.460^{* * *}$ & $0.459^{* * *}$ & $0.460^{* * *}$ \\
\hline & $(0.017)$ & $(0.017)$ & $(0.017)$ & $(0.017)$ \\
\hline \multirow[t]{2}{*}{ Health shock } & $0.070^{* * *}$ & $0.072^{* * *}$ & $0.074^{* * *}$ & $0.080^{* * *}$ \\
\hline & $(0.026)$ & $(0.026)$ & $(0.027)$ & $(0.027)$ \\
\hline \multirow[t]{2}{*}{ High cost of inputs } & 0.018 & 0.029 & 0.032 & 0.031 \\
\hline & $(0.070)$ & $(0.070)$ & (o.069) & (0.068) \\
\hline Year & Yes & Yes & Yes & Yes \\
\hline \multirow[t]{2}{*}{ Constant } & $0.485^{* *}$ & $0.527^{* *}$ & $0.670^{* *}$ & $0.561^{* *}$ \\
\hline & $(0.243)$ & $(0.247)$ & $(0.276)$ & $(0.253)$ \\
\hline F test of excluded instruments & $32.95^{* * *}$ & $24 \cdot 47^{* * *}$ & $11.21^{* * *}$ & $11.42^{* * *}$ \\
\hline Kleibergen-Paap Wald F statistic & $32.95^{* *}$ & $24.47^{* *}$ & $11.21^{*}$ & $11.42^{*}$ \\
\hline Sargan-Hansen (Hansen J) statistic & 6.80 & 6.47 & 5.78 & 5.64 \\
\hline Observations & 4520 & 4520 & 4520 & 4518 \\
\hline$\chi^{2}$ & $1176.0^{* * *}$ & $1147 \cdot 4^{* * *}$ & $1118.2^{* * *}$ & $1115 \cdot 4^{* * *}$ \\
\hline
\end{tabular}

Note: Standard errors in parentheses; ${ }^{*} p<0.10,{ }^{* *} p<0.05,{ }^{* * *} p<0.01$ 
Table B.13: Crop diversity and welfare: Estimates from balanced panel

\begin{tabular}{|c|c|c|c|c|}
\hline & Count index & Shannon-Weaver & Composite Entropy & Berger-Parker \\
\hline \multicolumn{5}{|c|}{ A: Household dietary diversity } \\
\hline \multirow[t]{2}{*}{ (1) FE-IV } & 0.112 & $0.992^{* *}$ & $3 \cdot 562^{*}$ & 0.402 \\
\hline & $(0.086)$ & $(0.501)$ & $(2.024)$ & $(0.248)$ \\
\hline \multirow[t]{2}{*}{ (2) 2 SRI } & 0.120 & $1.366^{* * *}$ & $5.163^{* * *}$ & $0.294^{*}$ \\
\hline & $(0.081)$ & $(0.435)$ & $(1.498)$ & $(0.150)$ \\
\hline \multirow[t]{2}{*}{ (3) FE-Poisson } & $0.007^{* *}$ & $0.039^{* * *}$ & $0.097^{* * *}$ & 0.008 \\
\hline & $(0.003)$ & $(0.014)$ & $(0.036)$ & (0.005) \\
\hline \multirow[t]{2}{*}{ (4) Pooled OLS } & $0.133^{* * *}$ & $0.498^{* * *}$ & $0.896^{* * *}$ & $0.102^{* * *}$ \\
\hline & $(0.020)$ & (0.102) & $(0.288)$ & $(0.037)$ \\
\hline \multicolumn{5}{|c|}{ B: Consumption expenditure } \\
\hline \multirow[t]{2}{*}{ (1) FE-IV } & $0.042^{*}$ & $0.229^{*}$ & 0.623 & $0.120^{*}$ \\
\hline & $(0.022)$ & $(0.129)$ & $(0.497)$ & $(0.067)$ \\
\hline \multirow[t]{2}{*}{ (2) 2 SRI } & $0.072^{* * *}$ & $0.491^{* * *}$ & $1.654^{* * *}$ & $0.076^{*}$ \\
\hline & (0.021) & (o.117) & (0.405) & (0.041) \\
\hline \multirow[t]{2}{*}{ (3) $\mathrm{CRE}$} & $0.013^{* *}$ & 0.032 & 0.019 & 0.014 \\
\hline & (0.006) & $(0.026)$ & $(0.071)$ & (0.010) \\
\hline \multirow[t]{2}{*}{ (4) Pooled OLS } & $0.021^{* * *}$ & 0.020 & -0.108 & -0.005 \\
\hline & (0.006) & (0.029) & $(0.082)$ & (0.010) \\
\hline
\end{tabular}

Note: Number of observations is 3126 . In panels A and B, (1) reports fixed effects-IV regression results; (2) reports results from the 2SRI method; for Panel A, (3) reports coefficients of fixed effects poison and in Panel B, (3) reports CRE estimates; (4) reports pooled OLS estimates in both panels; All regressions include control variables and time dummies; Time averages of all explanatory variables are included in (2). Standard errors in parentheses are clustered at the household; * $p<0.10,{ }^{* *} p<0.05,{ }^{* * *} p<0.01$. 
Table B.14: Crop diversity and risk coping: Estimates from balanced panel

Count index Shannon-Weaver Composite Entropy Berger-Parker

\section{A: Informal insurance}

$\begin{array}{lcccc}\text { (1) } 2 \text { SRI } & -0.034^{* *} & -0.231^{* * *} & -0.880^{* * *} & -0.132^{* * *} \\ & (0.015) & (0.079) & (0.285) & (0.038) \\ \text { (2) FE-IV } & -0.007 & -0.151 & -0.795^{* *} & -0.082 \\ & (0.018) & (0.098) & (0.379) & (0.051) \\ \text { (3) CRE probit } & -0.003 & -0.044^{* *} & -0.127^{* *} & -0.022^{* * *} \\ & (0.004) & (0.020) & (0.053) & (0.008) \\ \text { (4) FE logit } & -0.071 & -0.671^{* *} & -1.919^{* * *} & -0.295^{* * *} \\ & (0.053) & (0.261) & (0.729) & (0.097)\end{array}$

B: Change in diets

\begin{tabular}{lcccc} 
(1) 2 SRI & $-0.038^{* * *}$ & $-0.222^{* * *}$ & $-0.836^{* * *}$ & -0.098 \\
& $(0.013)$ & $(0.079)$ & $(0.308)$ & $(0.038)$ \\
(2) FE-IV & $-0.044^{* *}$ & $-0.237^{*}$ & -0.713 & -0.105 \\
& $(0.022)$ & $(0.124)$ & $(0.474)$ & $(0.067)$ \\
(3) CRE probit & $-0.010^{* *}$ & -0.010 & 0.029 & 0.008 \\
& $(0.005)$ & $(0.022)$ & $(0.059)$ & $(0.008)$ \\
(4) FE logit & -0.066 & -0.087 & 0.118 & 0.075 \\
& $(0.046)$ & $(0.222)$ & $(0.596)$ & $(0.082)$ \\
\hline \hline
\end{tabular}

Note: (1) reports average partial effects (APEs) from the 2SRI or control function method; (2) reports fixed effects-IV regression results for both risk coping outcome equations where we allow endogeneity of crop diversification; (3) reports APEs from CRE probit (pooled maximum likelihood estimations), and (4) reports fixed effects logit coefficients; all regressions include control variables; (2) and (3) include time averages of all explanatory variables, year and region dummies. Standard errors in parentheses are clustered at the household level; ${ }^{*} p<0.10,{ }^{* *} p<0.05,{ }^{* * *} p<0.01$. 



\section{FOOD STORAGE INNOVATIONS, FOOD SECURITY AND WELFARE IN ETHIOPIA*}

\section{I INTRODUCTION}

Postharvest loss presents a significant challenge for food security and agricultural production efficiencies in developing countries. In developed economies, it is characterized as a consumer behavior while it is largely caused by financial, managerial and technical deficiencies in developing countries (Premanandh, 2011; FAO, 2011; Conteh et al., 2015). Consequently, in developing countries, food loss is concentrated at stages 'close to the farm' such as production, handling, and storage (Parfitt et al., 2010; Premanandh, 2011; Lipinski et al., 2013). The problem is more acute in Sub-Saharan Africa (SSA) where a significant portion of the production is lost because of poor storage, lack of structured markets, limited processing capacity and weather related factors (Shiferaw et al., 2011; Tefera et al., 2011; Tefera, 2012; Affognon et al., 2015). While global estimates show that roughly one-third of the food produced for human consumption is lost or wasted (FAO, 2011), postharvest loss in SSA is estimated to be about $37 \%$ which is equivalent to an annual per capita food loss between 120 and 170 kgs (FAO, 2011; Sheahan and Barrett, 2017). ${ }^{1}$ In Eastern and Southern Africa alone, food losses are valued at $\$ 1.6$ billion per year which is nearly $13.5 \%$ of the total value of grain production (World Bank et al., 2011; Abass et al., 2014). This evidence suggests that postharvest loss could be a threat to the food and nutrition security and welfare of rural households.

Postharvest loss reduces the food available for consumption and, therefore, directly affects food security, nutrition, and household consumption. Food loss tightens food markets and increases food prices particularly during the lean season by cutting part of the food supply in the markets (Tefera et al., 2011). This in turn lowers farmers' income (Hodges and Stathers, 2013). For the rural poor who are often net-buyers of

* The content of this chapter is published as: Tesfaye, W. Tirivayi, N. (2018). The impacts of postharvest storage innovations on food security and welfare in Ethiopia. Food Policy, 75(100), 52-67. An earlier version of the chapter has been published as UNU-MERIT working paper \#2016-063.

1 The postharvest loss estimates in SSA vary widely by region and crop type (Lipinski et al., 2013; Rutten, 2013; Rosegrant et al., 2015; Affognon et al., 2015). The value of post-harvest cereal grain losses alone in SSA could total $\$ 4$ billion a year that could feed about 48 million people at 2,500 kcal per person per day (World Bank et al., 2011; Stathers et al., 2013). 
food, an increase in food prices would significantly lower the purchasing power of their (disposable) income. Postharvest crop loss leads to grain quality deterioration that forces farmers to end up supplying their produce to lower value and informal markets (Hodges and Stathers, 2013). In the absence of well-functioning insurance and credit markets, the risk of crop storage loss coupled with financial pressure or liquidity constraints might compel farm households to sell most of their produce immediately after harvest to finance household outlays (Tefera et al., 2011). As a result, they might lose the opportunity to benefit from inter-seasonal price variations. Moreover, they will be forced to buy food during the lean season when prices are at their peak. This would, ultimately, exert a negative effect on their welfare and access to food (H.Gabriel and Hundie, 2006).

Besides its negative economic impacts, postharvest loss has substantial environmental repercussions manifested through the unsustainable use of scarce natural resources (e.g., land, water), production inputs (fertilizer, pesticides) and energy (Lipinski et al., 2013; Kummu et al., 2012; World Bank et al., 2011). Producing extra food to compensate for losses also represents a waste of resources (Lipinski et al., 2013; Stathers et al., 2013). This would not only result in long-term food insecurity and diminished welfare but also jeopardizes future generations' food production capacity. In sum, postharvest loss entails opportunity costs and resource misallocation. Therefore, tackling the causes of postharvest loss along the entire food chain would significantly help in improving food security and welfare, and in reducing the environmental footprints of food systems (Hodges et al., 2011; Kummu et al., 2012; Parfitt et al., 2010; Sheahan and Barrett, 2017).

Improved storage technologies are useful strategies for preventing post-harvest losses (World Bank et al., 2011) and improving household welfare (Fuglie and Bosch, 1995; Parmar et al., 2017). ${ }^{2}$ Improved crop storage technologies include metal silos, air tight drums, modern store or improved locally made structures (Kaminski and Christiaensen, 2014; Lipinski et al., 2013; Rosegrant et al., 2015). These technologies could also help households cope with increasing food demand, to improve the efficiency of the agricultural sector, and enhance agricultural productivity and sustainability (Basu and Wong, 2015; Lybbert and Sumner, 2012; Lipinski et al., 2013). However, for many years, significant resources have been devoted towards increasing agricultural production in developing countries, without an equal push for reducing postharvest losses (World Bank et al., 2011; Affognon et al., 2015). Accordingly, there has been bias towards production and pre-harvest research and policies. Due to the renewed interest in agriculture in the aftermath of the recent food, climate and financial crises (Dethier and Effenberger, 2012), postharvest loss mitigation interventions are now seen as important elements of reducing food insecurity in SSA (Hodges and Stathers, 2013; Sheahan and Barrett, 2017; World Bank et al., 2011). As a result, a number of

2 See Stathers et al. (2013) for discussion of the possible channels through which postharvest management (e.g. food storage) affects food security and wellbeing. 
improved storage technologies have been introduced to farmers in SSA (Hodges et al., 2011; Tefera et al., 2011). However, few studies assess farm households' decisions to use such technologies and their impact on household welfare. The literature on the welfare impacts of agricultural innovations is highly skewed to pre-harvest or production technologies and the evidence base on the impacts of postharvest technologies is thin.

Recent reviews of the literature on postharvest loss mitigation interventions and their impact underscore the lack of rigorous studies that establish an empirical link between these interventions (e.g. postharvest storage innovations) and household welfare (Affognon et al., 2015; Sheahan and Barrett, 2017). Among the few exceptions is a study by Gitonga et al. (2013). The authors use propensity score matching and find that metal silos almost completely reduce postharvest storage losses, help farmers increase months of maize storage, reduce expenditure on storage chemicals, enable sale of surplus at higher prices and reduce the period of inadequate food provision in Kenya. However, their evaluation approach did not control for possible bias from unobserved endogeneity. Cunguara and Darnhofer (2011) use a doubly robust estimator, sub-classification regression and matching methods, and find that improved granaries had no significant impact on household income in rural Mozambique. Mutenje et al. (2016), using a multinomial endogenous switching regression model, find that the joint adoption of improved storage and improved maize varieties provides the highest maize yield in Malawi compared to other combinations of technologies. Using double hurdle and Tobit models, Bokusheva et al. (2012) find that the use of metal silos improves the food security and well-being of user households in four Central American Countries (El Salvador, Guatemala, Honduras, and Nicaragua). They also emphasize that a significant proportion of the metal silos are subsidized in most of the Central American countries and in some cases, the metal silos are donated to poor farmers.

This study focuses on Ethiopia, a Sub-Saharan African country where climate change, postharvest loss, food insecurity, and undernutrition are ubiquitous. Food security and child undernutrition remain critical issues in the country particularly in rural areas. The major sources of food in Ethiopia are food grains (cereals, pulses, and oil crops) followed by starchy roots and tubers such as potato, sweet potato and Ethiopian banana (enset) (Chauvin et al., 2012; H.Gabriel and Hundie, 2006). At the farm level, crop storage is mainly undertaken using traditional and poor quality practices such as bags or sacks and traditional granaries (H.Gabriel and Hundie, 2006; Mengistu and Garrard., 2014). While recent information on food crop storage technologies and postharvest loss in Ethiopia is largely nonexistent, some estimates show that postharvest loss ranges from $5 \%$ to $26 \%$ mainly due to poor storage and weakness in the postharvest system (H.Gabriel and Hundie, 2006). Since many households in Ethiopia suffer protracted periods of food shortage, such a loss is tremendous. Improved storage methods have been promoted in Ethiopia for at least two decades by different 
organizations (e.g. the Sasakawa Global 2000 and Ethiopian Ministry of Agriculture and Rural Development) through participatory action research and field demonstrations (Mengistu and Garrard., 2014). However, we are not aware of any study that rigorously demonstrates the impact of improved storage techniques on food and nutrition security and welfare. This study, therefore, aims to assess the food security and household welfare impacts of postharvest food storage technologies. We employ a diverse set of identification and estimation strategies that address selection bias and endogeneity.

The chapter contributes to the bodies of literature on the impacts of agricultural innovations, postharvest research and storage economics in the following ways. First, unlike previous studies that used a single measure for food security, we use various objective and subjective measures to capture the different dimensions of food security. Second, in addition to contributing to the literature that links improved agricultural innovations and household welfare, we extend the link to intrahousehold nutrition security by estimating the impact on child growth. Until recently, there has been no empirical evidence showing how improved crop storage techniques improve child nutrition (Chaboud and Daviron, 2017). The study employed endogenous switching regression treatment effects frameworks that are increasingly being used to evaluate impact in a cross-sectional setting due to their merit in controlling for unobserved endogeneity. We apply the endogenous switching regression models for both linear and nonlinear outcomes.

The rest of the chapter is organized as follows. The next section describes the conceptual framework, empirical estimation strategies. Section 4.3 discusses the data, variables and provides descriptive statistics. Section 4.4 discusses the empirical results. The concluding section highlights the key findings and policy implications of the study.

\subsection{METHODOLOGY}

\subsubsection{Conceptual framework}

Farm households are heterogeneous agents and their decision to use improved storage technology is constrained by resources, information and the availability of the technology (Foster and Rosenzweig, 2010). Investments on improved storage technologies will only be attractive to a household if the perceived benefits substantially offset the costs as technical superiority alone is insufficient. Hence, a household's decision to use the innovation could be viewed through the lens of constrained optimization where the household chooses the technology if its use is expected to be beneficial (de Janvry et al., 2010). 
Let $S_{i}$ denote a binary indicator of improved storage technology use. Let $U_{1}$ denote the benefit from the use of improved storage technologies and $U_{0}$ denote the benefits to the household of not using improved storage. Under a random utility framework, a rational farm household will choose to use improved storage innovations if the net benefit from use is positive i.e. $U_{1}>U_{0}$. Since the net benefit or utility from use $\left(U^{*}=U_{1}-U_{0}\right)$ is not observable, it can be represented by a latent variable which is itself a function of observed characteristics $\left(Z_{i}\right)$ and error term $\left(u_{i}\right)$. Hence, the expected benefit to the $i^{t h}$ household derived from the use of the technology can be determined by a set of observable variables $\left(Z_{i}\right)$, variables that are not observable $\left(\eta_{i}\right)$, and an independently and identically distributed (i.i.d.) error term $\left(u_{i}\right)$.

Let $E\left(U^{*}\right)$ denote the expected utility from the use of an improved storage technology. A household decides to use an improved storage technology if the net expected benefit or utility from use is positive i.e. if $E\left(U^{*}\right)>0$ which means when $E\left(U_{1}-U_{0}\right)>0$ or $E\left(U_{1}\right)>E\left(U_{0}\right)$. However, the utility function is non-observable. What we can observe are the actual outcomes: food security and welfare. Food security or welfare outcomes, $Y_{i}$, are also a function of improved storage technology use $\left(S_{i}\right)$, observed variables such as household characteristics, system level factors, climatic factors and agroecology $\left(X_{i}\right)$, unobserved variables such as innate abilities and managerial capacity $\left(V_{i}\right)$, and an iid error term $\left(\epsilon_{i}\right)$. The above relationships are represented as follows.

$$
\begin{gathered}
S_{i}=S_{i}\left(Z_{i}, \eta_{i}, u_{i}\right) \\
Y_{i}=Y_{i}\left[X_{i}, S_{i}\left(Z_{i}, \eta_{i}, u_{i}\right), V_{i}, \epsilon_{i}\right]
\end{gathered}
$$

The observed variables in the adoption (selection) and outcome equations ( $X$ and $Z$ ), and the unobserved variables ( $\eta$ and $V$ ) can share elements. Hence, there is a need to investigate the interdependence between the improved storage technology adoption equation and outcome equations.

\subsubsection{Estimation strategy}

The interest here is to estimate the impact that use of improved storage technologies has on food security and welfare for user households. When households are not randomly assigned to improved storage technology users or non-users, they either self-select into use or the technologies might be provided to targeted households (Alene and Manyong, 2007). Hence, the decision to use improved storage innovations is considered potentially endogenous. Failure to account for selection bias and endogeneity would obscure the true impact of the technology. Recent developments in 
the econometrics literature make an estimation of causal effects possible using nonexperimental techniques in the absence of randomization.

We address the selection and endogeneity problems by utilizing endogenous switching regression (ESR) models. which account for endogeneity by estimating a simultaneous equations model with endogenous switching using the full information maximum likelihood method (Lokshin and Sajaia, 2004, 2011). Although it relies on normality assumptions like the instrumental variable methods, the approach is more efficient than instrumental variables techniques. By modeling both selection and outcome equations, ESR has the advantage of controlling for factors which affect the treatment itself and disentangling the factors influencing the outcomes among improved storage technology users and non-users (Besley and Case, 2000). In addition to accounting for selection bias arising from unobserved factors that potentially affect both improved storage technology use and the outcomes, ESR models control for structural differences between improved storage users and non-users regarding the outcome functions (Alene and Manyong, 2007). Previous empirical studies have employed the framework to study the impact of modern technologies on food security and welfare (Asfaw et al., 2012; Khonje et al., 2015; Shiferaw et al., 2014; Coromaldi et al., 2015) and the impact of climate change adaptation on food security (Di Falco et al., 2011).

\subsubsection{Endogenous switching regression}

Consider a farm household $i$ that faces a decision on whether or not to use improved storage technologies. Let $S_{i}$ take a value of 1 for households who decide to use an improved storage technology and o otherwise. This leads to two possible states: a decision to use $(S=1)$ and not to use $(S=0)$, and two population units: users and non-users.

Conditional on the household's decision to use an improved storage technology denoted by a selection function, $S_{i}$, there are two potential outcomes to the two population units: the outcome without treatment $\left(Y_{0}\right)$ and the outcome with treatment $\left(Y_{1}\right)$. This can be put in a 'potential outcome framework' as:

$$
\begin{gathered}
Y_{i}=\left(1-S_{i}\right) Y_{0 i}+S_{i} Y_{1 i} \\
Y_{i}= \begin{cases}Y_{1 i}, & \text { if } S_{i}=1 \\
Y_{0 i}, & \text { if } S_{i}=0\end{cases}
\end{gathered}
$$

The impact of treatment (treatment effects) is therefore $Y_{1}-Y_{0}$. However, the challenge here is that the two outcomes cannot be observed simultaneously for a user 
household (Heckman et al., 1998). Hence, taking a simple difference and averaging across a random sample of households cannot give the true effect of the treatment. Endogenous switching regression is the most attractive approach for properly estimating the treatment effect.

In the ESR model, the behavior of a farm household is described with two outcome equations and a selection function that determines which regime the household faces. A household's decision to use an improved storage technology is represented by the following latent variable framework (Lokshin and Sajaia, 2004, 2011).

$$
S_{i}^{*}=\tau Z_{i}+u_{i}
$$

With

$$
S_{i}=\left\{\begin{array}{l}
1 \text { if } S_{i}^{*}>0 \\
0 \text { if } S_{i}^{*} \leq 0
\end{array}\right.
$$

Conditional on selection, the outcomes are represented by a switching regime as follows:

$$
\begin{aligned}
& \text { Regime } 1: y_{i 1}=\beta_{1} X_{1 i}+\epsilon_{1 i} \text { if } S_{i}=1 \\
& \text { Regime } 2: y_{i 0}=\beta_{0} X_{0 i}+\epsilon_{0 i} \text { if } S_{i}=0
\end{aligned}
$$

$Z$ represents a vector of observable variables that will determine the decision to use improved storage technologies such as household (head's) characteristics, system level variables, and climatic factors. In the continuous equations, $y_{i j}$ are the outcome variables; $X_{1 i}$ and $X_{0 i}$ are vectors of explanatory variables assumed to be weakly exogenous; and $\beta_{1}, \beta_{0}$, and $\tau$ are vectors of parameters to be estimated. The error terms of the continuous outcome $\left(\epsilon_{1 i}\right.$ and $\left.\epsilon_{0 i}\right)$ and selection equations $\left(u_{i}\right)$ are assumed to follow a trivariate normal distribution with zero mean vector and covariance matrix defined as: ${ }^{3}$

$$
\Omega=\left(\begin{array}{ccc}
\sigma_{u}^{2} & \sigma_{1 u} & \sigma_{0 u} \\
\sigma_{1 u} & \sigma_{1}^{2} & \cdot \\
\sigma_{0 u} & \cdot & \sigma_{0}^{2}
\end{array}\right)
$$

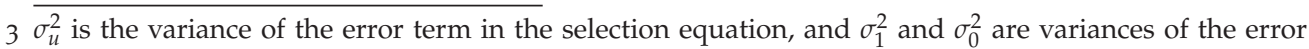
terms in the continuous equations. The covariances are given as non-diagonal values. The variance of the error term in the selection equation can be assumed to be 1 ( $\tau$ is estimable only up to a scalar factor). In the covariance matrix, the dot (.) indicates that the two outcomes cannot be observed simultaneously for a particular household (Lokshin and Sajaia, 2011). 
Since the error terms in the selection equation are correlated with those in the outcome equations, the means (expected values) of the error terms in the outcome equations conditional on the sample selection are non-zero (Di Falco et al., 2011). If the estimated covariances turn to be significant, then improved storage technology use and the outcomes are correlated and this provides evidence of endogenous switching. The ESR model is estimated using full information maximum likelihood (Clougherty and Duso, 2015; Lee and Trost, 1978; Lokshin and Sajaia, 2004).

After estimating the model's parameters, the conditional expectations or expected outcomes are computed as follows.

For improved storage technology users who actually used:

$$
E\left(y_{1 i} \mid S_{i}=1, x_{1 i}\right)=x_{1 i} \beta_{1}+\sigma_{1} \rho_{1} f\left(\tau Z_{i}\right) / F\left(\tau Z_{i}\right)
$$

For improved storage technology non-users had they decided to use (counterfactual):

$$
E\left(y_{1 i} \mid S_{i}=0, x_{1 i}\right)=x_{1 i} \beta_{1}-\sigma_{1} \rho_{1} f\left(\tau Z_{i}\right) /\left(1-F\left(\tau Z_{i}\right)\right)
$$

For improved storage technology users had they decided not to use (counterfactual):

$$
E\left(y_{0 i} \mid S_{i}=1, x_{0 i}\right)=x_{0 i} \beta_{1}+\sigma_{0} \rho_{0} f\left(\tau Z_{i}\right) / F\left(\tau Z_{i}\right)
$$

For improved storage technology non-users who actually did not use:

$$
E\left(y_{0 i} \mid S_{i}=0, x_{0 i}\right)=x_{0 i} \beta_{1}-\sigma_{0} \rho_{0} f\left(\tau Z_{i}\right) /\left(1-F\left(\tau Z_{i}\right)\right)
$$

Following Heckman et al. (2001) and Di Falco et al. (2011), the treatment effect on the treated (TT) is computed as the difference between the expected outcomes for farm households that used improved storage (equation 4.10) and the counterfactual hypothetical cases that they did not use (equation 4.12). The treatment effect on the untreated (TU) is computed as the difference between the outcomes they would have obtained in the counterfactual scenario that they decided to use (equation 4.13) and the expected outcomes for farm households who did not use improved storage (equation 4.11). The conditional expectation equations are also used to calculate heterogeneous effects (Di Falco et al., 2011; Carter and Milon, 2005). Households that use improved storage innovations may have better food security or welfare than the households that did not use regardless of the fact that they decided to use, but because of unobserved characteristics such as skills and knowledge i.e. the effect of base heterogeneity (Carter and Milon, 2005). The computation of the effect of base heterogeneity for households that decided to use $\left(\mathrm{BH}_{1}\right)$ and for the households who did not 
Table 4.1: Conditional expectations, treatment effects, and heterogeneous effects

\begin{tabular}{|c|c|c|c|}
\hline \multirow[t]{2}{*}{ Sub-samples } & \multicolumn{2}{|c|}{ Decision stage } & \multirow[t]{2}{*}{ Treatment effects } \\
\hline & To use & Not to use & \\
\hline User households & (a) $E\left(y_{1 i} \mid S_{i}=1\right)$ & (b) $E\left(y_{0 i} \mid S_{i}=1\right)$ & TT \\
\hline Non-user households & (c) $E\left(y_{1 i} \mid S_{i}=0\right)$ & (d) $E\left(y_{0 i} \mid S_{i}=0\right)$ & TU \\
\hline Heterogeneous effects & $B H_{1}$ & $B H_{0}$ & $T H$ \\
\hline
\end{tabular}

Note: TT: the effect of the treatment (use of improved storage) on the treated (user households)

TU: the effect of the treatment on the untreated (non-user households)

$B H_{i}=$ the effect of base heterogeneity for households that used $(\mathrm{S}=1)$ and did not use $(\mathrm{S}=\mathrm{0})$

$\mathrm{TH}=\mathrm{TT}-\mathrm{TU}$ is the transitional heterogeneity

use improved storage technologies $\left(\mathrm{BH}_{0}\right)$ is indicated in Table 4.1. Another important statistic is transitional heterogeneity $(\mathrm{TH})$ which measures whether the effect of the improved storage technologies use is larger or smaller for households that used or for households that did not, in the counterfactual case that they did use (Di Falco et al., 2011).

\subsubsection{Endogenous switching probit model}

We are also interested in estimating the impact of improved storage innovations on various binary outcome measures of food security. Unlike for continuous outcome variables, accounting for sample selection and endogenous switching for binary outcomes where the data is fit using non-linear models is challenging (Heckman, 1986; Miranda and Rabe-Hesketh, 2006). Estimations using two-stage procedures (such as Heckman's sample selection model) would lead to wrong conclusions and produce inconsistent results. Hence, we utilize the endogenous switching probit framework which is analogous to the endogenous switching regression used for the continuous outcomes (Lokshin and Glinskaya, 2009; Lokshin and Sajaia, 2011; Miranda and RabeHesketh, 2006). The endogenous switching probit framework simultaneously models the use of an improved storage technology and the binary outcome equations in two stages. The first stage estimates the farm households' decision to use improved storage technologies using a probit model. In the second stage, the relationship between the binary outcomes and improved storage use along with a set of explanatory variables is determined using a probit model with selectivity correction.

Following Lokshin and Sajaia (2011), the binary outcomes conditional on improved storage use are specified as an endogenous switching regime model:

$$
\text { Regime } 1: y_{1 i}^{*}=\beta_{1} X_{1 i}+\epsilon_{1 i}, y_{1 i}=I\left(y_{1 i}^{*}>0\right)
$$




$$
\text { Regime } 2: y_{0 i}^{*}=\beta_{0} X_{0 i}+\epsilon_{0 i}, y_{0 i}=I\left(y_{0 i}^{*}>0\right)
$$

observed is a dichotomous realization of the latent variables and it is defined as:

$$
y_{i}=\left\{\begin{array}{l}
y_{1 i} \text { if } S_{i}=1 \\
y_{0 i} \text { if } S_{i}=0
\end{array}\right.
$$

where $y_{1 i}^{*}$ and $y_{0 i}^{*}$ are the latent variables that determine the observed binary outcomes $y_{1}$ and $y_{0}$ for improved storage users and non-users, respectively. $X_{1}$ and $X_{0}$ are vectors of weakly exogenous variables; $\beta_{1}$ and $\beta_{0}$ are vectors of parameters to be estimated, and $\epsilon_{1 i}$ and $\epsilon_{0 i}$ are the error terms in the outcome equations. ${ }^{4}$ We used a full information maximum likelihood (FIML) endogenous switching probit model to estimate the parameters of interest (see Lokshin and Glinskaya (2009); Lokshin and Sajaia (2011).

The effects of improved storage technology use on binary outcomes are estimated based on the methodological framework developed by Aakvik et al. (2000) and Lokshin and Sajaia (2011). Like the ESR model for continuous outcome variables, the switching probit model also allows for the estimation of the treatment effects on the treated (TT) and the treatment effects on the untreated (TU). The model also estimates the impact of using an improved storage technology for a household randomly selected from the population of households with characteristics $x$ (treatment effect, TE). The treatment effect can vary not only by the observed household characteristics $(x)$ but also by unobserved characteristics $(\mu)$ (Lokshin and Glinskaya, 2009). We account for the effects of unobserved heterogeneity by estimating marginal treatment effects (MTE) that determine the effect of using an improved storage technology on households that are motivated to change their outcomes because of the improved storage technology (Heckman and Vytlacil, 2005; Lokshin and Glinskaya, 2009).

An exclusion restriction is used for better identification of both the ESR and endogenous switching probit models. Selection of the exclusion restriction is guided by economic theory and empirical studies. Di Falco et al. (2011); Shiferaw et al. (2014); Khonje et al. (2015) used information sources such as government extension, farmerto-farmer extension, radio information, market and climate information and distance to inputs as exclusion restrictions. In this study, the presence of an agricultural development or extension agent in the village is used as an exclusion restriction based on two reasons. First, extension services are the primary source of knowledge and information about new and improved technologies for farmers especially when the cost of information and knowledge is prohibitive (Genius et al., 2014; Krishnan and

4 In the formulation of the endogenous switching probit model, $Z_{i}$ represent a vector of variables which will determine a switch between the regimes. 
Patnam, 2014). In addition to its role in developing the skills and knowledge of farmers to adopt new and improved technologies, extension could play a vital role in the facilitation of linkages with other institutional support services such as input supply, output marketing, and credit. Second, development or extension agents are usually assigned at the administrative level and their assignment is less likely to be influenced by households' behavior. Besides, the presence of extension agent in the village or community is independent of the farmer's decision to use an improved storage technology (Kadjo et al., 2013).

A falsification test for admissibility of the exclusion restriction confirms that it is a plausible instrument since the variable is significantly correlated with use of improved storage technologies $(p<0.01)$, but not correlated with the outcomes for non-user households (table C.5, Appendix C) (Di Falco et al., 2011). We conduct additional tests for the strength and validity of the instrument (table C.6). Wooldridge's (1995) score which tests for whether the instrument is uncorrelated with the error term of the outcome equation fails to reject the null hypothesis that the instrument is valid and excludable from the outcome equation. The Anderson canonical correlation statistic rejects the null hypothesis of under-identification of the model at less than $1 \%$ an indication that the excluded instrument is relevant (Baum et al., 2007). We also estimated the Cragg-Donald chi-square statistic which also rejects the null of weak identification at less than $1 \%$ level of significance. Furthermore, we assessed weak-instrument robust inference using the Anderson-Rubin's test (Baum et al., 2007) which also confirmed the strength of the selection instrument.

\subsubsection{Matching and Inverse probability weighting methods}

We compare the ESR model results with results from Kernel-based matching and inverse probability weighting estimates. Kernel matching is a non-parametric matching estimation that uses weighted averages of all individuals in the control group to construct counterfactual outcomes of a treated observation (Heckman et al., 1998). It minimizes the risk of bad matches that would arise from using nearest neighbor matching methods (Caliendo and Kopeinig, 2008). Inverse probability weighting (IPW) is another method for adjusting for confounding when using observational data (Curtis et al., 2007; Donald et al., 2014). Unlike matching techniques, IPW assigns greater weights to control groups with higher estimated probabilities of selection into the treatment (Handouyahia et al., 2013). Another attractive feature of IPW is its efficiency.

Various diagnostics are undertaken to check the quality of the matching. A visual inspection of the density distribution of the propensity scores and the overlap in the distribution of the propensity scores (figure C.I, Appendix C) indicates that the common support condition is satisfied. Diagnostic tests also show a fairly low pseudo $R^{2}$, high total bias reduction and insignificant p-values of the LR test after matching (Table C.7, Appendix C), which provides evidence that the proposed specification 
is successful in terms of balancing the distribution of the covariates between the improved storage technology user and non-user groups. Estimates from propensity score matching are sensitive to hidden bias or unobserved factors. The thresholds at which the estimates are sensitive to such bias are computed using the Rosenbaum bounds (rbounds) for continuous outcomes and MH bounds (mhbounds) for binary outcomes (see Becker and Caliendo (2007)). The results are summarized in Table C.8 (Appendix C).

\subsubsection{Data}

This study uses data from Ethiopian Socioeconomic Survey (ESS), a nationally representative survey of rural households of Ethiopia from 2013/14. The data is collected under the Living Standards Measurement Study-Integrated Surveys on Agriculture (LSMS-ISA) initiative of the World Bank in collaboration with Central Statistical Authority of Ethiopia. The data were collected in three rounds of visits to the households. The first round was carried out in September and October 2013 and collected information on post-planting agriculture activities. The second round was conducted in November-December 2013 to complete the livestock questionnaire. Information on post-harvest agriculture and household characteristics were collected during the third round that took place from February-April 2014. The survey collected detailed information on demographics, health (including anthropometric measurements for children), food and non-food consumption expenditure, food security, shocks, and safety nets, land holding, crop harvest, storage, and utilization. In addition to the household data, the survey solicited community level information on access to services such as weekly markets, cooperatives, financial institutions, irrigation schemes and the presence of agricultural development or extension agent. The household location is geo-referenced which enables linking the household data with geographic data sets including climatic variables (rainfall and temperature) and geographic characteristics such as distance to main markets, nearest road, and population centers.

The LSMS-ISA dataset lacks information on some key variables which restricts the scope of our analysis. There is no data on the costs and source markets of the storage technologies, the length of the storage period, seasonal price data for crops, timing of adoption or dis-adoption of storage technologies and whether they were promoted or donated. We did not report postharvest loss in our analysis since most of the respondents did not respond to the question. ${ }^{5}$ The analysis is done based on a sample

5 Some of the questions in the post-harvest module are not adequate to derive relevant postharvest information such as amount of postharvest loss. There are also data limitations in response as observed by many missing values to some of the postharvest questions including the amount of postharvest loss. Readers can refer the study by Mezgebe et al. (2016). 
of 2,136 rural households, of which 454 are improved storage technologies users and 1,682 are non-users.

\subsubsection{Variables and descriptive statistics}

\subsubsection{Crop storage methods}

The improved crop storage technology variable is constructed from the postharvest agriculture module of the LSMS-ISA data for Ethiopia. Households were asked: "Do you have any of the harvested crop in storage now?" and "What is your main method of storage for this crop?". In this study, improved storage technologies refer to the use of metal silos, air tight drums, modern store or improved locally made structures such as improved granaries (Kaminski and Christiaensen, 2014; Lipinski et al., 2013; Rosegrant et al., 2015). Use of improved storage technology is defined as a binary variable taking a value of 1 for users and o for non-users. Previous studies focus on a single improved storage method and single crop (Bokusheva et al., 2012; Gitonga et al., 2013). Due to data constraints, it is not possible for us to conduct a separate analysis for a single crop or a single crop group. Therefore, we focus on the use of improved storage technologies for food crops including food grains, roots and tubers, and fruits and vegetables. The choice of the food groups is also based on their contribution to household food security and income in the Ethiopian context (Chauvin et al., 2012; H.Gabriel and Hundie, 2006). Although such aggregation might have a limitation since different crop (crop groups) might have different storage properties (e.g. perishability, value), it is also important to learn the effects of the storage technologies to households' food security and welfare since households often use different storage mechanisms for various crops.

Table 4.2 summarizes the main crop storage methods used by the sample households. At the household level, bags, 'gotera' and heaping in the house or unprotected piles are the common non-improved storage methods for food grains. Metal silos are the only improved storage technologies for food grains although they are only used by about $1 \%$ of the households. Airtight drums are the dominant improved storage methods for storing roots crops, followed by sacks or open drums, and locally made structures. Hermetic storage containers such as metal silo or airtight containers offer greater food crop management flexibility under volatile climatic conditions provided that farmers have dried their grain sufficiently (Stathers et al., 2013). Common methods for storing vegetables are sacks/open drum, air tight drum, locally made structures, and unprotected piles. Use of modern storage and improved locally made structures for storing food crops is rare. Overall, the proportion of households who use any improved storage technology for food crops is about $21.3 \%$. This figure falls 
within the $12 \%$ to $74 \%$ range for adoption rate of postharvest innovations reported in Affognon et al. (2015). ${ }^{6}$

Table 4.2: Food storage methods used by sample households

\begin{tabular}{|c|c|c|c|c|}
\hline & \multirow[b]{2}{*}{ Overall use (\%) } & \multicolumn{3}{|c|}{ Use by crop group (\%) } \\
\hline & & Food grains & Roots crops & Vegetables \& fruits \\
\hline \multicolumn{5}{|l|}{ Improved storage } \\
\hline Airtight drum & 20.5 & & $79 \cdot 4$ & 35.6 \\
\hline Improved local structures & 0.04 & & 0.2 & \\
\hline Modern store & 0.1 & & 0.2 & \\
\hline Metal silo & 1.0 & 1.0 & & \\
\hline \multicolumn{5}{|l|}{ Non-improved storage } \\
\hline Bags in house/sacks & 61.8 & 61.0 & 17.6 & 47.8 \\
\hline Gotera $^{a}$ & 33.6 & 35.2 & & \\
\hline Locally made structures & 3.2 & & 8.1 & 16.1 \\
\hline Heaping/unprotected piles & 9.2 & 13.9 & 0.2 & 12.8 \\
\hline Other methods & 23.8 & $25 \cdot 5$ & 3.0 & 6.1 \\
\hline Observations $^{b}$ & 2,136 & 2,038 & 432 & 180 \\
\hline
\end{tabular}

Note: (a) Gotera is a local or traditional grain storage facility in Ethiopia; (b) The statistics for the crop groups is based on the number of households who report storage during the survey. In some cases, the sum of percentages may exceed $100 \%$ since households might use more than one storage method for different crops.

\subsubsection{Outcome variables}

This paper utilizes both objective and subjective measures of food security. This addresses the limitations of previous studies which used a single measure without aligning different measures of food security with the food security dimensions. The key indicator for food security is the household dietary diversity score (HDDS) which is computed as the number of food groups (from 12 food groups) consumed in a week before the survey. ${ }^{7}$ The household dietary diversity score is an attractive proxy indicator for food security and the socio-economic ability of a household as it is highly correlated with caloric, protein and nutrient adequacy, household income and child nutritional status (Swindale and Bilinsky, 2006; Webb et al., 2006). It is used as a proxy

6 Storing well dried crops with effective chemicals (e.g. recommended pesticides) would be improved storage method. In the LSMS-ISA survey, households were asked if they do spray, use chemicals, or other methods to protect the stored crop. However, it is not clearly stated if the chemicals are recommended or not. Existing studies show that farmers often utilize crop protection chemicals which are not recommended (Sheahan and Barrett, 2017). Therefore, we are unable to use the available crop protection data and cannot depict it as an improved crop storage method.

7 The 12 food groups include: (i) cereals, (ii) roots \& tubers, (iii) vegetables, (iv) fruits, (v) meat and poultry, (vi) eggs, (vii) fish and sea food, (viii) pulses, (ix) milk and milk products, (x) oil/fats, (xi) sugar/honey, and (xii) miscellaneous food items. 
for food security (food access) and diet quality (Jones et al., 2014; Maxwell et al., 2014). In addition to the household dietary diversity score, we compute the minimum acceptable diet, a binary variable which takes a value of 1 if the HDDS is greater than or equal to 4, o otherwise (Labadarios et al., 2011). This indicator shows us whether households are consuming diets which offer them some diversity in terms of both macro and micronutrients. The bivariate statistics shows that improved storage users have higher dietary diversity score than non-user households on average. Improved storage users also consume a more diverse diet and the difference is statistically significant (Table $4 \cdot 3$ ).

Other food security indicators that are used in the study include self-reported food insecurity and coping strategies. Such indicators capture household behaviors regarding anxiety and uncertainty over household insecure access or food supply (Coates, 2013; Cordeiro et al., 2012; Maxwell et al., 2014; Swindale and Bilinsky, 2006). The selfreported food insecurity is a dummy variable taking the value of 1 if the household worries that there would be no enough food for the household due to lack of resources and o otherwise. Closely following the existing literature (Coates et al., 2006; Maxwell et al., 2008), we combine the individual coping strategies to construct two indicators of food security: negative change in diet and reduced food intake. Negative changes in diet include strategies where the households have to rely on less preferred foods or limit the variety of foods eaten which corresponds to dietary change. Reduced food intake is very similar to food rationing and is constructed from strategies such as limiting the number of meals taken per day as well as the portion size, restricting consumption of adults so that children can eat, and borrowing food or relying on external help from others. Both negative change in diet and reduced food intake are constructed as binary variables. The proportion of households who reduce their food intake during times of food shortage is found to be significantly higher for improved storage user households than non-user households (Table 4.3).

Per capita food consumption expenditure is the other objective measure of food security. The variable is computed as the total value of food consumed by the household from own production, purchase from the market or from gifts and other sources. Per capita total consumption expenditure is used as an indicator of household welfare (Deaton, 2003; Moratti and Natali, 2012). It is constructed by adding food consumption expenditure and non-food expenditure. Both measures are scaled to per month units and expressed in Ethiopian Birr. As can be seen from Table 4.3, the difference between the two groups in terms of per capita food and total consumption expenditure is not statistically significant.

The nutritional status of under-5 children is measured using anthropometric measures. We used stunting and wasting as indicators of child malnutrition. Stunting is the most important long-term indicator of child nutritional status and wasting is a short term indicator of acute malnutrition (WHO, 1995; Manda et al., 2016; Slavchevska, 
2015). Two indices, height-for-age (HAZ) and weight-for-height (WHZ) were constructed and recorded as a z-score, which describes the number of standard deviations by which the child's anthropometric measurement deviates from the median in the $2006 \mathrm{WHO}$ child growth standards. The $\mathrm{z}$-score cut-off point between -3 and -2 denotes moderate stunting and wasting suggesting moderate undernutrition, and a z-score of less than -3 defines severe stunting or wasting which shows severe undernutrition (WHO, 1997). Our analysis shows that both stunting and wasting are highly prevalent among non-user households. Nonetheless, the difference between users and non-users is not statistically significant.

Table 4.3: Summary statistics of food security and welfare of the sample households

\begin{tabular}{|c|c|c|c|c|c|}
\hline & \multicolumn{2}{|c|}{ Users } & \multicolumn{2}{|c|}{ Non-users } & \multirow[b]{2}{*}{$\mathrm{t}$} \\
\hline & Mean & Std.Dev & Mean & Std. Dev. & \\
\hline \multicolumn{6}{|l|}{ Food and nutriton security } \\
\hline Dietary diversity score & 5.92 & 1.69 & 5.67 & 1.80 & $2.62^{* * *}$ \\
\hline Minimum acceptable diet & 0.93 & & 0.89 & & $2.20^{* *}$ \\
\hline Self-reported food insecurity (\%) & 12.6 & & 12.4 & & 0.11 \\
\hline Per capita food consumption (ETB) & 307.184 & 303.04 & 338.60 & 657.26 & -0.99 \\
\hline Per capita total consumption (ETB) & $459 \cdot 37$ & 415.01 & 506.28 & 902.51 & -1.08 \\
\hline Negative change in diet (\%) & 19.8 & & $17 \cdot 7$ & & 1.03 \\
\hline Reduced food intake (\%) & 20.7 & & 15.2 & & $2.80^{* * *}$ \\
\hline Observations & 454 & & 1,682 & & \\
\hline \multicolumn{6}{|l|}{ Child growth } \\
\hline Child is stunted (\%) & 38.2 & & $41 \cdot 3$ & & -1.04 \\
\hline Child is wasted (\%) & 6.68 & & 9.45 & & -1.63 \\
\hline Observations & 351 & & 1,216 & & \\
\hline
\end{tabular}

Note: ETB is the Ethiopian currency. Analysis of the child nutrition impacts of improved storage is done on the sample of under- 5 children taken from the households. In our sample, about $46 \%$ of the 2,136 sample households do not have children under 5 years of age. ${ }^{*} p<0.10,{ }^{* *} p<0.05,{ }^{* * *} p<0.01$;

Although the mean comparison tests provided an overview of the food security and welfare of improved storage technology user and non-user households, a simple mean comparison of the outcomes is misleading since the two groups might be systematically different in their observed and unobserved characteristics. We account for these concerns by employing estimation strategies that estimate causal effects and control for differences in observed and unobserved characteristics. 


\subsubsection{Choice of explanatory variables}

Variables that would affect the decision to use improved storage technologies and the outcomes were selected based on economic theory, empirical studies on technology adoption, and data availability. The main variables of interest are mainly drawn from the literature on adoption and impact of agricultural innovations (Asfaw et al., 2012; Coromaldi et al., 2015; Manda et al., 2016; Di Falco et al., 2011; Khonje et al., 2015; Mutenje et al., 2016; Shiferaw et al., 2014; Cunguara and Darnhofer, 2011) and postharvest economics (Affognon et al., 2015; Bokusheva et al., 2012; Gitonga et al., 2013; Kaminski and Christiaensen, 2014; Stathers et al., 2013). Factors that commonly influence the adoption of agricultural innovations, food security, and welfare include household characteristics (gender of the household head, age, and education of the household head, household size), and household wealth indicators (livestock ownership, farm size, and asset ownership, off or non-farm income opportunities, etc). Other factors include access to credit or finance, information, social safety nets, access to markets and infrastructure. Also included are production shocks (if the household reports crop damage due to drought) and market shocks (whether the household reports a rise in the prices of food items). The average annual rainfall and temperature patterns, as well as those from the wettest quarter, are introduced to account for the effect of pre and post-harvest rainfall and temperature patterns (Kaminski and Christiaensen, 2014). We also controlled for the effect of child characteristics (gender and age) and access to improved water sources and sanitation on child nutritional status (Manda et al., 2016). We used the same set of variables in the endogenous switching regressions, propensity score matching and inverse probability weighting estimations. Description of the main explanatory variables and the descriptive statistics is provided in Table C.1 (Appendix C).

\subsection{RESULTS AND DISCUSSION}

Results of the econometric models are presented in the succeeding sections. We first discuss the results of the first stage (probit) results of the endogenous switching regression which estimates the determinants of household's decision to use improved storage technologies (Table C.2, Appendix C).

\subsubsection{Drivers of improved storage technology use}

The statistical significance and sign of the estimated coefficients of the determinants of improved storage technology use (Table C.2) are broadly consistent with the literature (Affognon et al., 2015). The probability to use improved storage technologies increases with age of the household head. Age could be a proxy for experience and experienced farmers are more likely to be knowledgeable about the problem of and potential solutions for postharvest storage losses and would, therefore, be more proactive in 
using improved storage technologies (Gitonga et al., 2013). The probability of using improved storage technologies increases with distance from the main market. This suggests that farm households located far from markets might rely on the use of improved storage technologies in order to be less dependent on markets for food.

The probability to use improved storage technologies falls with the presence of large weekly market in the community. This indicates the role of improved storage as a substitute for local markets. The positive coefficient for distance to administration may signify that remote households use improved storage technologies in order to reduce dependence on external support for food. The decision to use improved storage technologies is negatively correlated with distance to the major road. This could be due to two possible reasons. One, households located farther from the major road might be less likely to get access to information about postharvest loss mitigation alternatives. Second, farming households with limited access to infrastructure such as passable roads might have less incentive to produce and store for markets. Hence, they would rather rely on traditional storage techniques to store food for consumption.

Access to extension services is positively correlated with improved storage technology use which is consistent with results from a previous study (Adegbola et al., 2011). Improved storage technology use is also positively correlated with access to finance and non-farm business ownership. This is expected since non-farm income opportunities and access to finance relax capital or income constraints which are the major factors that deter the use of improved storage technologies (Gitonga et al., 2013). However, social transfers have a negative correlation, possibly since transfer programs are often a supplement to food availability and would discourage investments in improved storage (Gitonga et al., 2013; Sheahan and Barrett, 2017). Improved storage technology use is also positively correlated with the presence of a village irrigation scheme. Access to irrigation raises production which may increase the demand for improved storage facilities that allow farmers to benefit from inter-temporal price arbitrage (World Bank et al., 2011).

Mean annual temperature is positively correlated with the use of improved storage technology. This could be possible since an increase in temperature could affect postharvest activities. An increase in temperature would lead to a quicker reproduction of insect pests and fungi which would corrupt the stored produce (Stathers et al., 2013). An increase in temperature could also reduce the effectiveness of informal safety nets and induce seasonal price volatility that would necessitate the use of improved storage methods (ibid). An increase in the mean temperature of the wettest quarter is negatively correlated with the use of improved storage technology. A possible explanation is that the mean temperature of the wettest quarter would exert stress on crops due to crop moisture loss. This would result in crop damage which reduces the demand for improved storage technologies during harvests. There is a positive and statistically significant correlation between annual rainfall and improved storage technology use. 
This is not surprising since production would increase with rainfall and this would induce demand for improved storage technology.

\subsubsection{Endogenous switching regression results}

\subsubsection{Endogenous switching regression: Treatment Effects}

The full information maximum likelihood (FIML) estimates of the ESR model are presented in Tables 4.4 and C.3 in Appendix C. The Wald tests confirm the joint significance of the error correlation coefficients in the selection and outcome equations (Table C.3). Significant correlation coefficients of the selection equation and some of the outcome equations for improved storage technology users indicate the presence of self-selection in the use of improved storage technologies. This also suggests that improved storage technology use had a significant impact on the corresponding outcomes among users, and users would have gained greater benefits from improved storage technology use than non-users had non-users chosen to use (Alene and Manyong, 2007). Insignificant correlation coefficients of the improved storage technology use e and outcome equations for non-users imply that users and non-users have the same values of outcomes given their observed characteristics. However, the differential effects of improved storage technologies on the two groups is possibly due to initial differences in unobserved factors (ibid).

The correlation coefficients between the error terms of the improved storage use and food security outcome equations have similar signs. This suggests the presence of hierarchal sorting where improved storage technology users have above average returns irrespective of use, but $\mathrm{t}$ are better off using improved storage technologies, while non-users have below average returns regardless of use but are better off not using improved storage technologies (Alene and Manyong, 2007; Fuglie and Bosch, 1995). In the welfare equation, the error correlation coefficients alternate in signs an indication that improved storage technology use is driven by comparative advantage where improved storage technology users have above average returns from using and non-users have above average returns from non-use (Alene and Manyong, 2007; Fuglie and Bosch, 1995). Table 4.4 presents the expected values of the various outcomes under the actual and counterfactual conditions and the resulting treatment effects. 
4. FOOD STORAGE INNOVATIONS, FOOD SECURITY AND WELFARE

Table 4.4: Endogenous switching regression based treatment effects

\begin{tabular}{llccl}
\hline \hline \multirow{2}{*}{ Outcomes } & Household type & \multicolumn{2}{c}{ Decision stage } & \multirow{2}{*}{ ATEs } \\
\cline { 3 - 4 } & & & \\
\cline { 3 - 4 } Dietary diversity score & User (ATT) & 5.92 & 5.67 & $0.25(0.05)^{* * * *}$ \\
& Nonuser (ATU) & 7.66 & 5.65 & $2.01(0.05)^{* * *}$ \\
& Heterogeneous effects & -1.74 & 0.02 & -1.76 \\
Per capita food consumption & User (ATT) & 5.44 & 5.45 & $-0.01(0.02)$ \\
& Nonuser (ATU) & 5.45 & 5.44 & $0.01(0.02)$ \\
& Heterogeneous effects & -0.01 & 0.01 & -0.02 \\
Per capita total consumption & User households (ATT) & 5.88 & 5.91 & $-0.03(0.02)$ \\
& Nonuser (ATU) & 6.00 & 5.91 & $0.10(0.02)^{* * *}$ \\
& Heterogeneous effects & -0.12 & -0.00 & -0.13 \\
\hline \hline
\end{tabular}

Note: ATT - Average Treatment Effect on the Treated, ATU -Average Treatment Effect on the Untreated, ATE - Average Treatment Effects; Standard errors in parentheses; ${ }^{*} p<0.10,{ }^{* *} p<0.05,{ }^{* * *} p<0.01$; both per capita food consumption expenditure and per capita total consumption expenditure are log transformed.

The results from the ESR models show that use of improved storage technologies increases household dietary diversity. The expected dietary diversity score for user households is 5.92 while it is 5.65 for non-users. In the counterfactual case, users would have obtained a dietary diversity score of 5.67 had they decided not to use. Hence, improved storage technology use increased the dietary diversity score by 0.25 points for users. In the counterfactual case, non-user households would have increased the dietary diversity score by about 2.0 points had they used. Improved storage technologies can increase dietary diversity by reducing postharvest loss, encouraging farmer's production of diverse crops and enabling households to benefit from price seasonality and ultimately purchase different foods (Omotilewa et al., 2016). This result is consistent with other studies that find a positive link between improved storage technologies and food security (Gitonga et al., 2013; Snapp and Fisher, 2015). The impact of improved storage technologies on per capita food consumption expenditure and per capita total consumption expenditure is insignificant for users. However, non-users would have had higher per capita consumption expenditure had they decided to use. Basu and Wong (2015) also find that improved food storage technologies had a non-significant impact on staple consumption in Indonesia. Cunguara and Darnhofer (2011) also find that improved granaries have insignificant impact on household income in Mozambique.

The negative base heterogeneity effect for the outcomes implies that user households have lower food security and welfare possibly due to unobservables. This could also be the result of targeted and donated storage technologies (if any). After adjusting 
for the potential heterogeneity in the sample, there is evidence that user households tend to have benefits lower than the average irrespective of use, but they are better off using than not using (Di Falco et al., 2011). The negative transitional heterogeneity effect also indicates that the impact would have been higher for non-user households had they decided to use.

Table C.3 shows differences in the coefficients of the explanatory variables in the outcome equations of user and non-user households, which illustrates the presence of heterogeneity in the sample (Di Falco et al., 2011). Overall, the household demographic characteristics are important determinants of the outcomes for both user and non-user households. Some of the explanatory variables have a heterogeneous association with the outcomes of user and non-user households. For non-user households, dietary diversity score increases when the head is male but decreases with the age of the head. However, gender and age of the household head are not correlated to the dietary diversity of user households. Among non-user households, primary education or less for the household head is associated with lower dietary diversity. Among user households, post-primary education for the household head is correlated with higher dietary diversity. Although user and non-user household heads have the same average education, this does not necessarily mean that the education has the same effect on outcomes for both groups of households as the quality of education may vary across the groups. Kaminski and Christiaensen (2014) also show that primary education alone is not sufficient to decrease post-harvest loss. Livestock holdings and mobile phone ownership are positively correlated with food security regardless of improved storage technology use. However, farm size and asset holdings are positively correlated with the dietary diversity of non-user households.

Interestingly, the presence of a large weekly market in the community is positively correlated with the dietary diversity of non-user households. This is possible since non-users who rely on traditional storage technologies could still need to increase diversity by purchasing foods from local markets. Results also show that distance to a major road is negatively correlated with the dietary diversity of user households. Dietary diversity also decreases with distance to the nearest market for non-user households, but the correlation is insignificant for user households. This provides further evidence that improved storage technologies can improve food security by enhancing the consumption of own production in areas where households do not have access to markets (Carletto et al., 2015; Basu and Wong, 2015). The use of improved storage technologies may also decrease the need for traveling to markets to buy food. Hence, storage innovations not only improve stocks but may decrease transactions costs incurred when purchasing food.

Climatic factors and shocks also have differential associations with the dietary diversity of user and non-user households. Dietary diversity diminishes as mean annual temperature increases for non-users. A possible explanation is that an increase in temperature could lead to the wilting of harvests stored in poor conditions more than 
they would reduce postharvest losses through the lowering of humidity. This would lead to the consumption of less diverse foods. However, dietary diversity is positively associated with the mean temperature of the wettest quarter for non-user households. An increase in the average temperature in the wettest season could counteract the higher humidity that would adversely affect storage conditions. Mean annual rainfall is positively correlated with the dietary diversity of non-user households. An increase in rainfall is often associated with an increase in food production that would increase dietary diversity. The amount of rainfall in the wettest quarter is negatively correlated with dietary diversity of users and non-users, which is unsurprising since large amounts of rainfall during the wettest quarter would adversely affect crop production, increase rotting and pest infestations during storage and impede access to markets due to the poor quality of the roads in rural areas. Exposure to production shocks is negatively correlated with the dietary diversity of user households. A possibility is that households who experience severe drought may end up storing only a few staple crops which would reduce dietary diversity. Market shocks reduce dietary diversity for non-user households however the association is insignificant for user households. Hence, improved storage technologies can safeguard households from market shock-induced food insecurity.

\subsubsection{Endogenous Switching Probit model results}

Results of the FIML endogenous switching probit model which estimated the impact of improved storage technology use on binary food security outcomes are provided in Table $4 \cdot 5 \cdot{ }^{8}$

Results show that the use of improved storage technologies increases the probability of consuming a minimum acceptable diet by about 7 percentage points for user households than in the counterfactual scenario of non-use. Non-user households would have increased the probability of meeting a minimum acceptable diet by about 6 percentage points had they used improved storage technologies. Use of improved storage technology lowers the probability of reporting food insecurity by 20 percentage points. This is consistent with the findings of Basu and Wong (2015), Bokusheva et al. (2012), and Gitonga et al. (2013). The use of improved storage technology also reduces the likelihood of negative change in diet by 89 percentage points. This indicates that households who use improved storage facilities are less likely to consume food items of less preference or to reduce the variety of foods consumed than in the counterfactual of non-use. However, we find that the use of improved storage technologies increases the probability of households reducing food intake during periods of food shortage by 13 percentage points compared to the counterfactual of non-use. This result is counterintuitive for users. It could be that food rationing is not only related to food availability but also to the intrahousehold allocation of food and the

8 Table C.4 (Appendix C) presents the coefficients of the explanatory variables in the endogenous switching probit model for selected binary food security outcomes. 
amount of food stored may not be sufficient to prevent the use of food rationing as a coping strategy. Households using improved storage technologies could also reduce their harvest season consumption in order to raise consumption and also benefit from price increases during the lean season (Basu and Wong, 2015).

Table 4.5: Treatment effects: Endogenous switching probit estimates

\begin{tabular}{lcccc}
\hline \hline \multirow{2}{*}{ Outcomes } & \multicolumn{4}{c}{ Treatment Effects } \\
\cline { 2 - 5 } & ATT & ATU & ATE & MTE \\
\hline Household food (in) security & & & & \\
Minimum acceptable diet & $0.07^{* * *}$ & $0.06^{* * *}$ & $0.06^{* * *}$ & $0.05^{* * *}$ \\
Self-reported food insecurity & $-0.20^{* * *}$ & $-0.06^{* * *}$ & $-0.09^{* * *}$ & $-0.03^{* * *}$ \\
Negative change in diet & $-0.89^{* * *}$ & $-0.10^{* * *}$ & $-0.27^{* * *}$ & $0.05^{* * *}$ \\
Reduced food intake & $0.13^{* * *}$ & $-0.09^{* * *}$ & $-0.04^{* * *}$ & $-0.04^{* * *}$ \\
Child growth & & & & \\
Child stunting & $-0.33^{* * *}$ & $-0.05^{* * *}$ & $-0.11^{* * *}$ & $-0.08^{* * *}$ \\
Child wasting & 0.00 & $-0.01^{* *}$ & $-0.01^{* * *}$ & 0.00 \\
\hline \hline
\end{tabular}

Note: ATT - Average Treatment Effect on the Treated, ATU - Average Treatment Effect on the Untreated, ATE - Average Treatment Effect, and MTE - Marginal Treatment Effect; Bootstrapped standard errors; ${ }^{*} p<0.10,{ }^{* *} p<0.05,{ }^{* * *} p<0.01$.

We further estimate the impact of improved storage technologies on child nutritional status as measured by the incidence of stunting and wasting. Interestingly, use of improved storage technologies reduces the incidence of under- 5 child stunting by about 33 percentage points compared to the counterfactual scenario of non-use. The reduction in child stunting among users can be realized through an increase in the consumption of food from own production particularly during market failures (Slavchevska, 2015). Improved storage technologies can reduce malnutrition by ensuring food availability and access to food during the lean season when stocks are depleted and food prices are high (Vaitla et al., 2009). The use of improved storage technology does not have a significant impact on under-5 child wasting for user households. However, it would have reduced wasting by 1 percentage point for non-user households had they decided to use improved storage technologies.

\subsubsection{Comparing results across various estimation methods}

Estimates from the ESR models are compared with estimates obtained using kernelbased matching and IPW methods. Table 4.6 summarizes the average treatment effects from the various techniques. 
4. FOOD STORAGE INNOVATIONS, FOOD SECURITY AND WELFARE

Table 4.6: Comparing results from alternative specifications (ATT)

\begin{tabular}{lccc}
\hline \hline Outcomes & ESR & Kernel matching & IPW \\
\hline Dietary diversity score & $0.25^{* * *}$ & $0.22^{* *}$ & $0.24^{* *}$ \\
Minimum acceptable diet & $0.07^{* * *}$ & $0.04^{* *}$ & $0.04^{* *}$ \\
Per capita food consumption & -0.01 & $0.10^{* *}$ & $0.10^{* *}$ \\
Per capita total consumption & 0.02 & $0.08^{*}$ & $0.08^{* *}$ \\
Self-reported food insecurity & $-0.20^{* * *}$ & -0.01 & -0.01 \\
Negative change in diet & $-0.89^{* * *}$ & 0.00 & 0.00 \\
Reduced food intake & $0.13^{* * *}$ & 0.04 & $0.04^{*}$ \\
Child stunting & $-0.33^{* * *}$ & $-0.07^{*}$ & -0.06 \\
Child wasting & 0.00 & -0.02 & -0.02 \\
\hline \hline
\end{tabular}

Note: ${ }^{*} p<0.10,{ }^{* *} p<0.05,{ }^{* * *} p<0.01$

Overall, the results of the propensity score matching and IPW are fairly consistent and are similar to ESR in the direction/sign of impacts. The results indicate that improved storage technologies have a positive impact on food security and welfare. However, estimates from propensity score matching and IPW are lower than ESR estimates for most of the indicators. Propensity score matching and IPW are methods that only account for selection on observables and they would understate the magnitude of the effects leading to a downward bias than ESR which also accounts for unobserved heterogeneity. In addition, the discrepancies in the magnitudes of the effects could also imply that the ESR model is not as biased as the matching techniques.

\section{$4 \cdot 5$ CONCLUSION}

Improved storage innovations could be considered as climate smart technologies that contribute to sustainable food production by reducing postharvest food loss and climate change mitigation. Using nationally representative data from Ethiopia, we analyze the food and nutrition security and welfare impacts of improved storage technologies. We define improved crop storage technologies as technologies that enable households to store crops for long periods of time with little or no storage loss and quality deterioration. Following the approach by similar empirical studies, air tight drums, metal silos, improved locally made structures and modern store are considered as improved storage technologies. Food and nutrition security is assessed using objective and subjective measures such as dietary diversity score, per capita food consumption expenditure, self-reported food insecurity, food related coping strategies and child growth outcomes. Household welfare is measured using per capita total consumption expenditure. Endogenous switching regression models are used to account for unobserved endogeneity and sample selection. The results from our main 
econometric models are contrasted with propensity score matching and inverse probability weighting methods.

Results of the study lead to the following main conclusions. First, improved storage technologies positively affect food and nutrition security by increasing dietary diversity and reducing negative changes in diet, self-reported food insecurity, and child malnutrition. However, the effect on food rationing is positive. The positive impacts on household dietary diversity and child growth suggest that improved storage technologies are not only climate-smart but also nutrition-smart. Although we do not find evidence of significant impact on food and total per capita consumption expenditures, non-user households would have benefited had they used improved storage technologies. Second, observed differences among user and non-user households generate heterogeneous effects on the outcomes across the two groups. In addition, the study provides evidence regarding the barriers to and opportunities for improved food storage technology use. Policy makers need to consider the role of access to public infrastructure, finance, extension, irrigation and climatic factors in enabling or hindering the use of improved food storage technologies. Increased access to institutional support services such as extension, credit, and input supply should be a major part of any effort aimed at promoting the use of improved storage technologies among non-user households.

Future studies could extend the scope of the analysis by using carefully planned household surveys that capture in-depth and detailed data on post-harvest losses, timing and amounts of crop sales, costs and source markets of storage technologies, whether storage technologies were promoted or donated, timing of adoption and disadoption, and seasonal crop prices. Detailed information on storage technology use and crop sales could deepen our understanding of the impact of storage technologies on market participation as one of the channels through which welfare is attained. In addition, future research can examine how the length of storage and amounts of crop stored mediate the impact of improved storage technologies. We also recommend that future studies investigate the impacts on price arbitrage. 
Aakvik, A., Heckman, J. J., and Edward J. Vytlacil (2000). Discrete Outcomes When Responses to Treatment Vary Among Observationally Identical Persons: An Application to Norwegian Vocational Rehabilitation. Technical report.

Abass, A. B., Ndunguru, G., Mamiro, P., Alenkhe, B., Mlingi, N., and Bekunda, M. (2014). Post-harvest food losses in a maize-based farming system of semi-arid savannah area of Tanzania. Journal of Stored Products Research, 57:49-57.

Adegbola, A., Bamishaiye, E., and Olayemi, F. (2011). Factors Affecting the Adoption of the Re-Usable Plastic Vegetable Crate in Three Local Government Areas of Kano State, Nigeria. Asian Journal of Agricultural Sciences, 3(4):281-285.

Affognon, H., Mutungi, C., Sanginga, P., and Borgemeister, C. (2015). Unpacking Postharvest Losses in Sub-Saharan Africa: A Meta-Analysis. World Development, 66:49-68.

Alene, A. D. and Manyong, V. M. (2007). The effects of education on agricultural productivity under traditional and improved technology in northern Nigeria: An endogenous switching regression analysis. Empirical Economics, 32(1):141-159.

Asfaw, S., Shiferaw, B., Simtowe, F., and Lipper, L. (2012). Impact of modern agricultural technologies on smallholder welfare: Evidence from Tanzania and Ethiopia. Food Policy, 37(3):283-295.

Basu, K. and Wong, M. (2015). Evaluating seasonal food storage and credit programs in east Indonesia. Journal of Development Economics, 115:200-216.

Baum, C. F., Schaffe, M. E., and Schaffe, M. E. (2007). Enhanced routines for instrumental variables/generalized method of moments estimation and testing. The Stata Journal, 7(4):465-506.

Becker, S. O. and Caliendo, M. (2007). Sensitivity analysis for average treatment effect. The Stata Journal, 7(1):71-83.

Besley, T. and Case, a. (2000). Unnatural Experiments? Estimating the Incidence of Endogenous Policies. The Economic Journal, 110(467):F672-F694.

Bokusheva, R., Finger, R., Fischler, M., Berlin, R., Marín, Y., Pérez, F., and Paiz, F. (2012). Factors determining the adoption and impact of a postharvest storage technology. Food Security, 4:279-293. 
Caliendo, M. and Kopeinig, S. (2008). Some practical guidance for the implementation of propensity score matching. Journal of Economic Surveys, 22(1):31-72.

Carletto, G., Ruel, M., Winters, P., and Zezza, A. (2015). Farm-Level Pathways to Improved Nutritional Status: Introduction to the Special Issue. Journal of Development Studies, 51(8):945-957.

Carter, D. W. and Milon, J. W. (2005). Price Knowledge in Household Demand for Utility Services. Land Economics, 81(2):265-283.

Chaboud, G. and Daviron, B. (2017). Food losses and waste: Navigating the inconsistencies. Global Food Security, 12(November 2016):1-7.

Chauvin, N. D., Mulangu, F., and Porto, G. (2012). Food Production and Consumption Trends in Sub-Saharan Africa: Prospects for the Transformation of the Agricultural Sector.

Clougherty, J. and Duso, T. (2015). Correcting for Self-selection Based Endogeneity in Management Research: A Review and Empirical Demonstration.

Coates, J. (2013). Build it back better: Deconstructing food security for improved measurement and action. Global Food Security, 2(3):188-194.

Coates, J., Frongillo, E. a., Rogers, B. L., Webb, P., Wilde, P. E., and Houser, R. (2006). Commonalities in the experience of household food insecurity across cultures: what are measures missing? Journal of Nutrition, 136(5):1438S-1448S.

Conteh, A. M. H., Yan, X., and Moiwo, J. P. (2015). The determinants of grain storage technology adoption in sierra leone. Cahiers Agricultures, 24(1):47-55.

Cordeiro, L. S., Wilde, P. E., Semu, H., and Levinson, F. J. (2012). Household Food Security Is Inversely Associated with Undernutrition among Adolescents from Kilosa, Tanzania. The Journal of Nutrition, 142:1741-1747.

Coromaldi, M., Pallante, G., and Savastano, S. (2015). Adoption of modern varieties, farmers' welfare and crop biodiversity: Evidence from Uganda. Ecological Economics, 119:346-358.

Cunguara, B. and Darnhofer, I. (2011). Assessing the impact of improved agricultural technologies on household income in rural Mozambique. Food Policy, 36(3):378-390.

Curtis, L. H., Hammill, B. G., Eisenstein, E. L., Kramer, J. M., and Anstrom, K. J. (2007). Using inverse probability-weighted estimators in comparative effectiveness analyses with observational databases. Medical care, 45(10):S103-Sio7.

de Janvry, A., Dustan, A., and Sadoulet, E. (2010). Recent advances in impact analysis methods for ex-post impact assessments of agricultural technology: Options for the cgiar. Unpublished working paper, University of California-Berkeley. 
Deaton, A. (2003). Household Surveys, Consumption, and the Measurement of Poverty. Economic Systems Research, 15(2):135-159.

Dethier, J.-J. and Effenberger, A. (2012). Agriculture and development: A brief review of the literature. Economic Systems, 36(2):175-205.

Di Falco, S., Veronesi, M., and Yesuf, M. (2011). Does Adaptation to Climate Change Provide Food Security? A Micro-Perspective from Ethiopia. American Journal of Agricultural Economics, 93(3):829-846.

Donald, S. G., Hsu, Y. C., and Lieli, R. P. (2014). Inverse probability weighted estimation of local average treatment effects: A higher order MSE expansion. Statistics and Probability Letters, 95:132-138.

FAO (2011). Global food losses and food waste. Extent, Causes and Prevention. Technical report.

Foster, A. D. and Rosenzweig, M. R. (2010). Microeconomics of technology adoption. Annu. Rev. Econ., 2(1):395-424.

Fuglie, K. O. and Bosch, D. J. (1995). Economic and Environmental Implications of Soil Nitrogen Testing: A Switching-Regression Analysis. American Journal of Agricultural Economics, 77(November):891-900.

Genius, M., Koundouri, P., Nauges, C., and Tzouvelekas, V. (2014). Information transmission in irrigation technology adoption and diffusion: Social learning, extension services, and spatial effects. American Journal of Agricultural Economics, 96(1):328344.

Gitonga, Z. M., De Groote, H., Kassie, M., and Tefera, T. (2013). Impact of metal silos on households' maize storage, storage losses and food security: An application of a propensity score matching. Food Policy, 43:44-55.

Handouyahia, A., Haddad, T., and Eaton, F. (2013). Kernel matching versus inverse probability weighting: a comparative study. International Journal of Mathematical, Computational, Physical, Electrical and Computer Engineering, 7(8):16-31.

Heckman, J., Tobias, J., and Vytlacil, E. (2001). Four Parameters of Interest in the Evaluation of Social Programs. Southern Economic Journal, 68(2):210-223.

Heckman, J. J. (1986). Sample Selection Bias as a Specification Error. Econometrica, 47(1):153-161.

Heckman, J. J. . and Vytlacil, E. (2005). Structural Equations, Treatment Effects and Econometric Policy Evaluation. Econometrica, 73(3):669-738.

Heckman, J. J., Ichimura, H., and Todd, P. (1998). Matching as an Econometric Evaluation Estimator. Review of Economic Studies, 65(2):261-294. 
H.Gabriel, A. and Hundie, B. (2006). Farmers' Post-Harvest Grain Management Choices under Liquidity Constraints and Impending Risks: Implications for Achieving Food Security Objectives in Ethiopia. In International Association of Agricultural Economists, Gold Goast, Australia, Ausgust 12-18, 2006, pages 1 - 17 .

Hodges, R. J., Buzby, J. C., and Bennett, B. (2011). Postharvest losses and waste in developed and less developed countries: opportunities to improve resource use. The Journal of Agricultural Science, 149(S1):37-45.

Hodges, R. J. and Stathers, T. E. (2013). Facing the Food Crisis: How African Smallholders Can Reduce Postharvest Cereal Losses by Supplying Better Quality Grain. Outlooks on Pest Management, 24(5):217-221.

Jones, A. D., Shrinivas, A., and Bezner-Kerr, R. (2014). Farm production diversity is associated with greater household dietary diversity in Malawi: Findings from nationally representative data. Food Policy, 46(November):1-12.

Kadjo, D., Ricker-Gilbert, J., Alexande, C., and Tahirou, A. (2013). Effects of Storage Losses and Grain Management Practices on Storage: Evidence from Maize Production in Benin. In Agricultural \& Applied Economics Association's 2013 AAEA E CAES Joint Annual Meeting, pages 1-37, Washington, D.C.

Kaminski, J. and Christiaensen, L. (2014). Post-harvest loss in sub-Saharan Africawhat do farmers say? Global Food Security, 3(3-4):149-158.

Khonje, M., Manda, J., Alene, A. D., and Kassie, M. (2015). Analysis of Adoption and Impacts of Improved Maize Varieties in Eastern Zambia. World Development, 66:695 706.

Krishnan, P. and Patnam, M. (2014). Neighbors and extension agents in ethiopia: Who matters more for technology adoption? American Journal of Agricultural Economics, 96(1):308-327.

Kummu, M., de Moel, H., Porkka, M., Siebert, S., Varis, O., and Ward, P. J. (2012). Lost food, wasted resources: Global food supply chain losses and their impacts on freshwater, cropland, and fertiliser use. Science of the total environment, 438:477-489.

Labadarios, D., Steyn, N. P., and Nel, J. (2011). How diverse is the diet of adult South Africans? Nutrition journal, 10(1):33.

Lee, L.-F. and Trost, R. P. (1978). Estimation of some limited dependent variable models with application to housing demand. Journal of Econometrics, 8(3):357-382.

Lipinski, B., Hanson, C., Lomax, J., Kitinoja, L., Waite, R., and Searchinger, T. (2013). Reducing Food Loss and Waste. Technical Report May, Washington, DC. 
Lokshin, M. and Glinskaya, E. (2009). The effect of male migration on employment patterns of women in Nepal. World Bank Economic Review, 23(3):481-507.

Lokshin, M. and Sajaia, Z. (2004). Maximum likelihood estimation of endogenous switching regression models. The Stata Journal, 4(3):282-289.

Lokshin, M. and Sajaia, Z. (2011). Impact of interventions on discrete outcomes: Maximum likelihood estimation of the binary choice models with binary endogenous regressors. The Stata Journal, 11(3):368-385.

Lybbert, T. J. and Sumner, D. A. (2012). Agricultural technologies for climate change in developing countries: Policy options for innovation and technology diffusion. Food Policy, 37(1):114-123.

Manda, J., Gardebroek, C., Khonje, M. G., Alene, A. D., Mutenje, M., and Kassie, M. (2016). Determinants of child nutritional status in the eastern province of Zambia: the role of improved maize varieties. Food Security, 8:239-253.

Maxwell, D., Caldwell, R., and Langworthy, M. (2008). Measuring food insecurity: Can an indicator based on localized coping behaviors be used to compare across contexts? Food Policy, 33(6):533-540.

Maxwell, D., Vaitla, B., and Coates, J. (2014). How do indicators of household food insecurity measure up? An empirical comparison from Ethiopia. Food Policy, 47(August):107-116.

Mengistu, M. and Garrard., J. (2014). Adaptation and adoption of improved household grain and seed storage in southern and eastern ethiopia. catholic relief services. Catholic Relief Services.

Mezgebe, A. G., Terefe, Z. K., Bosha, T., and Muchie, T. D. (2016). Post-harvest losses and handling practices of durable and perishable crops produced in relation with food security of households in Ethiopia : Secondary data analysis. Journal of Stored Products and Postharvest Research, 7(5):45-52.

Miranda, A. and Rabe-Hesketh, S. (2006). Maximum likelihood estimation of endogenous switching and sample selection models for binary, ordinal, and count variables. Stata Journal, 6(3):285-308.

Moratti, M. and Natali, L. (2012). Measuring Household Welfare Short versus long consumption modules Marta.

Mutenje, M., Kankwamba, H., Mangisonib, J., and Kassie, M. (2016). Agricultural innovations and food security in Malawi: Gender dynamics, institutions and market implications. Technological Forecasting and Social Change, 103:240-248. 
Omotilewa, O., Ricker-Gilbert, J., Shively, G., and Ainembabazi, H. (2016). The Effects of Risk Perceptions and Liquidity Constraints on the Storage Decisions of Maize and Legume Producers in Uganda.

Parfitt, J., Barthel, M., and Macnaughton, S. (2010). Food waste within food supply chains: quantification and potential for change to 2050. Philosophical transactions of the Royal Society of London. Series B, Biological sciences, 365(1554):3065-3081.

Parmar, A., Hensel, O., and Sturm, B. (2017). Post-harvest handling practices and associated food losses and limitations in the sweetpotato value chain of southern Ethiopia. NJAS - Wageningen Journal of Life Sciences, 80:65-74.

Premanandh, J. (2011). Factors affecting food security and contribution of modern technologies in food sustainability. Journal of the Science of Food and Agriculture, 91(15):2707-2714.

Rosegrant, M., Magalhaes, E., Valmote-santos, R. A., and Mason-D'Croz, D. (2015). Returns to Investment in Reducing Postharvest Food Losses and Increasing Agricultural Productivity Growth.

Rutten, M. M. (2013). What economic theory tells us about the impacts of reducing food losses and/or waste: implications for research, policy and practice. Agriculture $\mathcal{E}$ Food Security, 2(1):13.

Sheahan, M. and Barrett, C. B. (2017). Ten striking facts about agricultural input use in Sub-Saharan Africa. Food Policy, 67:12-25.

Shiferaw, B., Kassie, M., Jaleta, M., and Yirga, C. (2014). Adoption of improved wheat varieties and impacts on household food security in Ethiopia. Food Policy, 44:272284 .

Shiferaw, B., Prasanna, B. M., Hellin, J., and Bänziger, M. (2011). Crops that feed the world 6. Past successes and future challenges to the role played by maize in global food security. Food Security, 3(3):307-327.

Slavchevska, V. (2015). Agricultural Production and the Nutritional Status of Family Members in Tanzania. The Journal of Development Studies, 51(8):1016-1033.

Snapp, S. S. and Fisher, M. (2015). "Filling the maize basket" supports crop diversity and quality of household diet in Malawi. Food Security, 7:83-96.

Stathers, T., Lamboll, R., and Mvumi, B. M. (2013). Postharvest agriculture in changing climates: Its importance to African smallholder farmers. Food Security, 5(3):361-392.

Swindale, A. and Bilinsky, P. (2006). Household Dietary Diversity Score (HDDS) for measurement of household food access: Indicator guide. Technical report, Food and Nutrition Technical Assistance Project (FANTA), Washington, D.C. 
Bibliography

Tefera, T. (2012). Post-harvest losses in African maize in the face of increasing food shortage. Food Security, 4(2):267-277.

Tefera, T., Kanampiu, F., De Groote, H., Hellin, J., Mugo, S., Kimenju, S., Beyene, Y., Boddupalli, P. M., Shiferaw, B., and Banziger, M. (2011). The metal silo: An effective grain storage technology for reducing post-harvest insect and pathogen losses in maize while improving smallholder farmers' food security in developing countries. Crop Protection, 30(3):240-245.

Vaitla, B., Devereux, S., and Swan, S. H. (2009). Seasonal hunger: A neglected problem with proven solutions. PLoS Medicine, 6(6).

Webb, P., Coates, J., Frongillo, E. A., Rogers, B. L., Swindale, A., and Bilinsky, P. (2006). Measuring Household Food Insecurity: Why It's So Important and Yet So Difficult to Do. The Journal of Nutrition, 136:1404S-1408S.

WHO (1995). Physical Status: The use and Interpretation of Anthropometry.

WHO (1997). Global Database on Child Growth and Malnutrition. Technical report.

World Bank, Natural Resources Institute, and FAO (2011). Missing Food: The Case of postharvest Grain Losses in Sub-Saharan African. Technical Report 60371. 
APPENDIX

Table C.1: Description and summary statistics of the main explanatory variables

\begin{tabular}{|c|c|c|c|c|c|c|}
\hline \multirow[t]{2}{*}{ Variables } & \multirow[t]{2}{*}{ Description } & \multicolumn{2}{|c|}{ Nonusers $(\mathrm{n}=454)$} & \multicolumn{2}{|c|}{ Users $(n=1682)$} & \multirow[b]{2}{*}{$t / \chi^{2}$} \\
\hline & & Mean & Std Dev & Mean & Std Dev & \\
\hline \multicolumn{7}{|l|}{ Household characteristics } \\
\hline Male headed & 1 if the head is male; o if female & 81.0 & & 81.6 & & -0.33 \\
\hline Age of head & Age of the household head in years & 46.00 & 14.69 & 47.6014 .81 & $-2.30 * *$ & \\
\hline Household size & Number of household members & 5.29 & 2.24 & 5.422 .21 & -1.26 & \\
\hline No education (head) & $I$ if the head has no education & 69.25 & & 61.65 & & $3.46^{* * *}$ \\
\hline Primary education & 1 if the head has primary education & $27 \cdot 4$ & & 33.6 & & $-2.82 * * *$ \\
\hline Secondary education & $I$ if head has secondary education & 1.4 & & 2.4 & & -1.43 \\
\hline Post-secondary education & 1 if the head has post-secondary education & 1.0 & & 0.9 & & 0.15 \\
\hline Livestock holding (TLU) & In tropical livestock units & 3.49 & 4.09 & $3 \cdot 37$ & 3.09 & 0.72 \\
\hline Farm size (ha) & Cultivated land in hectare & 1.73 & 1.12 & 1.68 & 1.18 & 0.75 \\
\hline Asset index & Asset index & -0.11 & 1.65 & -0.05 & 1.56 & -0.86 \\
\hline Mobile ownership & I if the head/household own a mobile & 36.7 & & 37.8 & & -0.51 \\
\hline Finance access & $I$ if has access to finance; o otherwise & 23.8 & & 24.7 & & -0.43 \\
\hline Non-farm enterprise & $I$ if owns a non-farm enterprise & 7.4 & & 5.7 & & 1.46 \\
\hline Social transfers & 1 if the household received; o otherwise & 3.72 & & 14.0 & & $-6.89^{* * *}$ \\
\hline Private food transfer & I if the household received; o otherwise & 3.88 & & 3.59 & & 0.33 \\
\hline Private cash transfer & I if the household received; o otherwise & 8.78 & & 8.95 & & -0.12 \\
\hline Distance to road & Distance to major road in $\mathrm{Kms}$ & 16.26 & 17.54 & 13.28 & 13.10 & $4.46^{* * *}$ \\
\hline Distance to market & Distance to nearest market in $\mathrm{Kms}$ & 63.82 & 49.60 & 73.13 & 43.05 & $-4.43^{* * *}$ \\
\hline Distance to admin. center & Distance to administration center, $\mathrm{Kms}$ & 157.23 & 112.57 & 166.90 & 95.18 & $-2.07^{* * *}$ \\
\hline \multicolumn{7}{|l|}{ Shocks and climatic factors } \\
\hline Production shock & I if hh reports; o otherwise & 4.68 & & 4.73 & & -0.05 \\
\hline Market shock & I if hh faces price hikes; o otherwise & 12.2 & & 10.1 & & 1.41 \\
\hline Mean annual temperature & 12 month average in ${ }^{\circ} \mathrm{C}$ & 19.59 & 3.33 & 17.51 & 2.65 & $15.69^{* * *}$ \\
\hline Temp. the wettest quarter & Mean temperature of the wettest quarter in ${ }^{\circ} \mathrm{C}$ & 19.29 & 3.36 & 16.94 & 2.77 & $17.14^{* * *}$ \\
\hline Mean annual rainfall & Average 12 months total RF in mm (in oo's) & 9.17 & 2.59 & 10.07 & 2.21 & $-8.38^{* * *}$ \\
\hline Rainfall of wettest quarter & Rainfall of the wettest quarter in mm (in oo's) & 5.05 & 1.34 & 5.18 & 0.97 & $-2.62 * *$ \\
\hline \multicolumn{7}{|l|}{ Village level variables } \\
\hline Weekly market & 1 if exist ; o otherwise & 48.0 & & $44 \cdot 4$ & & 1.54 \\
\hline Cooperatives & 1 if exist in the community; o otherwise & 16.5 & & 19.1 & & -1.42 \\
\hline Agriextension expert & $I$ if exist ; o otherwise & 94.5 & & $97 \cdot 4$ & & $-3 \cdot 48^{* * *}$ \\
\hline Irrigation scheme & 1 if exist ; o otherwise & 71.9 & & 70.3 & & 0.75 \\
\hline
\end{tabular}

Note: ${ }^{*} p<0.10,{ }^{* *} p<0.05,{ }^{* * *} p<0.01$; Asset index is computed as the score along the first principal component of a principal component analysis applied to households' assets (including farm implements, furniture, electronics, personal items and other assets). For binary outcomes, prevalence rates $(\%)$ are reported. 
Table C.2: Drivers of improved storage technology use

\begin{tabular}{|c|c|c|}
\hline & Coeff. (Std. Er.r) & APE (Std. Err.) \\
\hline Male headed & $0.024(0.093)$ & $0.007(0.022)$ \\
\hline Age of the head & $0.009(0.003) * * *$ & $0.002(0.001) * * *$ \\
\hline Household size & 0.018 (0.017) & $0.004(0.004)$ \\
\hline Below primary education & $-0.102(0.083)$ & $-0.014(0.050)$ \\
\hline Primary education & & $0.011(0.050)$ \\
\hline Secondary education or above & $-0.048(0.194)$ & \\
\hline Farm size & $-0.050(0.032)$ & $-0.012(0.008)$ \\
\hline Asset index & $0.006(0.025)$ & $0.002(0.006)$ \\
\hline Livestock owned & $-0.010(0.013)$ & $-0.002(0.003)$ \\
\hline Non-farm enterprise & $0.193(0.076) * *$ & $0.046(0.019) * *$ \\
\hline Distance to road & $-0.005(0.002) * *$ & $-0.001(0.001) * *$ \\
\hline Distance to admin. center & $0.001(0.000) * * *$ & $0.000(0.000) * * *$ \\
\hline Distance to market & $0.005(0.001) * * *$ & $0.001(0.000) * * *$ \\
\hline Mobile ownership & 0.008 (0.08o) & 0.002 (0.019) \\
\hline Finance access & $0.253(0.080) * * *$ & $0.062(0.019) * * *$ \\
\hline Social transfers & $-0.433(0.154)^{* * *}$ & $-0.106(0.034)^{* * *}$ \\
\hline Private cash transfer & $0.016(0.130)$ & $0.003(0.030)$ \\
\hline Private food transfer & 0.025 (0.197) & $0.006(0.047)$ \\
\hline Weekly market & $-0.318(0.069) * * *$ & $-0.077(0.017)^{* * *}$ \\
\hline Irrigation scheme & $0.185(0.085)^{* *}$ & $0.046(0.021) * *$ \\
\hline Cooperatives & $0.082(0.093)$ & $0.020(0.021)$ \\
\hline Agricultural extension expert & $0.537(0.194)^{* * *}$ & $0.126(0.044)^{* * *}$ \\
\hline Production shock & $-0.093(0.124)$ & $-0.022(0.028)$ \\
\hline Market shock & $0.163(0.113)$ & $0.040(0.027)$ \\
\hline Mean annual temperature & $0.123(0.061)^{* *}$ & $0.030(0.015) * *$ \\
\hline Temperature of wettest quarter & $-0.254(0.059) * * *$ & $-0.062(0.014) * * *$ \\
\hline Mean annual rainfall & $0.007(0.002) * * *$ & $0.017(0.006) * * *$ \\
\hline Rainfall of wettest quarter & -0.005 (0.005) & -0.014 (0.011) \\
\hline Constant & $-0.249(0.369)$ & \\
\hline Observations (N) & 2,136 & 2,136 \\
\hline
\end{tabular}

Note: Average partial effects (APE) reported; Standard errors in parentheses; ${ }^{*} p<0.10,{ }^{* *} p<0.05,{ }^{* * *}$ $p<0.01$. 
Table C.3: Endogenous Switching Regression estimation

\begin{tabular}{|c|c|c|c|c|c|c|}
\hline \multirow[t]{2}{*}{ Variables } & \multicolumn{2}{|c|}{ HDDS } & \multicolumn{2}{|c|}{ Food consumption } & \multicolumn{2}{|c|}{ Total consumption } \\
\hline & Nonusers & Users & Nonusers & Users & Nonusers & Users \\
\hline Male headed & $\begin{array}{l}0.216^{* *} \\
(0.102)\end{array}$ & $\begin{array}{c}0.019 \\
(0.184)\end{array}$ & $\begin{array}{l}0.086^{*} \\
(0.048)\end{array}$ & $\begin{array}{l}-0.155^{* *} \\
(0.076)\end{array}$ & $\begin{array}{c}0.065 \\
(0.043)\end{array}$ & $\begin{array}{l}-0.129^{*} \\
(0.070)\end{array}$ \\
\hline Age of the head & $\begin{array}{c}-0.006^{* *} \\
(0.003)\end{array}$ & $\begin{array}{l}-0.010 \\
(0.010)\end{array}$ & $\begin{array}{l}0.003^{* *} \\
(0.001)\end{array}$ & $\begin{array}{c}0.001 \\
(0.002)\end{array}$ & $\begin{array}{c}0.000 \\
(0.001)\end{array}$ & $\begin{array}{l}-0.001 \\
(0.002)\end{array}$ \\
\hline Household size & $\begin{array}{l}0.041^{* *} \\
(0.020)\end{array}$ & $\begin{array}{l}0.005 \\
(0.040)\end{array}$ & $\begin{array}{c}-0.102^{* * *} \\
(0.009)\end{array}$ & $\begin{array}{c}-0.117^{* * *} \\
(0.017)\end{array}$ & $\begin{array}{c}-0.092^{* * *} \\
(0.008)\end{array}$ & $\begin{array}{c}-0.115^{* * *} \\
(0.015)\end{array}$ \\
\hline Below primary educ. & $\begin{array}{c}-0.943^{* * *} \\
(0.292)\end{array}$ & & $\begin{array}{l}-0.048 \\
(0.090)\end{array}$ & & $\begin{array}{c}-0.155^{* *} \\
(0.078)\end{array}$ & \\
\hline Primary education & $\begin{array}{l}-0.588^{* *} \\
(0.292)\end{array}$ & $\begin{array}{c}0.267 \\
(0.204)\end{array}$ & $\begin{array}{c}0.105 \\
(0.089)\end{array}$ & $\begin{array}{c}0.061 \\
(0.075)\end{array}$ & $\begin{array}{l}-0.012 \\
(0.077)\end{array}$ & $\begin{array}{c}0.075 \\
(0.067)\end{array}$ \\
\hline Second. educ. or above & & $\begin{array}{l}0.968^{* *} \\
(0.380)\end{array}$ & & $\begin{array}{l}0.332^{*} \\
(0.188)\end{array}$ & & $\begin{array}{l}0.357^{* *} \\
(0.167)\end{array}$ \\
\hline Livestock owned & $\begin{array}{l}0.052^{* * *} \\
(0.013)\end{array}$ & $\begin{array}{l}0.111^{* * *} \\
(0.028)\end{array}$ & $\begin{array}{l}0.020^{* * *} \\
(0.006)\end{array}$ & $\begin{array}{c}0.053^{* * *} \\
(0.012)\end{array}$ & $\begin{array}{l}0.019^{* * *} \\
(0.006)\end{array}$ & $\begin{array}{l}0.054^{* * *} \\
(0.011)\end{array}$ \\
\hline Farm size & $\begin{array}{l}0.100^{* *} \\
(0.039)\end{array}$ & $\begin{array}{l}-0.000 \\
(0.073)\end{array}$ & $\begin{array}{l}0.059^{* * *} \\
(0.017)\end{array}$ & $\begin{array}{l}-0.000 \\
(0.029)\end{array}$ & $\begin{array}{l}0.046^{* * *} \\
(0.015)\end{array}$ & $\begin{array}{l}-0.007 \\
(0.026)\end{array}$ \\
\hline Asset index & $\begin{array}{c}0.251^{* * *} \\
(0.038)\end{array}$ & $\begin{array}{c}0.124 \\
(0.078)\end{array}$ & $\begin{array}{c}0.038^{* * *} \\
(0.012)\end{array}$ & $\begin{array}{c}0.067^{* * *} \\
(0.025)\end{array}$ & $\begin{array}{c}0.055^{* * *} \\
(0.011)\end{array}$ & $\begin{array}{c}0.085^{* * *} \\
(0.022)\end{array}$ \\
\hline Non-farm enterprise & $\begin{array}{l}0.161^{*} \\
(0.093)\end{array}$ & $\begin{array}{c}0.009 \\
(0.190)\end{array}$ & $\begin{array}{c}0.057 \\
(0.042)\end{array}$ & $\begin{array}{l}-0.035 \\
(0.064)\end{array}$ & $\begin{array}{l}0.070 \text { * } \\
(0.037)\end{array}$ & $\begin{array}{l}-0.055 \\
(0.057)\end{array}$ \\
\hline Mobile ownership & $\begin{array}{l}0.328^{* * *} \\
(0.097)\end{array}$ & $\begin{array}{l}0.583^{* * *} \\
(0.182)\end{array}$ & $\begin{array}{l}0.150^{* * *} \\
(0.042)\end{array}$ & $\begin{array}{c}0.033 \\
(0.072)\end{array}$ & $\begin{array}{l}0.165^{* * *} \\
(0.038)\end{array}$ & $\begin{array}{c}0.054 \\
(0.062)\end{array}$ \\
\hline Distance to road & $\begin{array}{c}0.002 \\
(0.003)\end{array}$ & $\begin{array}{l}-0.013^{*} \\
(0.007)\end{array}$ & $\begin{array}{l}0.003^{*} \\
(0.001)\end{array}$ & $\begin{array}{l}-0.003 \\
(0.003)\end{array}$ & $\begin{array}{l}0.003^{* *} \\
(0.001)\end{array}$ & $\begin{array}{l}-0.004 \\
(0.002)\end{array}$ \\
\hline Weekly market & $\begin{array}{l}0.245^{* * *} \\
(0.086)\end{array}$ & $\begin{array}{c}0.063 \\
(0.286)\end{array}$ & $\begin{array}{l}-0.037 \\
(0.036)\end{array}$ & $\begin{array}{l}0.150^{* * *} \\
(0.069)\end{array}$ & $\begin{array}{l}-0.029 \\
(0.031)\end{array}$ & $\begin{array}{l}0.145^{* *} \\
(0.062)\end{array}$ \\
\hline Distance to market & $\begin{array}{l}-0.002^{* *} \\
(0.001)\end{array}$ & $\begin{array}{c}0.001 \\
(0.004)\end{array}$ & $\begin{array}{c}-0.003^{* * *} \\
(0.000)\end{array}$ & $\begin{array}{l}-0.001 \\
(0.001)\end{array}$ & $\begin{array}{c}-0.003^{* * *} \\
(0.000)\end{array}$ & $\begin{array}{l}-0.001 \\
(0.001)\end{array}$ \\
\hline Distance to admin. center & $\begin{array}{l}-0.000 \\
(0.000)\end{array}$ & $\begin{array}{l}-0.001 \\
(0.001)\end{array}$ & $\begin{array}{l}-0.000^{*} \\
(0.000)\end{array}$ & $\begin{array}{c}0.001 \\
(0.000)\end{array}$ & $\begin{array}{l}-0.000^{*} \\
(0.000)\end{array}$ & $\begin{array}{c}0.000 \\
(0.000)\end{array}$ \\
\hline Production shock & $\begin{array}{l}-0.144 \\
(0.121)\end{array}$ & $\begin{array}{c}-0.702^{* * *} \\
(0.237)\end{array}$ & $\begin{array}{c}0.030 \\
(0.052)\end{array}$ & $\begin{array}{l}-0.133 \\
(0.107)\end{array}$ & $\begin{array}{c}0.034 \\
(0.045)\end{array}$ & $\begin{array}{l}-0.113 \\
(0.093)\end{array}$ \\
\hline Market shock & $\begin{array}{l}-0.270^{* *} \\
(0.130)\end{array}$ & $\begin{array}{c}0.128 \\
(0.272)\end{array}$ & $\begin{array}{c}0.057 \\
(0.052)\end{array}$ & $\begin{array}{c}0.076 \\
(0.106)\end{array}$ & $\begin{array}{c}0.063 \\
(0.046)\end{array}$ & $\begin{array}{c}0.038 \\
(0.095)\end{array}$ \\
\hline Mean annual temperature & $\begin{array}{l}-0.151^{* *} \\
(0.071)\end{array}$ & $\begin{array}{l}-0.263 \\
(0.168)\end{array}$ & $\begin{array}{c}0.030 \\
(0.030)\end{array}$ & $\begin{array}{l}-0.050 \\
(0.058)\end{array}$ & $\begin{array}{c}0.029 \\
(0.027)\end{array}$ & $\begin{array}{l}-0.016 \\
(0.052)\end{array}$ \\
\hline Temp. of wettest quarter & $\begin{array}{l}0.172^{* *} \\
(0.068)\end{array}$ & $\begin{array}{c}0.372 \\
(0.236)\end{array}$ & $\begin{array}{c}-0.001 \\
(0.030)\end{array}$ & $\begin{array}{c}0.048 \\
(0.056)\end{array}$ & $\begin{array}{l}-0.004 \\
(0.026)\end{array}$ & $\begin{array}{c}0.023 \\
(0.050)\end{array}$ \\
\hline Mean annual rainfall & $\begin{array}{l}0.019^{* * *} \\
(0.003)\end{array}$ & $\begin{array}{c}0.013 \\
(0.008)\end{array}$ & $\begin{array}{c}0.001 \\
(0.001)\end{array}$ & $\begin{array}{c}0.002 \\
(0.002)\end{array}$ & $\begin{array}{c}0.001 \\
(0.001)\end{array}$ & $\begin{array}{c}0.000 \\
(0.002)\end{array}$ \\
\hline Rainfall of wettest quarter & $\begin{array}{c}-0.032^{* * *} \\
(0.005)\end{array}$ & $\begin{array}{c}-0.045^{* * *} \\
(0.011)\end{array}$ & $\begin{array}{c}-0.014^{* * *} \\
(0.002)\end{array}$ & $\begin{array}{c}-0.022^{* * *} \\
(0.005)\end{array}$ & $\begin{array}{c}-0.012^{* * *} \\
(0.002)\end{array}$ & $\begin{array}{c}-0.018^{* * *} \\
(0.005)\end{array}$ \\
\hline Irrigation scheme & $\begin{array}{c}0.127 \\
(0.097)\end{array}$ & $\begin{array}{c}0.347 \\
(0.286)\end{array}$ & $\begin{array}{c}0.056 \\
(0.044)\end{array}$ & $\begin{array}{l}0.182^{* * *} \\
(0.072)\end{array}$ & $\begin{array}{c}0.052 \\
(0.040)\end{array}$ & $\begin{array}{l}0.166^{* *} \\
(0.065)\end{array}$ \\
\hline
\end{tabular}


Table C.3 ... continued

\begin{tabular}{|c|c|c|c|c|c|c|}
\hline \multirow[t]{2}{*}{ Variables } & \multicolumn{2}{|c|}{ HDDS } & \multicolumn{2}{|c|}{ Food consumption } & \multicolumn{2}{|c|}{ Total consumption } \\
\hline & Nonusers & Users & Nonusers & Users & Nonusers & Users \\
\hline \multirow[t]{2}{*}{ Cooperatives } & 0.080 & -0.055 & -0.029 & 0.001 & 0.007 & -0.009 \\
\hline & $(0.113)$ & $(0.205)$ & $(0.044)$ & (o.o78) & $(0.038)$ & (o.o69) \\
\hline \multirow[t]{2}{*}{ Finance access } & $-0.276^{* *}$ & $-0.513^{*}$ & 0.063 & $-0.135^{* *}$ & 0.046 & $-0.204^{* * *}$ \\
\hline & $(0.115)$ & $(0.264)$ & (o.046) & (o.o66) & (0.041) & (o.o6o) \\
\hline \multirow[t]{2}{*}{ Social transfers } & -0.109 & -0.707 & -0.077 & $-0.421^{* * *}$ & $-0.102^{* *}$ & $-0.358^{* *}$ \\
\hline & $(0.126)$ & $(0.524)$ & (0.054) & (o.144) & (o.049) & (o.146) \\
\hline \multirow[t]{2}{*}{ Private cash transfer } & $0.349^{* *}$ & $0.470^{*}$ & 0.073 & -0.058 & $0.100^{*}$ & -0.029 \\
\hline & $(0.143)$ & $(0.271)$ & $(0.062)$ & $(0.136)$ & $(0.055)$ & $(0.117)$ \\
\hline \multirow[t]{2}{*}{ Private food transfer } & 0.142 & -0.310 & -0.098 & 0.017 & $-0.118^{* *}$ & 0.060 \\
\hline & $(0.243)$ & $(0.361)$ & (o.079) & (0.161) & (0.071) & (0.153) \\
\hline \multirow[t]{2}{*}{ Constant } & $5 \cdot 378^{* * *}$ & $6.302^{* * *}$ & $5.803^{* * *}$ & $6.909^{* * *}$ & $6.456^{* * *}$ & $7 \cdot 344^{* * *}$ \\
\hline & (o.494) & (1.172) & (0.185) & $(0.374)$ & (0.162) & (o.347) \\
\hline \multicolumn{7}{|l|}{ Model diagnosis } \\
\hline Wald $\chi^{2}$ & $443.78^{* * *}$ & & $374.54^{* * * *}$ & & $459 \cdot 79^{* * * *}$ & \\
\hline \multirow[t]{2}{*}{$\sigma_{i}$} & $1.57^{* * *}$ & $1.66^{* * *}$ & $0.68^{* * *}$ & $0.63^{* * *}$ & $0.61^{* * *}$ & $0.56^{* * *}$ \\
\hline & (0.03) & (o.48) & (0.02) & (0.03) & (0.02) & (0.02) \\
\hline \multirow[t]{2}{*}{$\rho_{i}$} & -0.11 & -0.60 & 0.09 & 0.02 & 0.10 & -0.07 \\
\hline & (0.17) & $(0.48)$ & $(0.11)$ & (0.11) & (o.09) & (o.09) \\
\hline Observations & 2136 & & 2136 & & 2136 & \\
\hline
\end{tabular}

Note: Standard errors in parentheses; ${ }^{*} p<0.10,{ }^{* *} p<0.05,{ }^{* * *} p<0.01$. 
Table C.4: Switching probit estimation (selected outcomes)

\begin{tabular}{|c|c|c|c|c|c|c|c|c|}
\hline \multirow[b]{3}{*}{ Male headed } & \multicolumn{4}{|c|}{ Food insecurity } & \multicolumn{4}{|c|}{ Minimum acceptable diet } \\
\hline & \multicolumn{2}{|c|}{ Users } & \multicolumn{2}{|c|}{ Nonusers } & \multicolumn{2}{|c|}{ Users } & \multicolumn{2}{|c|}{ Nonusers } \\
\hline & -0.221 & $(0.232)$ & $-0.477^{* * *}$ & $(0.132)$ & $-0.926^{*}$ & $(0.491)$ & -0.075 & $(0.148)$ \\
\hline Age of the head & $0.020^{* * *}$ & (o.007) & 0.006 & $(0.004)$ & 0.004 & $(0.007)$ & -0.002 & $(0.004)$ \\
\hline Household size & $0.181^{* * *}$ & $(0.050)$ & $0.084^{* * *}$ & $(0.026)$ & -0.013 & $(0.058)$ & $0.078^{* * *}$ & $(0.027)$ \\
\hline Below primary education & & & $0.663^{*}$ & $(0.372)$ & & & 0.006 & $(0.533)$ \\
\hline Primary education & $0.614^{* * *}$ & $(0.231)$ & $0.688^{*}$ & $(0.366)$ & 0.341 & $(0.329)$ & 0.336 & $(0.544)$ \\
\hline Second. educ. or above & -0.554 & (o.664) & & & $7.216^{* * *}$ & $(0.726)$ & & \\
\hline Livestock owned & $-0.226^{* * *}$ & $(0.053)$ & $-0.042^{*}$ & $(0.023)$ & $0.088^{*}$ & $(0.052)$ & 0.023 & $(0.017)$ \\
\hline Farm size & $-0.247^{* *}$ & $(0.120)$ & $-0.311^{* * * *}$ & (0.090) & $0.294^{*}$ & $(0.159)$ & 0.080 & (0.059) \\
\hline Asset index & -0.053 & (o.o86) & -0.121 & (0.106) & $1.298^{* * *}$ & $(0.358)$ & $0.360^{* *}$ & $(0.147)$ \\
\hline Non-farm enterprise & $0.457^{* *}$ & $(0.206)$ & 0.084 & $(0.144)$ & -0.472 & $(0.295)$ & 0.016 & $(0.154)$ \\
\hline Mobile ownership & 0.102 & $(0.232)$ & 0.095 & $(0.134)$ & 0.039 & $(0.386)$ & -0.009 & $(0.160)$ \\
\hline Distance to road & -0.000 & (o.0og) & $-0.010^{* *}$ & $(0.004)$ & -0.014 & (0.010) & $0.007^{*}$ & $(0.003)$ \\
\hline Weekly market & 0.375 & $(0.254)$ & 0.105 & $(0.159)$ & $-0.617^{* *}$ & $(0.252)$ & $0.223^{*}$ & (o.119) \\
\hline Distance to market & $0.011^{* * *}$ & $(0.003)$ & $0.005^{* * *}$ & $(0.002)$ & 0.000 & $(0.004)$ & $-0.006^{* * *}$ & (0.001) \\
\hline Distance to admin. center & 0.001 & (0.001) & 0.001 & (0.001) & -0.002 & $(0.002)$ & 0.000 & (0.001) \\
\hline Production shock & $0.720^{* *}$ & $(0.300)$ & $0.417^{* * *}$ & $(0.154)$ & $-1.287^{* * *}$ & $(0.386)$ & 0.025 & (o.169) \\
\hline Market shock & $0.492^{*}$ & $(0.279)$ & $0.571^{* * *}$ & $(0.176)$ & 0.386 & $(0.342)$ & $-0.549^{* * *}$ & (o.194) \\
\hline Mean annual temperature & 0.227 & (0.166) & $0.380^{* * *}$ & $(0.100)$ & -0.314 & $(0.228)$ & -0.117 & $(0.108)$ \\
\hline Temp. of wettest quarter & $-0.359^{* * *}$ & (0.16o) & $-0.385^{* * *}$ & $(0.085)$ & 0.252 & $(0.243)$ & $0.174^{*}$ & (0.105) \\
\hline Mean annual rainfall & -0.004 & $(0.008)$ & 0.002 & $(0.005)$ & $0.053^{* * *}$ & (0.011) & $0.034^{* * * *}$ & $(0.006)$ \\
\hline Rainfall of wettest quarter & $0.044^{* * * *}$ & $(0.017)$ & 0.004 & (o.0o8) & $-0.079^{* * *}$ & (o.019) & $-0.059^{* * *}$ & (0.010) \\
\hline Irrigation scheme & -0.039 & $(0.233)$ & 0.027 & $(0.143)$ & $0.770^{* *}$ & $(0.348)$ & $0.369^{* *}$ & (o.154) \\
\hline Cooperatives & 0.022 & $(0.272)$ & $-0.685^{* * *}$ & (0.193) & -0.046 & $(0.353)$ & 0.214 & $(0.170)$ \\
\hline Finance access & 0.395 & $(0.241)$ & $0.409^{* * *}$ & $(0.132)$ & $-0.683^{*}$ & $(0.349)$ & $-0.405^{* *}$ & $(0.162)$ \\
\hline Social transfers & -0.560 & $(0.499)$ & 0.114 & $(0.180)$ & $-0.900^{*}$ & $(0.466)$ & 0.031 & (0.174) \\
\hline Private cash transfer & $0.667^{* *}$ & $(0.320)$ & -0.092 & (0.194) & $8.213^{* * *}$ & $(0.860)$ & -0.004 & $(0.224)$ \\
\hline Private food transfer & $0.650^{*}$ & $(0.385)$ & $0.513^{*}$ & $(0.266)$ & 1.279 & $(0.841)$ & 0.099 & $(0.281)$ \\
\hline Constant & $-4.182^{* * *}$ & $(1.053)$ & $-2.436^{* *}$ & $(0.967)$ & $3.020^{* *}$ & $(1.418)$ & -0.117 & $(0.704)$ \\
\hline Wald $\chi^{2}$ & $201.98^{* * *}$ & & & & $201.61^{* * *}$ & & & \\
\hline$\rho_{i j}$ & 0.408 & $(0.4719)$ & 0.505 & $(0.491)$ & 0.200 & $(0.519)$ & -0.190 & $(0.154)$ \\
\hline Observations & 2136 & & & & 2136 & & & \\
\hline
\end{tabular}

Note: Standard errors in parentheses; ${ }^{*} p<0.10,{ }^{* *} p<0.05,{ }^{* * *} p<0.01$. 
Table C.5: Test on the validity of the selection instrument (parameter estimates)

\begin{tabular}{lcccc}
\hline \hline & $(1)$ & $(2)$ & $(3)$ & $(4)$ \\
\hline Variables & Improved storage & HDDS & MAD & Change in diet \\
\hline Agri. extension & $0.514^{* * *}$ & -0.036 & -0.208 & 0.337 \\
& $(0.179)$ & $(0.187)$ & $(0.282)$ & $(0.212)$ \\
Other controls & YES & YES & YES & YES \\
Constant & -0.274 & $4.934^{* * *}$ & $1.172^{*}$ & $-1.748^{* * *}$ \\
& $(0.399)$ & $(0.402)$ & $(0.672)$ & $(0.467)$ \\
Wald test & $289.71^{* * *}$ & & $223.39^{* * *}$ & $173.40^{* * *}$ \\
F & & $18.47^{* * *}$ & & \\
\hline Observations & 2,136 & 1,682 & 1,682 & 1,682 \\
\hline \hline
\end{tabular}

Note: (1) Probit model (Pseudo $R^{2}=0.16$ ); (2) HDDS - Household dietary diversity score, Ordinary least squares $\left(R^{2}=0.23\right)$. (3) MAD - Minimum Acceptable Diet, Probit model (Pseudo $R^{2}=0.19$ ); (4) Probit model (Pseudo $R^{2}=0.11$ ); ${ }^{*} p<0.10,{ }^{* *} p<0.05,{ }^{* * *} p<0.01$; Standard errors in parentheses. All control variables are included in the models but parameters are not reported to save space.)

Table C.6: Additional tests for the exclusion restriction

\begin{tabular}{llc}
\hline \hline Test & Null hypothesis/Test type & Test results \\
\hline Durbin test & Exclusion instrument is exogenous & $\mathrm{F}=0.003, \mathrm{p}=0.962$ \\
Wu-Hausman test & Exclusion instrument is exogenous & $\mathrm{F}=0.002, \mathrm{p}=0.962$ \\
Wooldridge's score test & Exclusion instrument is exogenous & $\chi^{2}=0.003, p=0.959$ \\
Anderson canonical correlation statistic & Underidentification & $\mathrm{LR}=8.32, \chi_{p}^{2}=0.004$ \\
Cragg-Donald statistic & Underidentification & $\chi^{2}=8.16, p=0.004$ \\
Anderson-Rubin's & Weak instrument robust test & $\chi^{2}=0.01, p=0.914$ \\
\hline \hline
\end{tabular}



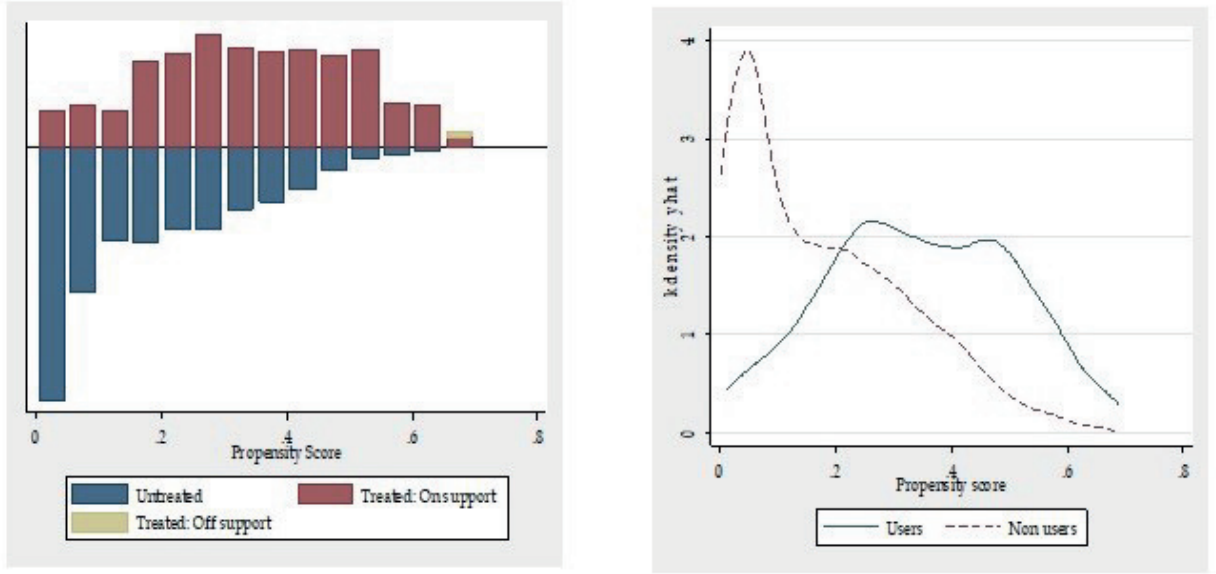

Figure C.1: Common support conditions

Table C.7: Matching quality test

\begin{tabular}{lccccc}
\hline \hline Sample & Pseudo $R^{2}$ & $L R \chi^{2}$ & $P>\chi^{2}$ & Mean standardized bias & Total bias reduction(\%) \\
\hline Before matching & 0.169 & 373.0 & 0.000 & 19.2 & $89.6 \%$ \\
After matching & 0.004 & 5.1 & 1.000 & 2.0 & \\
\hline \hline
\end{tabular}

Table C.8: Sensitivity analysis: Rosenbaum bounds (rbounds) and Mantel-Haenszel (MH) bounds

\begin{tabular}{|c|c|c|c|c|}
\hline \multirow[t]{2}{*}{ Outcomes } & \multicolumn{2}{|c|}{ rbounds } & \multicolumn{2}{|c|}{ mhbounds } \\
\hline & $\operatorname{sig}^{+}$ & $\operatorname{sig}^{-}$ & $p_{m h}^{+}$ & $p_{m h}^{-}$ \\
\hline Household dietary diversity score & 1.10 & $>3$ & & \\
\hline Minimum acceptable diet & & & $1.5-2.0,>3$ & $>3$ \\
\hline Per capita food consumption & 1.20 & $>3$ & & \\
\hline Per capita total consumption & 1.15 & $>3$ & & \\
\hline Child stunting & & & $1,>3$ & $1,>3$ \\
\hline
\end{tabular}

Note: Gamma: Odds of differential assignment due to unobserved factors $\operatorname{sig}^{+}$: upper bound significance level

sig $^{-}$: lower bound significance level

$p_{m h}^{+}$: Significance level (assumption: overestimation of treatment effect)

$p_{m h}^{-}$: Significance level (assumption: underestimation of treatment effect) 



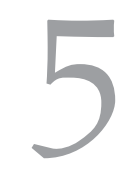

\section{SYNTHESIS}

\subsection{CONCLUDING REMARKS}

With the impacts of climate variability and extremes becoming sharper and population continuing to grow rapidly, the agricultural and food systems in SSA continue to struggle to feed the surging population, to improve nutrition and to contribute to poverty alleviation. A considerable number of people in the region still find themselves in rural areas and rely on agriculture for their livelihoods. Due to their vulnerability to weather and related shocks, they are plagued by a huge burden of food insecurity, malnutrition and persistent poverty. While there seems to be an interest to extol adoption of the Green revolution (RG) inputs as a solution to spur agricultural growth and poverty reduction, the distinct nature of the farming system in SSA and current challenges urge the need for a different innovation approach to agriculture. Climate-smart agricultural practices and technologies are being viewed as feasible options to surmount the constraints of conventional production systems and enhance food and nutrition security, promote sustainable diets and reduce the risk of sliding into poverty.

In this dissertation, we investigate the welfare and risk management impacts of three climate-smart land and crop management innovations: conservation agriculture, crop diversification and improved crop storage. Specifically, in this dissertation, we address three research objectives. First, we assess the poverty-reducing effect of conservation agriculture (CA) in rural Ethiopia. Second, we analyze the household welfare and risk coping effects of crop diversification in Uganda. Lastly, we investigate the impact of improved crop storage methods on food security and welfare in Ethiopia. In relation to the three objectives, we also investigate the drivers of households' decision to use these innovations.

This chapter summarises the main findings of the study and highlights the contribution of each chapter to different strands of the literature. It also discusses the policy implications of the study findings. Finally, it discusses the caveats of the study and suggests potential avenues for future research. 


\subsection{MAIN FINDINGS}

In chapter 2, we empirically analyze the impact of CA on poverty in rural Ethiopia. To elucidate the potential pathways through which CA affects rural poverty, we assess the impacts of CA on crop productivity, cost of production and downside risk. CA is among the globally promoted climate-smart practices. Evidence from agronomic and economic studies demonstrates that CA enhances soil health, increases and stabilises crop yields, reduces production costs and contributes to food security and climate resilience. We investigate the impact of CA on poverty, an area less explored in the literature. While there are few studies that explore the link between CA adoption and rural poverty, they rely on cross-sectional data, focus on a single CA practice do not disaggregate the impacts by CA practices. The chapter contributes to the emerging literature in many aspects. Firstly, we investigate the main factors that determine households' decision to use CA practices in isolation and in combination using georeferenced panel survey data that is representative of rural Ethiopia. With this, we try to address the empirical puzzle of low and unstable adoption of a combination of CA practices in SSA despite their theorized benefits. Secondly, we disaggregate the impacts of CA on poverty across different rainfall endowment and wealth groups. Third, we apply panel endogenous regression model in a polychotomous technology choice setting that helps us produce credible estimates after accounting for farmer heterogeneity.

The findings show that households use CA in response to climate anomalies and poor soil fertility. Important finding is that minimum tillage, cereal-legume intercropping and their combination are economically attractive in many circumstances. More important, the combined use of minimum tillage and cereal-legume intercropping is the most attractive CA option that reduces the incidence and extent of rural poverty. This CA package also increases crop income, reduces the cost of production and mitigates the risk of crop failure. Furthermore, these CA practices have higher poverty reducing benefits in areas that experience rainfall stress and among poor households positioned at lowest quartile of the landholding distribution. This provides evidence that CA has the potential to mitigate risk in environments characterised by increased weather risk. This insight also provides a way forward for increased promotion of minimum tillage, cereal-legume intercropping and their combination in those environments. However, crop residue retention and its combined use with minimum tillage do not appear to be attractive CA options for Ethiopian farmers. They rather tend to increase the likelihood of being poor particularly in areas with abundant rainfall and for relatively rich households. This suggests that the low adoption rate of these CA practices could explain a rational behaviour of farm households at least in the short run. We conclude with the assertion that CA promotion in Ethiopia needs not to be rigid. Overall, we make contributions to the CA literature with important policy implications for the design, targeting and promotion of CA. 
Pieces of evidence demonstrate that, in the aftermath of the Green Revolution (GR), there had been an increased promotion of farm specialization towards a few staple crops as a strategy to spur agricultural growth and enhance food security. Experiences from SSA and other developing countries show that reliance on mono-cropping practices has compounded the problems of soil fertility depletion, food and income insecurity and consumption risk. This is attributed to the decline in crop diversity that resulted from reliance on a few staple crops, which in turn exposes households to price shocks and climate change risks. There is now a resurgence of interest in diversification. This has also attracted many studies on the economics of crop diversification. While there are many seminal works that link crop diversity with risk, the relationship between crop diversity and household welfare is less studied. Likewise, there is paucity in the literature regarding the relationship between households' decision in the use of ex-ante risk management strategies and ex-post risk coping or consumption smoothing mechanisms. To contribute to the literature, in chapter 3 , we investigate the household welfare and risk coping effects of crop diversity in rural Uganda. Crop diversity is measured using various indices that help to capture the scope and extent of crop diversity. Household welfare is measured using consumption expenditure (a flow measure) and diet diversity (a stock measure). The empirical methodology applied is a panel data instrumental variables method that helps us to tackle unobserved heterogeneity and reverse causality.

The results show that climatic factors and market access significantly affect the degree of crop diversity maintained by households. The primary finding is that increasing crop diversity is associated with an increase in diet diversity. This suggests that diversified crop production could be a promising strategy to enhance food and nutrition security. Crop diversity has positive and significant effect on per adult equivalent consumption. Using a quantile regression, we find that crop diversity increases consumption for the poor segment of the rural sample with low consumption more than for the high consuming households. This finding helps to elucidate crop diversity as a potential path out of poverty for the rural poor. The study also shows that households that diversify crop production (self-insurance) are less likely to rely on the solidarity of their friends and relatives (informal insurance) to smooth their consumption ex-post shocks. However, the impact on risk coping through involuntary changes in diet is modest. The results suggest that crop diversity reduces rural households' use of less effective and adverse risk coping or consumption smoothing strategies. As a departure from existing claims that crop diversification would improve risk management at the cost of reduced welfare, our study demonstrates that crop diversity can help households balance the goals of risk management and welfare improvement. The chapter contributes to the development economics literature that links production and risk management decisions with household welfare and consumption smoothing in the context of market imperfections or missing markets. 
Crop or food storage decisions by rural households in developing countries are primarily driven by consumption smoothing and temporal price arbitrage motives. Seminal works in this field also demonstrate that the consumption smoothing motive is a stronger determinant of crop storage decisions. However, rural households often do not benefit from crop storage due to the high risk of storage losses. Postharvest losses, therefore, would significantly affect food and nutrition security and welfare of households who lack access to improved storage technologies. In chapter 4, we analyse the impact of improved crop storage technology use on household nutrition, food security, consumption expenditure and child growth in rural Ethiopia. Using endogenous switching regression methods, we find evidence that use of improved crop storage methods increases household diets, lessens self-reported food insecurity and reduces the risk of child stunting. We conclude that promoting increased use of food storage innovations plays a key role in increasing food and nutrition security.

In sum, the dissertation provides evidence that cereal-legume intercropping, minimum/reduced tillage, crop diversification and improved food storage methods are climate-smart agricultural innovations that could potentially improve household welfare. They could also improve the risk management capacity of farm households by reducing the risk of crop failure and decreasing reliance on less effective food insecurity and risk coping mechanisms. The findings suggest that adoption of these climatesmart innovations is crucial to adapt to climate change, alleviate rural poverty and reduce hunger. Likewise, improving infrastructure, extension, and access to credit are necessary to encourage adoption of these climate-smart practices and technologies. Taken together, the chapters in the dissertation made important contributions to the different but related strands of the literature on climate change adaptation, household welfare and risk management.

\section{$5 \cdot 3$ POLICY RECOMMENDATIONS}

The results from this dissertation unambiguously show that the three climate-smart innovations have the potential to increase food security, agricultural productivity and household well-being. This suggests that increased promotion of these agricultural innovations is inevitable. However, this process demands making such innovations accessible and work for the poor. Poor and food insecure farmers often find it hard to innovate and invest in better management systems because of many challenges they faced. First, they are often engaged in finding food for self-sufficiency. Second, resource-poor farmers often lack access to markets and capital that limit their ability to innovate and raise their income. Therefore, targeting climate-smart innovations for the poor needs to prioritize alleviating the various constraints they face and facilitate incentives to impulse them take-up remunerative innovations.

Minimum tillage, cereal-legume intercropping and their combination are found to be the CA practices that reduce the incidence and extent of rural poverty in Ethiopia. 
However, crop residue retention and its combined use with minimum tillage are found to be unattractive CA options. The findings suggest that agricultural research and extension organizations need to be cautious while promoting CA. Thus, increased promotion of CA practices with considerable economic benefits deserves a policy priority. This is particularly important given a significant farm heterogeneity in terms of resource endowments, exposure to weather and biophysical conditions. Nonetheless, many CA practices provide higher economic benefits to farmers only after considerable time. Resource poor households that are labour and credit constrained might find it difficult to invest in CA practices that require labour and incur substantial costs that must be borne before the benefits are reaped. Thus, such innovations could be less attractive to poor farmers who have higher discount rates and present bias. Therefore, wider scale adoption of CA demands improved access to financial resources, capacity building and knowledge and policy support.

Climate-smart innovations such as CA are also knowledge-intensive. Thus, creating knowledge platforms where farmers can learn about such innovations could be a priority for promoting the innovations. There are many options through which farmers can learn about climate-smart solutions for the problems they face. One is educating farmers about the real impacts of climate change and conventional farming. This will compel farming households to reduce their reliance on unsustainable farming practices and increase use of climate-smart practices to increase food production in the face of environmental risks. Formation of knowledge exchange forums such as agriculture innovation platforms is important to bring climate-smart technologies and practices to farmers' attention. This includes creating stages for farmers to learn from successful farmers, demonstrations, scientists, and experimentation. Government extension is the primary source of information for innovations in rural Africa. Hence, strengthening the extension system and other capacity development programs such as education, training and nutrition knowledge would help farmers reap higher welfare benefits from climate-smart innovations.

The positive and significant impacts of crop diversity on household welfare and risk management suggest that policies should be directed to encourage and increase crop diversity. Developing effective policies for household welfare improvement and risk management needs to give attention to promoting and extending services that encourage crop diversification. Likewise, appropriate governance, policies and national implementation are called for enhancing crop diversity conservation. The findings provide useful insights for policies that aim to help households mitigate food insecurity and adapt to climate change through diversification of crop production. Results from the drivers of crop diversification suggest that promoting crop diversification in areas with less access to markets and low rainfall would be effective to improve welfare and risk management in these areas. Furthermore, agricultural production diversity can complement health-related interventions that aim to tackle malnutrition 
and the risk of hidden hunger in SSA. This implies that aligning agricultural and health policies would help generate better benefits from agricultural diversification.

This study finds that improved crop storage technologies contribute to household diet diversity, reduce food insecurity and the risk of child stunting. However, these technologies are capital intensive and their use could be a challenge for poor and credit-constrained households. Improving farmers' access to credit and information sources could play a crucial role to facilitate investment in improved storage technologies. This demands development of rural financial markets including credit and savings markets. In addition to improving access to credit and information, improving farmers' skills as well as their access and awareness of improved food storage technologies would prove higher benefits.

\section{$5 \cdot 4$ STUDY LIMITATIONS}

The caveats of the study are important. The major limitation of this study is related to lack of relevant data to conduct in-depth analysis. Because the LSMS-ISA is a multitopic survey not planned to undertake a detailed analysis on a specific topic, there is no adequate data regarding prices of commodities and post-harvest loss information. Lack of relevant data limits investigation of the drivers and welfare impacts of improved food storage use in detail. Due to data limitations, the empirical link between CA and household poverty also lacks the required detail and scope. Another limitation of the study is related to the way CA use is defined. From sustainable intensification perspective, estimating the impact of CA adoption intensity on poverty would be interesting. However, the present study adopts a binary measure for the CA practices. The short panel data we have also compelled us not to do a detail analysis of the dynamics in climate-smart innovations use and the welfare metrics.

Despite these caveats and limitations, we provide important contributions to the current economics literature and contemporary policy discussions. The choice of the study countries is partly driven by data availability. Nevertheless, the findings and conclusions of this study could be generalizable to other countries with similar environments. This study is also limited in scope. Although it addresses only the boundary markers of several microeconomic challenges facing rural households in SSA, it should be emphasized that there is always more detail within this border.

\subsection{AREAS FOR FUTURE RESEARCH}

The research here can be extended in various ways. In chapter 2, we investigate the impact of CA on rural poverty and elucidate potential pathways. Assessing the impact of the intensity of CA is also interesting. Furthermore, exploring the drivers and impact of farmer's switching in and out of CA adoption would be interesting. Investigating 
the impact of CA on nutrition outcomes would also be interesting idea. The study can also be extended by investigating the effectiveness of other modern farm inputs such as chemical fertiliser under CA to test if CA improves fertiliser use and the resulting impact on farm productivity. We measure poverty using consumption metrics. However, it is crucial to look beyond such consumption metrics and consider indicators that could capture multidimensional poverty and subjective measure of well-being.

The link between crop diversity and household welfare can also be extended in several ways. Our finding reveals that crop diversity increases consumption expenditure and household diet diversity. However, a policy focus on the increased promotion of crop diversification would discourage the adoption of modern agricultural inputs such as fertiliser. Therefore, assessing the impact of crop diversification on agricultural input use and the resulting effect on farm productivity deserves further research. Furthermore, analyzing potential complementarity between agricultural production diversity and health-related interventions in relation to their impact on malnutrition and the risk of hidden hunger would be interesting from a policy viewpoint.

The study on the impacts of improved crop storage technologies can also be extended. Looking into the demand side determinants of improved storage technology adoption using demand valuation methods and experimental designs would help increase our understanding of the drivers of demand for improved crop storage. Another focus for further research would be a comprehensive investigation of the consumption smoothing and price arbitrage effects of improved storage technologies. Moreover, analysing the impact of improved crop storage technologies on shifts in resource allocation, climate change mitigation and market price stabilization would be of paramount importance for policymaking. 


\section{VALORISATION ADDENDUM}

In accordance with article 23.5 of the "Regulation governing the attainment of doctoral degrees at Maastricht University" decreed by resolution of the Board of Deans, dated 3 July 2013, this chapter on addendum discusses the valorization opportunities of this doctoral thesis.

The dissertation seeks to increase our understanding of the microeconomic challenges facing rural households in Sub-Saharan Africa (SSA). It comprises three essays that investigate the decisions agricultural households make in crop and land management, crop portfolio choices and postharvest storage to cope with economic and environmental risks and improve their welfare. Understanding the relationship between the choices of agricultural households in the production process and their welfare can help us better understand the economic growth constraints in the region. The study employs empirical strategies backed by theoretical foundations that help us identify causal relations. The findings have important contributions to the literature and provide relevant policy recommendations that could assist rural households on their path to development.

Rural households in SSA face food crisis of many dimensions including malnutrition, poverty, and food insecurity. They are also at the front lines of climate variability and extremes that exacerbate food insecurity and poverty. These households are also burdened by the challenges of low soil fertility and postharvest loss. In a disconcerting paradox, they are pushed out of the credit and insurance markets. As a result, they are unable to adapt to and cope with shocks. As a result of these interlinked challenges, promoting economic growth and poverty reduction in the region becomes a daunting task. What is most striking is that nearly three-quarters of the poor people still live in rural areas and work in agriculture. Due to the sheer number of people employed in agriculture and limited non-farm employment opportunities, agriculture continues to be the most important sector of focus in SSA.

Conventional wisdom holds that growth in agricultural productivity is central to alleviating poverty, reducing malnutrition and improving food security in developing countries. Despite this enthusiasm, climate change and rising demographic pressures in SSA are putting pressure on the capacity of agriculture to meet the growing demand for food and to raise rural incomes. The challenge to do so also lies in the fact that the natural resource base that supports agriculture is significantly constrained and degraded. As a panacea to the old input-intensive production systems, sustainable intensification and climate-smart agricultural practices are being promoted as 
a way forward for future productivity growth and to aid sustainable and inclusive development in SSA.

This dissertation investigates the impacts of three climate-smart innovations, conservation agriculture, crop diversity and improved crop storage on household welfare and risk management. The primacy of the policy contribution of the study is that the essays in the dissertation have a strong link with the discussion of the Sustainable Development Goals (SGDs), particularly goal 1, 2 and 13. The findings of the study provide evidence that climate action in agriculture (goal 13) through climatesmart innovations will help to reduce poverty and combat hunger (goals 1 and 2). The empirical strategies employed in the dissertation enable us to address common econometric challenges and produce credible estimates. Our study provides important insights for policy makers, agricultural policy advisors, as well as researchers in the field of agricultural and development economics.

As Schultz puts it during his lecture to the memory of Alfred Nobel in 1979, we could best know about the economics of being poor if we knew the economics of agriculture because most of the poor people are employed in agriculture. With this thrust, in chapter 2, we investigate the potential of conservation agriculture (CA), a climate smart and sustainable agricultural practice, to reduce the incidence and extent of poverty in rural Ethiopia. The findings from the study suggest that combined use of minimum tillage and cereal-legume intercropping is a promising technology to increase agricultural performance, mitigate risk of crop failure and reduce rural poverty. From policy perspectives, promoting minimum tillage and cereal-legume intercropping would mark a path forward for alleviating poverty in regions facing environmental risks. The study provides important evidence for policy initiatives that aim at reducing rural poverty which is at the forefront of the Sustainable Development Goals (SDGs).

In chapter 3, we assess the economic impacts of crop diversification on household welfare and risk coping in Uganda. While the discussion of the economics of specialization versus diversification has a long history in applied economics and related disciplines, the debate remains important in recent works. The findings from the study show that crop diversification improves household diets and increases consumption expenditure. An interesting finding is that crop diversification improves consumption for poor households compared to richer households. Furthermore, farmers' risk management decision in the form of crop diversification reduces the need for reliance on external help as a risk coping mechanism in the event of shocks. Our finding suggests that increased crop diversity would be more important to enhance food security and improve household welfare. Therefore, policies need to encourage crop diversity than farm-level specialization towards few staple crops to spur growth in agriculture.

Economic theory asserts that rural households in developing countries that face uncertainty and incomplete insurance markets use various mechanisms to smooth 
consumption and stabilize utility. Liquidity constrained households engage in selfaccumulation of assets in the form of crop or food storage as a measure of ex-post consumption smoothing. In chapter 4 , we investigate how improved crop storage methods affect food and nutrition security, consumption expenditure and child growth in Ethiopia. We find evidence that improved storage innovations generate benefits both at the household and individual (child) levels. The findings have policy implications for crop loss mitigation, enhancing food and nutrition security and climate change adaptation.

To recap, the findings of the study will support the development of climate smart policies that would emphasize incentives and capabilities to encourage improved decision-making at the farm household level. The evidence could be of interest to policy makers and other stakeholders at different levels. The research will be available to governments, researchers and policymakers through various means. Preliminary findings of chapter 2 were presented at Cornell University in July 2017 and at the Structural Transformation of African Agriculture and Rural Spaces (STAARS) workshop in Abidjan (Côte d'Ivoire) at the African Development Bank (AfDB) Headquarters in December 2017. Chapter 4 is already published in the Journal of Food Policy as "Tesfaye, W. \& Tirivayi, N. (2018). The impacts of postharvest storage innovations on food security and welfare in Ethiopia. Food Policy, 75(100), 52-67". The link between climate risks, climate-smart innovations and welfare in SSA is an active area of research. We also suggest future research avenues that could expand the present study. 
Wondimagegn Mesfin obtained his MSc in Agricultural Economics and a BSc in Agribusiness Management both from Haramaya University, Ethiopia. Upon successful completion of his undergraduate study, he won a position as a Graduate Assistant at Haramaya University. Before joining UNU-MERIT in September 2014 as a PhD fellow, he has served as a Lecturer at the same University. During his stay at UNU-MERIT, he has worked as an evaluator for three impact evaluation consultancies commissioned by CARE International in Zimbabwe and the World Food Programme (WFP) of the United Nations in Kenya and Malawi. He has also served as an MPP Masters Thesis advisor and a second reader. Wondimagegn has been a Structural Transformation of African Agriculture and Rural Spaces (STAARS) fellow in 2017 at Cornell University with a financial support from the CGIAR Research Program on Policies, Institutions, and Markets (PIM).

Wondimagegn's research interest is in Applied Economics with a primary focus on Development and Agricultural Economics. Specific research areas of interest include, but not limited to, welfare dynamics analysis, agricultural innovations and social networks, impacts of risk/shocks on households and individuals and management strategies, exchange innovations and information technologies, employment and labor market analysis, structural transformation, climate change-economy nexus, sustainable intensification and social protection. He has strong and solid interest in Microeconometrics (cross-sectional and panel data), impact evaluation, and mathematical programming. Wondimagegn is an Ethiopian. 


\section{UNU-MERIT/MGSoG Dissertation Series}

2019

\section{Wondimagegn Mesfin Tesfaye}

Essays on the Impacts of Climate-

Smart Agricultural Innovations on

Household Welfare

UNU-MERIT/MGSoG Dissertation

Series № 219

\section{Tatevik Poghosyan}

How Board Networks Affect Firm

Performance and Innovation Incentives

in Transition Economies: The Case of

Armenia

UNU-MERIT/MGSoG Dissertation

Series № 218

\section{Arip Muttaqien}

Essays on Inequality and Polirization:

Empirical Studies in Developing Asia

UNU-MERIT/MGSoG Dissertation

Series № 217

2018

\section{Katrin Marchand}

Essays on Forced Migration and

Labour Market Participation in

Developing Countries

UNU-MERIT/MGSoG Dissertation

Series № 216

\section{Ortrun Merkle}

The Myth of Gender Neutral Power:

Corruption and Gender Norms

UNU-MERIT/MGSoG Dissertation

Series № 215

\section{Biljana Meshkovska}

Life after Trafficking:

(re)integration processes of women that have been trafficked for the purpose of sexual exploitation in Europe

UNU-MERIT/MGSoG Dissertation

Series № 214

\section{Vincenzo Vinci}

The Relevance of Institutions and

People's Preferences for Social

Protection

UNU-MERIT/MGSoG Dissertation

Series № 213

\section{Silke Heuser}

The Effectiveness of Environmental Policies on Reducing Deforestation in the Brazilian Amazon

UNU-MERIT/MGSoG Dissertation

Series № 212

\section{Jennifer Waidler}

Social Assistance and Remittances and Their Role in the Fight Against

Poverty

UNU-MERIT/MGSoG Dissertation

Series № 211 


\section{Choolwe Muzyamba}

The role of community mobilization in the promotion of maternal health of women living with HIV in Zambia UNU-MERIT/MGSoG Dissertation Series № 210

\section{Juan Carlos A. Castillo Sánchez}

Assessing the Role of the Export Sector in Mexican Economic

Development,1965-2014

UNU-MERIT/MGSoG Dissertation Series № 209

\section{Tareq Abuelhaj}

Food Security Policy Impact Analysis:

The Econometrics of Cash and Food

Assistance Cost Effectiveness

UNU-MERIT/MGSoG Dissertation

Series № 208

Marta Férnandez de Arroyabe Arranz

Essays on MEAS and Innovation UNU-MERIT/MGSoG Dissertation Series № 207

\section{Clotilde Mahé}

Essays on Migration and Occupational Choice

UNU-MERIT/MGSoG Dissertation Series № 206

\section{Simone Sasso}

Talent on the move. Essays on Human Capital, Graduate Mobility and Economic Development UNU-MERIT/MGSoG Dissertation Series № 205
Khaled Walid Rajab

Strategic Planning under Fragility UNU-MERIT/MGSoG Dissertation Series № 204

\section{Mutinta Hambayi Nseluke}

A Tall Order: Improving Child Linear Growth

UNU-MERIT/MGSoG Dissertation Series № 203

\section{Elvis Korku Avenyo}

Innovations and Firm Performance in sub-Saharan Africa: Empirical Analyses

UNU-MERIT/MGSoG Dissertation Series № 202

\section{Ni Zhen}

Employment Dynamics, Firm

Performance and Innovation

Persistence in the Context of Differentiated Innovation Types:

Evidence from Luxembourg UNU-MERIT/MGSoG Dissertation Series № 201

\section{Caroline Wehner}

Too Scared to Achieve: The Relation

Between Neuroticism,

Conscientiousness

and Socioeconomic Outcomes

UNU-MERIT/MGSoG Dissertation

Series № 200

\section{Stefania Innocenti}

On Institutional Persistence

UNU-MERIT/MGSoG Dissertation Series № 199 


\section{Hassen Abda Wako}

Economic Globalization, Institutions and Development: Essays on Aid, Foreign Direct Investment and Trade UNU-MERIT/MGSoG Dissertation Series № 198

2017

\section{Hans-Erik Edsand}

Winds of Change

UNU-MERIT/MGSoG Dissertation Series № 197

\section{Ana Patricia Silva Vara}

Redressing the Gender Gap

UNU-MERIT/MGSoG Dissertation

Series № 196

\section{Andrés Iván Mideros Mora}

Essays on the Economic Effects of Noncontributory Social Protection UNU-MERIT/MGSoG Dissertation Series № 195

\section{Tobias Broich}

New Actors in the Global Economy UNU-MERIT/MGSoG Dissertation Series № 194

\section{Bernard Nikaj}

From No-government to E-government UNU-MERIT/MGSoG Dissertation Series № 193

\section{Ali Safarnejad}

Prioritizing the HIV Response UNU-MERIT/MGSoG Dissertation Series № 192

\section{Clovis Freire}

Diversification and Structural

Economic Dynamics

UNU-MERIT/MGSoG Dissertation

Series № 191

\section{Michael Verba}

Innovation and Knowledge Dynamics:

Essays on the Knowledge Economy

UNU-MERIT/MGSoG Dissertation

Series № 190

\section{Pui Hang Wong}

The Hearts and Minds in Conflict and Peace: The Economics of

Counterinsurgency and the Psychology of Reconstruction

UNU-MERIT/MGSoG Dissertation

Series № 189

\section{Brenda Yamba}

Schooling Despite All Odds: Evidence from Lesotho on Female Child Carers who Stayed in School UNU-MERIT/MGSoG Dissertation Series № 188

\section{Sheng Zhong}

Moving towards An Energy Efficient Future: Essays on Energy Efficiency, Technology and Development UNU-MERIT/MGSoG Dissertation Series № 187 


\section{Julieta Marotta}

Access to Justice and Legal

Empowerment of Victims of Domestic

Violence through Legal Organizations in the City of Buenos Aires: A

Qualitative Empirical Legal Study

UNU-MERIT/MGSoG Dissertation

Series, № 186

\section{Andrea Franco-Correa}

On the Measurement of

Multidimensional Poverty as a Policy

Tool: Empirical Applications to Chile,

Colombia, Ecuador and Peru

UNU-MERIT/MGSoG Dissertation

Series, № 185

2016

Yesuf Awel

Insurance for Growth: Empirical

Essays on Insurance Demand and

Impacts in Africa

UNU-MERIT Dissertation Series,

№ 108

\section{Tigist Mekonnen Melesse}

Grow More Food using Fewer

Resources: Agricultural Technology

Adoption and Innovation Practices for

Inclusive and Sustainable

Development

UNU-MERIT Dissertation Series, № 107

\section{Eleni Yitbarek}

Getting Ahead or left Behind? Essays

on Poverty Dynamics and Social

Mobility in Africa

UNU-MERIT Dissertation Series,

№ 106

\section{Thuy Dieu Nguyen}

Firm-Level Theory and Evidence of

Corruption

UNU-MERIT Dissertation Series,

№ 105

\section{Raquel Tsukada Lehman}

Essays on Household Production with

Labor-Saving Technology

UNU-MERIT Dissertation Series,

№ 104

\section{Eva Barteková}

Multi-Problem Challenges for a

Renewable Future: Empirical Studies

on Competitive Disadvantages from

Electricity Price Differentials and

Mineral Supply Risk in an Open

Economy

UNU-MERIT Dissertation Series,

№ 103

\section{Jocelyn Olivari}

Entrepreneurial Traits and Innovation:

Evidence from Chile

UNU-MERIT Dissertation Series,

№ 102

\section{Muhammad Shafique}

Essays on the role of knowledge, RED, and Technology-based Firms in the Evolution of Socio-techno-economic System

UNU-MERIT Dissertation Series, № 101 


\section{Serdar Türkeli}

Governance of Innovation Policy:

Empirical Studies on Applied Political

Economy by Multi-Methods Analysis

UNU-MERIT Dissertation Series,

№ 100

\section{Ayokunu Adedokun}

Pathways to Sustainable Peace

building in Divided Societies: Lessons

and Experiences from Mozambique

MGSoG Dissertation Series, № 75

\section{Luiz Rothier Bautzer}

Organizing Concurrent Engineering

through ICT Platforms

Blueprinting Product Lifecycle

Management Platforms across

Disciplinary Agencies

MGSoG Dissertation Series, № 74

\section{Natalia Popova}

Migration in the Periphery of the

European Union:

Determinants of Successful and

Sustainable Labour Market Integration of Return Migrants in Albania, Egypt, Moldova and Tunisia

MGSoG Dissertations Series, № 73

\section{Richard A. Martina}

Uncertainty and Resource Constraint in the Small Island Developing States: Essays in Entrepreneurial Cognition MGSoG Dissertations Series, № 72

\section{Cécile Cherrier}

The Expansion of Basic Social

Protection in Low-income Countries:

An Analysis of Foreign Aid Actors'

Role in the Emergence of Social

Transfers in Sub-Saharan Africa

MGSoG Dissertations series, № 71

\section{Paul Caldron}

The Tacit Bargain in Short-Term

Medical Missions: Why U.S.

physicians go and what it costs

MGSoG Dissertation Series, № 70

\section{Mahmut Kobal}

Customs \& Excellence: A Comparative Approach on Administrative and Regulatory Compliance Perspectives of the EU-Turkey Customs Union

MGSoG Dissertation Series, № 69

\section{Craig Loschmann}

Essays on Conflict-related Migration

and Development in the Case of

Afghanistan

MGSoG Dissertations Series, № 68

\section{Andrea Milan}

Rural Livelihoods, Location and

Vulnerable Environments: Approaches

to Migration in Mountain areas of

Latin America

MGSoG Dissertation Series, № 67

\section{Farida Lada}

On Guarding the Welfare of Clinical

Trial Subjects While Promoting Novel

Drug Innovation

A Game Theoretical Approach

MGSoG Dissertation Series, № 66 
Hibret Belete Maemir

Dissecting Aggregate Productivity:

International Integration and Growth

with Heterogeneous Firms

UNU-MERIT Dissertation Series,

№ 96

\section{Giorgio Triulzi}

Looking for the Right Path: Technology

Dynamics, Inventive Strategies and

Catching-up in the Semiconductor

Industry

UNU-MERIT Dissertation Series, № 95

\section{Abdul Baseer Qazi}

Knowledge flows and networks in the ICT sector: The case of Pakistan

UNU-MERIT Dissertation Series, № 94

\section{Ajay Thutupalli}

Technology Paradigm Shifts in

Agriculture: Drivers of Sustainability

and Catch up

UNU-MERIT Dissertation Series, № 93

\section{Eduardo Urias}

Improving access to HIV/AIDS

treatment in Brazil: When are

Compulsory Licenses effective in Price

Negotiations?

UNU-MERIT Dissertation Series, № 92
Why have so few Countries

Industrialised?

UNU-MERIT Dissertation Series, № 91

\section{Daniel Opolot}

The Evolution of Beliefs and Strategic

Behaviour

UNU-MERIT Dissertation Series,

№ 90

\author{
Alejandro Lavopa \\ Structural Transformation and \\ Economic Development: Can \\ Development Traps be Avoided \\ UNU-MERIT Dissertation Series, \\ № 89
}

\section{Jinjin Zhao}

Urban water management reform: The Case of China

UNU-MERIT Dissertation Series, № 88

\section{Simona Vezzoli}

Borders, Independence and Postcolonial Ties: the Role of the State in Caribbean Migration

MGSoG Dissertation Series, № 65

\section{Silvia Consuelo Gómez Soler}

Civil Conflict and Education: How

Does Exposure to Civil Conflict Affect

Human Capital Accumulation?

Evidence from Standardized Exit

Exams in Colombia

MGSoG Dissertation Series, № 64 


\section{Paula Nagler}

Occupational Choice in the Developing

World

MGSoG Dissertation Series, № 63

\section{Jasmin Kientzel}

Determinants of Professional

Commitment to Environmental

Sustainability

MGSoG Dissertation Series, № 62

\section{Mehmet Güney Celbiş}

Regional Policies: Convergence, Trade, and the Allocation of Public Capital

MGSoG Dissertation Series, № 61

\section{Florian Henning}

Living Up to Standard:

Interoperability Governance and

Standards Adoption in Government

Information Networks

MGSoG Dissertation Series, № 60

\section{Niels P. Groen}

The Never-Ending Project

Understanding E-Government Project

Escalation

MGSoG Dissertation Series, № 59

\section{Derek Copp}

Teacher-Based Reactivity to Provincial Large-scale Assessment in Canada MGSoG Dissertation Series, № 58

\section{Michaella Vanore}

Family-Member Migration and the Psychosocial Health Outcomes of Children in Moldova and Georgia MGSoG Dissertation Series, № 57

\section{Sonja Fransen}

The Economic and Social Effects of Remittances and Return Migration in Conflict-Affected Areas: The Case of Burundi

MGSoG Dissertation Series, № 56

\section{Ibrahim Khalil Conteh}

The Impact of Floods on Primary

School Education in Zambia

MGSoG Dissertation Series, № 55

\section{Richard Bluhm}

Growth Dynamics and Development Essays in Applied Econometrics and Political Economy

MGSoG Dissertation Series, № 54

\section{Nevena P. Zhelyazkova}

Work-Family Reconciliation and Use of Parental Leave in Luxembourg:

Empirical Analysis of Administrative Records

MGSoG Dissertation Series, № 53

\section{4}

\section{Dirk Crass}

The Impact of Brands on Innovation and Firm Performance: Empirical Evidence from Germany

UNU-MERIT Dissertation Series, № 87

\section{Samyukta Bhupatiraju}

The Geographic Dimensions of Growth and Development

UNU-MERIT Dissertation Series, № 86 


\section{François Lafond}

TheEvolution of Knowledge Systems

UNU-MERIT Dissertation Series, № 85

\section{Annalisa Primi}

Promoting Innovation in Latin

America: What Countries Have

Learned (and What They Have Not) in

Designing and Implementing

Innovation and Intellectual Property

Policies

UNU-MERIT Dissertation Series, № 84

\section{Fatoumata Lamarana Diallo}

Evaluation of Meal and Deworming Programs for Primary Schools in Rural Senegal

UNU-MERIT Dissertation Series, № 83

\section{Sachin Kumar Badkas}

Metachoice and Metadata: Innovating with Environmental Policy Analysis in Europe

MGSoG Dissertation Series, № 52

\section{Irina S. Burlacu}

An Evaluation of Tax-Benefit Systems Impact on the Welfare of Frontier Worker:

The Case of Luxembourg and Belgium MGSoG Dissertation Series, № 51

\section{Özge Bilgili}

Simultaneity in Transnational

Migration Research: Links Between

Migrants' Host and Home Country

Orientation

MGSoG Dissertation Series, № 50

\section{Yulia Privalova Krieger}

Reshaping the Big Agenda:

Transnational Politics and Domestic ResistanceFinancial crisis and social protection reform in Bosnia and

Herzegovina

MGSoG Dissertation Series, № 49

\section{Marieke van Houte}

Moving Back or Moving Forward?

Return migration after Conflict

MGSoG Dissertation Series, № 48

\section{Oxana Slobozhan}

Global Governance in the Management of Natural Resources: The Case of the Extractive Industries Transparency Initiative (EITI)

MGSoG Dissertation Series, № 47

\section{Luis Bernardo Mejia Guinand}

The Changing Role of the Central

Planning Offices in Latin America: A

Comparative Historical Analysis

Perspective (1950-2013)

MGSoG Dissertation Series, № 46

\section{Cheng Boon Ong}

Ethnic Segregation in Housing,

Schools and Neighbourhoods in the

Netherlands

MGSoG Dissertation Series, № 45

\section{Luciana V. Cingolani}

Bureaucracies for Development:

Oxymoron or Reality? Studies on State

Capacity in Challenging Governance

Contexts

MGSoG Dissertation Series, № 44 


\section{Carlos Cadena Gaitán}

Green Politics in Latin American

Cities - Sustainable Transport Agendas

MGSoG Dissertation Series, № 43

\section{Katie Kuschminder}

Female Return Migration and

Reintegration Strategies in Ethiopia

MGSoG Dissertation Series, № 42

\section{Metka Hercog}

Highly-Skilled Migration and New

Destination Countries

MGSoG Dissertation Series, № 41

\section{Margaret Agaba Rugadya}

Can Remittances Influence the Tenure and Quality of Housing in Uganda?

MGSoG Dissertation Series, № 40

\section{Ilire Agimi}

New Governance Under Limited

Statehood: The Case of Local

Government Reform in Kosovo

MGSoG Dissertation Series, № 39

2013

\section{Anant Kamath}

Information Sharing through Informal

Interaction in Low-Tech Clusters

UNU-MERIT Dissertation Series, № 82

\section{Flavia Pereira de Carvalho}

What we talk about when we talk about Brazilian Multinationals: An Investigation on Brazilian FDI, Economic Structure, Innovation and the Relationship between them UNU-MERIT Dissertation Series, № 81

\section{Jun Hou}

Complementarity in Innovation and Development: A Cross-country

Comparison

UNU-MERIT Dissertation Series, № 80

\section{Rufin Baghana}

Impacts of Government Incentives to RED, Innovation and Productivity: A Microeconometric Analysis of the Québec Case

UNU-MERIT Dissertation Series, № 79

\section{Lilia I. Stubrin}

High-Tech Activities in Emerging Countries: A Network perspective on the Argentinean Biotech Activity UNU-MERIT/MGSoG Dissertation Series, № 78

\section{Kristine Farla}

Empirical Studies on Institutions, Policies and Economic Development MGSoG Dissertation Series, № 38 
Marina Petrovic

Social Assistance and Activation in the Pursuit of Happiness: Shedding New

Light on Old Policy Solutions to Social Exclusion

MGSoG Dissertation Series, № 37

\section{Laura Torvinen}

Assessing Governance Assessments:

The Case of Mozambique: Governance

Assessments in the Context of Aid

Effectiveness Discourse

MGSoG Dissertation Series, № 36

\section{Biniam Egu Bedasso}

Institutional Change in the Long

Shadow of Elite: Essays on

Institutions, Human Capital and

Ethnicity in Developing Countries

MGSoG Dissertation Series, № 35

\section{Sepideh Yousefzadeh Faal}

Deghati

Childhoods Embargoed: Constructing

and Reconstructing Multidimensional

Child Poverty in Iran 1984-2009

MGSoG Dissertation Series, № 34

\section{Robert Bauchmüller}

Investing in Early Childhood Care and Education: The Impact of Quality on Inequality

MGSoG Dissertation Series, № 33

\section{Martin Rehm}

Unified Yet Separated: Empirical

Study on the Impact of Hierarchical

Positions within Communities of

Learning

MGSoG Dissertation Series, № 32
2012

\author{
Abdul Waheed \\ Innovation Determinants and \\ Innovation as a Determinant: Evidence \\ from Developing Countries \\ UNU-MERIT Dissertation Series, \\ № 77
}

\section{Bilal Mirza}

Energy Poverty and Rural Energy

Markets in Pakistan

UNU-MERIT Dissertation Series, № 76

\section{Benjamin Engelstätter}

Enterprise Software and Video Games:

An Empirical Analysis

UNU-MERIT Dissertation Series,

№ 75

\section{Fulvia Farinelli}

Natural Resources, Innovation and Export Growth: The Wine Industry in Chili and Argentina

UNU-MERIT Dissertation Series

\section{Rodolfo Lauterbach}

Innovation in Manufacturing: From

Product Variety and Labor

Productivity Growth to Economic

Development in Chile

UNU-MERIT Dissertation Series

\section{Kirsten Wiebe}

Quantitative Assessment of

Sustainable Development and Growth in Sub-Saharan Africa

UNU-MERIT Dissertation Series,

№ 74 


\section{Julio Miguel Rosa}

Organizational Strategies, Firms'

Performance and Spatial Spillovers:

The Canadian Case in Research and

Development.

UNU-MERIT Dissertation Series, № 73

Johannes Wilhelmus Marie Boels Joseph Schumpeter, Honderd Jaar

Economische Ontwikkeling: Een

Historisch-theoretische Beschouwing.

UNU-MERIT Dissertation Series

\section{Dorcas Mbuvi}

Utility Reforms and Performance of the

Urban Water Sector in Africa

MGSoG Dissertation Series, № 31

\section{Lina Salanauskaite}

Distributional Impacts of Public

Policies: Essays in Ex-Ante and Ex-

Post Evaluation

MGSoG Dissertation Series, № 30

\section{Esther Schüring}

To Condition or not - is that the

Question?

An Analysis of the Effectiveness of ExAnte and Ex-Post Conditionality in

Social Cash Transfer Programs

MGSoG Dissertation Series, № 29

\section{Joe Abah}

Strong Organisations in Weak States:

Atypical Public Sector Performance in

Dysfunctional Environments

MGSoG Dissertation Series, № 28

\section{Zina Samih Nimeh}

Social Citizenship Rights: Inequality

and Exclusion

MGSoG Dissertation Series, № 27

2011

\section{Daniel Vertesy}

Interrupted Innovation: Emerging

Economies in the Structure of the

Global Aerospace Industry

UNU-MERIT Dissertation Series,

№ 72

\section{Tina Saebi}

Successfully Managing Alliance

Portfolios: AnAlliance Capability View

UNU-MERIT Dissertation Series,

№ 71

\section{Nora Engel}

Tuberculosis in India: A Case of

Innovation and Control

UNU-MERIT/MGSoG Dissertation

Series, № 70

\section{Evans Mupela}

Connectivity and growth in Sub-

Saharan Africa: The Role of

Communication Satellites

UNU-MERIT Dissertation Series, № 69

\section{Nantawan Kwanjai}

Cross Cultural Intelligence amid

Intricate Cultural Webs: A Tale of the

UnDutchables in the Land of 1002

Smiles

UNU-MERIT Dissertation Series,

№ 68 


\section{Lina Sonne}

Innovation in Finance to Finance Innovation: Supporting Pro-poor Entrepreneur-based Innovation UNU-MERIT Dissertation Series, № 67

\section{Lenka Eisenhamerová}

Legitimacy of 'Humanitarian Military

Intervention'

MGSoG Dissertation Series, № 26

\section{Sonila Tomini}

Informal Payments for Health Care

Services in Albania

MGSoG Dissertation Series, № 25

\section{Jinjing Li}

Dynamic Microsimulation in Public

Policy Evaluation

MGSoG Dissertation Series, № 24

\section{Aziz Atamanov}

Rural Nonfarm Employment and International Migration as Alternatives to Agricultural Employment: The Case of Kyrgyzstan MGSoG Dissertation Series, № 23

\section{Frieda Vandeninden}

Poverty Alleviation: Aid and Social

Pensions

MGSoG Dissertation Series, № 22

\section{Juliana Nyasha Tirivayi}

The Welfare Effects of Integrating AIDS Treatment with Food Transfers:

Evidence from Zambia

MGSoG Dissertation Series, № 21

\section{Agnieska Ewa Sowa}

Who's Left Behind? Social Dimensions of Health Transition and Utilization of Medical Care in Poland MGSoG Dissertation Series, № 20

\section{Emmanaouil Sfakianakis}

The Role of Private Actors in the

Provision of Public Goods with

Applications to Infrastructure and

Financial Stability

MGSoG Dissertation Series, № 19

\section{Siu Hing Lo}

White Collars Green Sleeves: An Interorganizational Comparison of Determinants of Energy-Related Behaviors among Office Workers MGSoG Dissertation Series, № 18

\section{Treena $\mathbf{W u}$}

Constraints to Human Capital Investment in Developing Countries: Using the Asian Financial Crisis in Indonesia as a Natural Experiment MGSoG Dissertation Series, № 17

\section{Henry Espinoza Peña}

Impact Evaluation of a Job-Training Programme for Disadvantaged Youths: The Case of Projoven MGSoG Dissertation Series, № 16 
Fernando Santiago

Human Resources Management

Practices and Learning for Innovation

in Developing Countries:

Pharmaceutical Firms in Mexico

UNU-MERIT Dissertation Series, № 66

\section{Zakaria Babutsidze}

Essays on Economies with

Heterogeneous Interacting Consumers

UNU-MERIT Dissertation Series, № 65

\section{Bertha Vallejo}

Learning and Innovation Under

Changing Market Conditions: The

Auto Parts Industry in Mexico

UNU-MERIT Dissertation Series,

№ 64

\section{Donatus Ayitey}

Technical Change, Competitiveness and Poverty Reduction: A Study of the Ghanaian Apparel Industry

UNU-MERIT Dissertation Series, № 63

\section{Sergey Filippov}

Multinational Subsidiary Evolution:

Corporate Change in New EU Member States

UNU-MERIT Dissertation Series, № 62

\section{Asel Doranova}

Technology Transfer and Learning under the Kyoto Regime: Exploring the Technological Impact of CDM Projects in Developing Countries

UNU-MERIT Dissertation Series, № 61

\section{Florian Tomini}

Between Family and Friend:

Understanding the Interdependency of Private Transfers

MGSoG Dissertation Series, № 15

\section{Michał Polalowski}

The Institutional Transformation of

Social Policy in East Central Europe:

Poland and Hungary in Comparative and Historical Perspective

MGSoG Dissertation Series, № 14

\section{Maha Ahmed}

Defining, Measuring and Addressing

Vulnerability: The Case of Post

Conflict Environments

MGSoG Dissertation Series, № 13

\section{Pascal Beckers}

Local Space and Economic Success:

The Role of Spatial Segregation of

Migrants in the Netherlands

MGSoG Dissertation Series, № 12

\section{Victor Cebotari}

Conflicting Demands in Ethnically

Diverse Societies: Ethno political

Contention and Identity Values in

Europe

MGSoG Dissertation Series, № 11 
Dennis Gyllensporre

Competing and Complementary

Perspectives on the EU as a Crisis

Management Actor:

An Examination of the Common

Security and Defence Policy through

the Lenses of Idealism and Realism

MGSoG Dissertation Series, № 10

\section{Judit Vall Castello}

Business Cycle and Policy Effects on

Labour Market Transitions of Older

and Disabled Workers in Spain

MGSoG Dissertation Series, № 9

\section{Keetie Roelen}

False Positives or Hidden Dimensions:

The Definition and Measurement of

Child Poverty

MGSoG Dissertation Series, № 8

\section{Denisa Maria Sologon}

Earning Dynamics in Europe

MGSoG Dissertation Series, № 7

\section{Melissa Siegel}

Money and Mobility: Migration and

Remittances

MGSoG Dissertation Series, № 6

Jessica S. Hagen-Zanker

Modest Expectations: Causes and

Effects of Migration on Migrant

Households inSource Countries

MGSoG Dissertation Series, № 5
2009
Alexis Habiyaremye
From Primary Commodity Dependence
to Diversification and Growth:
Absorptive Capacity and Technological
Catch Up in Botswana and Mauritius.
UNU-MERIT Dissertation Series,
№ 60

\section{Yoseph Getachew}

The Role of Public Capital in Economic

Development

UNU-MERIT Dissertation Series, № 59

\section{Sandra Leitner}

Embodied Technological Change and

Patterns of Investment in Austrian

Manufacturing

UNU-MERIT Dissertation Series, № 58

\section{Semih Akçomak}

The Impact of Social Capital on

Economic and Social Outcomes

UNU-MERIT Dissertation Series, № 57

\section{Abraham Garcia}

The Role of Demand in Technical

Change

UNU-MERIT Dissertation Series, № 56

\section{Saurabh Arora}

Coherence in Socio-technical Systems:

A Network Perspective on the Innovation Process

UNU-MERIT Dissertation Series, № 55 


\section{Mirtha R. Muniz Castillo}

Human Development and Autonomy in Project Aid: Experiences from four bilateral projects in Nicaragua and $\mathrm{El}$ Salvador

MGSoG Dissertation Series, № 4

\section{Christiane Arndt}

Governance Indicators

MGSoG Dissertation Series, № 3

\section{Britta Augsburg}

Microfinance: Greater Good or Lesser

Evil?

MGSoG Dissertation Series, № 2

2008

\section{Rutger Daems}

Medicines for the Developing World UNU-MERIT Dissertation Series, № 54

\section{Johannes Hanel}

Assessing Induced Technology:

Sombart's Understanding of Technical

Change in the History of Economics

UNU-MERIT Dissertation Series,

№ 53

\section{Rifka Weehuizen}

Mental Capital: the Economic Significance of Mental Health UNU-MERIT Dissertation Series, № 52

\section{Danielle Cloodt}

The Relationship between RED

Partnership Formation, Social

Embeddedness and Innovative

Performance

UNU-MERIT Dissertation Series, № 51

\section{Sabine Fuss}

Sustainable Energy Development under Uncertainty

UNU-MERIT Dissertation Series,

№ 50

\section{Geranda Notten}

Measuring and Managing Poverty

Risks

MGSoG Dissertation Series, № 1

2007

\section{Tobias Kronenberg}

Reconciling Environmental

Conservation with Economic

Prosperity: The Feasibility of Double

Dividends in the Short and Long Run UNU-MERIT Dissertation Series, № 49

\section{Viktoria Kravtsova}

Assessing the Impact of Foreign Direct Investment in Transition Economies UNU-MERIT Dissertation Series, № 48 


\section{Suhail Sultan}

The Competitive Advantage of Small and Medium Sized Enterprises: The Case of Jordan's Natural Stone Industry

UNU-MERIT Dissertation Series, № 47

2006

\section{Bulat Sanditov}

Essays on Social Learning and Imitation

UNU-MERIT Dissertation Series, № 46

\section{Mamata Parhi}

Dynamics of New Technology

Diffusion: A Study of the Indian

Automotive Industry

UNU-MERIT Dissertation Series, № 45

\section{Andreas Reinstaller}

Social Structures and the Innovation Process: Their Role in the Demand of Firms and Consumers

UNU-MERIT Dissertation Series, № 44

\section{Rose Kiggundu}

Innovation systems and Development:

The Journey of a Beleaguered Nile

Perch Fishery in Uganda

UNU-MERIT Dissertation Series, № 43

\section{Thomas Pogue}

The Evolution of Research

Collaboration in South African Gold Mining: 1886-1933

UNU-MERIT Dissertation Series, № 42

\section{Geoffrey Gachino}

Foreign Direct Investment, Spillovers and Innovation: The Case of Kenyan Manufacturing Industry

UNU-MERIT Dissertation Series, № 41

\section{Önder Nomaler}

Technological Change, International Trade and Growth: An Evolutionary, Multi-Agents-Based Modeling

Approach

UNU-MERIT Dissertation Series, № 40

2005

\section{Samia Satti Osman Mohamed-}

Nour

Change and Skill Development in the Arab Gulf Countries

UNU-MERIT Dissertation Series, № 39

\section{Elad Harison}

Intellectual Property Rights:

Economics and Policy Analysis

UNU-MERIT Dissertation Series, № 38 


\section{Daniel Dalohoun}

Learning to innovate: agricultural innovation and entrepreneurship: the case of Songhai farmers in Benin UNU-MERIT Dissertation Series, № 37

\section{Müge Ozman}

Networks, Organizations and

Knowledge

UNU-MERIT Dissertation Series, № 36

\section{Bas Straathof}

Product Variety and Economic

Growth: The Counteracting Effects of Scale and Idiosyncrasy

UNU-MERIT Dissertation Series, № 35

\section{Wilfred Schoenmakers}

Knowledge Flows between

Multinational Companies: A Patent

Data Analysis

UNU-MERIT Dissertation Series, № 34

\section{Myriam Cloodt}

Mergers and Acquisitions ( $M$ and As) in High-Tech Industries: Measuring the Post-M and A Innovative

Performance of Companies

UNU-MERIT Dissertation Series, № 33
2004

\section{Paola Criscuolo}

$R \mathcal{E D}$ Internationalisation and

Knowledge Transfer: Impact on MNEs and their Home Countries

UNU-MERIT Dissertation Series, № 32

\section{Maarten Verkerk}

Trust and Power on the Shop Floor UNU-MERIT Dissertation Series, № 31

\section{Gottfried Leibbrandt}

Adoption, Harmonization and Succession of Network Technologies across Countries

UNU-MERIT Dissertation Series, № 30

\section{Mark Sanders}

Skill Biased Technical change: Its Origins, the Interaction with the Labour Market and Policy Implications UNU-MERIT Dissertation Series, № 29

2003

\section{Nadine Roijakkers}

Inter-firm Cooperation in High-tech Industries: a Study of RED

Partnerships in Pharmaceutical

Biotechnology

UNU-MERIT Dissertation Series, № 28 
Viki Sonntag

Speed, Scale and Sustainability

UNU-MERIT Dissertation Series, № 27

\section{Masaru Yarime}

From End-of-Pipe Technology to Clean Technology

UNU-MERIT Dissertation Series, № 26

\section{Stéphane Malo}

The Combinatorial Chemistry Revolution: Sustaining a Superior

Performance Position through

Technological Learning

UNU-MERIT Dissertation Series,

№ 25

2002

\section{Annelies Hogenbirk}

Determinants of Inward Foreign

Direct Investment: the Case of the

Netherlands

UNU-MERIT Dissertation Series, № 24

\section{Bastiaan Johan terWeel}

The Computerization of the Labour Market

UNU-MERIT Dissertation Series
2001

\section{John Adeoti}

Technology Investment in Pollution Control in Sub-Saharan Africa: The Case of the Nigerian Manufacturing Industry

UNU-MERIT Dissertation Series, № 23

\section{Edward Huizenga}

Innovation Management: How

Frontrunners Stay Ahead: An

Empirical Study on Key Success

Factors in the ICT sector

UNU-MERIT Dissertation Series, № 22

2000

\section{Machiel van Dijk}

Technological Change and the

Dynamics of Industries: Theoretical Issues and Empirical evidence from Dutch Manufacturing UNU-MERIT Dissertation Series, № 21

\section{9}

\section{Jan Cobbenhagen}

Managing Innovation at the Company Level: A Study on Non-Sector-Specific Success Factors UNU-MERIT Dissertation Series, № 20 


\section{Marjolein Caniëls}

Regional Growth Differentials: The

Impact of Locally Bounded Knowledge

Spillovers

UNU-MERIT Dissertation Series, № 19

1998

\section{Aldo Geuna}

Resource Allocation and Knowledge production: Studies in the Economics of University Research

UNU-MERIT Dissertation Series, № 18

1996

\section{Reinoud Joosten}

Dynamics, Equilibria, and Values UNU-MERIT Dissertation Series, № 17

\section{Hugo Kruiniger}

Investment, RED, and the Financing

Decisions of the Firm

UNU-MERIT Dissertation Series, № 16

\section{5}

\section{Hans van Meij1}

Endogenous Technological Change:

The Case of Information Technology,

Theoretical Considerations and

Empirical Results

UNU-MERIT Dissertation Series, № 15

\section{René Kemp}

Environmental Policy and Technical

Change: A Comparison of the

Technological Impact of Policy

Instruments

UNU-MERIT Dissertation Series, № 14

\section{Rohini Acharya}

The Impact of New Technologies on

Economic Growth and Trade: A Case

Study of Biotechnology

UNU-MERIT Dissertation Series, № 13

\section{Geert Duysters}

The Evolution of Complex Industrial Systems: The Dynamics of Major IT Sectors

UNU-MERIT Dissertation Series, № 12

\section{Marjan Groen}

Technology, Work and Organisation: A Study of the Nursing Process in Intensive Care Units

UNU-MERIT Dissertation Series, № 11

\section{4}

\section{Huub Meijers}

On the Diffusion of Technologies in a Vintage Framework: Theoretical Considerations and Empirical Results UNU-MERIT Dissertation Series, № 10 
Theon van Dijk

\section{2}

The Limits of Patent Protection: Essays on the Economics of Intellectual

Property Rights

UNU-MERIT Dissertation Series, № 9

\section{Hans Voordijk}

Naar Integrale Logistiek in

Bedrijfsketens: Ontwikkelingen in de Bouw

UNU-MERIT Dissertation Series, № 8

1993

\section{Paul Diederen}

Technological Progress in Enterprises and Diffusion of Innovation:

Theoretical Reflections and Empirical Evidence

UNU-MERIT Dissertation Series, № 7

\section{Ben Dankbaar}

Economic Crisis and Institutional

Change: The Crisis of Fordism from the Perspective of the Automobile Industry UNU-MERIT Dissertation Series, № 6

\section{Hanno Roberts}

Accountability and Responsibility: The Influence of Organisation Design on Management Accounting UNU-MERIT Dissertation Series, № 5

\section{Bart Verspagen}

Uneven Growth between

Interdependent Economies: An

Evolutionary View on Technology

Gaps, Trade and Growth

UNU-MERIT Dissertation Series,

№ 4

\section{Sjoerd Romme}

A Self-organization Perspective on

Strategy Formation

UNU-MERIT Dissertation Series, № 3

\section{9}

\section{John Spangenberg}

Economies of Scale, and Atmosphere in Research Organisations

UNU-MERIT Dissertation Series, № 2

\section{8}

\section{John Hagedoorn}

Evolutionary and Heterodox

Innovation Analysis: A Study of

Industrial and Technological

Development in Process Control and Information Technology

UNU-MERIT Dissertation Series, № 1 
